\title{
EFEITO DE NIVEIS CRESCENTES DE FARELO DE ALGODÃO E LISINA SOBRE A PERFORMANCE E CARACTERISTICAS DE CARCAÇA DE SUÍNOS EM CRESCIMENTO E ACABAMENTO
}

MARCIO POMPÉIA DE MOURA

Orientador: DR. ABEL LAVORENTI

Dissertação apresentada à Escola Superior de Agricultura "Luiz de Queiroz", da Universidade de São Paulo, para obtençāo do título de Mestre em Nutrição Animal e Pastagens.

PIR A C I C A B A

Estado de São Paulo - Brasil

Novembro de 1978 
DEDICO

A minha esposa

JANET I

pela compreensão e dedicação

Aos meus pais

LAERTE P INAH

pela constante dedicação

na minha formação 


\section{AGRADEC IMENTOS}

Ao Prof. Dr. ABEL LAVORENTI, pela dedicação e com preensão na condução do presente trabalho.

Ao Dr. CELSO BOIN, pelas constantes e brilhantes orientações em nossa iniciação científica dentro do Instituto de Zootecnia.

A minha esposa JANETI L. BOMBINI DE MOURA, pela colaboração na correção das referências.

Aos seguintes colegas e funcionários:

Eng: Agr: BENEDITO DO ESPIRITO SANTO DE CAMPOS

Med. Vet. FERNANDO GOMES CASTRO JR.

Zootec. ALTAIR VICENTE BRONDANI

Eng: Agr ${ }^{\circ}$ CARLOS ROBERTO VIOTTO MONTEIRO PACHECO

Eng: Agr $\because$ VALDOMIRO SHIGUERI MIYADA

Eng: Agr: RIMER RAMIZ TULLIO *

Eng: Agr ${ }^{\circ}$ EDGAR LEONE CAIELLI

Med. Vet. ANTONIO DE OLIVEIRA LOBÃO

Med. Vet. WALLACE NEWTON SCOTT

Eng: Agr $:$ DR. IRINEU UMBERTO PACKER

LUIZ CARLOS RODRIGUES

MIGUEL ANDRILLI

MARIZA APARECIDA DE MENESES

ADEMIR ADILSON GAZZETTA

Ao INSTITUTO DE ZOOTECNIA, pelas facilidades obtidas na condução dos dois ensaios e impressão do trabalho.

A PFIZER DO BRASIL, pelo fornecimento do premix mineral e vitaminico utilizado.

A HUMUS AGRICOLA S.A., pelas facilidades no fornecimento dos animais. 
Ao FRIGORIFICO ANGELELI.

As demais pessoas que colaboraram direta ou indiretamente com o presente trabalho. 
INDICE

Pāgina

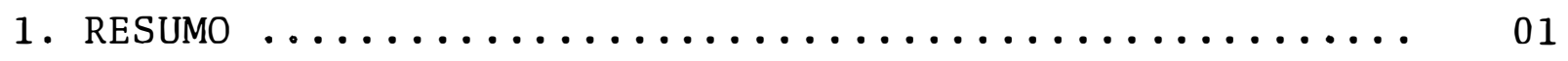

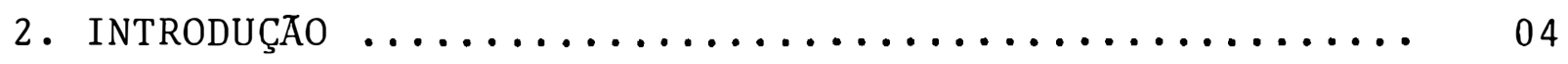

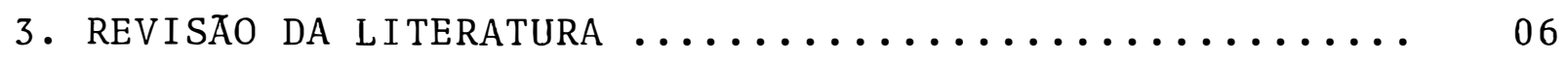

3.1. O farelo de algodão na alimentação de suínos .... 06

3.2. Gossipol, toxidez e prevenção .............. 10

3.3. Qualidade da proteína do farelo de algodão ...... 11

3.4. Importância da lisina na nutrição de suínos ..... 13

3.5. Efeito da Adição de lisina na qualidade das carca

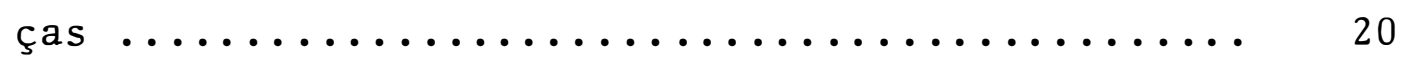

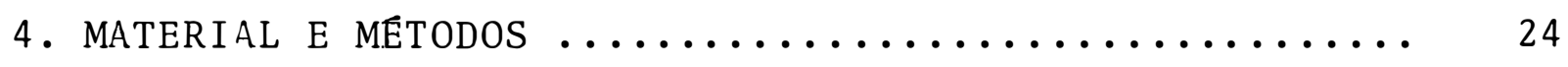

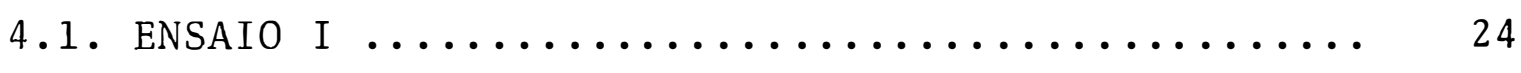

4.1.1. Local, material experimental e duração do

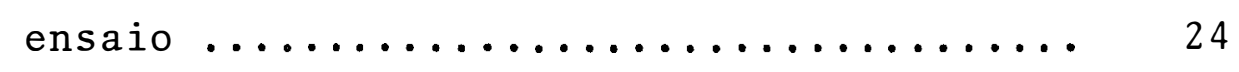

4.1.2. Manejo da alimentação, pesagens e amostra-

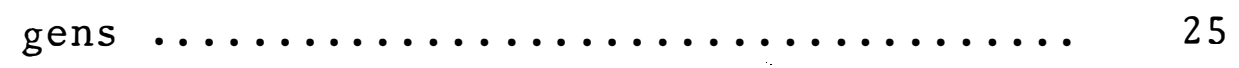

4.1.3. Rações experimentais ............... 25

4.1.4. Delineamento experimental ........... 28

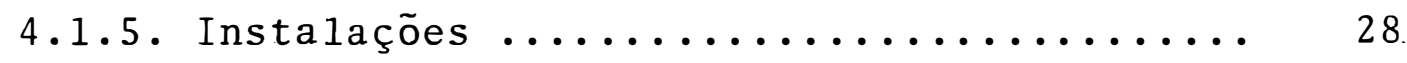

4.1.6. Classificação das carcaças ........... 31

4.2. ENSAIO II $\ldots \ldots \ldots \ldots \ldots \ldots \ldots \ldots \ldots \ldots \ldots \ldots \ldots \ldots \ldots \ldots \ldots \ldots \ldots \ldots$

4.2.1. Local, material experimental e duração do ensaio ........................... 31

4.2.2. Manejo da alimentação, pesagens e amostra gens ........................... 33

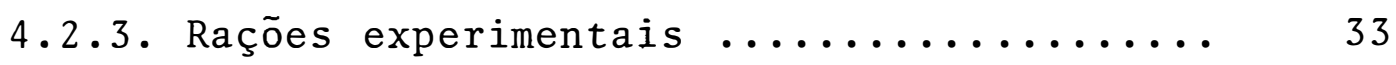

4.2.4. Delineamento experimental .......... 37

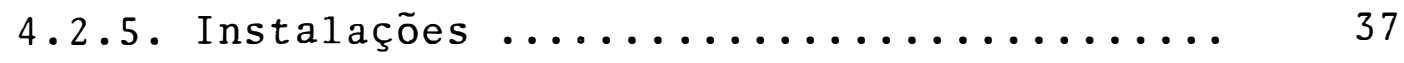

4.2.6. Classificação das carcaças .......... 38 


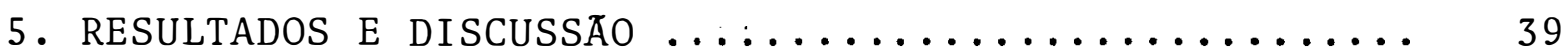

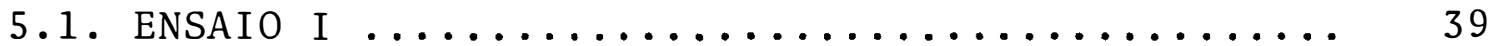

5.1 .1$. Ganho de peso .................. 39

5.1 .2 . Consumo de ração ................. 45

5.1 .3 . Conversão alimentar .............. 50

5.1 .4 . Qualidade das carcaças ............. 55

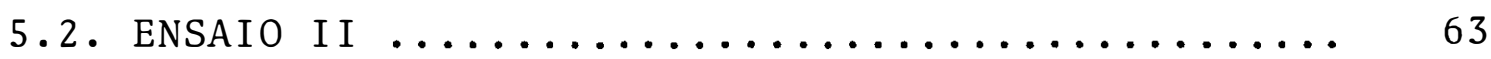

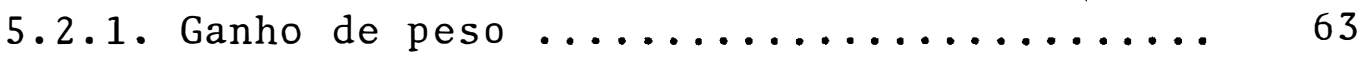

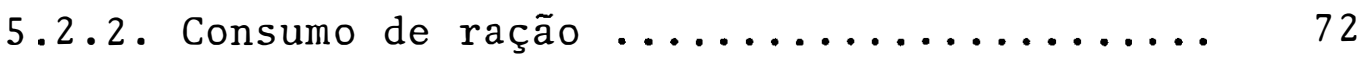

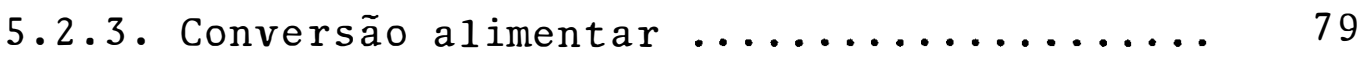

5.2 .4$. Qualidade das carcaças ............. 85

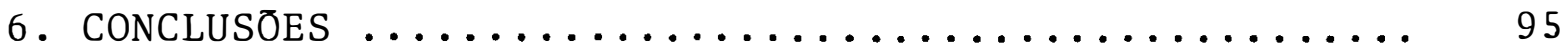

7. SUMMARY $\ldots \ldots \ldots \ldots \ldots \ldots \ldots \ldots \ldots \ldots \ldots \ldots \ldots \ldots \ldots \ldots \ldots$

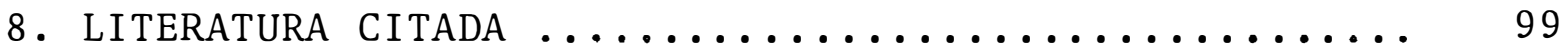

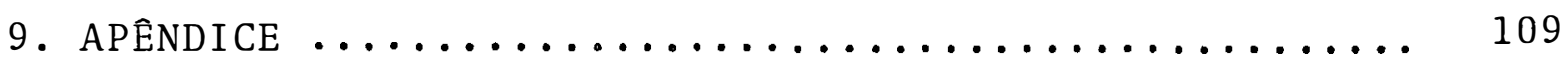


vii.

LISTA DE TABELAS

Página

TABELA 1. Anālise Bromatológica e Energia Metabolizável

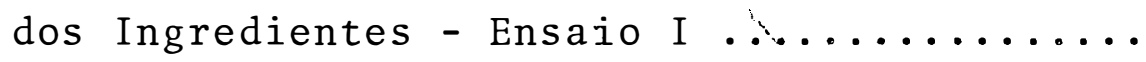

TABELA 2. Composição das Rações Experimentais - Período

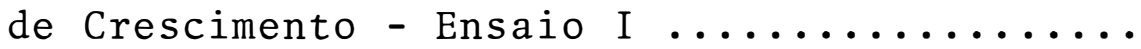

TABELA 3. Composição das Rações Experimentais - Período

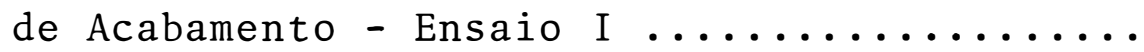

TABElA 4. Composição em Amino Âcidos do Farelo de Algo-

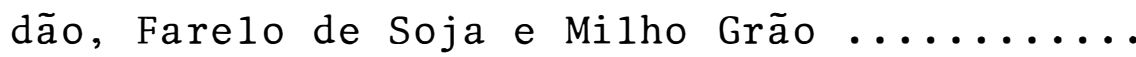

TABElA 5. Composição do Premix - Ensaio I e I I .......

TABELA 6. Anālise Bromatológica e Energia Metabolizável dos Ingredientes - Ensaio I I ...........

TABELA 7. Composição das Rações Experimentais - Período

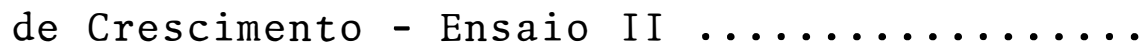

TABELA 8. Composição das Rações Experimentais - Período

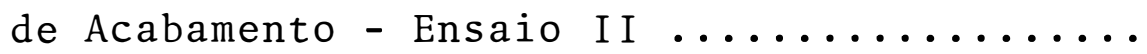

TABela 9. Ganho de Peso (kg) - Período Total (91 dias)-

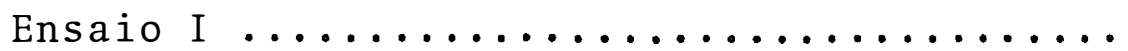

TABEla 10. Análise de Variância - Ganho de Peso - Perío-

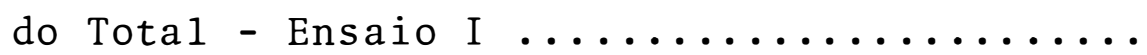

TABEla 11. Ganho de Peso (kg) - Período de Crescimento

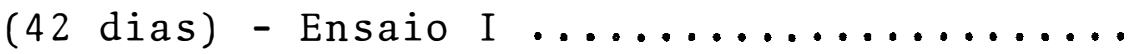

TABElA 12. Análise de Variância - Ganho de Peso - Período de Crescimento - Ensaio I ..............

TABElA 13. Ganho de Peso (kg) - Período de Acabamento

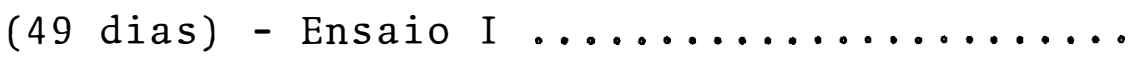

TABElA 14. Análise de Variância - Ganho de Peso - Perío-

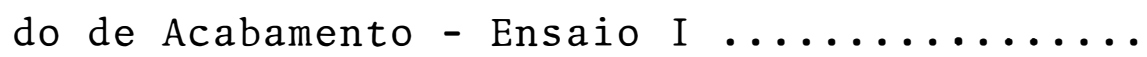


viiị.

Pāgina

TABElA 15. Consumo de Ração (kg) - Período Total (91 dias)

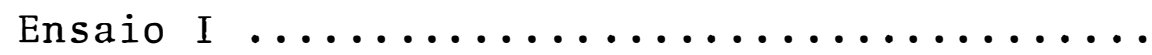

TABElA 16. Anālise de Variância - Consumo de Ração - Período Total - Ensaio I ................ 46

TABELA 17. Consumo de Ração (kg) - Período de Crescimento (42 dias) - Ensaio I ................

TABELA 18. Anālise de Variância - Consumo de Ração - Período de Crescimento - Ensaio I ..........

TABELA 19. Consumo de Ração (kg) - Período de Acabamento

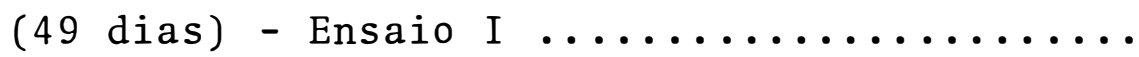

TABELA 20. Anālise de Variância - Consumo de Ração - Período de Acabamento - Ensaio I ............

TABELA 21. Conversão Alimentar - Período Total (91 dias)

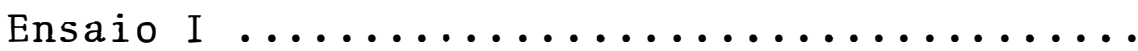

TABELA 22. Anāiise de Variância - Conversão Alimentar Período Total - Ensaio I ..............

TABELA 23. Conversão Alimentar - Período de Crescimento

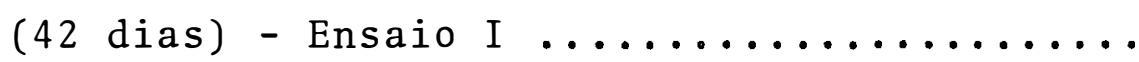

TABELA 24. Anālise de Variância - Conversão Alimentar Período de Crescimento - Ensaio I ..........

TABELA 25. Conversão Alimentar - Período de Acabamento (49 dias) - Ensaio I ..................

TABELA 26. Anālise de Variância - Conversão Alimentar Período de Acabamento - Ensaio I .......... 53

TABELA 27. Rendimento de Carcaça $\left(\begin{array}{l}0 \\ 0\end{array}\right)$ - Ensaio I ...... 56

TABELA 28. Anālise de Variância - Rendimento de Carcaça

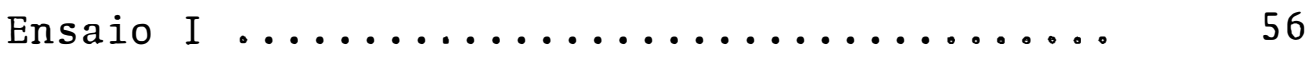

TABELA 29. Espessura do Toicinho (cm) - Ensaio I ..... 
TABELA 30. Anālise de Variância - Espessura do Toicinho -

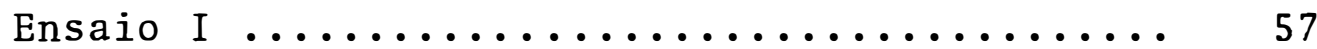

TABELA 31. Percentagem de Pernil - Ensaio I .......... 58

TABElA 32. Anālise de Variância - Percentagem de Pernil -

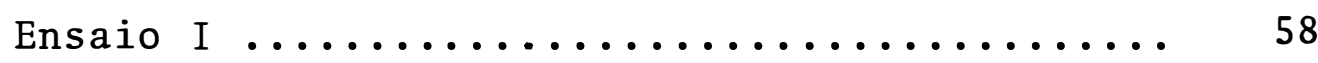

TABELA 33. Ārea do 01 ho de Lombo $\left(\mathrm{cm}^{2}\right)$ - Ensaio I ..... 60 TABELA 34. Anālise de Variância - Área do O1ho de Lombo -

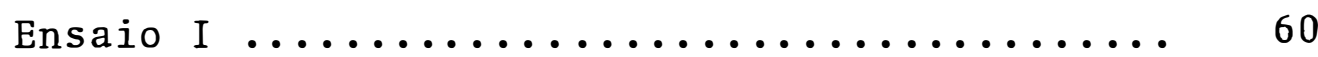

TABELA 35. Comprimento da Carcaça (cm) - Ensaio I ...... 61

TABELA 36. Anālise de Variância - Comprimento da CarcaçaEnsaio I .......................... 61

TABELA 37. Ganho de Peso (kg) - Período Total (91 dias) -

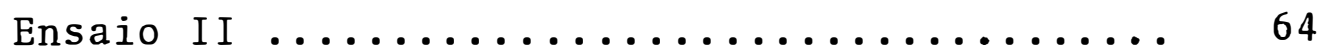

TABElA 38. Análise de Variância - Ganho de Peso - Período Total - Ensaio II .................... 64

TABElA 39. Ganho de Peso (kg) - Período de Crescimento

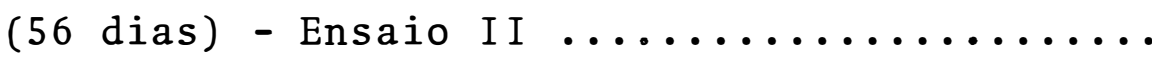

TABELA 40. Anālise de Variância - Ganho de Peso - Período de Crescimento - Ensaio II ................ 65

TABELA 41. Ganho de Peso (kg) - Período de Acabamento

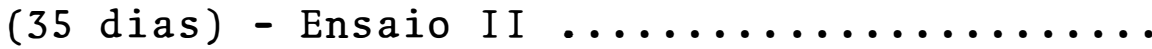

TABElA 42. Anālise de Variância - Ganho de Peso - Período de Acabamento - Ensaio II ................ 66

TABELA 43. Consumo de Ração (kg) - Período Iotal (91 dias)

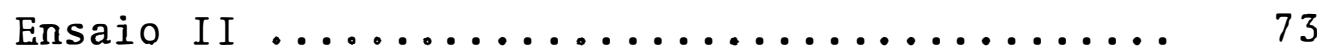

TABELA 44. Anālise de Variância - Consumo de Ração - Período Total - Ensaio I ................ 73 
TABElA 45. Consumo de Ração (kg) - Período de Crescimento

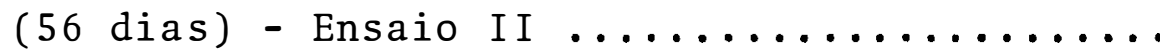

TABEla 46. Análise de Variância - Consumo de Ração - Período de Crescimento - Ensaio II ............

TABEla 47. Consumo de Ração (kg) - Período de Acabamento (35 dias) Ensaio I $\ldots \ldots \ldots \ldots \ldots \ldots \ldots \ldots \ldots$

TABElA 48. Anālise de Variância - Consumo de Ração - Pe-

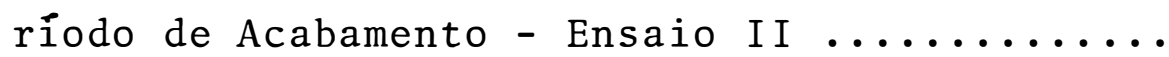

TABElA 49. Conversão Alimentar - Período Total (91 dias)-

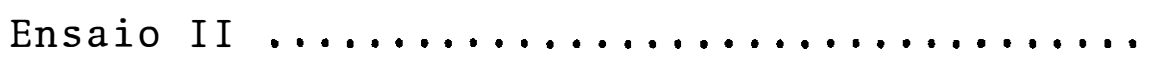

TABEla 50. Anālise de Variância - Conversão Alimentar -

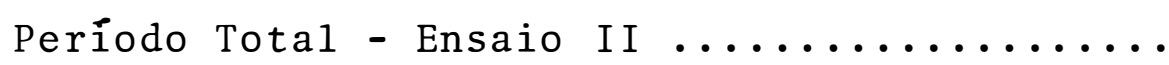

TABElA 51. Conversão Alimentar - Período de Crescimento -

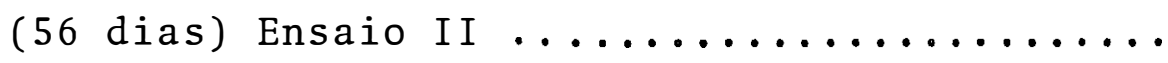

TABELA 52. Anālise de Variância - Conversão Alimentar Período de Crescimento - Ensaio II ...........

TABELA 53. Conversão Alimentar - Período de Acabamento

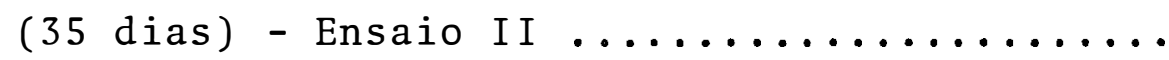

TABElA 54. Anālise de Variância - Conversão Alimentar Período de Acabamento - Ensaio II .......... 82

TABElA 55. Rendimento de Carcaça $\left(\frac{0}{0}\right)$ - Ensaio I ....... 83

TABELA 56. Anālise de Variância - Rendimento de Carcaça $\left(\begin{array}{l}0 \\ 0\end{array}\right)$ - Ensaio I I . . . . . . . . . . . . .

TABELA 57. Espessura do Toicinho (cm) - Ensaio II .....

TABElA 58. Análise de Variância - Espessura do Toicinho -

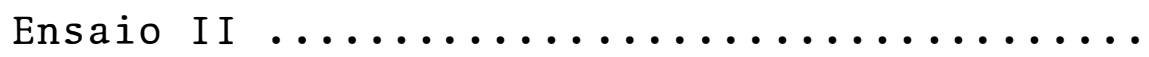

TABEla 59. Percentagem de Pernil - Ensaio II .......... 
$x i$

Página

TABEla 60. Análise de Variância - Percentagem do Pernil Ensaio II $\ldots \ldots \ldots \ldots \ldots \ldots \ldots \ldots \ldots \ldots \ldots \ldots \ldots \ldots$

TABELA 61. Área do 01 ho de Lombo $\left(\mathrm{cm}^{2}\right) \ldots \ldots \ldots . \ldots . . . . .90$

TABELA 62. Anālise de Variância - Ârea do 01ho de Lombo -

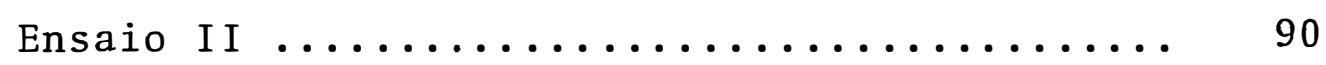

TABELA 63. Comprimento da Carcaça (cm) - Ensaio II ..... 91

TABELA 64. Análise de Variância - Comprimento da CarcaçaEnsaio II ......................... 91 
LISTA DE FIGURAS

Página

FIGURA 1. Efeito dos tratamentos sobre o ganho de peso durante o período total (91 dias) ..........

FIGURA 2. Efeito dos tratamentos sobre o ganho de peso durante o período de crescimento (42 dias).

FIGURA 3. Efeito dos tratamentos sobre a conversão alimentar durante o período total (91 dias) ....

FIGURA 4. Efeito dos tratamentos sobre a conversão alimentar durante o período de crescimento (42 dias) $\ldots \ldots \ldots \ldots \ldots \ldots \ldots \ldots \ldots \ldots \ldots \ldots \ldots \ldots \ldots \ldots \ldots \ldots$

FIGURA 5. Efeito dos tratamentos sobre a conversão alimentar durante o período de acabamento

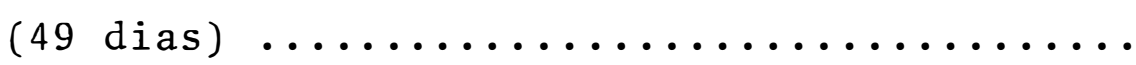

FIGURA 6. Efeito dos tratamentos sobre a espessura do

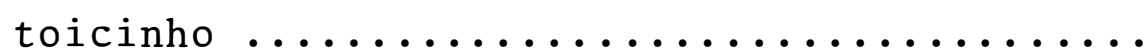

FIGURA 7. Efeito dos tratamentos sobre o pernil ......

FIGURA 8. Efeito dos tratamentos sobre a ārea do olho

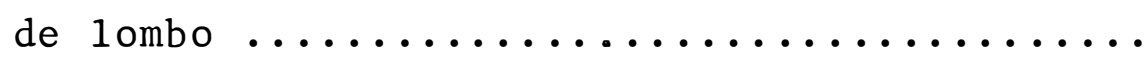

FIGURA 9. Efeito dos tratamentos ( 2,3 e 4) sobre o ganho de peso durante o período total (91 dias).

FIGURA 10. Efeito dos tratamentos (2, 3 e 4) sobre o ganho de peso durante a fase de crescimento

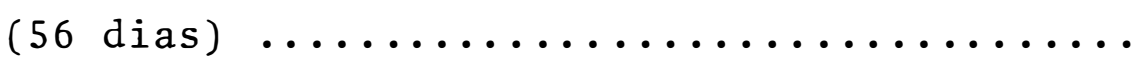

FIGURA 11. Efeito dos tratamentos (2, 3 e 4$)$ sobre o ganho de peso durante o período de acabamento

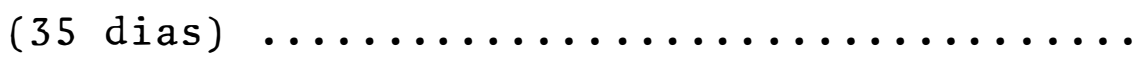


FIGURA 12. Efeito dos tratamentos ( 2,3 e 4 ) sobre o con sumo durante o período total (91 dias) ......

FIGURA 13. Efeito dos tratamentos ( 2,3 e 4 ) sobre o con sumo durante a fase de crescimento (56 dias).

FIGURA 14. Efeito dos tratamentos (2, 3 e 4) sobre o con sumo durante a fase de acabamento (35 dias).

FIGURA 15. Efeito dos tratamentos ( 5,6 e 7$)$ sobre o con sumo durante a fase de crescimento (56 dias).

FIGURA 16. Efeito dos tratamentos (2, 3 e 4 ) sobre a con versão alimentar durante o período total

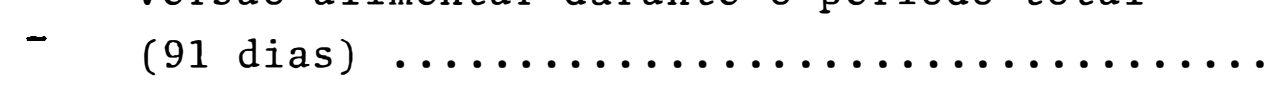

FIGURA 17. Efeito dos tratamentos (2, 3 e 4) sobre a con versão alimentar durante o período de cresci-

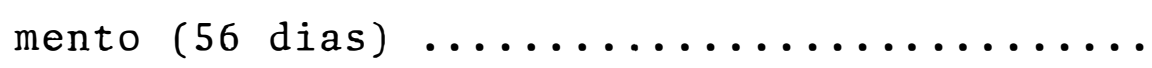

FIGURA 18. Efeito dos tratamentos (2, 3 e 4) sobre a con versão alimentar durante o período de acabamento ( 35 dias).$\ldots \ldots \ldots \ldots \ldots \ldots \ldots \ldots \ldots$

FIGURA 19. Efeito dos tratamentos( 2,3 e 4) sobre a área

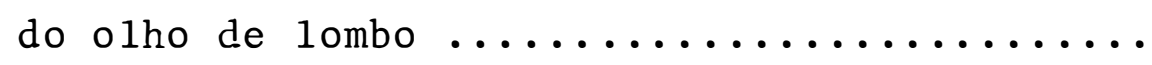

FIGURA 20. Efeito dos tratamentos (5, 6 e 7) sobre a área

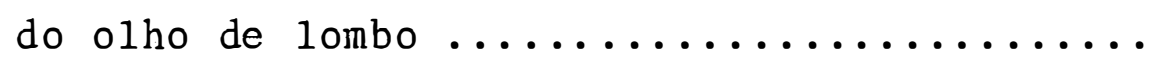


xiv.

APENDICE

Paǵina

TABELA $A_{1}$. Dados Metereológicos Observados D.urante o Pe-

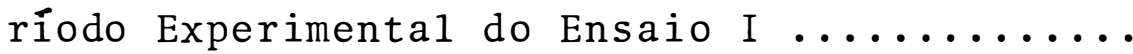

TABELA $\mathrm{A}_{2}$. Dados Metereológicos Observados Durante o Período Experimental do Ensaio II ...........

TABElA $\mathrm{A}_{3}$. Adição de Sulfato de Ferro - Ensaio I ...... 112

TABELA A 4 . Adição de Sulfato de Ferro - Ensaio II ..... 113

TABELA $A_{5}$. Pesos Individuais $(\mathrm{kg})$ dos Animais Durante o Período Experimental - Ensaio I ..........

TABElA $A_{6}$. Ganho de Peso Individual (kg) por Período de 14 dias - Ensaio I ...................

TABELA $A_{7}$. Consumo Individual ( $\mathrm{kg}$ ) por período de 14 dias

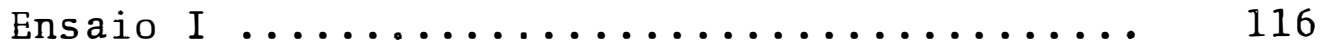

TABELA $A_{8}$. Conversão Alimentar Individual por Período de 14 dias - Ensaio I ..................

TABELA $A_{9}$. Dados Auxiliares para Obtenção das Carcaterís ticas de Carcaça Estudada - Ensaio I .......

TABELA $A_{10}$. Ganho de Peso Individual (kg) por Período de

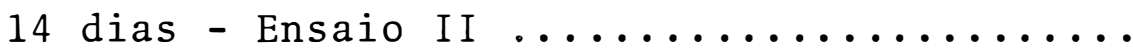

TABELA $A_{11}$. Pesos Individuais $(\mathrm{kg})$ dos Animais Durante o Período Experimental - Ensaio II ..........

TABElA $\mathrm{A}_{12}$. Consumo Individual ( $\mathrm{kg}$ ) por Período de 14 dias

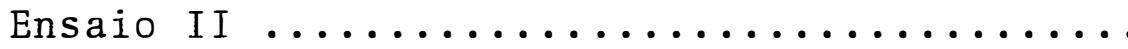

TABELA $A_{13}$. Conversão Alimentar Individual por Período de

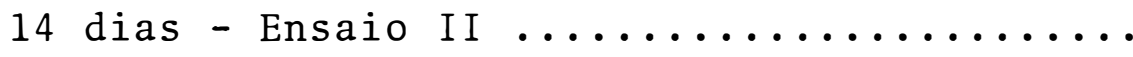

TABELA A ${ }_{14}$. Dados Auxiliares para Obtenção das Caracterís ticas de Carcaça Estudada - Ensaio II ....... 
NOME: MARCIO POMPEIA DE MOURA.

DATA DE NASCIMENTO: 08 de julho de 1944.

LOCAL DE NASCIMENTO: São Paulo - SP.

FORMAÇÃO UNIVERSITĀRIA: Engenheiro Agrônomo, formado em 1969, pela Escola Superior de Agricultura "Luiz de Queiróz" - USP - Piracicaba SP. - Brasil.

ATIVIDADE ATUAL: Pesquisador Científico - PqC 2 - Divisão de Nutrição Animal - Instituto de Zootecnia Nova Odessa - SP. 
1 - RESUMO

0 presente trabalho constou de 2 ensaios que objetivaram, o primeiro determinar até que nível percentual o fa relo de algodão poderia participar da ração de crescimento e acabamento para suínos sem causar efeitos negativos na performance ou na qualidade da carcaça e o segundo, estudou o efeito da adição de 0,2 e 0,4\% de 1isina a duas rações, uma tendo como fonte protéica apenas o farelo de algodão e a outra possuín do uma mistura de $75 \%$ de farelo de algodão e $25 \%$ de farelo de soja.

No Ensaio I foram utilizados 30 leitões machos castrados mestiços (Three Cross) das raças Large White $x$ Landrace $x$ Wessex.

0 delineamento estatístico utilizado foi o de blo cos ao acaso sendo os animais distribuídos de acordo com o peso em 6 blocos com 5 tratamentos, onde o farelo de algodão constituiu $0,25,50,75$ e $100 \%$ da fonte protéica respectivamente para os tratamentos $1,2,3,4$ e 5. 0 período experimental foi de 91 dias e os pesos médios inicial e final foram respectivamente 23,57 e $91,14 \mathrm{~kg}$. A ração e àgua foram fornecidas à vonta de.

As rações possuíam $16 \%$ de proteína bruta para o período de crescimento e 13\% para o período de acabamento. 
Após 91 dias de ensaio foi observado que: o aumen to de percentagem do farelo de algodão na ração durante o perío do total resultou em efeitos lineares para ganho de peso $(\mathrm{P}<0,05)$ e quadrático $(\mathrm{P}<0,05)$ para conversão alimentar, ambos negativos. $\mathrm{Na}$ anâlise da variância uma pior conversão foi observada para os tratamentos com maiores quantidades de farelo de algodão sendo o tratamento 5 significativamente inferior $(\mathrm{P}<0,05)$ aos demais.

As regressões não mostraram efeito significativo dos tratamentos sobre o rendimento e o comprimento da carcaça.

0 farelo de algodão causou no entanto efeito linear sobre a espessura do toicinho $(P<0,05)$, percentagem do per nil $(\mathrm{P}<0,01)$ e área do olho de lombo $(\mathrm{P}<0,01)$ prejudicando a qualidade da carcaça nas 3 características estudadas.

A percentagem de pernil no tratamento com $100 \%$ de farelo de algodão (tratamento 5) foi inferior aos demais $(\mathrm{P}<0,05)$ sendo que o tratamento 4 , com $75 \%$ de farelo de algodão não dife riu dos tratamentos 1 e 3 respectivamente com $0 \%$ e $50 \%$ de fare10 de algodão mas sim do tratamento 2 com $25^{\circ}(\mathrm{P}<0,05)$.

Quando o farelo de algodão representou $100 \%$ de fon te protéica (tratamento 5) houve efeito negativo sobre a ārea do olho de lombo sendo que este tratamento diferiu significativamen te dos demais $(P<0,05)$.

No Ensaio II foram utilizados 28 leitões machos cas trados mestiços (Three Cross) das raças Large White $x$ Landrace $x$ Wessex em um delineamento estatístico de blocos ao acaso distribuídos de acordo com o peso dos animais em 4 blocos com 7 tratamentos.

0 período experimental foi de 91 dias e os pesos médios iniciais e finais foram respectivamente 18,75 e $87,16 \mathrm{~kg}$. A forma de arraçoamento, pesagens, percentagens de proteína bruta das rações, foram semelhantes do Ensaio I.

Os tratamentos que tiveram como variâveis a fonte protêica, e o nível de lisina, foram os seguintes: $\mathrm{T}_{1}$ - farelode soja; $\mathrm{T}_{2}$ - farelo de algodão; $\mathrm{T}_{3}$ - farelo de algodão $+0,2 \%$ de 
lisina; $\mathrm{T}_{4}$ - farelo de algodão $+0,4 \%$ de lisina; $\mathrm{T}_{5}-75 \%$ de fa relo de algodão $+25 \%$ de farelo de soja; $\mathrm{T}_{6}-75 \%$ de farelo de algodão $+25 \%$ de farelo de soja $+0,2 \%$ de 1 isina; $\mathrm{T}_{7}-75^{\circ}$ de farelo de algodão $+25 \%$ de farelo de soja $+0,4 \%$ de lisina.

A adição de lisina resultou em efeito linear pos tivo $(\mathrm{P}<0,01)$ sobre o ganho de peso e consumo de ração nos tratamentos contendo farelo de algodão como única fonte proteíca, sendo que para a conversão alimentar o efeito foi quadrático $(\mathrm{P}<0,05)$ positivo.

A adição de $0,4 \%$ de lisina na ração resultou em desempenho superior de ganho de peso que a adição de $0,2 \%$, sendo este tratamento melhor do que o tratamento sem adição de ami no ácido. Para conversão alimentar e consumo de ração com $0,2 \%$ e $0,4 \%$ não diferiram significativamente entre si mas superaram significativamente $(P<0,05)$ o tratamento 2 sem adição de lisina. Quando a fonte protéica foi constituída de $75^{\circ}$ de farelo de algodão e $25 \%$ de farelo de soja, a adição de $0,2 \%$ de lisina (tratamento 6) melhorou o consumo $(P<0,05)$. A adição de $0,4 \%$ de lisina melhorou a conversão alimentar $(\mathrm{P}<0,05)$ em relação ao tratamento sem adição de lisina (tratamento 5).

Entre as características de carcaça estudadas, so mente a ärea do olho de lombo mostrou um efeito linear positivo significativo $(P<0,05)$ devido a adição de lisina, sendo que as médias da área do olho de lombo dos tratamentos com $0,2 \%$ e $0,4 \%$ de lisina adicional foram maiores significativamente $\quad(P<0,05)$ que a mêdia do tratamento 5 sem adição de lisina, mas não foram diferentes entre si.

Dentro das condições do presente trabalho os resultados dos 2 ensaios indicaram que o farelo de algodão como fonte exclusiva de proteína para suínos em crescimento e acabamento deve ser suplementada com $0,4 \%$ de lisina, podendo ainda constituir $75^{\circ}$ da fonte protéica sendo a suplementação neste ca so de $0,2 \%$ de lisina. 


\section{INTRODUÇÃO}

A extração de óleo de sementes de oleaginosas dá origem a subprodutos que são largamente utilizados na alimenta ção animal. O farelo de algodão é um desses subprodutos e como fonte protéica é amplamente utilizado principalmente para poli gástricos.

Seu emprego na alimentação de monogástricos tem sido limitado por diversos fatores, entre os quais a presença de gossipol e o seu baixo teor em lisina.

Alguns estudos tem procurado corrigir as limitações acima mencionadas visando a utilização do farelo de algodão.

0 presente estudo teve por objetivo obter novas informações sobre a utilização do farelo de algodão na alimentação de suínos no Brasil, em razão da menor cotação desta fon te protéica no mercado em relação a do farelo de soja, que é o alimento usualmente empregado em rações para suínos.

No momento atual que a tendência no campo da nutrição animal é substituir a idéia de exigência em proteína por exigência em amino ácidos, e com os estudos da suplementação de fontes protéicas com amino ácidos sintéticos, os resultados positivos já obtidos tem permitido uma maior utilização daqueles amino ácidos sintéticos em rações de monogástricos. Assim 
sendo a viabilidade da utilização de amino ácidos rotineiramen te, torna-se cada vez maior em razão do seu menor custo devido a maior demanda.

No presente trabalho o ensaio I visou determinar o nível de farelo de algodão na ração que permitisse um bom de sempenho dos animais, sendo que o ensaio II teve como objetivo corrigir através de adição de lisina os tratamentos do ensaio I, que apresentaram aspectos negativos com relação ao desempe nho dos animais, bem como com relação as características de car caça. 
3. REVISAOO DE LITERATURA

3.1. Farelo de algodão na alimentação de suínos

O farelo de algodão vem sendo utilizado na alimentação de suínos desde o século passado - CURTIS e CARSON (1892) - in HALE et alii (1958). O farelo era utilizado em mis tura com uma fonte protéica de origem animal, sendo neste caso, superior à tancagem - NATIONAL COTTONSEED PRODUCTS ASSOCIATION, $1950-$.

A utilização de farelo de algodão como fonte de proteína para os suínos trouxe, há algumas décadas atrás,resul tados desastrosos (HALE et alii, (1958), motivando o desenvolví mento de estudos de seu valor nutritivo, bem como da correção de suas falhas, visando o seu emprego não só na alimentação animal como na alimentação humana.

CARROL et alii. (1962), mencionaram os ótimos re sultados obtidos na alimentação de suínos com rações possuíndo como fonte protéica o farelo de algodão misturado a uma fonte de proteína de origem animal, como a farinha de peixe, ou de origem vegetal, como o farelo de soja.

CUNHA et ali.i (1974), como a maioria dos autores, considera a proteína do farelo de soja como sendo de alta qualidade, podendo a mesma ser fornecida como fonte protéica exclusiva, em rações para suínos durante as fases de crescimento e aca 
bamento. O mesmo autor realça que rações para suínos em crescimento e acabamento constituída de $50 \%$ de farelo de algodão e $50 \%$ de farelo de soja, apresentaram bons resultados.

Diversos autores, entre os quais WALLACE et alii. (1955), DYER et alii (1952), AGUIRRE et alii (1960), BELL e LAR SEN (1967), NOLAND (1968), MONCADA e MANER (1970) e OBANDO et alii (1975), realizaram estudos com farelo de algodão comparando-o com o farelo de soja, como fonte protéica para suínos.

WALLACE et alii (1955) estudaram o uso dos farelos de algodão e de soja, em vários ensaios com suínos. No primeiro, utilizaram farelo de algodão, obtido pelo processo de ex tração de óleo por solvente, e farelo de soja obtendo, respectí vamente, os seguintes resultados para as duas fontes protéicas: ganho diário de peso - 0,104 e 0,617kg, consumo diário de ração - 0,803 e $2,270 \mathrm{~kg}$ e conversão alimentar - 7,57 e 3,58. No se gundo, alimentaram 20 animais dos 23,8 aos $44,0 \mathrm{~kg}$ de peso vivo com ração contendo farelo de soja ou mistura de $50 \%$ de farelo de soja mais $50 \%$ de farelo de algodão, como fontes de proteína. 0 ganho diário de peso dos animais no primeiro tratamento foi de $0,807 \mathrm{~kg}$ e no segundo $0,744 \mathrm{~kg}$, sendo a diferença estatísticamente significativa $(P<0,05)$. Os consumos diários de ração $(4,84$ e $5,45 \mathrm{~kg})$ e as conversões alimentares $(2,95$ e 3,07) não diferiram estatísticamente.

SEWELL et alii (1957) observaram que pelo menos metade do farelo de soja pode ser substituído, satisfatoriamente, por farelo de algodão, como fonte de proteína em rações de crescimento para suínos, tanto em regime confinado como em pastagens. Semelhante conclusão foi obtida por HAINES et alii (1957), que realizaram um ensaio compondo rações com várias combinações de farelo de soja e farelo de algodão (processo solvente degossipolizado), para leitões desmamados. A ração mais eficiente foi aquela contendo $50 \%$ de farelo de algodão degossipolizado e $50 \%$ de farelo de soja.

Em um ensaio em que foi efetuada a substituição 
do farelo de gergelim por farelo de algodão, BRAHAM et alii (1962) obtiveram os seguintes resultados para ganho diário de peso e conversão alimentar: $0,490 \mathrm{~kg}$ e 3,$18 ; 0,490 \mathrm{~kg}$ e 3,$85 ; 0,500 \mathrm{~kg}$ e 3,08; $510 \mathrm{~kg} \mathrm{e} 3,00 ; 0,190 \mathrm{~kg}$ e 4,84 , respectivamente para $0,5,10,15$ e $20 \%$ de farelo de algodão na ração.

GONZALES e AGUILLERA (1967) estudaram a performance de suinos em crescimento, submetidos a 4 tratamentos com as seguintes fontes de proteína: $\mathrm{T}_{1}$ - farelo de algodão, $\mathrm{T}_{2}$ - farelo de algodão mais farelo de soja, $\mathrm{T}_{3}$ - farelo de algodão mais farinha de peixe e $\mathrm{T}_{4}$ - farelo de soja. Em todos os tratamentos o milho moido foi a fonte energética. Os resultados de ganho de peso, conversão alimentar e consumo de ração, durante os 79 dias do período experimental, foram: $42,2 \mathrm{~kg}, 3,60$ e $153,4 \mathrm{~kg} ; 47,8 \mathrm{~kg}$, 3,26 e $156,2 \mathrm{~kg} ; 50,7 \mathrm{~kg}, 3,31$ e $168,2 \mathrm{~kg} ; 51,7 \mathrm{~kg}, 3,00$ e $154,9 \mathrm{~kg}$, respectivamente para os tratamentos $\mathrm{T}_{1}, \mathrm{~T}_{2}, \mathrm{~T}_{3}$ e $\mathrm{T}_{4}$, mostrando que as rações tendo farelo de soja mais farelo de algodão não apresentaram resultados satisfatórios, os quais foram ainda pio res, quando os animais receberam como fonte protéica somente o farelo de algodão.

JARQUIN et alii (1968) demonstraram que o farelo de soja foi mais eficiente que o farelo de algodão, proporcionado melhores ganhos de peso e conversão alimentar, a suínos em fase de crescimento e acabamento. A mesma eficiência foi observada por MAIA (1969) que, ao fornecer para leitões rações com $100 \%$ de farelo de soja, conseguiu resultados significativamente superiores aos do tratamento com $100 \%$ de farelo de algodão, tan to para ganho de peso como para conversão alimentar.

OSTROWSKI et alii. (1969) submeteram animais em acabamento a cinco tratamentos, contendo níveis crescentes de substituição do farelo de soja por farelo de algodão(0, 25, 50, 75 e $100 \%$ ) alèm de aumentos simultâneos do teor de farinha de peixe nas rações. Os melhores resultados para ganho de peso e conversão alimentar, foram obtidos com os níveis de $50 \%$ e $75 \%$ de substituição, sendo que para $25 \%$ e $100 \%$ houve um pior desempe- 
nho dos animais.

MONCADA e MANER (1970) utilizaram 35 suínos durante 91 dias, distribuídos em 7 diferentes tratamentos, sendo nos 4 primeiros efetuada substituição do farelo de soja pelo farelo de algodão em níveis crescentes $(0 ; 3,53 ; 7,32$ e $11,41 \%)$ e os 3 restantes possuíam níveis de 20,30 e $40 \%$ de farelo de algodão, mantendo constante $3,81 \%$ de farelo de soja. Os resultados dos sete tratamentos para ganho diário de peso, consumo diārio de ração e conversão alimentar foram: $0,756 \mathrm{~kg}, 2,67 \mathrm{~kg}$ e 3,$54 ; 0,842 \mathrm{~kg}, 3,07 \mathrm{~kg}$ e 3,$65 ; 0,833 \mathrm{~kg}, 3,00 \mathrm{~kg}$ e 3,$59 ; 0,829 \mathrm{~kg}$, $2,98 \mathrm{~kg}$ e 3,$50 ; 0,522 \mathrm{~kg}, 2,03 \mathrm{~kg}$ e 3,$89 ; 0,550 \mathrm{~kg}, 2,29 \mathrm{~kg}$ e 4,16 ; $0,288 \mathrm{~kg}, 1,37 \mathrm{~kg}$ e 9,52 respectivamente para os níveis de 0 ; 3,$53 ; 7,32 ; 11,41 ; 20,00 ; 30,00$ e 40,00\% de farelo de algodão na ração.

No Brasil, RODRIGUES (1972) utilizou 24 suínos durante os períodos de crescimento e acabamento. o ensaio cons tou de três tratamentos, onde o farelo de soja foi substituído pelo farelo de algodão em níveis de 0,50 e $100 \%$. Os resultados para ganho diário de peso, consumo diārio de ração e conversão alimentar foram: $0,772 \mathrm{~kg}, 2,711 \mathrm{~kg}, 3,48 ; 0,798 \mathrm{~kg}, 2,664 \mathrm{~kg}$, 3,32 e $0,842 \mathrm{~kg}, 2,807 \mathrm{~kg}$ e 3,41 , respectivamente para os tratamentos com 0,50 e $100 \%$ de farelo de algodão, não havendo nenhuma diferença estatísticamente significativa para as caracte rísticas mencionadas.

Mais recentemente VIANA et alii (1976) realizaram um ensaio com suínos durante 124 dias, com 4 tratamentos: $\mathrm{T}_{1}$ - ração controle; $\mathrm{T}_{2}$ - substituição de 12,5\% de uma mistura de farelo de soja e farelo de trigo por $12,5 \%$ de farelo de algodão; $\mathrm{T}_{3}$ - substituição de $15 \%$ da mistura farelo de soja e fá relo de trigo por $15 \%$ de farelo de algodão e $\mathrm{T}_{4}$ - substituição de $17,5 \%$ da mistura do farelo de soja e farelo de trigo por $17,5 \%$ de farelo de algodão. Ao farelo de algodão adicionou-se 2,5\% de sulfato ferroso. Os ganhos de peso e as conversões alimentares foram: $87,08 \mathrm{~kg}$ e $3,92,78,83 \mathrm{~kg}$ e $4,34,74,92 \mathrm{~kg}$ e $4,48,66,33 \mathrm{~kg}$ 
e 4,68 respectivamente, para os tratamentos $\mathrm{T}_{1}, \mathrm{~T}_{2}, \mathrm{~T}_{3}$ e $\mathrm{T}_{4}$, sendo observado a redução para ganho de peso bem como um efeito negativo sobre a conversão alimentar, em função do aumento do teor de farelo de algodão na ração.

\subsection{Gossipol - Toxidez e prevenção}

Por muitos anos o gossipol contido no farelo de algodão foi responsável pela limitada utilização desta fonte protéica na alimentação de suínos - (WALLACE et alii, 1955), sen do que HOLLEY et alii (1955) mencionaram que rações contendo mais de $0,01^{\circ}$ de gossipol livre são tóxicas para suínos.

HALE et alii (1958) citam vários autores, como CURTIS e CARSON (1892), BURTIS (1895), DINWIDDIE (1903) que rea lizaram trabalhos com suínos utilizando o farelo de algodão co mo fonte protéica, ocasionando a morte de muitos animais com sintomas de intoxicação por gossipol.

Mais tarde, SMITH (1957) realizou um estudo qua se completo a respeito da patologia dos animais intoxicados Utilizou 18 animais, que morreram ao consumir rações com $0,03 \%$ de gossipol livre. O mesmo autor mencionou as principais lesoẽs patológicas e outras alterações devido a intoxicação por inges tão de gossipol: dispnéia, respiração ofegante, congestão e ede ma pulmonar, congestão do fígado, despigmentação e pele seca e quebradiça.

o gossipol é um pigmento, solúvel em óleo existente no caroço do algodão. Reage com anilina formando o diani logossipol, insolúvel em solventes orgânicos usuais. E um alca lóide polifenólico de cor amarela cuja fórmula é $\mathrm{C}_{30} \mathrm{H}_{30}{ }_{8}$ (BAR BOSA , 1969)。

Muitos esforços têm sido empregados com o objetivo de minimizar o efeito tóxico do gossipol, tais como, desenvolvimento de variedades de algodão com baixo teor de gossi pol, tratamentos durante o processamento do farelo de algodão, 
bem como, a adição de produtos químicos que combinem com o gos sipol e diminuam sua concentração no farelo (BUITRAGO et alii, 1977) •

Um grande nümero de pesquisadores tem procurado estudar a prevenção da intoxicação por gossipol utilizando prọ dutos químicos.

WINTHERS (1917) e GALLUP e REDER (1928) in SMITH e CLAWSON (1965) iniciaram estudos utilizando sais de ferro. Posteriormente STEVENSON et alii (1965) trabalhando com seis sais de ferro, observou que o sulfato e o fumarato de ferro fo ram os mais eficientes, prevenindo totalmente a mortalidade por intoxicação, dos animais que receberam farelo de algodão trata do. Entre os animais submetidos ao tratamento com farelo de a 1 godão sem adição de nenhum tipo de sal de ferro, a mortalidade foi de $50 \%$.

Diversos autores, entre eles CLAWSON et alii, (1961), BRAHAM et alii. (1962) e BUITRAGO et alii. (1970), indicam o sulfato de ferro como um eficiente protetor na prevenção contra o gossipol.

Estudando o nível de adição de sulfato de ferro, BARRENTINE (1966) conseguiu uma eficiente proteção concluíndo que, com a adição de $0,25 \%$ do sal na ração, os efeitos tóxicos do gossipol foram anulados. Do mesmo modo MONCADA e MANER (1970) adicionaram $0,25 \%$ de sulfato de ferro a rações com diferentes porcentagens de farelo de algodão, e concluíram que os efeitos tóxicos do gossipol foram neutralizados.

ESMINGER (1970) recomenda, quando o nível de gos sipol livre da ração for maior que $0,01 \%$, a adição de sulfato de ferro, na base de $1: 1$, isto é $1 \mathrm{ppm}$ de ferro para cada ppm de gossipol livre, até o máximo de 500 ppm de ferro.

\subsection{Qualidade da proteína do farelo de algodão}


mos de qualidade de proteína, pode ser considerado como razoávelmente bom, pois apresenta boa composição em aminoácidos essenciais,possuíndo níveis de arginina e metionina superiores aos do farelo de soja, segundo PHELPS (1966).

HALE et alii (1958) consideraram o farelo de a 1 godão como uma fonte boa de triptofano, regular de metionina e deficiente de lisina, sendo este último o aminoäcido limitante na sua utilização.

PHELPS (1966) afirmou que a qualidade da proteí na do farelo de algodão, depende em grande parte do processo que é utilizado na extração do óleo, sendo usuais 3 métodos, à saber: prensagem, solvente e prē-prensagem solvente.

De acordo com BALIGA e LYMAN (1957), a elevação da temperatura durante o processamento do farelo de algodão, induz a formação de um complexo proteína - gossipol, piorando o valor nutritivo do farelo, sendo que a ligação do gossipol e proteína é feito por um grupo amino. Por outro lado TANKSLEY (1970) bem como POND e MANER (1974) mencionaram que a temperatura excessiva durante o processamento do farelo de algodão,po de dar origem a ligação de carboidratos com o grupo amino epsi lon da lisina. Assim sendo, o farelo de algodão submetido a temperatura excessiva terá sua disponibilidade de lisina grandemente diminuída, apesar da diminuição do teor de gossipol 1i vre.

BRESSANI et a1ii. (1968) determinaram a composição química do farelo de algodão proveniente dos três processos de extração do óleo, obtendo os seguintes resultados: proteína bruta; 42,1; 47,6 e 35,8\%; extrato etéreo; 6,9; 2,9 e 2,5\%; gossipol 1ivre; 0,$051 ; 0,056$ e 0,125\% e 1isina: 293, 292 e $350 \mathrm{mg} / \mathrm{g}$ de $\mathrm{N}$, respectivamente, para os processos de prensagem, pré-prensagem solvente e solvente. Já BUITRAGO et alii. (1977), apresentaram dadọs de composição de farelo de algodão provenientes de várias regiões e de várias espécies de gênero Gossypium. Os autores forneceram os dados de composição química média de farelo de algodão, combinando as origens e as espé 
cies botânicas com os processos de extração do óleo. Os resultados foram os seguintes: proteína bruta; 41,0, 41,4 e 41,4\%; extrato etéreo; $3,72,0,58$ e $1,51 \%$; gossipol livre;0,04, 0,05 e $0,30 \%$ e lisina; $1,59,1,71$ e $1,76 \%$ respectivamente para os pro cessos de prensagem, pré-prensagem solvente e solvente.Segundo os mesmos autores, de maneira geral, é possível afirmar que o farelo de algodão proveniente da extração de óleo pelo processo solvente, é de melhor qualidade, mas segundo POND e MANER (1974), o grande incoveniente desse tipo de farelo é seu alto teor de gossipol. Assim sendo é mais recomendável a utilização do processo pré-prensagem solvente, que dá origem a um farelo com baixo teor de gossipol e com proteína de qualidade média para boa. Mencionaram ainda os autores, que o farelo obtido por prensagem, apresenta baixo conteúdo de gossipol, mas sua proteína é de má qualidade.

\subsection{Importância da lisina na nutrição dos suínos,}

Os aminoácidos são unidades estruturais da pro teína. Os primeiros estudos referentes a aminoácidos em nutrição animal datam de 1905, quando KAUFFMAN in MAYNARD e LOOSLI (1966), reconheceu que o triptofano e a cistina eram necessârios na nutrição protéica do cão como suplementos da gelatina. Estes estudos foram precursores do atual conceito do papel essencial dos aminoácidos em nutrição animal. Grande importância deve ser dada ao balanceamento correto dos aminoácidos em uma ração para suínos.

Segundo POND e MANER (1974), entre os 10 aminoácidos essenciais, dois se destacam devido sua deficiência nas rações usuais para suínos, a lisina e o triptofano.

Os trabalhos realizados por MERTz et alii (1949) indicaram ser a lisina um aminoácido indispensável no crescimento e desenvolvimento de leitões desmamados, sendo sua impor tância confirmada por MEADE (1956) que adicionou lisina a uma 
ração baseada em milho e farelo de soja para leitões, conseguin do substancial aumento na retenção de nitrogênio.

Diversos autores trabalharam na determinação das exigências de lisina para suínos, entre eles SHELTON et alii (1951), HUTCHINSON et alii (1957), GERMANN et alii (1958), sendo que os últimos observaram que a exigência de leitões lactentes era $0,70 \%$ de 1 isina na ração.

MC WARD et alii. (1959) conduziram 3 ensaios com anịnais com peso inicial de $13,6 \mathrm{~kg}$ com duração de 28 dias cada um. Os au tores constataram que a exigência de lisina variou de acordo com o nível de proteína da ração. Na ração com 12,8\% de proteína bru ta a exigência de lisina foi de $0,71 \%$, enquanto que para os an $\underline{i}$ mais que receberam a ração com $21,7 \%$ de proteína bruta, a exigência foi de $0,95 \%$.

BRAUDE (1960) mostrou que a adição de $0,2 \%$ de $1 \underline{i}$ sina mais $0,1 \%$ de metionina a uma ração para suínos, composta de $75 \%$ de cevada, 23\% de trigo, 1,5\% de calcário e 0,5\% de sal mais vitaminas A e D, melhorou significativamente o ganho diārio de peso de 0,599 para $0,662 \mathrm{~kg}(P<0,01)$ e a conversão alimen tar de 3,35 para $3,10(P<0,01)$ durante as fases de crescimento e acabamento.

Igualmente CLAWSON et alii (1961) obtiveram um eíeito positivo para ganho de peso, consumo e conversão alimentar, quando adicionaram $0,2 \%$ de 1 isina a uma ração tendo como fonte protéica o farelo de algodão com baixo teor de gossipol, para suínos em crescimento e acabamento.

Do mesmo modo HALE e LYMAN (1961) fizeram adição de 6 níveis de lisina a uma ração baseada em grão de sorgo e fa relo de algodão, para suínos em crescimento e acabamento. Os re sultados para ganho diário de peso e conversão alimentar foram: $0,599 \mathrm{~kg}$ e 4,$07 ; 0,644 \mathrm{~kg}$ e 3,$64 ; 0,684 \mathrm{~kg}$ e 3,$75 ; 0,708 \mathrm{~kg}$ e 3,77; $0,717 \mathrm{~kg}$ e 3,$79 ; 0,730 \mathrm{~kg}$ e 3,57 respectivamente para os níveis de $0 ; 0,1 ; 0,2 ; 0,3 ; 0,4 ; 0,5 \%$ de adição de 1 isina. As diferenças foram estatisticamente significativas para ganho de peso $(P<0,05)$ e para conversão alimentar $(P<0,01)$ entre os níveis es tudados de adição de lisina. 
MAGRUDER et alii (1961) realizaram um estudo su plementando com lisina, rações de baixo ou de alto teor de pró teína para suínos em crescimento e acabamento. Em um primeiro ensaio foram utilizadas rações contendo níveis de 14 e $12 \%$ ou $11 \%$ e $9 \%$ de proteína bruta nas fases de crescimento e acabamen to respectivamente, com ou sem adição de $0,1 \%$ de 1 isina, totalizando 4 tratamentos. Os resultados obtidos para ganho diário de peso e conversão alimentar foram: $0,689 \mathrm{~kg}$ e 3,$74 ; 0,698 \mathrm{~kg}$ e 3,$75 ; 0,580 \mathrm{~kg}$ e 4,$11 ; 0,499 \mathrm{~kg}$ e 4,52 respectivamente para os níveis 14 e $12 \%$ de proteína bruta com e sem lisina e 11 e $9 \%$ de proteína bruta com e sem lisina. Os resultados para ganhode peso diferiram significativamente $(P<0,05)$ para nível de prote $\underline{i}$ na. A lisina teve efeito sobre o ganho de peso somente para 0 nível de 11 e 9\% de proteína bruta. Em um segundo ensaio semelhante ao anterior, os níveis de proteína bruta da ração foram 14 e $12 \%$ e 12,5 e $10,5 \%$ nas fases de crescimento e acabamento respectivamente. Os seguintes resultados foram observados para ganho diārio de peso e conversão alimentar: $0,653 \mathrm{~kg}$ e 3,20; $0,649 \mathrm{~kg}$ e 3,$49 ; 0,562 \mathrm{~kg}$ e 3,$65 ; 0,621 \mathrm{~kg}$ e 3,22 respectivamente para os níveis de 14 e $12 \%$ com e sem lisina e 12,5 e $10,5^{\circ}$ corl e sem lisina.

DAVIDSON (1962) utilizou 104 animais "three cross" para estudar o efeito da adição de lisina, a uma ração composta de cevada e farelo de soja fornecida a suínos em cres cimento e acabamento, tendo obtido os seguintes resultados para ganho diário de peso e conversão alimentar: 0,971kg e 3,19; $0,862 \mathrm{~kg}$ e 3,$32 ; 1,011 \mathrm{~kg}$ e 3,14 e $0,998 \mathrm{~kg}$ e 3,05 , respectivamente para os níveis $0 ; 0,1 ; 0,2$ e $0,3 \%$ de adição de lisina.

Por outro lado SEWELL e PRICE (1962)adicionaram $0,05 \%$ e $0,1 \%$ de 1 isina a duas rações de $12 \%$ de proteína bruta com baixo ou alto nível de energia, constituída de milho e farelo de soja. A adição não resultou em melhores ganhos de peso durante o período de acabamento, tanto para a ração de baixa como para a de alta energia. 
BELL e LARSEN (1963) estudando o efeito da adição de lisina ou farinha de peixe à rações tendo o farelo de algodão como fonte protéica, observaram que apesar dos resulta dos não serem estatísticamente significativas, houve uma melho ra para ganho de peso quando foi adicionado lisina ou farinha de peixe. Os ganhos diários de peso foram de 0,$744 ; 0,798 ; 0,789 \mathrm{~kg}^{\prime}$

e $0,789 \mathrm{~kg}$ respectivamente para ração controle, controle mais $0,1 \%$ de lisina, controle mais $1,5 \%$ de farelo de peixe e controle mais $1,5 \%$ de farelo de peixe mais $0,05^{\circ}$ de 1 isina. A conversão alimentar só melhorou com adição de $1,5 \%$ de farinha de pe $\underline{i}$ xe ou uma mistura desta com $0,5 \%$ de 1 isina.

No mesmo ano trabalhando com suínos em crescimen to e acabamento, NIELSEN et alii. (1963) observaram um efeito benéfico da adição de lisina a rações com níveis de proteína sub-ótimos, tanto para ganho de peso como para conversão alimentar. As rações possuiam como fonte energética o milho ou a cevada e como fonte protéica o farelo de soja. Nas rações com teor normal de proteína a adição não teve o mesmo efeito.Peque nas melhoras, apesar de não significativas estatísticamente pa ra ganho de peso e conversão alimentar, foram observadas quando a fonte energética foi o milho.

SOLDEVILA e MEADE (1964) não encontraram aumento significativo na retenção de nitrogênio, quando lisina e me tionina foram adicionadas a uma ração constituída de cevada mais farelo de soja para suínos em crescimento.

MEADE et alii (1966a) não encontraram, para ganho de peso e conversão alimentar, efeito da adição $0,15^{\circ}$ de lisina a rações com 15 e $12 \%$ de proteína bruta, para suínos em crescimento e acabamento, sendo que idênticos resultados foram obtidos pelos mesmos autores (MEADE et alii, 1966b) em outro ex perimento, quando adicionaram $0 ; 0,14$ e $0,28 \%$ de 1 isina a uma ração possuíndo $12 \%$ de proteína bruta e 0 e $0,14 \%$ de 1 isina a outra ração com $14 \%$ de proteína bruta.

Trabalhando com suínos dos 57 aos $95 \mathrm{~kg}$, JURGENS et alii. (1967) forneceram rações com 12 ou $16^{\circ}$ de proteína bru 
ta com ou sem adição de $0,1 \%$ de lisina. Os autores não observa ram diferenças șignificativas para ganho de peso e conversão alimentar devido a adição do aminoácido.

Em um estudo do farelo de algodão como fonte pro téica para suínos em crescimento e acabamento, HINTZ e HEITMAN (1967) adicionaram $0,2 \%$ de lisina e obtiveram os seguintes resultados para ganho diắrio de peso e conversão alimentar: 0,710 $\mathrm{kg}$ e 3,$66 ; 0,780 \mathrm{~kg}$ e 3,35 respectivamente para a ração sem 1 isina e a ração com $0,2 \%$ de adição de lisina. As diferenças foram estatísticamente significativas $(P<0,01)$, tanto para ganho diārio de peso como para conversão alimentar.

LARSEN e BELL (1967) observaram um efeito positivo sobre o ganho de peso e conversão alimentar, devido a adi ção de 0,$05 ; 0,1$ e $0,2 \%$ de lisina a uma ração baseada em fare10 de algodão e milho, somente na fase de crescimento.

NOLAND (1968) conseguiu, com a adição de $0,4 \%$ e $0,8 \%$ de lisina ao farelo de algodão, resultados para ganho de peso e conversão alimentar semelhantes aos obtidos quando foi utilizado o farelo de soja, como fonte protéica em rações para leitões com 3 semanas de idade, alimentados durante 4 semanas. Quando o farelo de algodão constituiu fonte exclusiva de proteína, o resultado para ganho de peso foi estatísticamente inferior $(P<0,05)$ aos dos tratamentos tendo o farelo de algodão mais 0,4 ou $0,8 \%$ de lisina.

BLAIR et alii (1969) submeteram 512 animais dos 22,7 até $90,7 \mathrm{~kg}$ a 64 tratamentos, em um experimento com um delineamento fatorial com quatro níveis de lisina $(0,59,0,70$, $0,74$ e $1,04 \%), 4$ níveis de proteína bruta $(12,14,16$ e $18 \%)$ e 4 diferentes níveis de ingestão. Os diferentes níveis de 1isina não tiveram efeito sobre o ganho de peso, mas para conversão alimentar houve melhora significativa $(\mathrm{P}<0,001)$ no nível de $18 \%$ de proteína bruta, durante o período dos 22,7 até $54,3 \mathrm{~kg}$. MONCADA e MANER (1970) adicionaram 0,1\% de 1 is $\underline{i}$ na a rações com diferentes níveis de farelo de algodão, fornecidos a suínos em crescimento e acabamento, e observaram que 
houve um aumento no ganho de peso, devido a adição de lisina às rações com 11,$4 ; 15,0$ e $20 \%$ de farelo de algodão respectivamente $(0,794 \times 0,805 \mathrm{~kg}, 0,757 \times 0,814 \mathrm{~kg}$ e $0,642 \times 0,776 \mathrm{~kg})$. Entretanto esta melhora no ganho de peso observada pelos autores não foi encontrada por STOCKLAND et alii (1971), quando adicionaram $0,2 \%$ de lisina a uma ração basal de $16 \%$ de proteína bruta, cons tituida de milho mais farinha de carne e ossos, fornecida para suínos em crescimento.

WAHLSTROM et alii (1971) realizaram 3 ensaios es tudando adição de lisina na ração e fornecida na água de beber. No ensaio 1 , os autores forneceram rações de 16 ou $12 \%$ de proteína bruta sem ou com adição de $1.057 \mathrm{mg}$ de lisina por litro de água de beber, apresentando os seguintes resultados para ganho diário de peso, consumo e conversão alimentar: $0,85 \mathrm{~kg}, 2,70 \mathrm{~kg}$ e 3,$17 ; 0,83 \mathrm{~kg}, 2,62 \mathrm{~kg}$ e 3,$17 ; 0,72 \mathrm{~kg}, 2,49 \mathrm{~kg}$ e 3,$44 ; 0,77 \mathrm{~kg}, 2,41 \mathrm{~kg}$ e 3,12 respectivamente para o tratamento com $16 \%$ de proteína bru ta sem e com adição de lisina e o de $12 \%$ sem e com adição de $1 \underline{i}$ sina. Dos resultados apresentados, somente a conversão alimentar no tratamento de $12 \%$ de proteína com adição de lisina, foi supe rior aos demais significativamente $(P<0,05)$. O ensaio 2 comparou 5 tratamentos: ração controle, ração controle mais adição de 0,1 ou $0,3 \%$ de lisina e ração controle mais 0,1 ou $0,3 \%$ de 1 is $\underline{i}$ na fornecida na água de beber. Os resultados obtidos após 99 dias de ensaio com os animais com $7,3 \mathrm{~kg}$ de peso inicial não mostraram diferenças significativas. No $3{ }^{\circ}$ ensaio a adição de $0,3 \%$ de lisina na ração ou na água de beber teve um efeito positivo sig nificativo $(\mathrm{P}<0,05)$ sobre o ganho de peso e conversão alimentar. WAHLSTROM e LIBAL (1974) conseguiram com a adição de $0,1 \%$ de lisina a uma ração com $14 \%$ de proteína bruta para o período de crescimento e $11 \%$ no período de acabamento, resultados semelhantes aos obtidos em rações com 17 e $14 \%$ de proteína bruta sem adição de lisina, respectivamente para o perío do de crescimento e acabamento, sendo todas rações constituídas de milho e farelo de soja.

Recentemente, KNABE et alii (1975) trabalhando 
com suínos durante a fase de crescimento submeteram os animais a três tratamentos, representados por rações com níveis de 0,60; 0,70 e $0,80 \%$ de lisina. Obtiveram resposta quadrática para con sumo $(P<0,10)$ e ganho de peso $(P<0,05)$. Os resultados para ganho diário de peso, consumo diário de ração e conversão alinen tar foram: $0,740 \mathrm{~kg}, 2,18 \mathrm{~kg}$ e 2,$94 ; 0,831 \mathrm{~kg}, 2,35 \mathrm{~kg}$ e 2,$35 ; 0,831 \mathrm{~kg}$, $2,29 \mathrm{~kg}$ e 2,77 ; respectivamente, para os três níveis de lisina na ração.

DAVEY e FROBISH (1975) conseguiran melhorar o ganho de peso e conversão alimentar, quando adicionaram lisina a uma ração para suínos em crescimento e acabamento baseada em milho, farelo de soja e feno de alfafa, contendo $12 \%$ de proteí na bruta.

Trabalhando com 126 suínos durante a fasede cres cimento, FETUGA et alii (1975) conduziram um ensaio com suínos dos 8 aos $50 \mathrm{~kg}$ de peso vivo, sendo utilizado um delinemento fa torial com quatro níveis de lisina: $0 ; 0,05 ; 0,10$ e $0,15 \%$ e quatro níveis protéicos: $16,18,20$ e $22 \%$. A adição de $0,15 \%$ de lisina as rações com 16,18 e $20 \%$ de proteína bruta para os ani mais entre 8 e $34 \mathrm{~kg}$ de peso vivo, aumentou significativamente $(\mathrm{P}<0,05)$ os ganhos de peso, quando comparado com as rações cor respondentes sem adição de lisina, sendo o melhor resultado ob tido com o nível de $20 \%$ de proteína bruta. Entre 8 e $50 \mathrm{~kg}$, o melhor resultado para o ganho de peso foi o nível de $20 \%$ de pro teína bruta com $0,15 \%$ de lisina e para conversão alimentar o melhor resultado foi obtido com ração contendo $20 \%$ de proteína bruta e $0,1 \%$ de lisina.

IVAN e FARRELL (1975) estudaram o efeito da suplementação da lisina a uma ração composta por trigo, comparada com duas outras rações, sendo a primeira constituída de trigo suplementado por farinha de carne e farinha de peixe e a outra uma ração comercial. A ração de trigo com suplementação de 1isina mostrou para ganho de peso e conversão alimentar resultados semelhantes ao da ração comercial, mas inferiores à ração de trigo suplementada com farelo de carne e farelo de peixe. 
Mais recentemente, SHARDA et alii (1976) conduziram ensaios com suínos em crescimento e acabamento com a fi-. nalidade de avaliar a adição de vârios aminoácidos, entre eles lisina, a uma dieta constituída de milho e farelo de soja. Durante a fase de crescimento, 2 ensaios foram conduzidos havendo em ambos, uma dieta controle positiva com $16 \%$ de proteína bruta, uma dieta controle negativa no 1 : ensaio com $14 \%$ de pro teina bruta e no $2 \%$ ensaio com $12 \%$, todas com $0,78 \%$ de 1 isina. No $1 \%$ ensaio a dieta de $14 \%$ de proteína resultou ganho de peso, consumo e conversão alimentar similares ao da dieta com $16 \%$ de proteína, o que não ocorreu no $2^{\circ}$ ensaio, tendo o ganho de peso piorado quando os animais receberam a ração de $12 \%$ de proteína. No período de acabamento uma ração com $10 \%$ de proteína com $0,60 \%$ de lisina apresentou resultados para o ganho de peso, consumo e conversão alimentar inferiores $(P<0,05)$ a testemunha com $13 \%$ de proteína e $0,57 \%$ de 1 isina, sendo que em um $2{ }^{\circ}$ ensaio não houve diferença entre os resultados obtidos entreidên ticas rações.

\subsection{Efeito da adição de lisina na qualidade das carcaças}

As variações das características das carcaças, são reflexos do manejo, da nutrição e das raças dos aninais uti lizados.

Segundo HAYS (1968) a qualidade da carcaça depen de $5 \%$ da genética, $10 \%$ da nutrição e $85 \%$ do manejo do sistema. No tocante a nutrição WALLACE (1968) menciona que um balancea mento incorreto em aminoácidos pode piorar as características da carcaça.

SEWELL e PRICE (1962) não observaram diferenças significativas, estatisticamente, para qualquer uma das seguintes características da carcaça: espessura do toicinho, peso do lombo, comprimento da carcaça, ārea do olho de lombo e percentagem dos cortes cárneos, devidas a adição de lisina. Resultados 
semelhantes foram obtidos por NIELSEN (1963), com a adição de lisina a rações com teor de proteína bruta dentro da exigência normal não obteve efeito positivo, mas quando o teor de proteí na bruta foi sub-ótimo, a adição de lisina teve um efeito bené fico na qualidade de carcaça.

REIMER et alii, (1964) não encontraram efeito po sitivo da adição de lisina e metionina, a rações de crescimento e acabamento com cevada como fonte energética, sobre a espessura do toicinho, área do olho de lombo, percentagem de per nil e lombo. Igualmente MEADE et alii (1966a) não encontraram nenhum efeito da suplementação de $0,15^{\circ}$ de lisina à ração mi1ho-farelo de soja, sobre o rendimento da carcaça, espessura do toicinho, área do olho de lombo, percentagem dos cortes magros, percentagem de pernil e lombo.

Os mesmos autores MEADE et alii (1966b) em outro experimento, determinaram a espessura do toicinho, a área do olho de lombo e a percentagem do pernil em carcaças provenientes de animais alimentados com uma ração baseada em milho e farelo de soja, com 3 níveis de suplementação com lisina,não encontrando diferenças significativas entre os tratamentos. Do mesmo modo HINTZ e HEITMAN (1967), constataram que a adição de lisina não afetou a espessura do toicinho e a percentagem dos cortes cârneos.

No mesmo ano JURGENS et alii (1967), trabalhando com 120 animais adicionaram $0,1 \%$ de 1 isina a duas rações baseadas em grãos de sorgo e farelo de soja, com níveis de 16 e $12 \%$ de proteína bruta. Os resultados mostraram que a adição de lis na diminuiu o rendimento de carcaça $(68,4 \times 69,4 \%)$ significativamente $(\mathrm{P}<0,05)$, sendo este resultado a média dos tratamentos com 16 e $12 \%$ de proteína bruta com e sem adição de lisina. As percentagens de lombo e pernil foram significativamente aumenta das $(\mathrm{P}<0,05)$ pela adição de lisina na dieta. A área de olho de lombo na ração com $12 \%$ de proteína bruta com adição de lisina, foi maior que no tratamento sem lisina, embora não significativamente. 
BELL e VOLDENG (1968) forneceram rações em três níveis de lisina $\left(0,58 ; 0,68\right.$ e $\left.0,78_{0}^{\circ}\right)$ para suínos em crescimen to e acabamento, e não encontraram diferenças significativas en tre as características de carcaça estudadas.

Resultados semelhantes foram obtidos por BLAIR et alii (1969), os quais também constataram que não houve efeito da adição de lisina no aumento dos percentuais dos cortes cárneos de suínos abatidos com diferentes pesos, ou seja, com 45,68 e $91 \mathrm{~kg}$ de peso vivo.

RODRIGUES et alii (1969) trabalhando com adição de lisina concluíram que houve melhora da qualidade de carcaça, representada principalmente pela área do olho de lombo que de $22,35 \mathrm{~cm}^{2}$, na ração testemunha, passou para $26,50 \mathrm{~cm}^{2}$ na ração com adição de lisina.

BROWN et alii. (1973) conduziram um ensaio com 6 tratamentos que se diferenciam pelo nível de lisina da ração ou seja: 0,$35 ; 0,45 ; \cdots 0,55 ; 0,65 ; 0,75$ e $0,85 \%$, sendo a ração basal constituída de milho de farelo de gergelim. Obtiveram, respectivamente, os seguintes resultados: 1) percentual de cortes cárneos ná carcaça fria - 52,8;54,4;55,5;55,7;55,6 e 55,3\%; 2) área do olho de 1ombo - 24,30;25,90;28,30;29,00;28,30 e $26,40 \mathrm{~cm}^{2}$; 3) espessura do toicinho - 3,41; 3,42;3,34; 3,35; 3,37 e $3,20 \mathrm{~cm}$; 4) comprimento da carcaça-78,4;78,5;78,8;78,2;78, e 78,6 $\mathrm{cm}$. 5) rendimento de carcaça: 72,$9 ; 73,8 ; 73,5 ; 73,8 ; 73,6$ e $71,7 \%$. Náo hou ve diferença estatisticamente significativa para nenmum dos parâmet ros. Adicionando $0,1 \%$ de lisina a uma ração basal ou a ảgua de beber, fornecida a suínos de crescimento e acabamento, SEERLEY et alii (1973) observaram que a lisina adicionada, tanto na ração como na água, teve um efeito positivo mas não significativo para área do olho de 1 ombo, aumentando de $26,70 \mathrm{~cm}^{2}$ no tratamento testemunha para $29,40 \mathrm{~cm}^{2}$ no tratamento com 1 isina na ração e $29,10 \mathrm{~cm}^{2}$ no tratamento 1 isina na água de beber.o comprimento da carcaça, percentagem do pernil e percentagem do lombo não foram afetados pela adição de lisina em nenhuma das duas formas. 
WAHLSTRON e LIBAL (1974) adicionaram 0,1 e $0,2 \%$ de lisina a uma ração baseada em milho e farelo de soja fornecida a suínos em crescimento e acabamento, e não encontraram diferenças significativas para comprimento de carcaça, espessu ra do toicinho e área do olho de lombo.

Recentemente CRESWELL et alii (1975) trabalharam com 84 animais dos 25 aos $95 \mathrm{~kg}$, aos quais forneceram rações com alto $17^{\circ}$ na fase de crescimento e $15 \%$ na fase de acabamento) e baixo teor de proteína (13\% na fase de crescimento e $11 \%$ na fase de acabamento). Os animais que receberam rações com baixo teor de proteína bruta, sofreram um efeito negativo na qualidade da carcaça, efeito este que foi evitado com a adição de $0,15 \%$ de 1 isina àquelas rações. 
4. MATERIAL E MÉTODOS

4.1. Ensaio I

4.1.1. Loca1, material experimental e duração do ensaio

0 presente trabalho foi realizado em instalações. do Instituto de Zootecnia em Nova Odessa. 0 local está situado a $550 \mathrm{mts}$. de altitude a $\mathrm{S}-22^{\circ} 42^{\prime}$ de latitude e $47^{\circ} 18^{\prime}$ - W. Gr. de 1ongitude. A temperatura média anual é de $22,3^{\circ} \mathrm{C}$ e a precipi tação anual de $1.300 \mathrm{~mm}$. Na TABELA $\mathrm{A}_{1}$ podemos observar os dados das condições climáticas durante o transcorrer do presente ensaio.

Foram utilizados 30 animais machos castrados pro venientes de cruzamento triplo entre as raças Landrace, Wessex e Duroc, com a idade aproximada de 75 dias no início do período experimental. A média de peso vivo dos animais no inx́cio do ensaio foi de $23,57 \mathrm{~kg}$, e no final de $91,14 \mathrm{~kg}$. Antes do início do ensaio os animais foram submetidos a um período pré-experimental de 10 dias, durante o qual os mesmos receberam vacina contra pes te suína, e uma dose de vermífugo injetável.

$$
\text { Após o término do período pré-experimental os }
$$

animais foram pesados e tatuados na orelha, e após formados os blocos, foram distribuídos em baias individuais. A seguir foram 
sorteados os tratamentos dentro de cada bloco.

0 período experimental foi de 91 dias, sendo que a pesagem inicial foi no dia 16 de setembro de 1975 e a pesagem final a 16 de dezembro do mesmo ano. Os animais destinados a anạ lise da carcaça foram abatidos no dia seguinte ao final do ensaio, após jejum de 48 horas de ração e 12 horas de água.

4.1.2. Manejo da alimentação, pesagens e amostragens

Os animais receberam ração à vontade, a qual era fornecida 3 vezes ao dia em comedouros simples nos quais sempre existia alguma quantidade de ração. Foram tomados todos os cuidados possíveis para evitar perda de alimento dos comedouros. A água foi fornecida à vontade.

As pesagens foram efetuadas a cada 14 dias, sen do que o último período experimental foi de 7 dias, devido a média de peso vivo dos animais em um dos tratamentos ter atingido o peso pré-determinado de encerramento do período experimental, ou seja de 90 a $95 \mathrm{~kg}$. A troca das rações de $16 \%$ de pró teína para 13\% foi realizada quando os animais de um dos trata mentos atingiram $55-60 \mathrm{~kg}$.

Foram realizadas amostragens dos ingredientes de rações como milho, farelo de soja, farelo de algodão, sendo após enviados para o laboratório e feita as seguintes determinações: proteína bruta, fibra bruta, extrato etéreo e matéria mineral. Foram retiradas várias amostras do farelo de algodão a após ser feita uma amostra composta da mesma, foi analisada para gossipol livre, segundo método de AOCS (1974).

Os resultados das análises dos ingredientes, po dem ser vistos na TABELA 1.

\subsubsection{Rações experimentais}

0 presente trabalho teve 5 rações para o perío- 
TABELA 1 - Anālise Bromatológica e Energia Metabolizāvel dos Ingredientes - Ensaio I

\begin{tabular}{|c|c|c|c|c|}
\hline & \multicolumn{3}{|c|}{ Tratamentos } & \multirow[b]{2}{*}{$\begin{array}{l}\text { Fosfato } \\
\text { Bicālcico* }\end{array}$} \\
\hline & Milho* & F. Soja* & F. Algodão* & \\
\hline Proteína Bruta : & 8,82 & 45,10 & 40,94 & - \\
\hline Fibra Bruta $\%$ & 2,82 & 5,87 & 13,83 & - \\
\hline Extrato Etéreo : & 5,30 & 2,12 & 1,59 & - \\
\hline Matēria Mineral : & 1,63 & 7,03 & 7,83 & - \\
\hline Cálcio \% * * & 0,02 & 0,32 & 0,16 & 22,20 \\
\hline Fósforo Disponível $\%$ * * & 0,10 & 0,22 & 1,20 & 17,90 \\
\hline \multicolumn{5}{|l|}{ EN. Metabolizável** } \\
\hline$(\mathrm{kcal} / \mathrm{kg})$ & 3.394 & 2.851 & 2.692 & - \\
\hline Gossipol Livre*** & - & - & 0,07 & - \\
\hline
\end{tabular}

* Anālise realizada pelo Laboratório de Bromatologia do Instituto de Zootecnia.

** NRC (1973).

*** Análise realizada pelo ITAL. 
TABELA 2 - Composição das Rações Experimentais - Período de Crescimento Ensaio I

1

\begin{tabular}{lccrrr}
\hline & \multicolumn{5}{c}{ Tratamentos } \\
\cline { 2 - 6 } Ingredientes : & 1 & 2 & 3 & 4 & 5 \\
\hline Milho* & 76,7 & 76,1 & 75,5 & 74,8 & 74,1 \\
Farelo de Soja* & 20,6 & 15,9 & 10,9 & 5,6 & - \\
Farelo de Algodão* & - & 5,3 & 10,9 & 16,9 & 23,2 \\
Fosfato Bicálcico & 2,0 & 2,0 & 2,0 & 2,0 & 2,0 \\
Sal Iodatado & 0,5 & 0,5 & 0,5 & 0,5 & 0,5 \\
Premix** & 0,2 & 0,2 & 0,2 & 0,2 & 0,2 \\
\hline TƠTAL & 100,00 & 100,00 & 100,00 & 100,00 & 100,00 \\
\hline
\end{tabular}

VALORES CALCULADOS

Tratamentos

\begin{tabular}{lccccc}
\cline { 2 - 6 } & 1 & 2 & 3 & 4 & 5 \\
\hline Proteína Bruta : & 16,04 & 16,03 & 16,01 & 16,04 & 16,01 \\
Fibra Bruta : & 3,4 & 3,8 & 4,3 & 4,8 & 5,3 \\
En.Metab.Kcal/kg & 3.190 & 3.160 & 3.128 & 3.098 & 3.058 \\
Lisina : & 0,735 & 0,688 & 0,637 & 0,584 & 0,528 \\
Metionina : & 0,193 & 0,198 & 0,204 & 0,211 & 0,217 \\
Cistina : & 0,207 & 0,220 & 0,234 & 0,248 & 0,263 \\
Triptofano: & 0,193 & 0,198 & 0,204 & 0,211 & 0,217 \\
Cálcio : & 0,525 & 0,518 & 0,511 & 0,504 & 0,496 \\
Fósforo Disp. : & 0,480 & 0,490 & 0,501 & 0,513 & 0,525 \\
\hline
\end{tabular}

* Ver a composição na TABELA 1

** Ver a composição na TABELA 5 
do de crescimento e 5 rações para o acabamento, constituíndo os seguintes tratamentos, de acordo com a fonte de proteína: $\mathrm{T}_{1}$ $100 \%$ de farelo de soja; $\mathrm{T}_{2}$ - $75 \%$ de farelo de soja e $25 \%$ de farelo de algodão; $\mathrm{T}_{3}$ - $50 \%$ de farelo de soja e $50 \%$ de farelo de algodão; $\mathrm{T}_{4}-25 \%$ de farelo de soja e $75 \%$ de farelo de algodão; $\mathrm{T}_{5}-100 \%$ de farelo de algodão.

Os animais receberam rações que possuíam $16 \%$ de proteína bruta na fase de crescimento do peso inicial até $55-60 \mathrm{~kg}$ de peso vivo e 13\% de proteína bruta na fase de acabamento dos $55-60 \mathrm{~kg}$ até o peso vivo de abate. As composições das rações são apresentadas nas TABELAS 2 e 3 para os períodos de crescimento e acabamento respectivamente.

0 sulfato de ferro $\left(\mathrm{FeSO}_{4} 7 \mathrm{H}_{2} \mathrm{O}\right)$, foi adicionado na base de 1 ppm de ferro para cada ppm de gossipol livre como mostra a TABELA $A_{3}$. A composição do premix mineral vitamínico utilizado pode ser visto na TABELA 5. Na TABELA 4 é observada a composição em aminoācidos do farelo de algodão, farelo de soja e milho grão.

\subsubsection{Delineamento experimental}

Delineamento experimental foi em blocos ao acaso, com 5 tratamentos e seis repetições ( 6 blocos). A análise estatística foi auxiliada pelo uso de sistema de regressões polinomiais segundo PIMENTEL (1970). O critério para formação dos blocos foi o peso inicial dos leitões. As diferenças entre médias dos tratamentos foram submetidos ao teste de DUNCAN segundo PIMENTEL (1970).

\subsubsection{Instalações}

Os animais foram colocados em baias individuais medindo $2,58 \mathrm{~m} \times 1,50 \mathrm{~m}$ com piso de concreto, possuíndo o comedouro $1,40 \mathrm{~m}$ de comprimento, $0,2 \mathrm{~m}$ de altura e $0,3 \mathrm{~m}$ de largura. 
TABELA 3 - Composição das Rações Experimentais - Período de Acabamento Ensaio I

\begin{tabular}{lccccc}
\hline INGREDIENTES : & \multicolumn{5}{c}{ Tratamentos } \\
\cline { 2 - 6 } & 1 & 2 & 3 & 4 & 5 \\
\hline Milho * & 85,1 & 84,7 & 84,15 & 83,75 & 83,45 \\
Farelo de Soja* & 12,25 & 9,49 & 6,5 & 3,37 & - \\
Farelo de Algodão* & - & 3,16 & 6,5 & 10,13 & 13,9 \\
Fósfato Bicálcico & 2,0 & 2,0 & 2,0 & 2,0 & 2,0 \\
Sal & 0,5 & 0,5 & 0,5 & 0,5 & 0,5 \\
Premix ** & 0,15 & 0,15 & 0,15 & 0,15 & 0,15 \\
\hline TOTAL & 100,00 & 100,00 & 100,00 & 100,00 & 100,00 \\
\hline
\end{tabular}

VALORES CALCULADOS

Tratamentos

\begin{tabular}{lccccc}
\cline { 2 - 6 } & 1 & 2 & 3 & 4 & 5 \\
\hline Proteína Bruta : & 13,01 & 13,02 & 13,00 & 13,03 & 13,03 \\
Fibra Bruta $:$ & 3,11 & 3,37 & 3,64 & 3,94 & 4,25 \\
En.Metab.Kcal/Kg & 3.238 & 3.230 & 3.216 & 3.211 & 3.206 \\
Lisina $:$ & 0,508 & 0,481 & 0,450 & 0,421 & 0,387 \\
Metionina $:$ & 0,150 & 0,154 & 0,157 & 0,161 & 0,165 \\
Cistina $:$ & 0,159 & 0,167 & 0,174 & 0,184 & 0,190 \\
Triptofano $:$ & 0,150 & 0,154 & 0,157 & 0,161 & 0,165 \\
Cálcio : & 0,500 & 0,496 & 0,492 & 0,488 & 0,483 \\
Fósforo Disp. : & 0,470 & 0,476 & 0,482 & 0,488 & 0,497 \\
\hline
\end{tabular}

* Ver a composição na TABELA 1

** Ver a composição na TABELA 5 
TABELA 4 - Composição em Aminoácidos do Farelo de Algodão, Farelo de Soja e Milho grão

\begin{tabular}{lcccccccc} 
AMINOACIDO : & $\mathrm{FA}^{*}$ & $\mathrm{FS}^{*}$ & $\mathrm{M}^{*}$ & $\mathrm{FA}^{* *}$ & $\mathrm{FS}^{* *}$ & $\mathrm{M}^{* *}$ & $\mathrm{FA}^{* * *}$ & $\mathrm{FS}^{* * *}$ \\
\hline Arginina & 3,11 & 2,61 & 0,36 & 4,25 & 3,20 & 0,45 & 4,20 & 3,10 \\
Histidina & 1,09 & 1,03 & 0,22 & 1,10 & 1,10 & 0,18 & 1,09 & 1,00 \\
Lisina & 1,13 & 2,43 & 0,23 & 1,70 & 2,90 & 0,18 & 1,45 & 2,65 \\
Tirosina & 1,43 & 1,85 & 0,55 & 0,70 & 1,40 & - & 0,77 & 1,28 \\
Triptofano & 0,55 & 0,63 & 0,05 & 0,65 & 0,60 & 0,09 & 0,48 & 0,60 \\
Fenilalanina & 2,77 & 1,85 & 0,41 & 2,35 & 2,20 & 0,45 & 1,92 & 2,15 \\
Cistina & 0,84 & 0,59 & 0,10 & 0,85 & 0,67 & 0,09 & 0,66 & 0,72 \\
Metionina & 0,67 & 0,81 & - & 0,65 & 0,60 & 0,09 & 0,52 & 0,60 \\
Treonina & 1,26 & 1,80 & 0,32 & 1,45 & 1,70 & 0,36 & 1,19 & 1,67 \\
Leucina & 5,88 & 3,60 & 1,94 & 2,50 & 3,40 & 0,99 & 2,25 & 3,45 \\
Isoleucina & 1,47 & 1,80 & 0,32 & 1,60 & 2,50 & 0,45 & 1,24 & 2,00 \\
Valina & 2,94 & 1,58 & 0,41 & 2,05 & 2,40 & 0,36 & - & - \\
Glicina & 2,22 & 0,45 & - & - & - & 0,36 & 1,62 & 1,91 \\
\hline
\end{tabular}

$$
\begin{aligned}
\mathrm{FA} & =\text { Farelo de Algodão } \\
\mathrm{FS} & =\text { Farelo de Soja } \\
\mathrm{M} & =\text { Milho Grão } \\
* & =\text { CRAMPTON \& HARRIS (1969) } \\
* * & =\text { NRC }-1973 \\
* * * & =\text { Rações Anhanguera }
\end{aligned}
$$




\subsubsection{Classificação das carcaças}

A classificação das carcaças foi feita segundo as normas da ABCS (1973).

As mensurações na carcaça foram efetuadas no dia seguinte ao abate, após as mesmas permanecerầm 24 horas na câma ra fria. o comprimento da carcaça foi tomado do bordo cranial da sinfise pubiana ao bordo crânio-ventral do atlas. A medida da espessura do toicinho foi a média aritmética da medida en três locais: 1)Espessura do toicinho na 1 a costela; 2) Espessura do toicinho na última costela; 3) Espessura do toicinho entre a pe núltima e ūltima vértebra lombar.

A medida da área do olho de lombo foi feita na secção corte efetuada na altura da medida da espessura do toic nho na última costela.

Para separação do pernil efetuou-se um corte per pendicular à linha dorsal na altura da articulação entre a últi ma e a penúltima vértebras lombares. Após o pernil foi pesado completo, com cauda, pés sem unhas e sem nenhum retoque na carne ou na gordura. 0 peso do pernil para análise foi representado em porcentagem do peso da carcaça fria.

\subsection{Ensaio II}

4.2.1. Local, material experimental e duração do ensaio

O Ensaio II foi realizado no mesmo local do Ensaio I. A TABELA $A_{2}$ apresenta os dados climáticos coletados durante o transcorrer do ensaio.

Foram utilizados 28 animais machos castrados provenientes de cruzamento triplo entre as raças Landrace, Wessex e Duroc, com a idade aproximadamente de 55 dias no início do pe ríodo experimental, sendo o peso médio inicial dos animais de 
TABELA 5 - Composição do Premix - Ensaio I e II

A

$\mathrm{D}_{2}$

$\mathrm{B}_{2}$

$\mathrm{B}_{12}$

Ácido Pantotenico

Niacina

Zinco

Manganês

Ferro

Iodo

Cobre
$4.000 .000 \mathrm{U} . \mathrm{I}$.

200.000 U.I.

$2.000 \mathrm{mg}$

$15,0 \mathrm{mg}$

$10,0 \mathrm{~g}$

$10,0 \mathrm{~g}$

$21,3 \mathrm{~g}$

$12,0 \mathrm{~g}$

$29,7 \mathrm{~g}$

$2,9 \mathrm{~g}$

$10,0 \mathrm{~g}$ 
$18,75 \mathrm{~kg}$ e o peso médio final de $87,16 \mathrm{~kg}$. O manejo dos animais foi semelhante ao do Ensaio I. A duração do ensaio foi de 91 dias, abrangendo o período de 27 de janeiro a 28 deabril de 1977.

\subsubsection{Manejo da alimentação, pesagens e amostragens}

Tanto o arraçoamento, como as pesagens, foram rea lizadas de maneira idêntica ao Ensaio I. Na TABELA 6 são mostra dos os resultados das análises dos ingredientes das rações expe rimentais.

O período experimental para medida de desempenho, terminou quando os animais em um dos tratamentos atingiram média de $95 \mathrm{~kg}$ de peso vivo. Para estudo da qualidade de carcaça, conforme a média de peso dos animais em cada um dos tratamentos atingisse $95 \mathrm{~kg}$ de peso vivo, os mesmos foram levados ao abate e a avaliação da carcaça foi feita de acordo com as normas da ABCS (1973).

\subsubsection{Rações experimentais}

0 presente ensaio estudou 7 tratamentos, nos quais a fonte protéica variou da seguinte forma: $\mathrm{T}_{1}$ - Farelo de soja $(100 \%), \mathrm{T}_{2}$ - Farelo de algodão $(100 \%), \mathrm{T}_{3}$ - Farelo de algodão $(100 \%)+0,2 \%$ de 1 isina, $\mathrm{T}_{4}-$ Farelo de algodão $(100 \%)+0,4 \%$ de lisina, $\mathrm{T}_{5}$ - Farelo de soja $(25 \%)+$ Farelo de algodão $(75 \%)$, $\mathrm{T}_{6}-$ Farelo de soja $(25 \%)+$ Farelo de algodão $(75 \%)+0,2 \%$ de lisina, $\mathrm{T}_{7}-$ Farelo de $\operatorname{soja}(25 \%)+$ Farelo de algodão $(75 \%)+$ $0,4 \%$ de lisina.

A composição das rações pode ser vista na TABELA 7 e 8 para os períodos de crescimento e acabamento respectivamente.

As rações possuiam $16 \%$ de proteína bruta na fase de crescimento do peso inicial até $55-60 \mathrm{~kg}$ de peso vivo, e 13\% 
TABELA 6 - Análise Bromatológica e Energia Metabolizáve1 dos Ingredientes Ensaio II

\begin{tabular}{lcccc}
\hline & \multicolumn{3}{c}{ INGREDIENTES } \\
\cline { 2 - 5 } & Milho & F. Soja & F. Algodão & F. Bicálcico \\
\hline Proteína Bruta $\% *$ & 8,75 & 46,37 & 41,31 & - \\
Fibra Bruta $\%$ & 2,03 & 5,33 & 13,96 & - \\
Extrato Etéreo $\% *$ & 3,57 & 1,93 & 1,57 & - \\
Matéria Mineral $\% *$ & 1,34 & 6,73 & 7,04 & - \\
Cá1cio $\% * *$ & 0,02 & 0,32 & 0,16 & 22,20 \\
Fósforo Disponível $\% * *$ & 0,10 & 0,22 & 1,20 & 17,90 \\
En.Metab. (Kac1/Kg)** & 3.394 & 2.851 & 2.692 & - \\
Gossipol Livre $\% * * *$ & - & - & 0,07 & - \\
\hline
\end{tabular}

* Análise realizada pelo Laboratório de Bromatologia do Instituto de Zootecnia.

** NRC (1973)

*** Análise realizada pelo ITAL 
35.

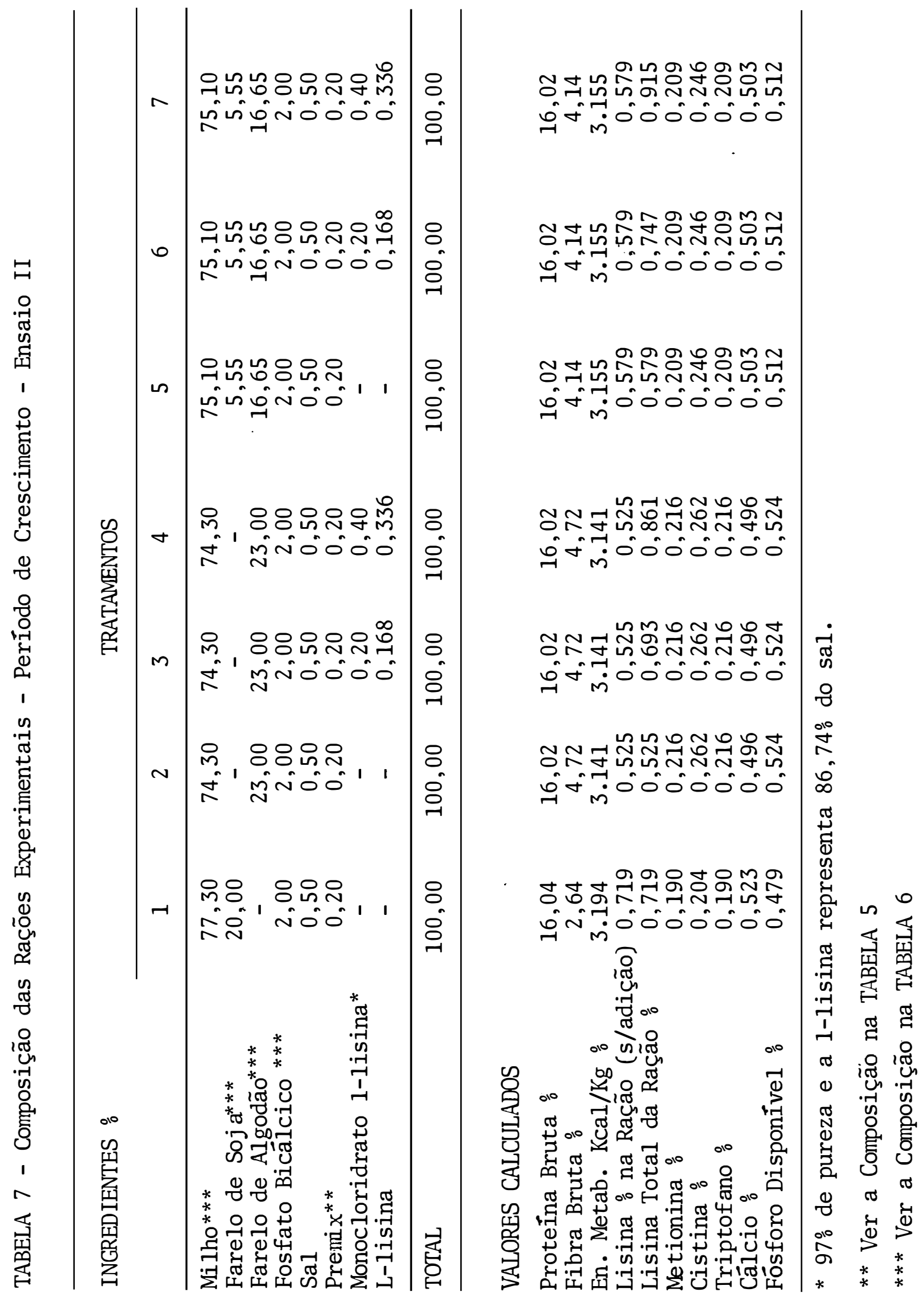


36.

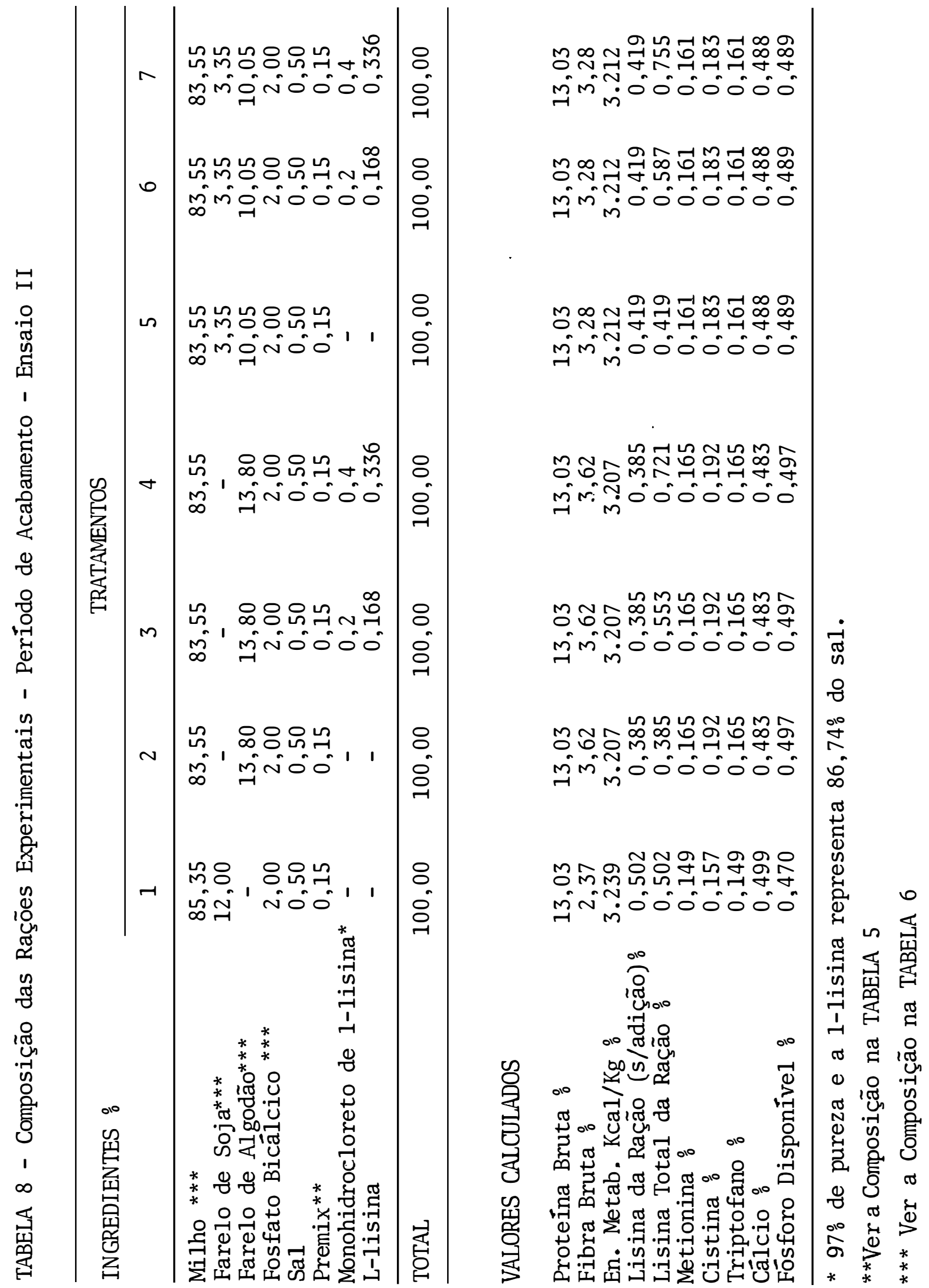


de proteína bruta na fase de acabamento dos 55-60kg até o peso de abate, sendo a troca de ração efetuada quando os animais de um dos tratamentos atingiram $55-60 \mathrm{~kg}$ de peso. Foi adicionado sulfato de ferro de maneira semelhante ao Ensaio I ou seja $1 \mathrm{ppm}$ de ferro para cada ppm de gossipol livre, como pode ser observado na TABELA $\mathrm{A}_{4}$.

A lisina foi adicionada na forma de monoclorohidrato de L-1isina com $97 \%$ de pureza contendo $86,74 \%$ de L-1isina. A composição do premix mineral vitamínico utilizado pode ser visto na TABELA 5 .

\subsubsection{Delineamento experimental}

0 delineamento experimental foi em blocos ao aca so com 7 tratamentos e 4 repetições (blocos), desdobrando-se a soma dos quadrados dos tratamentos segundo o seguinte esquema:

CAUSA DE VARIAÇÃO

GL

$\mathrm{T}-1 \times(\mathrm{T}-2, \mathrm{~T}-3, \mathrm{~T}-4, \mathrm{~T}-5, \mathrm{~T}-6, \mathrm{~T}-7)$

$(\mathrm{T}-2, \mathrm{~T}-3$ e $\mathrm{T}-4) \times(\mathrm{T}-5, \mathrm{~T}-6$ e $\mathrm{T}-7)$

(T-2, T-3 e T-4) - Regressão linear

(T-2, T-3 e T-4) - Regressão quadrática

(T-5, T-6 e T-7) - Regressão linear

(T-5, T-6 e T-7) - Regressão quadrātica

$\mathrm{T}$ = tratamento. As médias dos 7 tratamentos foram comparadas pe 1o teste de Duncan, segundo PIMENTEL (1970).

4.2.5. Instalações

Foram usadas as mesmas instalações do Ensaio I. 
4.2.6. Classificação das carcaças

Foi feita segundo as normas da ABCS (1973) já mencionadas . 
5.1. Ensaio I.

5.1.1. Ganho de peso

Os resultados para os ganhos de peso dos animais e suas anâlises estatísticas durante o período total, período de crescimento e período de acabamento podem ser vistos nas TA BELAS 9,$10 ; 11,12 ; 13,14$; respectivamente. Os pesos individuais e os ganhos de peso dos animais durante o período experi mental são apresentados nas TABELAS $A_{5}$ e $A_{6}$.

A anâlise de variância comum não mostrou diferenças significativas entre os tratamentos, mas quando foi rea lizada a decomposição das somas de quadrados dos tratamentos nos componentes das regressões foi observado um efeito linear significativo, tanto para o período total $(\mathrm{P}<0,05)$ como para o período de crescimento $(\mathrm{P}<0,01)$, devido ao aumento da percentagem do farelo de algodão na ração.

As FIGURAS 1 e 2 mostram as curvas dos valores observados e calculados e as respectivas equações de regressão que foram: $Y=72,05-0,0893 \mathrm{X}$ e $\mathrm{Y}=34,6-0,066 \mathrm{X}$ para $\circ$ pe ríodo total e o período de crescimento, respectivamente, onde $\mathrm{Y}$ representa $\mathrm{o}$ ganho de peso médio em $\mathrm{kg}$ durante o período e $\mathrm{X}$ 
TABELA 9 - Ganho de Peso (kg) Período Tota1 (91 dias) - Ensaio I

\begin{tabular}{|c|c|c|c|c|c|c|}
\hline \multirow{2}{*}{ BLOCOS } & \multicolumn{5}{|c|}{ TRATAMENTOS } & \multirow{2}{*}{ TOTAL } \\
\hline & 1 & 2 & 3 & 4 & 5 & \\
\hline 1 & 76,5 & 76,0 & 79,0 & 82,0 & 58,5 & 368,0 \\
\hline 2 & 67,5 & 72,0 & 78,0 & 65,0 & 59,5 & 342,0 \\
\hline 3 & 62,0 & 73,5 & 58,5 & 49,5 & 52,0 & 295,5 \\
\hline 4 & 68,5 & 62,0 & 65,5 & 74,0 & 65,0 & 335,0 \\
\hline 5 & 85,5 & 68,5 & 73,0 & 56,0 & 66,0 & 349,0 \\
\hline 6 & 67,5 & 65,5 & 72,5 & 59,0 & 73,5 & 338,0 \\
\hline Total & 427,5 & 413,5 & 426,5 & 385,5 & 374,5 & 2027,5 \\
\hline Média & 71,25 & 68,92 & 71,08 & 64,25 & 62,42 & \\
\hline
\end{tabular}

TABELA 10 - Anälise de Variância - Ganho de Peso - Período Total - Ensaio I

\begin{tabular}{lrrrl}
\hline Causa de Variação & GL & SQ & QM & F \\
\hline Regressão Linear & 1 & 299,667 & 299,667 & $5,05^{*}$ \\
Regressão Quadrätica & 1 & 27,429 & 27,429 & 0,46 \\
Regressão Cübica & 1 & 0,150 & 0,150 & 0,003 \\
Regressão 4 Grau & 1 & 64,821 & 64,821 & 1,09 \\
\hline Tratamentos & 4 & 391,667 & 97,017 & 1,65 \\
Blocos & 5 & 570,442 & 114,088 & 1,92 \\
Resíduos & 20 & 1185,433 & 59,272 & \\
\hline TOTAL & 29 & 2147,542 & & \\
\hline
\end{tabular}

Coeficiente de variação $=11,39^{\circ}$

* $(\mathrm{P}<0,05)$ 
TABELA 11 - Ganho de Peso (kg) Período de Crescimento (42 dias) - Ensaio I

\begin{tabular}{|c|c|c|c|c|c|c|}
\hline \multirow{2}{*}{ BLOCOS } & \multicolumn{5}{|c|}{ TRATAMENTOS } & \multirow{2}{*}{ TOTAL } \\
\hline & 1 & 2 & 3 & 4 & 5 & \\
\hline 1 & 34,0 & 32,0 & 40,0 & 37,0 & 26,5 & 169,5 \\
\hline 2 & 32,0 & 34,5 & 35,0 & 28,0 & 22,0 & 151,5 \\
\hline 3 & 32,5 & 33,5 & 26,5 & 25,5 & 26,0 & 144,0 \\
\hline 4 & 34,0 & 32,0 & 29,5 & 32,5 & 29,0 & 157,0 \\
\hline 5 & 40,5 & 31,5 & 31,5 & 23,5 & 29,5 & 156,5 \\
\hline 6 & 32,5 & 31,5 & 34,5 & 29,5 & 32,5 & 160,5 \\
\hline Total & 205,5 & 195,0 & 197,0 & 176,0 & 165,5 & 939,0 \\
\hline Media* & $34,2^{\mathrm{a}}$ & $32,5^{a}$ & $32,8^{\mathrm{ab}}$ & $29,3^{b c}$ & $27,6^{\mathrm{C}}$ & \\
\hline
\end{tabular}

* Letras diferentes diferem estatísticamente ao nível de $5 \%$ pelo teste de Duncan.

TABELA 12 - Anālise de Variância - Ganho de Peso - Período de Crescimento Ensaio I

\begin{tabular}{lcrrc}
\hline Causa de Variação & GL & SQ & QM & F \\
\hline Regressão Linear & 1 & 163,35 & 163,35 & $11,65^{* *}$ \\
Regressão Quadrātica & 1 & 6,30 & 6,30 & 0,45 \\
Regressão Cúbica & 1 & 0,06 & 0,06 & 0,004 \\
Regressão 4 Grau & 1 & 11,34 & 11,34 & 0,81 \\
\hline Tratamentos & 4 & 181,05 & 45,26 & $3,23^{*}$ \\
Blocos & 5 & 73,30 & 14,66 & 1,04 \\
Resíduos & 20 & 280,45 & 14,02 & \\
\hline TOTAL & 29 & 534,80 & & \\
\hline
\end{tabular}

Coeficiente de variação - $11,96 \%$

** $(\mathrm{P}<0,01)$

* $(\mathrm{P}<0,05)$ 
TABELA 13 - Ganho de Peso (kg) Período de acabamento(49 dias) - Ensaio I

\begin{tabular}{lrrrrrl}
\hline \multirow{2}{*}{ BLOCOS } & \multicolumn{5}{c}{ TRATAMENTOS } & \multirow{2}{*}{ TOTAL } \\
\cline { 2 - 5 } & \multicolumn{1}{c}{1} & 2 & 3 & 4 & 5 & \\
\hline 1 & 42,5 & 40,0 & 39,0 & 45,0 & 32,0 & 198,5 \\
2 & 35,5 & 37,5 & 43,0 & 37,0 & 37,5 & 190,5 \\
3 & 29,5 & 40,0 & 32,0 & 24,0 & 26,0 & 151,5 \\
4 & 34,5 & 30,0 & 36,0 & 41,5 & 36,0 & 178,0 \\
5 & 45,0 & 37,0 & 41,5 & 32,5 & 36,5 & 192,5 \\
6 & 34,5 & 34,0 & 38,0 & 29,5 & 41,0 & 177,0 \\
\hline Total & 221,5 & 218,5 & 229,5 & 209,5 & 209,0 & 1088,0 \\
Media & 36,9 & 36,4 & 38,2 & 34,9 & 34,8 & \\
\hline
\end{tabular}

TABELA 14 - Análise de Variância - Ganho de Peso - Período de Acabamento Ensaio I

\begin{tabular}{lcrrc}
\hline Causa de Variação & GL & SQ & QM. & F \\
\hline Regressão Linear & 1 & 19,27 & 19,27 & 0,82 \\
Regressão Quadrática & 1 & 8,05 & 8,05 & 0,34 \\
Regressão Cúbica & 1 & 0,50 & 0,50 & 0,02 \\
Regressão 4 Grau & 1 & 21,72 & 21,72 & 0,92 \\
\hline Tratamentos & 4 & 49,54 & 12,38 & 0,52 \\
Blocos & 5 & 284,67 & 56,93 & 2,41 \\
Resíduos & 20 & 471,66 & 23,58 & \\
\hline TOTAL & 29 & 805,87 & & \\
\hline
\end{tabular}

Coeficiente de variação - 13,39\% 
a percentagem do farelo de algodão como fonte protéica. No período de acabamento, apesar de não haver sido constatado nenhum efeito significativo para análise de regressão, foi obser vada uma tendência de redução de ganhos de peso, principalmente nos tratamentos 4 e 5. Entretanto, o tratamento 3 chegou a superar em 3,4: o tratamento 1 .

Os resultados indicaram que houve um efeito negativo do farelo de algodão sobre o ganho de peso, principalmen te no período de crescimento, parecendo ser em função da diminuição do teor de lisina nas rações, conforme se aumenta a percentagem do farelo de algodão nas mesmas. Apesar de não sig nificativo, este efeito foi maior nos tratamentos 4 e 5 no período de crescimento, sendo de menor intensidade no período de acabamento, possivelmente em razão dos níveis de lisina nas ra ções neste período, estarem mais próximos das recomendações do NRC (1973).

Segundo OSLAGE (1966) in RERAT (1972) a deposição de energia na forma de lipídios é bem mais rápida que a de posição de nitrogênio como proteína, e isso permite supor que a recuperação de ganho de peso dos animais no período de acaba mento, é devido ao ganho compensatório existente, segundo LARSEN e BELL (1967), sendo representado no presente ensaio, riais pela formação de gordura do que pela formação de músculo.

E possível ainda considerar que, segundo HAYS (1968), a falta de um aminoácido essencial reduz a síntese de proteína, e a correção do nível daquele aminoácido na ração em um período futuro, resultaria em uma excessiva deposição de gordura corporal. Diversos autores obtiveram igualmente resultados negativos, quando o farelo de soja foi substituído pelo farelo de algodão, entre os quais WALLACE et alii. (1955), HALE e LYMAN (1957), SEWELL et alii, (1957), HALE et alii (1958), LYMAN (1966), JARQUIN et alii (1968), OSTROWSKI et alii (1969) e MONCADA e MANER (1970).

Apesar da regressão linear ser significativa pa ra o período total, a FIGURA 1 mostra que o valor observado do 


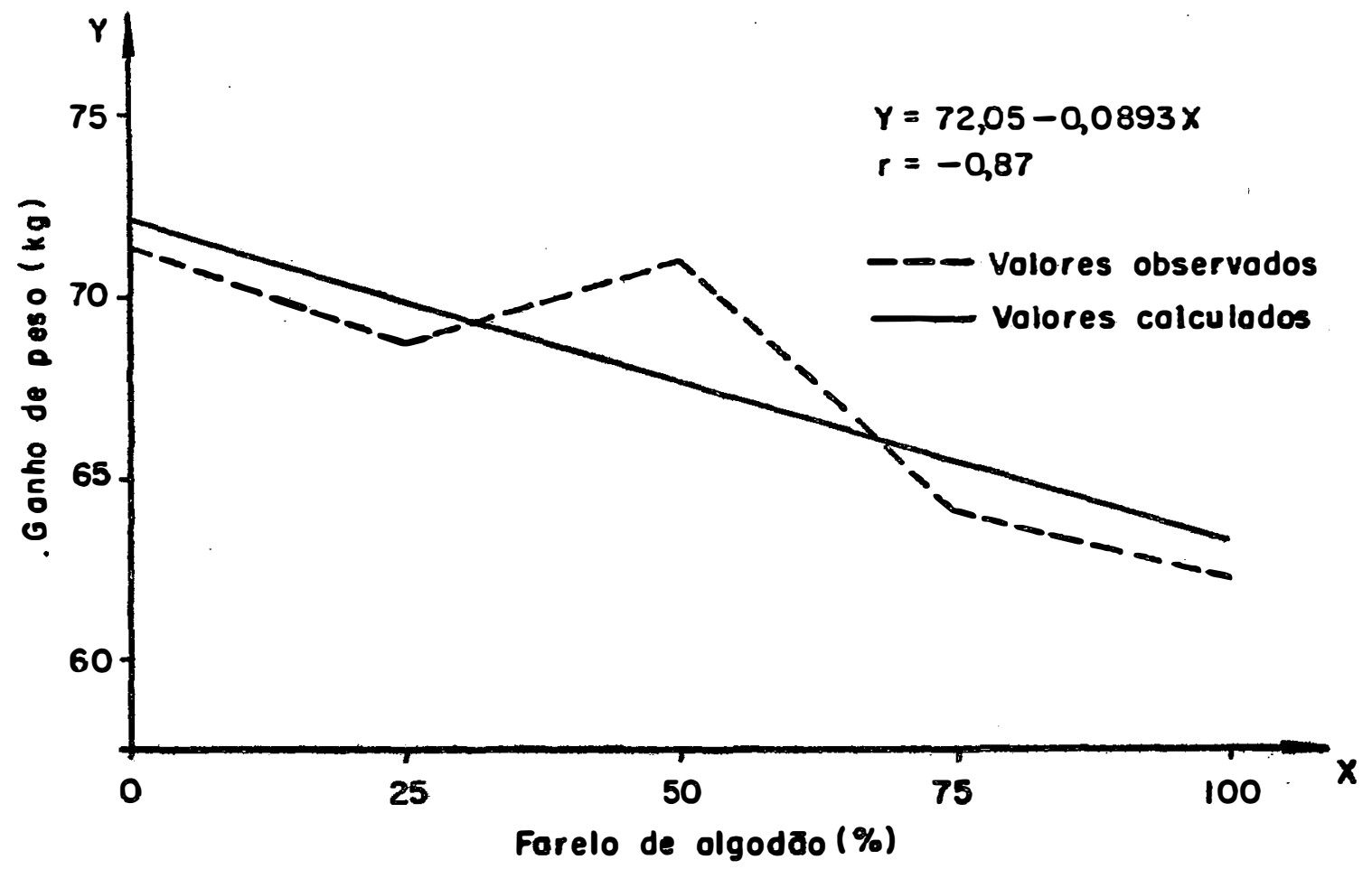

Figuro 1-Efeito dos trotomentos sobre o ganho de peso durante o período totoll 91 dios)

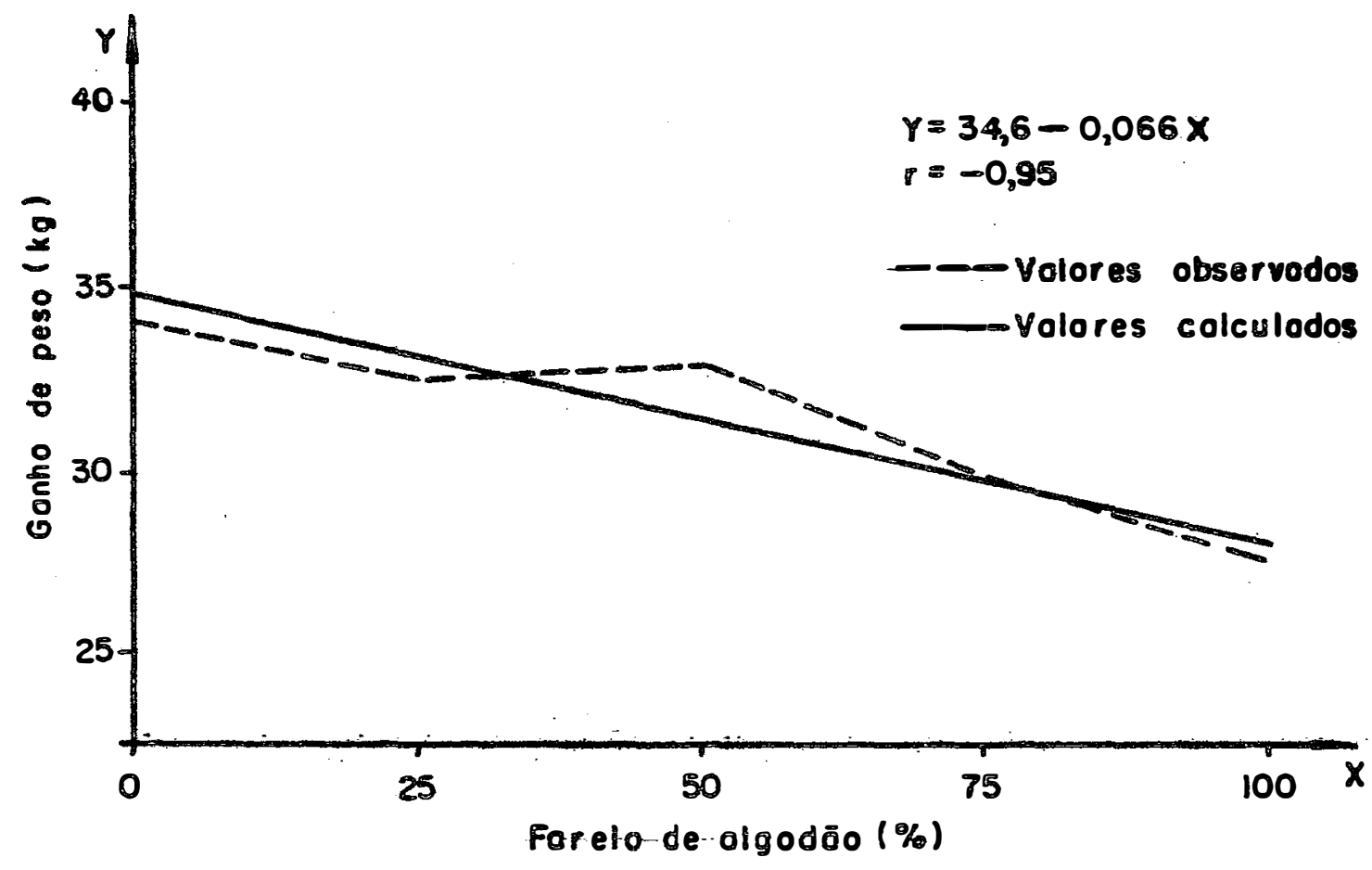

Figuro 2 - Efeî́o dos trofomentos sobre o gonho de peso duron te o periodo de crescimento (42 dios) 
tratamento 3 está situada quase no mesmo ponto do tratamento 1 na ordenada do gráfico. 0 mesmo pode ser visto na FIGURA 2 para o período de crescimento.

Resultados semelhantes foram encontrados, anterior mente, por WALLACE et alii (1958), SEWELL et alii (1957), HALE et alii (1958), OSTROWSKI et alii (1969), MONCADA e MANER (1970) e RODRIGUES (1972).

A eficiência da mistura em partes iguais de farelo de soja e farelo de algodão, parece estar relacionada com um melhor balanceamento em lisina e metionina, pois como pode ser observado na TABELA 4, o farelo de algodão possue um teor ligeiramente maior de metionina que o farelo de soja, e este com pensa parcialmente a deficiência em lisina do farelo de algodão, possuíndo um teor bem mais elevado deste aminoácido.

\subsubsection{Consumo de ração}

Os dados de consumo de ração bem como as respectivas análises de variância durante os períodos total, de cres cimento e de acabamento, podem ser vistos nas TABELAS 15, 16; 17,$18 ; 19,20$; respectivamente. Os consumos individuais por período de 14 dias são apresentados na TABELA $A_{7}$.

Não houve efeito estatísticamente significativo para nenhuma regressão em qualquer período, bem como a análise de variância comum não mostrou diferenças significativas entre os tratamentos.

Resultados semelhantes foram obtidos por WALLACE et alii, (1955), LYMAN (1966), GONZALES e AGUILERA (1967), MONCADA e MANER (1970) e RODRIGUES (1972). Entretanto KORNEGAY (1961) ao adicionar miolo de sementes de algodão a rações possuíndo farelo de soja ou farelo de amendoim como fonte protéica, observou um efeito negativo sobre o consumo, do mesmo modo que JARQUIN et aliii,(1968) trabalhando com rações com baixo ní ve1 de energia observaram um menor consumo devido ao farelo de algodão em rações para suínos em acabamento. 
TABELA 15 - Consumo de Ração (kg) - Período Total 91 dias) - Ensaio I

\begin{tabular}{lrrrrrl}
\hline \multirow{2}{*}{ BLOCOS } & \multicolumn{5}{c}{ TRATAMENTOS } & \multirow{2}{*}{ TOTAL } \\
\cline { 2 - 5 } & \multicolumn{1}{c}{1} & \multicolumn{1}{c}{3} & \multicolumn{1}{c}{4} & \multicolumn{1}{c}{5} & \\
\hline 1 & 254,8 & 235,7 & 264,5 & 292,5 & 220,0 & 1267,5 \\
2 & 202,3 & 241,8 & 256,3 & 245,4 & 223,5 & 1169,4 \\
3 & 218,9 & 251,7 & 200,9 & 192,4 & 216,1 & 1080,0 \\
4 & 217,1 & 218,8 & 221,4 & 237,0 & 242,7 & 1137,0 \\
5 & 279,2 & 220,7 & 233,9 & 202,7 & 237,1 & 1173,6 \\
6 & 223,1 & 227,0 & 237,9 & 199,4 & 269,8 & 1157,2 \\
\hline Total & 1395,4 & 1395,7 & 1414,9 & 1369,5 & 1409,2 & 6984,6 \\
Média & 232,6 & 232,6 & 235,8 & 228,2 & 234,9 & \\
\hline
\end{tabular}

TABELA 16 - Análise de Variância - Consumo de Ração - Período Total Ensaio I

\begin{tabular}{lcrrl}
\hline Causa de Variação & GL & SQ & QM & F \\
\hline Regressão Linear & 1 & 0,03 & 0,03 & 0,00004 \\
Regressão Quadrätica & 1 & 2,40 & 2,40 & 0,003 \\
Regressão Cúbica & 1 & 73,04 & 73,04 & 0,11 \\
Regressão 4 Grau & 1 & 129,48 & 129,48 & 0,20 \\
\hline Tratamentos & 4 & 204,95 & 51,24 & 0,08 \\
Blocos & 5 & 3732,94 & 746,59 & 1,14 \\
Resỉduos & 20 & 13129,16 & 656,46 & \\
\hline TOTAL & 29 & 17067,05 & & \\
\hline
\end{tabular}

Coeficiente de Variação - 11,00\% 
TABEIA 17 - Consuno de Ração (kg) - Período de Crescimento (42 dias) Ensaio I

\begin{tabular}{lrrrrrl}
\hline \multirow{2}{*}{ BLOCOS } & \multicolumn{5}{c}{ TRATAMENTOS } & \multirow{2}{*}{ TOTAL } \\
\cline { 2 - 5 } & \multicolumn{1}{c}{1} & \multicolumn{1}{c}{2} & \multicolumn{1}{c}{3} & \multicolumn{1}{c}{4} & \multicolumn{1}{c}{5} & \\
\hline 1 & 100,1 & 89,7 & 117,2 & 120,6 & 89,4 & 517,0 \\
2 & 80,0 & 100,2 & 102,6 & 101,4 & 70,5 & 454,7 \\
3 & 90,5 & 102,5 & 74,1 & 86,3 & 85,4 & 438,8 \\
4 & 90,0 & 92,2 & 89,5 & 92,5 & 94,5 & 458,7 \\
5 & 110,7 & 88,6 & 93,0 & 77,3 & 95,1 & 464,7 \\
6 & 94,8 & 88,7 & 100,0 & 82,4 & 104,3 & 470,2 \\
\hline Total & 566,1 & 561,9 & 576,4 & 560,5 & 539,2 & 2804,1 \\
Mëdia & 92,7 & 93,6 & 96,1 & 93,4 & 90,0 & \\
\hline
\end{tabular}

TABELA 18 - Análise de variância - Consumo de Ração- Período de Crescimento Ensaio I

\begin{tabular}{lrrrr}
\hline Causa de Variação & GL & SQ & QM & F \\
\hline Regressão Linear & 1 & 50,784 & 50,784 & 0,34 \\
Regressão Quadrática & 1 & 49,680 & 49,680 & 0,34 \\
Regressão Cúbica & 1 & 9,680 & 9,680 & 0,07 \\
Regressão 4 Grau & 1 & 13,074 & 13,074 & 0,09 \\
\hline Tratamentos & 4 & 123,218 & 30,804 & 0,21 \\
Blocos & 5 & 706,043 & 141,209 & 0,96 \\
Resíduos & 20 & 2950,662 & 147,533 & \\
\hline TOTAL & 29 & 3656,705 & & \\
\hline
\end{tabular}

Coeficiente de Variação $=12,99 \%$ 
TABELA 19 - Consumo de Ração (kg) - Período de Acabamento (49 dias) Ensaio I

\begin{tabular}{lcccccc}
\hline \multirow{2}{*}{ BLOCOS } & \multicolumn{5}{c}{ TRATAMENTOS } & \multirow{2}{*}{ TOTAL } \\
\cline { 2 - 6 } & 1 & 2 & 3 & 4 & 5 & \\
\hline 1 & 154,7 & 146,0 & 147,3 & 171,9 & 130,6 & 750,5 \\
2 & 122,3 & 141,6 & 153,7 & 144,1 & 153,0 & 714,7 \\
3 & 128,4 & 149,2 & 126,8 & 106,1 & 130,7 & 641,2 \\
4 & 127,1 & 126,6 & 131,9 & 144,5 & 148,2 & 678,3 \\
5 & 168,5 & 132,1 & 140,9 & 125,4 & 142,0 & 708,9 \\
6 & 128,3 & 138,3 & 137,2 & 117,0 & 165,5 & 686,3 \\
\hline Tota1 & 829,3 & 833,8 & 837,8 & 809,0 & 870,0 & 4179,9 \\
Média & 138,2 & 139,0 & 139,6 & 134,8 & 145,0 & \\
\hline
\end{tabular}

TABELA 20 - Anālise de Variância - Consumo de Ração - Período de Acabamento Ensaio I

\begin{tabular}{lrrrr}
\hline Causa de Variação & GL & SQ & QM & F \\
\hline Regressão Linear & 1 & 53,393 & 53,393 & 0,22 \\
Regressão Quadrätica & 1 & 76,572 & 76,572 & 0,31 \\
Regressão Cúbica & 1 & 135,902 & 135,902 & 0,55 \\
Regressão 4o Grau & 1 & 57,128 & 57,128 & 0,23 \\
\hline Tratamentos & 4 & 322,995 & 80,7488 & 0,33 \\
Blocos & 5 & 1378,847 & 275,7694 & 1,12 \\
Resíduos & 20 & 4933,101 & 246,6551 & \\
\hline TOTAL & 29 & 6634,943 & & \\
\hline
\end{tabular}

Coeficiente de Variação $=11,27 \%$ 


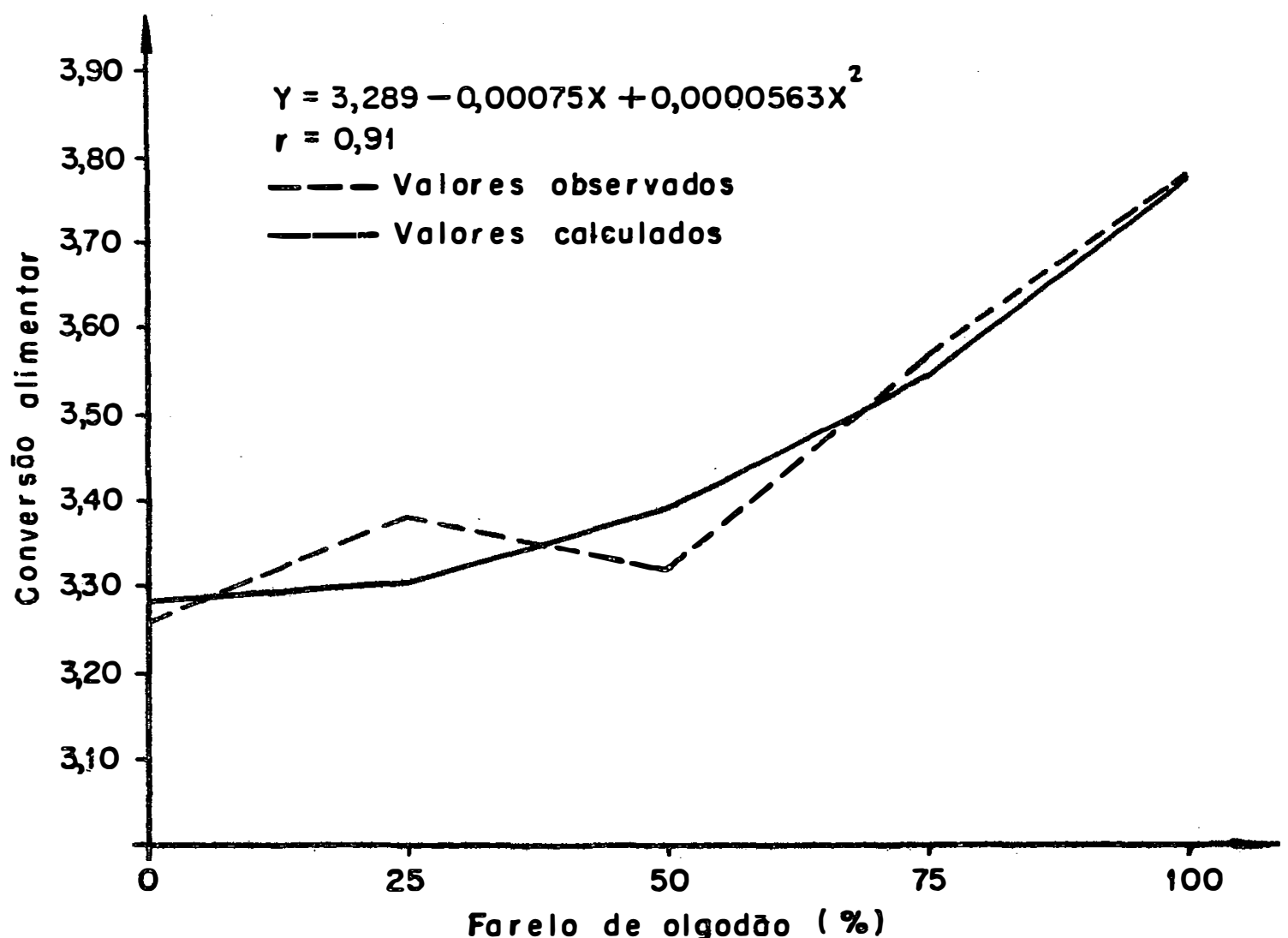

Figuro 3 - Efeito dos trotomentos sobre o conversōo olimentor duronte o período totol (91dios)

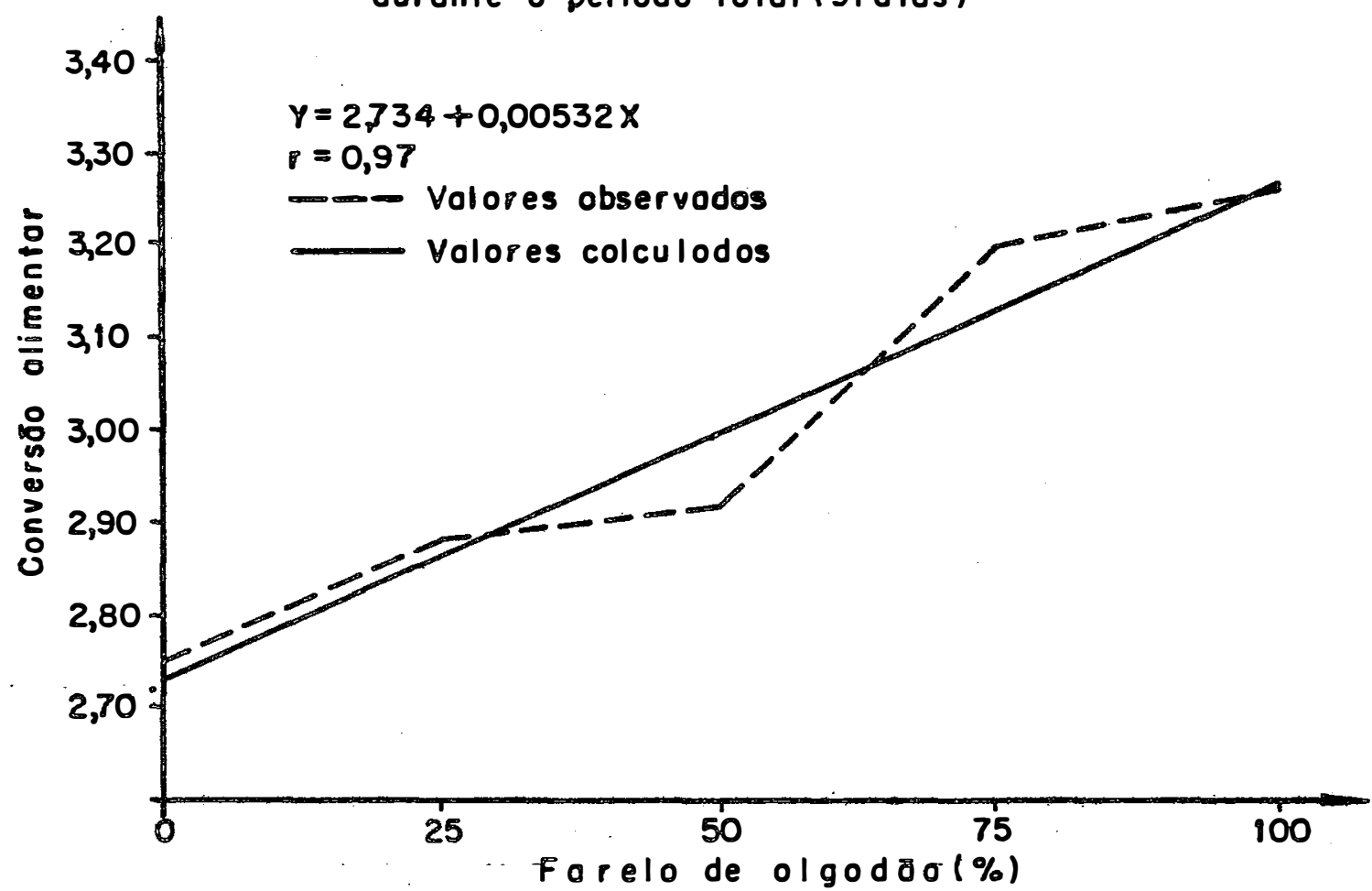

Figuro 4 - Efeito dos trotomentos sobre o conversōo olimentor duronte o periodo de crescimento ( 42 dios) 


\subsubsection{Conversão alimentar}

As TABELAS 21,$22 ; 23,24 ; 25,26$; mostram os re sultados para conversão alimentar, bem como suas análises de variância, obtidos respectivamente para os períodos total, de crescimento e de acabamento. As conversões alimentares individuais por período de 14 dias podem ser vistas na TABELA $A_{8}$.

Nos períodos total e de crescimento as conversões alimentares sofreram um efeito negativo devido ao farelo de a $\underline{1}$ godão.

As regressões quadráticas para o período total e período de acabamento foram estatísticamente significativas $(P<0,05)$ apresentando, respectivamente, as seguintes equações: $\mathrm{Y}=3,289-0,00075 \mathrm{X}+0,00000563 \mathrm{X}^{2}$ e $\mathrm{Y}=3,808-0,00607 \mathrm{X}+$ $0,000099 X^{2}$ onde $Y$ representa o valor da conversão alimentar e $X$ a porcentagem do farelo de algodão. Os gráficos obtidos para os períodos total e de acabamento podem ser observados nas FIGURAS 3 e 5 .

No período de crescimento os resultados de conversão alimentar pioraram com o aumento do percentual de fare10 de algodão nas rações. O efeito foi linear e estatísticamen te significativo $(P<0,01)$, de acordo com a seguinte equação: $Y=2,734+0,00532 X$ (FIGURA 4). E provável que este efeito ne gativo sobre a conversão alimentar deve ter sido causado pela diminuição dos níveis de lisina na ração, decorrente dos aumen tos dos teores de farelo de algodão nos tratamentos 1 a 5 , níveis esses insuficientes para atender as necessidades do referido aminoácido no período de crescimento.

Durante o período de acabamento as exigências percentuais em aminoácidos são menores que no período de crescimento, e as rações com $13 \%$ de proteína bruta apresentaram ní veis de lisina mais próximo das exigências dos suínos naquele período, sendo que provavelmente por este motivo, a regressão tenha sido quadrática e não linear como para o periodo de crescimento. 
TABELA 21 - Conversão Alimentar - Período Total (91 dias) - Ensaio I

\begin{tabular}{|c|c|c|c|c|c|c|}
\hline \multirow{2}{*}{ BLOCOS } & \multicolumn{5}{|c|}{ TRATAMENTOS } & \multirow{2}{*}{ TOTAL } \\
\hline & 1 & 2 & 3 & 4 & 5 & \\
\hline 1 & 3,33 & 3,27 & 3,35 & 3,57 & 3,76 & 17,28 \\
\hline 2 & 3,00 & 3,36 & 3,28 & 3,78 & 3,76 & 17,18 \\
\hline 3 & 3,53 & 3,42 & 3,43 & 3,89 & 4,15 & 18,42 \\
\hline 4 & 3,17 & 3,53 & 3,38 & 3,20 & 3,73 & 17,01 \\
\hline 5 & 3,26 & 3,22 & 3,20 & 3,62 & 3,59 & 16,89 \\
\hline 6 & 3,30 & 3,46 & 3,28 & 3,38 & 3,67 & 17,09 \\
\hline Total & 19,59 & 20,26 & 19,92 & 21,44 & 22,66 & 103,87 \\
\hline Média* & $3,26^{\mathrm{a}}$ & $3,38^{a b}$ & $3,32^{\mathrm{a}}$ & $3,57^{\mathrm{b}}$ & $3,78^{\mathrm{C}}$ & \\
\hline
\end{tabular}

* Letras diferentes diferem estatísticamente ao nível de 5\% pelo teste de Duncan

TABELA 22 - Anālise de Variância - Conversão Alimentar - Período Total Ensaio I

\begin{tabular}{lcccc}
\hline Causa de Variação & GL & SQ & QM & F \\
\hline Regressão Linear & 1 & 0,8930 & 0,8930 & $39,17^{* *}$ \\
Regressão Quadrätica & 1 & 0,1043 & 0,1043 & $4,57^{*}$ \\
Regressão Cübica & 1 & 0,0084 & 0,0083 & 0,36 \\
Regressão 4 Grau & 1 & 0,0602 & 0,0602 & 2,64 \\
\hline Tratamentos & 4 & 1,0660 & 0,2665 & $11,69 *$ \\
Blocos & 5 & 0,3129 & 0,0626 & 2,74 \\
Resíduos & 20 & 0,4551 & 0,0228 & \\
\hline TOTAL & 29 & 1,8340 & & \\
\hline
\end{tabular}

Coeficiente de Variação $=4,36 \%$

** $(\mathrm{P}<0,01)$

* $\quad(P<0,05)$ 
TABELA 23 - Conversão Alimentar - Período de Crescimento (42 dias) Ensaio I

\begin{tabular}{lcccccc}
\hline \multirow{2}{*}{ BLOCOS } & \multicolumn{5}{c}{ TRATAMENTOS } & \multirow{2}{*}{ TOTAL } \\
\cline { 2 - 6 } & 1 & 2 & 3 & 4 & 5 & \\
\hline 1 & 2,94 & 2,80 & 2,93 & 3,26 & 3,37 & 15,30 \\
2 & 2,50 & 2,90 & 2,93 & 3,62 & 3,20 & 15,15 \\
3 & 2,78 & 3,06 & 2,80 & 3,38 & 3,28 & 15,30 \\
4 & 2,65 & 2,88 & 3,03 & 2,85 & 3,26 & 14,67 \\
5 & 2,73 & 2,81 & 2,95 & 3,29 & 3,22 & 15,00 \\
6 & 2,92 & 2,81 & 2,90 & 2,79 & 3,21 & 14,63 \\
\hline Total & 16,52 & 17,26 & 17,54 & 19,19 & 19,54 & 90,05 \\
Media $^{*}$ & $2,75^{\mathrm{a}}$ & $2,88^{\mathrm{a}}$ & $2,92^{\mathrm{a}}$ & $3,20^{\mathrm{b}}$ & $3,26^{\mathrm{b}}$ & \\
\hline
\end{tabular}

* Letras diferentes diferem estatísticamente ao nível de 5\% pelo teste de Duncan

TABELA 24 - Anälise de Variância - Conversão Alinientar - Período de Crescimento - Ensaio I

\begin{tabular}{lcccc}
\hline Causa de Variação & GL & SQ & QM & F \\
\hline Regressão Linear & 1 & 1,0587 & 1,0587 & $25,36^{* *}$ \\
Regressão Quadrätica & 1 & 0,0041 & 0,0041 & 0,10 \\
Regressão Cübica & 1 & 0,0118 & 0,0118 & 0,28 \\
Regressão 4 Grau & 1 & 0,0482 & 0,0482 & 1,15 \\
\hline Tratamentos & 4 & 1,1228 & 0,2807 & $6,71^{* *}$ \\
Blocos & 5 & 0,0896 & 0,0179 & 0,42 \\
Resíduos & 20 & 0,8364 & 0,0418 & \\
\hline TOTAL & 29 & 1,8696 & & \\
\hline
\end{tabular}

Coeficiente de Variação $=6,81 \%$

** $(\mathrm{P}<0,01)$ 
TABELA 25 - Conversão A limentar - Período de Acabamento (49 dias) Ensaio I

\begin{tabular}{|c|c|c|c|c|c|c|}
\hline \multirow{2}{*}{ BLOCOS } & \multicolumn{5}{|c|}{ TRATAMENTOS } & \multirow{2}{*}{ TOTAL } \\
\hline & 1 & 2 & 3 & 4 & 5 & \\
\hline 1 & 3,64 & 3,65 & 3,78 & 3,82 & 4,08 & 18,97 \\
\hline 2 & 3,45 & 3,78 & 3,57 & 3,89 & 4,08 & 18,77 \\
\hline 3 & 4,35 & 3,73 & 3,96 & 4,42 & 5,03 & 21,49 \\
\hline 4 & 3,68 & 4,22 & 3,66 & 3,48 & 4,12 & 19,16 \\
\hline 5 & 3,74 & 3,57 & 3,40 & 3,86 & 3,89 & 18,46 \\
\hline 6 & 3,72 & 4,07 & 3,61 & 3,97 & 4,04 & 19,41 \\
\hline Total & 22,58 & 23,02 & 21,98 & 23,44 & 25,24 & 116,26 \\
\hline Média* & $3,76^{\mathrm{a}}$ & $3,84^{\mathrm{a}}$ & $3,66^{\mathrm{a}}$ & $3,91^{\mathrm{a}}$ & $4,21^{\mathrm{b}}$ & \\
\hline
\end{tabular}

* Letras diferentes diferem estatísticamente ao nível de 5\% pelo teste de Duncan

TABELA 26-Anālise de Variância - Conversão Alimentar - Período de Acabameñ to - Ensaio I

\begin{tabular}{lcccc}
\hline Causa de Variação & GL & SQ & QM & F \\
\hline Regressão Linear & 1 & 0,5491 & 0,5491 & $9,98^{* *}$ \\
Regressão Quadrătica & 1 & 0,3244 & 0,3244 & $5,90^{*}$ \\
Regressão Cübica & 1 & 0,0552 & 0,0552 & 1,00 \\
Regressão 4 Grau & 1 & 0,0897 & 0,0897 & 1,63 \\
\hline Tratamentos & 4 & 1,0184 & 0,2546 & $4,63^{* *}$ \\
Blocos & 5 & 1,1775 & 0,2355 & $4,28^{*}$ \\
Resíduos & 20 & 1,0990 & 0,0550 & \\
\hline TOTAL & 29 & 3,2949 & & \\
\hline
\end{tabular}

Coeficiente de Variação $=6,05^{\circ}$

** $(\mathrm{P}<0,01)$

* $(\mathrm{P}<0,05)$ 


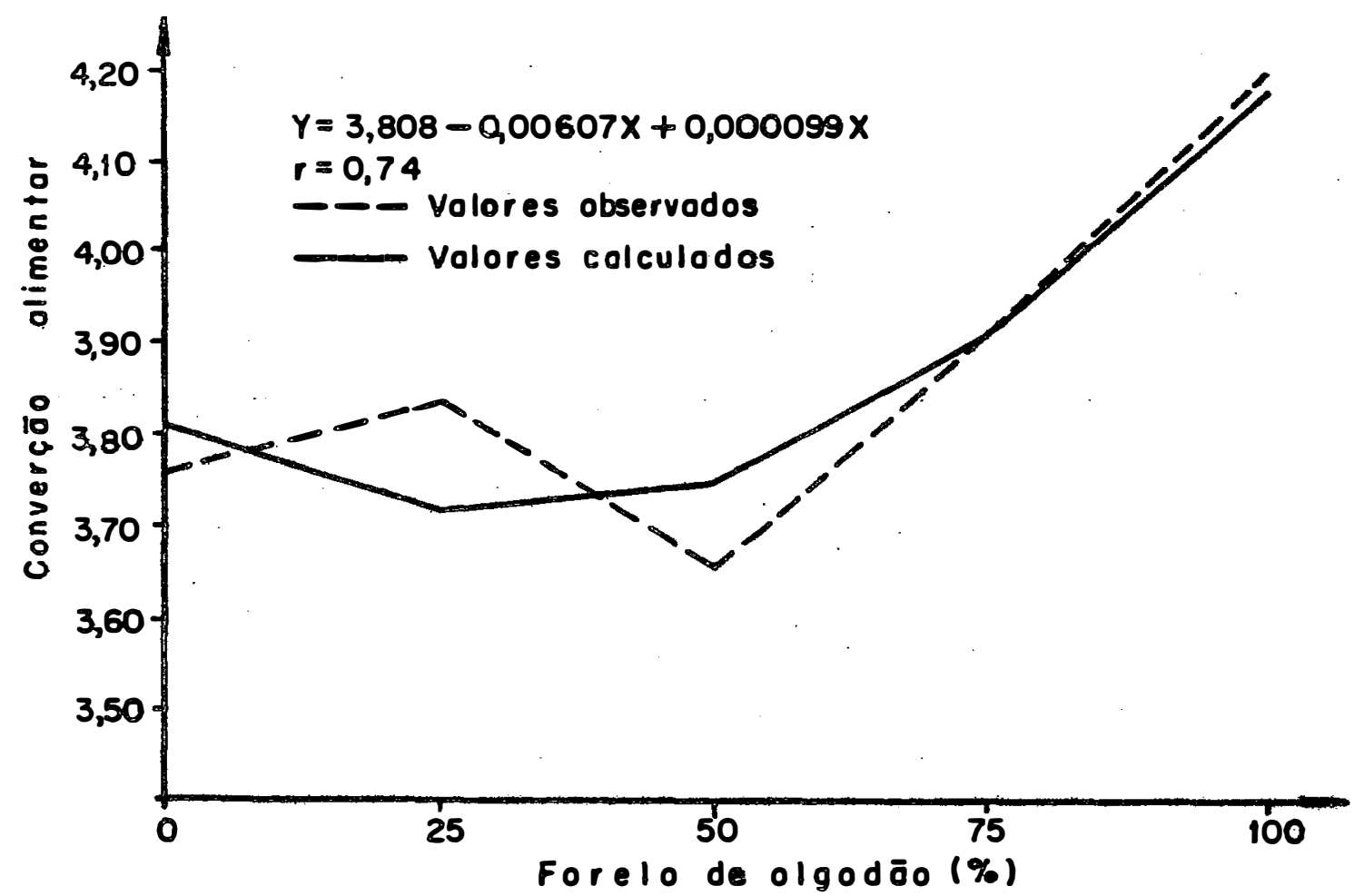

Figuro 5 - Efeito dos frofomentos sobre o conversāo olimentor

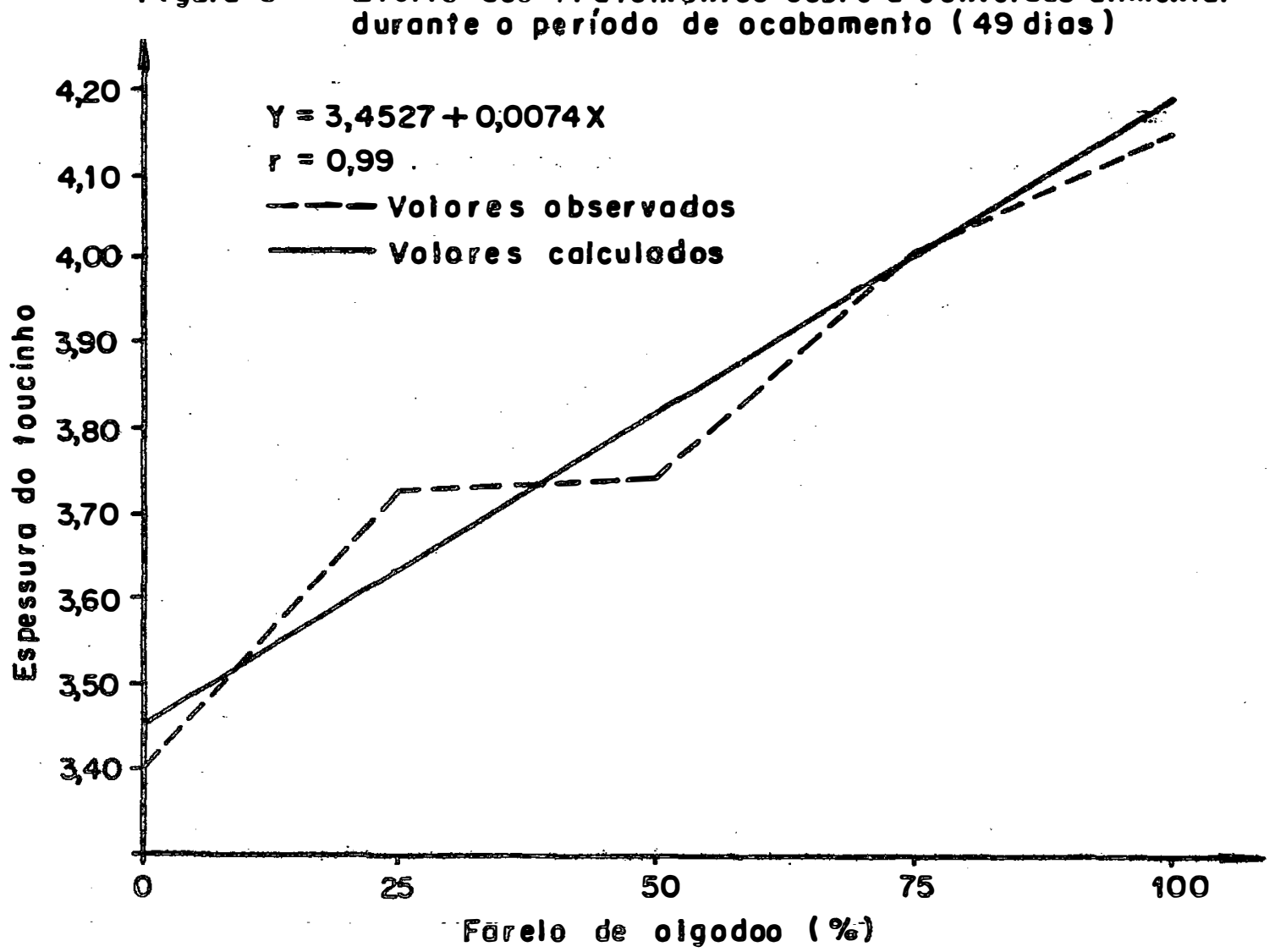

Figura 6 - Epeito dos irofomentos sobre a espessura do foucinho 
e de crescimento.

As diferenças das médias dos tratamentos 4 e 5 no período de crescimento foram estatisticamente significativas $(\mathrm{P}<0,05)$ das médias dos demais tratamentos, enquanto que no período de acabamento somente a média do tratamento 5 diferiu dos demais $(\mathrm{P}<0,05)$, o que vem mostrar o efeito negativo do farelo de algodão, em altas porcentagens na ração, sobre a conversão alimentar.

Diversos outros autores também observaram um efei to negativo do uso do farelo de algodão em relação a conversão alimentar dos suínos, entre eles WALLACE et alii. (1955), HALE e LYMAN (1957), SEWELL et alii. (1957), HALE et alii. (1958), BELL e LARSEN (1967), JARQUIN et alii. (1968), NOLAND et alii. (1968) e MONCADA e MANER (1970).

Entretanto RODRIGUES (1972) não encontrou diferenças estatísticamente significativas para conversão alimentar, com rações de suínos em crescimento e acabamento possuíndo 0, 50 e $100 \%$ de farelo de algodão como fonte protéica.

No período de acabamento houve um efeito de blo$\cos (\mathrm{P}<0,05)$, o que se justifica o delineamento utilizado de blo cos ao acaso.

\subsubsection{Qualidade da carcaça}

A qualidade das carcaças foram avaliadas segundo o Método Brasileiro de Avaliação de Carcaças adotado pela ABCS (1973), e os valores observados, bem como as anảlises de variân cia do rendimento de carcaça, espessura do toicinho, percentagem de pernil, área do olho de lombo e comprimento de carcaça, podem ser vistos nas TABELAS 27 e $28 ; 29$ e $30 ; 31$ e 32; 33 e 34 ; 35 e 36 , respectivamente.

A TABELA $A_{9}$ mostra os dados auxiliares para obtenção das características de carcaças estudadas. 
TABELA 27 - Rendimento de Carcaça $\left(\frac{0}{0}\right)$ - Ensaio I

\begin{tabular}{lrrrrrr}
\hline \multirow{2}{*}{ BLOCOS } & \multicolumn{5}{c}{ TRATAMENTOS } & \multirow{2}{*}{ TOTAL } \\
\cline { 2 - 5 } & \multicolumn{1}{c}{1} & \multicolumn{1}{c}{3} & \multicolumn{1}{c}{4} & \multicolumn{1}{c}{5} & \\
\hline 1 & 78,40 & 78,40 & 78,60 & 79,30 & 80,90 & 395,60 \\
2 & 81,60 & 81,00 & 79,70 & 81,00 & 76,30 & 399,60 \\
3 & 78,40 & 78,40 & 81,50 & 80,20 & 77,70 & 436,20 \\
\hline Tota1 & 238,40 & 237,80 & 239,80 & 240,50 & 234,90 & 1191,40 \\
Média & 79,47 & 79,27 & 79,93 & 80,17 & 78,30 & \\
\hline
\end{tabular}

TABELA 28 - Análise de Variância - Rendimento de Carcaça - Ensaio I

\begin{tabular}{lcccc}
\hline Causa de Variação & GL & SQ & QM & F \\
\hline Regressão Linear & 1 & 0,62 & 0,62 & 0,19 \\
Regressão Quadrätica & 1 & 3,04 & 3,04 & 0,93 \\
Regressão Cúbica & 1 & 2,64 & 2,64 & 0,80 \\
\hline Tratamentos & 4 & 6,30 & 1,58 & 0,48 \\
Bloco & 2 & 1,89 & 0,94 & 0,28 \\
Resíduo & 8 & 26,30 & 3,29 & \\
\hline TOTAL & 14 & 34,49 & & \\
\hline
\end{tabular}

Coeficiente de Variação $=2,28 \%$ 
TABELA 29 - Espessura do Toicinho (cm) - Ensaio I

\begin{tabular}{lrrrrrr}
\hline \multirow{2}{*}{ BLOCOS } & \multicolumn{7}{c}{ TRATAMENTOS } & \multirow{2}{*}{ TOTAL } \\
\cline { 2 - 5 } & \multicolumn{1}{c}{1} & 2 & 3 & \multicolumn{1}{c}{4} & \multicolumn{1}{c}{5} & \\
\hline 1 & 3,99 & 3,17 & 3,48 & 3,83 & 3,56 & 18,03 \\
2 & 3,30 & 3,96 & 4,06 & 4,44 & 4,44 & 20,20 \\
3 & 2,92 & 4,06 & 3,68 & 4,01 & 4,44 & 19,11 \\
\hline Total & 10,21 & 11,19 & 11,22 & 12,28 & 12,44 & 57,34 \\
Media & 3,40 & 3,73 & 3,74 & 4,09 & 4,15 & \\
\hline
\end{tabular}

TABELA 30 - Análise de Variância - Espessura do Toicinho - Ensaio I

\begin{tabular}{lcccc}
\hline Causa de ariação & GL & SQ & QM & F \\
\hline Regressão Linear & 1 & 1,0267 & 1,0267 & $5,55^{*}$ \\
Desvios da Regressão & 3 & 0,0683 & 0,0228 & 0,14 \\
\hline Tratamentos & 4 & 1,1085 & 0,2771 & 1,49 \\
Blocos & 2 & 0,4709 & 0,2354 & 1,27 \\
Resíduos & 8 & 1,4793 & 0,1849 & \\
\hline TOTAL & 14 & 3,0587 & & \\
\hline
\end{tabular}

Coeficiente de Variação $=11,25 \%$

* $(\mathrm{P}<0,05)$ 
TABELA 31 - Percentagem de Pérnil - Ensaio I

\begin{tabular}{lllllll}
\hline \multirow{2}{*}{ BLOCOS } & \multicolumn{7}{c}{ TRATAMENTOS } & \multirow{2}{*}{ TOTAL } \\
\cline { 2 - 5 } & \multicolumn{1}{c}{1} & 2 & 3 & 4 & 5 & \\
\hline 1 & 13,07 & 13,71 & 13,32 & 12,84 & 11,50 & 64,44 \\
2 & 13,58 & 13,35 & 13,15 & 12,96 & 12,40 & 65,44 \\
3 & 12,69 & 13,20 & 12,07 & 12,27 & 11,98 & 62,21 \\
\hline Total & 39,34 & 40,26 & 38,54 & 38,07 & 35,88 & 192,09 \\
Media $^{*}$ & $13,11^{\text {ab }}$ & $13,42^{\mathrm{a}}$ & $12,85^{\text {ab }}$ & $12,69 \mathrm{~b}$ & $11,96^{\mathrm{c}}$ & \\
\hline
\end{tabular}

* Letras diferentes diferem estatísticamente ao nível de 5\% pelo teste de Duncan

TABELA 32 - Anālise de Variância - Percentagem de Pernil - Ensaio I

\begin{tabular}{llccc}
\hline Causa de Variação & GL & SQ & QM & F \\
\hline Regressão Linear & 1 & 2,7664 & 2,7664 & $21,30 * *$ \\
Regressão Quadrãtica & 1 & 0,5881 & 0,5881 & 4,53 \\
Regressão Cübica & 1 & 0,0282 & 0,0282 & 0,22 \\
Regressão 4 Grau & 1 & 0,2241 & 0,2241 & 1,72 \\
\hline Tratamentos & 4 & 3,6069 & 0,9017 & $6,94^{*}$ \\
Blocos & 2 & 1,0938 & 0,5469 & 4,21 \\
Resíduos & 8 & 1,0391 & 0,1299 & \\
\hline TOTAL & 14 & 5,7398 & & \\
\hline
\end{tabular}

Coeficiente de Variação $=2,81 \%$

** $(\mathrm{P}<0,01)$

* $(\mathrm{P}<0,05)$ 
Os resultados não mostraram qualquer efeito significativo do aumento da percentagem do farelo de algodão sobre o rendimento e o comprimento da carcaça.

No tocante a espessura do toicinho houve um efei to linear estatísticamente significativo $(P<0,05)$, mas a análise de variância comum não apresentou nenhuma significância entre os tratamentos. A equação de regressão foi: $Y=3,4527+$ $0,0074 X$ (FIGURA 6), onde $Y$ vem a ser a espessura do toicinho em $\mathrm{cm}$ e $\mathrm{X}$ a percentagem do farelo de algodão na ração. A espessura do toicinho aumentou conforme o aumento da percentagem de fare10 de algodão na ração.

Do mesmo modo, para a percentagem de pernil e ärea do olho de 1 ombo também foram observados efeitos lineares, dimi nuindo a percentagem de pernil e área do olho de lombo em função do aumento percentual do farelo de algodão como fonte protéica na ração. As equações de regressão foram: $\quad Y=13,414$ $0,01216 \mathrm{X}(\mathrm{P}<0,01)$ onde $\mathrm{Y}$ vem a ser a percentagem do pernil e $\mathrm{X}$ a percentagem do fare10 de a1godão na ração, e $Y=31,88-0,0621 X$ $(\mathrm{P}<0,01)$ onde $\mathrm{Y}$ vem a ser a ârea do olho de 1 ombo em $\mathrm{cm}^{2}$ e $X$ a percentagem de farelo de algodão como fonte protéica. As FIGURAS 7 e 8 mostram os gráficos das equações de regressão acima mencionadas.

Ao aplicar o teste de Duncan sobre as médias obti das, foi observado um efeito negativo significativo $(P<0,05)$ em relação a média de percentagem do pernil no tratamento 5 , diferindo das mêdias dos demais tratamentos.

0 teste de Duncan indicou um efeito negativo do a1to nível do farelo de algodão na ração do tratamento 5 , sobre a ärea do olho de lombo como mostra a TABELA 33, onde este tratamento diferiu significativamente dos demais tratamentos.

Os resultados estatisticamente significativos das características de carcaças analisados no presente ensaio, indi caram que a qualidade da carcaça piorou com os aumentos dos teo res de farelo de algodão na ração, o que pode ser explicado pela diminuição dos níveis de lisina. BROWN et alii (1973) mostra 
TABELA 33 - Área do Olho de Lombo $\left(\mathrm{cm}^{2}\right)$ - Ensaio I

\begin{tabular}{lcccccc}
\hline \multirow{2}{*}{ BLOCOS } & \multicolumn{5}{c}{ TRATAMENTOS } & \multirow{2}{*}{ TOTAL } \\
\cline { 2 - 5 } & 1 & 2 & 3 & 4 & 5 & \\
\hline 1 & 29,70 & 32,00 & 29,60 & 33,00 & 23,80 & 148,10 \\
2 & 32,50 & 27,80 & 27,95 & 27,90 & 22,80 & 138,95 \\
3 & 33,50 & 29,10 & 28,30 & 28,30 & 26,05 & 145,25 \\
\hline Tota1 & 95,70 & 88,90 & 85,85 & 89,20 & 72,65 & 432,30 \\
Media $^{*}$ & $31,90^{\mathrm{a}}$ & $29,63^{\mathrm{a}}$ & $28,62^{\mathrm{a}}$ & $29,73^{\mathrm{a}}$ & $24,22^{\mathrm{b}}$ & \\
\hline
\end{tabular}

* Letras diferentes diferem estatísticamente ao nível de $5 \%$ pelo teste de Duncan

TABELA 34 - Anälise de Variância - Ârea do Olho de Lombo - Ensaio I

\begin{tabular}{llrrc}
\hline Causa de Variação & GL & SQ & \multicolumn{1}{c}{ QM } & \multicolumn{1}{c}{ F } \\
\hline Regressão Linear & 1 & 69,921 & 69,921 & $17,83^{* *}$ \\
Regressão Quadrätica & 1 & 4,086 & 4,086 & 1,04 \\
Regressão Cúbica & 1 & 18,644 & 18,644 & 4,75 \\
Regressão 4 Grau & 1 & 3,991 & 3,991 & 1,02 \\
\hline Tratamentos & 4 & 96,642 & 24,161 & $6,16^{*}$ \\
Blocos & 2 & 8,769 & 4,385 & 1,12 \\
Resíduos & 8 & 31,378 & 3,922 & \\
\hline TOTAL & 14 & 136,789 & & \\
\hline
\end{tabular}

Coeficiente de variação $=2,81^{\circ}$

** $(\mathrm{P}<0,01)$

* $(\mathrm{P}<0,05)$ 
TABELA 35 - Comprimento da Carcaça (cm) - Ensaio I

\begin{tabular}{lcccccc}
\hline \multirow{2}{*}{ BLOCOS } & \multicolumn{5}{c}{ TRATAMENTOS } & \multirow{2}{*}{ TOTAL } \\
\cline { 2 - 5 } & 1 & 2 & 3 & 4 & 5 & \\
\hline 1 & 94 & 94 & 98 & 96 & 94 & 476 \\
2 & 96 & 99 & 97 & 95 & 95 & 482 \\
3 & 96 & 90 & 93 & 95 & 94 & 468 \\
\hline Total & 286 & 283 & 288 & 286 & 283 & 1426 \\
Media & 95,3 & 94,3 & 96,0 & 95,3 & 94,3 & \\
\hline
\end{tabular}

TABELA 36 - Análise de Variância - Comprimento da Carcaça - Ensaio I

\begin{tabular}{llccc}
\hline Causa de variação & GL & SQ & QM & F \\
\hline Regressão Linear & 1 & 0,30 & 0,30 & 0,06 \\
Regressão Quadrática & 1 & 1,17 & 1,17 & 0,24 \\
Regressão Cúbica & 1 & 2,70 & 2,70 & 0,55 \\
Regressão 4 Grau & 1 & 2,10 & 2,10 & 0,43 \\
\hline Tratamentos & 4 & 6,26 & 1,56 & 0,32 \\
Blocos & 2 & 19,73 & 9,86 & 2,03 \\
Resíduos & 8 & 38,94 & 4,86 & \\
\hline TOTAL & 14 & 64,94 & & \\
\hline
\end{tabular}

Coeficiente de variação $=2,3 \%$ 


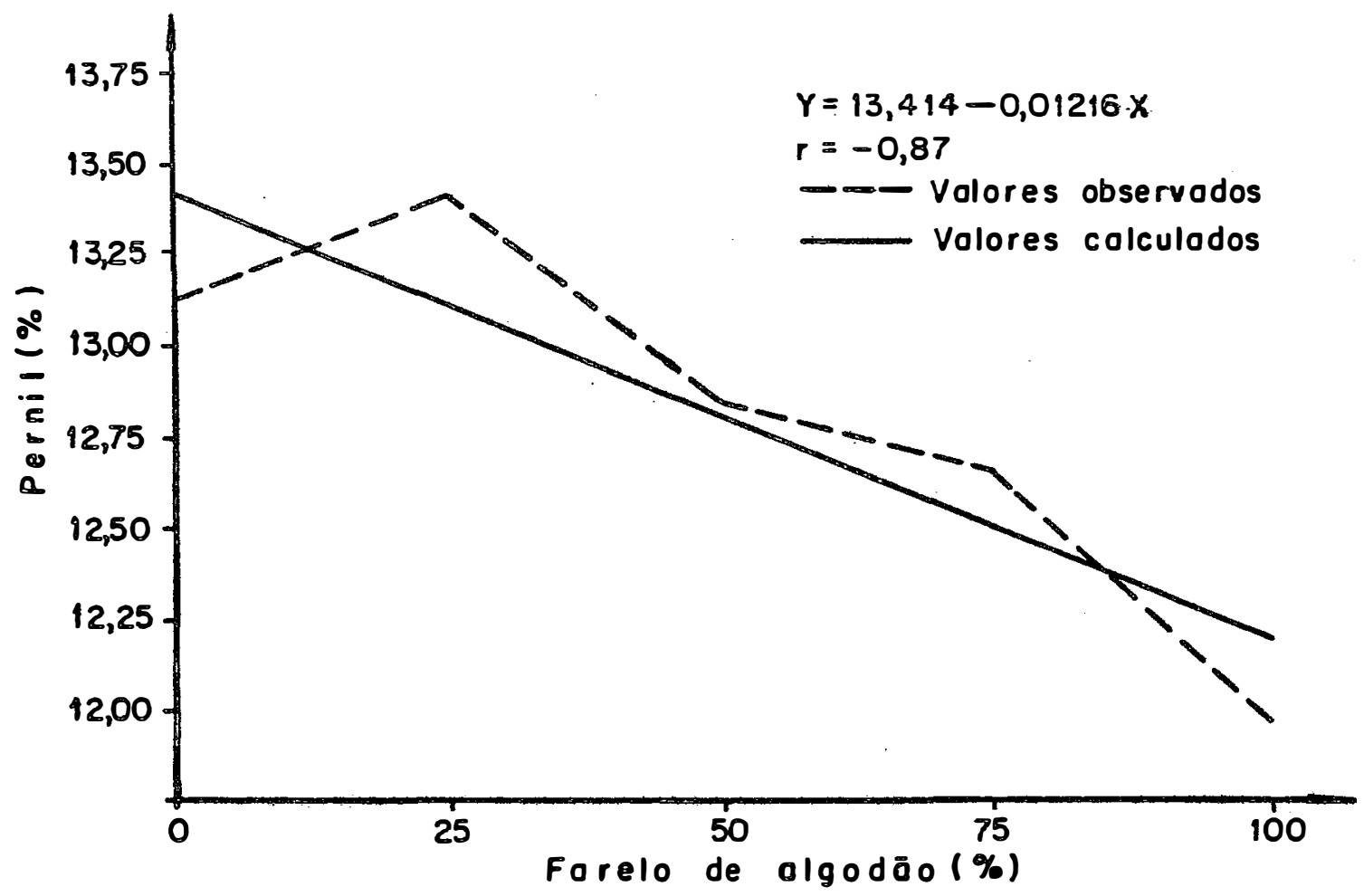

Figuro 7 - Efeito dos tratomenios sobre o pernil

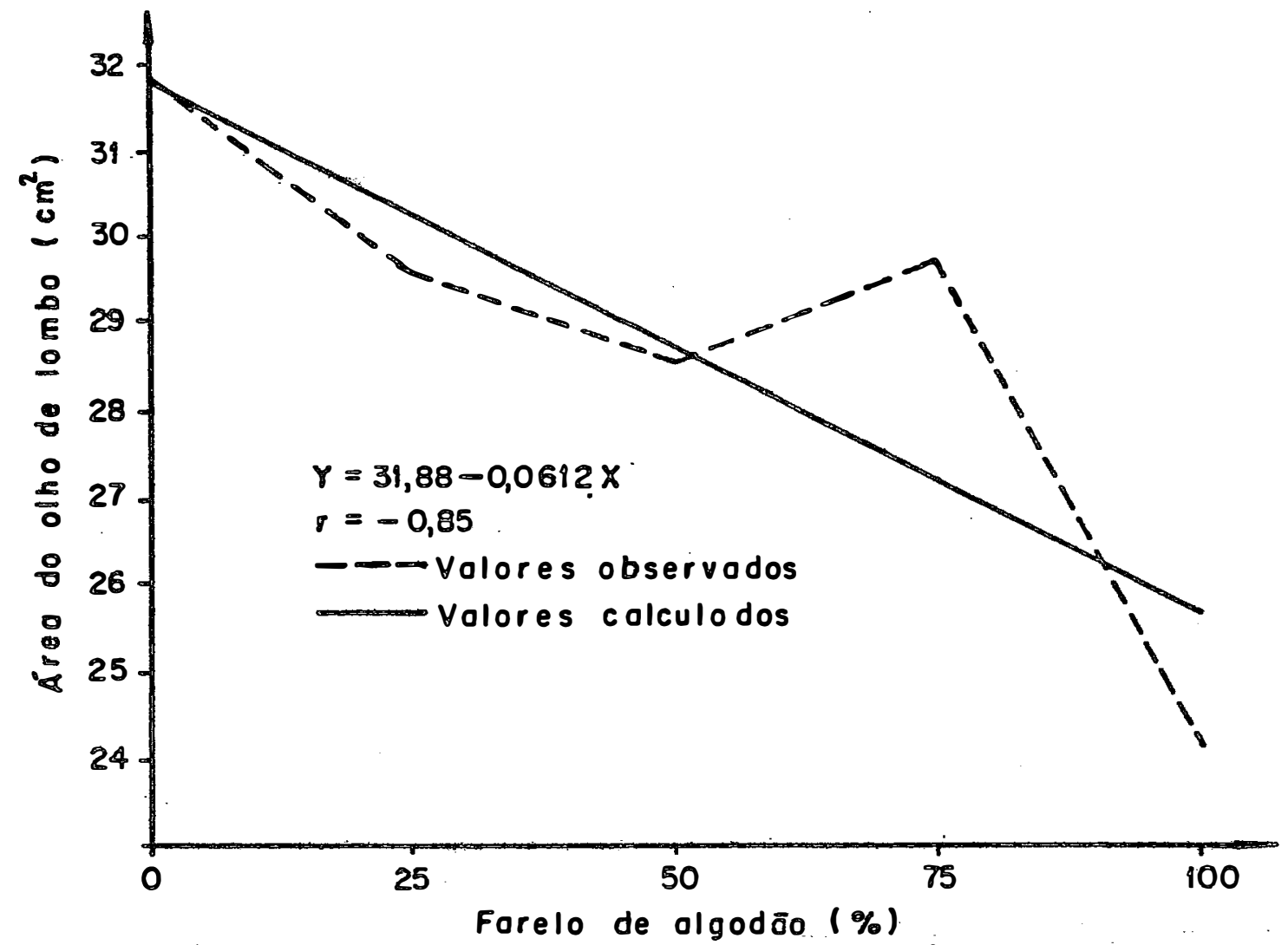

Figura 8 - Efeito dos trołamentos sobre a órea do oltro de lombo 
ram ser a ärea do olho de lombo, a característica de carcaça mais sensível a uma variação de teor de lisina na ração de suínos. Os resultados para espessura do toicinho e área de olho de lombo do presente ensaio estão de acordo com as obser vações de MAGRUDER et alii (1961) que notaram um aumento signifí cativo $(\mathrm{P}<0,05)$ da ârea do olho de $10 \mathrm{mbo}$, e uma tendência de diminuir a espessura do toicinho com a adição de $0,1 \%$ de lisina em rações para suínos em crescimento e acabamento.

A pior qualidade da carcaça observada, no presente ensaio, dos animais submetidos aos tratamentos com maiores per centagens do farelo de algodão, pode ainda ser explicada por HAYS (1968) o qual afirma que havendo deficiência nutricional no período de crescimento, e posterior correção da deficiência durante o período de acabamento, isso resulta em uma excessiva deposi ção de gordura, e consequentemente em maior espessura do toicinho e menor área do olho de lombo.

OSLAGE (1966) in RERAT (1972) observou que os ani mais jovens pesando $25 \mathrm{~kg}$, apresentaram uma eficiência de retenção de nitrogênio da ordem de $52 \%$, justamente quando no presente ensaio, os niveis de lisina das rações com maiores percentagem de farelo de algodão estavam abaixo da exigência normal, principalmente nos tratamentos 4 e 5. A mesma deficiência de lisina não ocorreu no período de acabamento quando, de acordo com os mesmos autores, a capacidade de retenção do nitrogênio diminuiu para $35 \%$. Considerando que no período de acabamento ocorre maior formação de gordura, parece ser a deficiência de lisina na fase de crescimento a maior responsável pela pior qualidade da carcaça.

Durante o transcorrer do período experimental, não foram observados, em nenhum animal, os sintomas externos de into xicação por gossipol, conforme descritos por SMITH (1957) e LYMAN e WIDMER (1966).

\subsection{Ensaio II.}


TABELA 37 - Ganho de Peso (kg) - Período Total (91 dias) - Ensaio II

\begin{tabular}{|c|c|c|c|c|c|c|c|c|}
\hline \multirow{2}{*}{ BLOCOS } & \multicolumn{7}{|c|}{ TRATAMENTOS } & \multirow{2}{*}{ TOTAL } \\
\hline & 1 & 2 & 3 & 4 & 5 & 6 & 7 & \\
\hline 1 & 74,5 & 47,5 & 72,5 & 66,0 & 59,0 & 68,5 & 72,0 & 460,0 \\
\hline 2 & 81,5 & 39,5 & 63,5 & 80,5 & 81,0 & 82,0 & 80,5 & 508,5 \\
\hline 3 & 81,5 & 46,0 & 71,5 & 81,5 & 74,0 & 76,0 & 74,5 & 505,0 \\
\hline 4 & 78,5 & 40,0 & 53,5 & 65,5 & 53,5 & 78,0 & 75,5 & 444,5 \\
\hline $\begin{array}{l}\text { Total } \\
\text { Média* }\end{array}$ & $\begin{array}{r}316,0 \\
79,0^{\mathrm{a}}\end{array}$ & $\begin{array}{r}173,0 \\
43,2^{d}\end{array}$ & $\begin{array}{r}261,0 \\
65,2^{c}\end{array}$ & $\begin{array}{r}293,5 \\
73,4^{\text {ab }}\end{array}$ & $\begin{array}{l}267,5 \\
66,9^{b c}\end{array}$ & $\begin{array}{c}304,5 \\
76,1\end{array}$ & $\begin{array}{c}302,5 \\
75,6^{\text {ab }}\end{array}$ & 1918,0 \\
\hline
\end{tabular}

* Letras diferentes diferem estatísticamente ao nível de $5 \%$ pelo teste de Duncan

TABELA 38 - Anälise de Variância - Ganho de Peso - Período Total - Ensaio II

\begin{tabular}{lrrrc}
\hline Causa de variação & GL & \multicolumn{1}{c}{ SQ } & QM & F \\
\hline$(1) \times(2,3,4,5,6,7)$ & 1 & 514,50 & 514,50 & $12,64^{* *}$ \\
$(2,3,4) \times(5,6,7)$ & 1 & 900,38 & 900,38 & $22,13^{* *}$ \\
Regressão Linear $(2,3,4)$ & 1 & $1.815,03$ & $1.815,03$ & $44,61^{* *}$ \\
Regressão Quadrätica $(2,3,4)$ & 1 & 128,34 & 128,34 & 3,15 \\
Regressão Linear $(5,6,7)$ & 1 & 153,13 & 153,13 & 3,76 \\
Regressão Quadrätica $(5,6,7)$ & 1 & 63,38 & 63,38 & 1,56 \\
\hline Tratamentos & 6 & $3.574,75$ & 595,79 & $14,64^{* *}$ \\
Blocos & 3 & 442,35 & 147,45 & $3,62^{*}$ \\
Resíduos & 18 & 732,40 & 40,69 & \\
\hline TOTAL & 27 & $4.749,50$ & & \\
\hline
\end{tabular}

Coeficiente de variação $=9,3 \%$

** $(\mathrm{P}<0,01)$

* $(\mathrm{P}<0,05)$ 
TABela 39 - Ganho de Peso (kg) - Período de Crescimento (56 dias) Ensaio II

\begin{tabular}{|c|c|c|c|c|c|c|c|c|}
\hline \multirow{2}{*}{ BLOCOS } & \multicolumn{7}{|c|}{ TRATAMENTOS } & \multirow{2}{*}{ TOTAL } \\
\hline & 1 & 2 & 3 & 4 & 5 & 6 & 7 & \\
\hline 1 & 41,0 & 21,5 & 40,0 & 41,5 & 28,5 & 40,5 & 39,0 & 252,0 \\
\hline 2 & 48,5 & 22,0 & 30,5 & 45,0 & 45,0 & 45,5 & 46,5 & 283,0 \\
\hline 3 & 45,5 & 27,5 & 41,0 & 46,0 & 46,0 & 44,5 & 40,0 & 286,5 \\
\hline 4 & 45,0 & 19,5 & 27,0 & 36,5 & 30,5 & 42,0 & 44,5 & 245,0 \\
\hline Total & 180,0 & 90,5 & 138,5 & 169,0 & 146,0 & 172,5 & 170,0 & $1.066,5$ \\
\hline Média* & $45,0^{\mathrm{a}}$ & $22,6^{\mathrm{d}}$ & $34,6^{c}$ & $42,2^{\mathrm{a}}$ & $36,5^{b}$ & $43,1^{\mathrm{a}}$ & $42,5^{\mathrm{a}}$ & \\
\hline
\end{tabular}

* Letras diferentes diferem estatísticamente ao nível de 5\% pelo teste de Duncan

TABELA 40 - Análise de Variância - Ganho de Peso - Período de Cr̃escimento Ensaio II

\begin{tabular}{lcccc}
\hline Causa de variação & GL & SQ & QM & F \\
\hline$(1) \times(2,3,4,5,6,7)$ & 1 & 222,87 & 222,87 & $11,97^{* *}$ \\
$(2,3,4) \times(5,6,7)$ & 1 & 341,26 & 341,26 & $18,33^{* *}$ \\
Regressão Linear $(2,3,4)$ & 1 & 770,28 & 770,28 & $41,37^{* *}$ \\
Regresão Quadrätica $(2,3,4)$ & 1 & 12,76 & 12,76 & 0,68 \\
Regressão Linear $(5,6,7)$ & 1 & 72,00 & 72,00 & 3,87 \\
Regressão Quadrätica $(5,6,7)$ & 1 & 35,04 & 35,04 & 1,88 \\
\hline Tratamentos & 6 & $1.454,214$ & 242,214 & $13,14^{* *}$ \\
Blocos & 3 & 185,098 & 61,999 & $3,33^{*}$ \\
Resíduos & 18 & 335,214 & 18,623 & \\
\hline TOTAL & 27 & $1,974,52$ & & \\
\hline
\end{tabular}

Coeficiente de variação $=11,3 \%$

** $(\mathrm{P}<0,01)$

* $\quad(\mathrm{P}<0,05)$ 
TABELA 41 - Ganho de Peso (kg) - Período de Acabamento (35 dias) Ensaio II

\begin{tabular}{lcccccccc}
\hline \multirow{2}{*}{ BLOCOS } & \multicolumn{7}{c}{ TRATAMENTOS } & \multirow{2}{*}{ TOTAL } \\
\cline { 2 - 7 } & 1 & 2 & 3 & 4 & 5 & 6 & 7 & \\
\hline 1 & 33,5 & 26,0 & 32,5 & 24,5 & 30,0 & 28,0 & 33,0 & 208,0 \\
2 & 33,0 & 17,5 & 33,0 & 35,5 & 36,0 & 36,5 & 34,0 & 225,5 \\
3 & 36,0 & 18,5 & 30,5 & 35,5 & 32,0 & 31,5 & 34,5 & 218,5 \\
4 & 33,5 & 20,5 & 26,5 & 29,0 & 23,0 & 36,0 & 31,0 & 199,5 \\
\hline Total $^{136,0}$ & 82,5 & 122,5 & 124,5 & 121,5 & 132,0 & 132,5 & 851,5 \\
Media $^{*} 34,0^{\text {a }}$ & $20,6^{\mathrm{b}}$ & $30,6^{\mathrm{a}}$ & $31,1^{\mathrm{a}}$ & $30,3^{\mathrm{a}}$ & $33,0^{\mathrm{a}}$ & $33,1^{\mathrm{a}}$ &
\end{tabular}

* Letras diferentes diferem estatísticamente ao nível de $5 \%$ pelo teste de Duncan

TABELA 42 - Anålise de Variância - Ganho de Peso - Período de Acabamento Ensaio II

\begin{tabular}{lcrrc}
\hline Causa de variação & GL & \multicolumn{1}{c}{ SQ } & QM & F \\
\hline$(1) \times(2,3,4,5,6,7)$ & 1 & 60,10 & 60,10 & 4,33 \\
$(2,3,4) \times(5,6,7)$ & 1 & 133,00 & 133,00 & $9,59^{* *}$ \\
Regressão Linear $(2,3,4)$ & 1 & 220,50 & 220,50 & $15,89^{* *}$ \\
Regressão Quadrätica $(2,3,4)$ & 1 & 60,17 & 60,17 & 4,34 \\
Regressão Linear $(5,6,7)$ & 1 & 15,13 & 15,13 & 1,09 \\
Regressão Quadrätica $(5,6,7)$ & 1 & 4,17 & 4,17 & 0,30 \\
\hline Tratamentos & 6 & 493,089 & 82,181 & $5,92^{* *}$ \\
Blocos & 3 & 56,241 & 18,747 & 1,35 \\
Resíduos & 18 & 249,696 & 13,872 & \\
\hline TOTAL & 27 & 799,027 & & \\
\hline
\end{tabular}

Coeficiente de variação $=12,2 \%$

** $(\mathrm{P}<0,01)$

* $\quad(\mathrm{P}<0,05)$ 
Nas TABELAS 37,$38 ; 39,40 ; 41,42$; são apresentados os resultados de ganho de peso e suas análises de variân cia, respectivamente para o período total, período de crescimen to e período de acabamento. Os ganhos individuais por período, bem como os pesos individuais dos animais durante o ensaio, po dem ser vistos nas TABELAS $\mathrm{A}_{10}$ e $\mathrm{A}_{11}$.

Durante os períodos total e de crescimento, o tratamento 1 foi estatísticamente superior ao conjunto dos demais $(P<0,01)$, entretanto quando aquele tratamento foi compara do aos demais pelo teste de Duncan, não foram observados duran te os mencionados períodos, diferenças estatísticas entre os tratamentos $1,4,6$ e 7 indicando que a adição de 0,4 de 1 isina à ração com $100 \%$ de farelo de algodão, ou 0,2 e $0,4 \%$ de 1 isina à ração com $75 \%$ de farelo de algodão e $25 \%$ de farelo de soja, teve um efeito positivo sobre o ganho de peso. Considerando o tratamento 3 com adição de $0,2 \%$ de lisina, foi igualmente inferior ao tratamento testemunha, tanto no período de crescimento como no de acabamento em relação ao ganho de peso. No período de acabamento não houve diferença,e $\underline{\mathbf{s}}$ tatísticamente significativa, entre o tratamento 1 e o conjunto dos demais. Entretanto, pelo teste de Duncan houve diferença estatísticamente significativa entre o tratamento 2 e os de mais, mostrando que no período de acabamento a redução no ganho de peso persistiu quando a ração possuía, $100 \%$ de farelo de algodão.

0 estudo dos dados do conjunto dos tratamentos 2,3 e 4 comparado ao conjunto dos tratamentos 5, 6 e 7 mostra um maior ganho de peso, estatísticamente significativo $(\mathrm{P}<0,01)$, para o segundo conjunto de tratamentos. 0 presente resultado indicou que a alteração da fonte protéica, passando a $100 \%$ de fa relo de algodão para $75 \%$ de farelo de algodão mais $25 \%$ de fare 1o de soja, resultou em um efeito positivo sobre o ganho de pe so. Observando na TABELA 37, o resultado para ganho de peso no período total para o tratamento 1 , é possível notar que o mesmo foi superior ao tratamento 2 em $43,32 \%(P<0,05)$ e em relação 


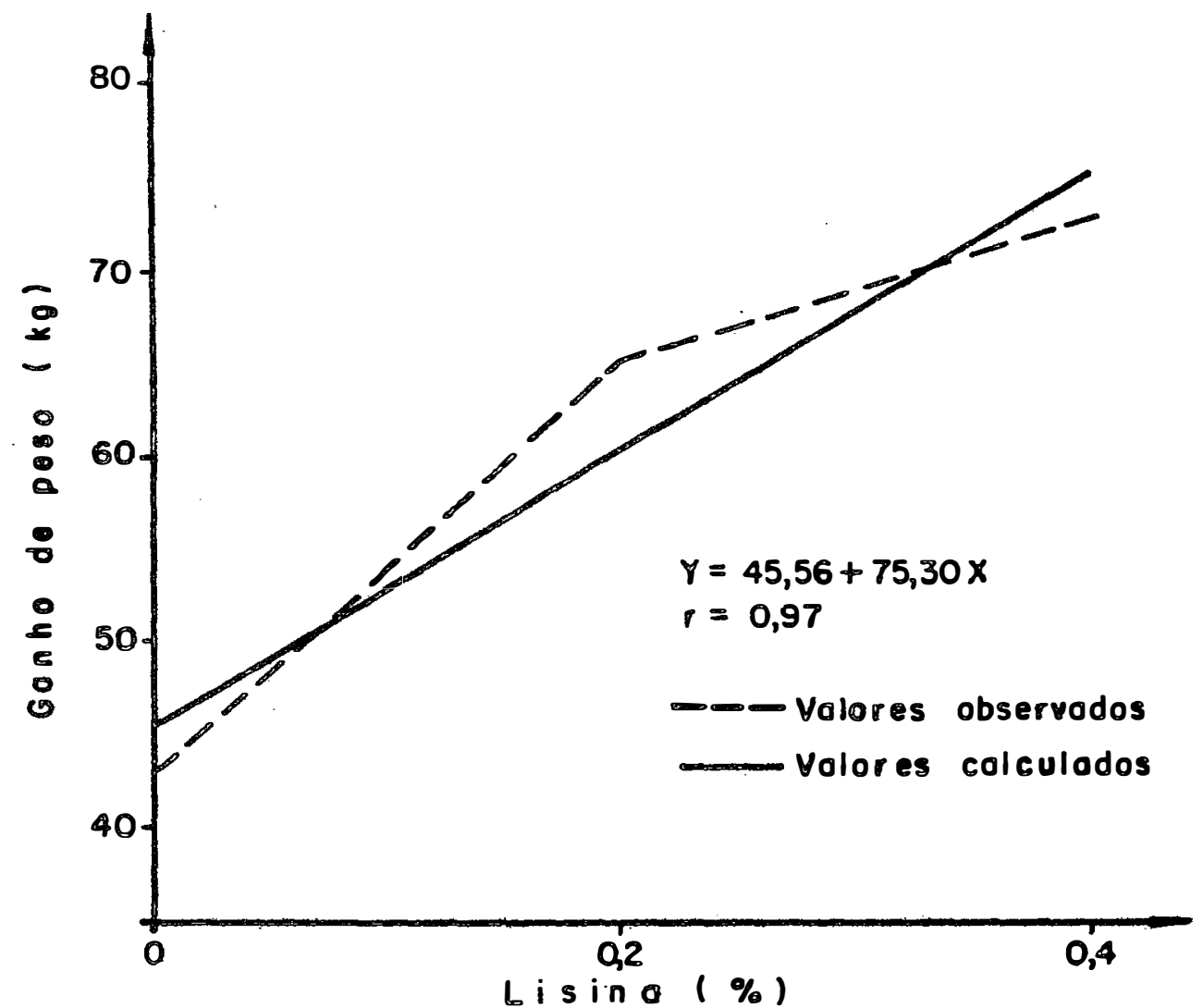

Figuro $9-$ Epieito dos protomenios (2,3 e 4) sobre o gonho de peso duronte o periodo pofol (94dios)

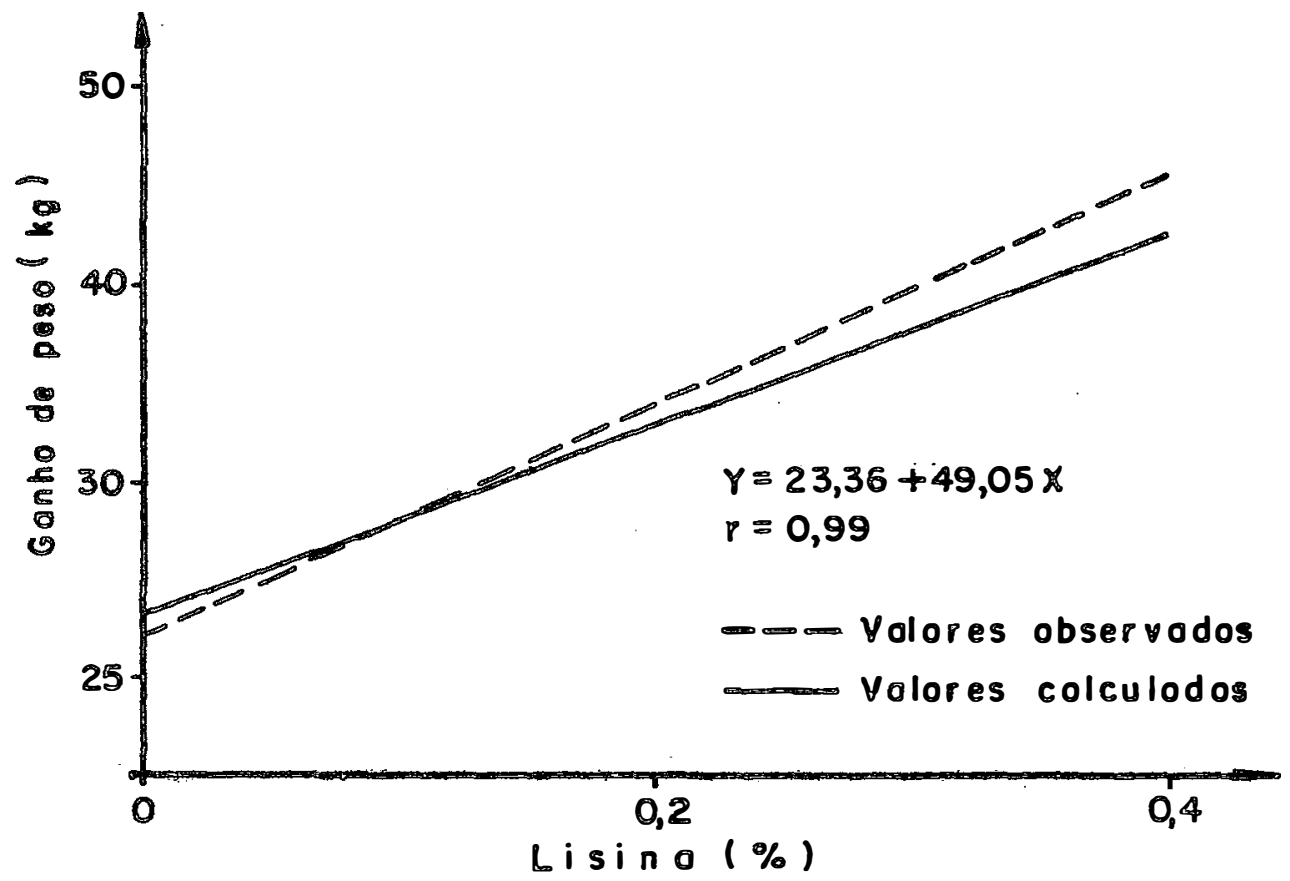

Figuro 10-Efeifo dos iroiomentos-(2,3e 4$)$ sobre o gonbo de peso duronie o fose de crescimento ( 56 dios) 
ao tratamento 5 foi apenas $15,35 \%$ melhor $(P<0,05)$, realçando a melhora dos ganhos de peso pelo fato de $25 \%$ do farelo de algodão haver sido substituído pelo farelo de soja, o que foi confirmado pelo teste de Duncan comparando o tratamento 2 com o tratamento 5 sendo a diferença entre os referidos tratamentos estatísticamente significativa $(P<0,05)$.

A adição de 0,2 e $0,4 \%$ de 1 isina respectivamente aos tratamentos 3 e 4 , que possuíam como fonte protéica exclu siva o farelo de algodão, melhorou os ganhos de forma linear $(\mathrm{P}<0,01)$ nos períodos estudados. Assim no período total, o tra tamento 2 sem adição de lisina, sofreu uma redução de 43,32\% no ganho de peso, enquanto a adição de 0,2 e $0,4 \%$ de 1 isina nos tratamentos 3 e 4 as reduções de ganho de peso foram respectivamente 17,40 e 7,10\% quando comparados ao tratamento 1 .

Do mesmo modo as reduções de ganho de peso dos tratamentos 2,3 e 4 no período de crescimento e períodode aca bamento foram respectivamente 49,$72 ; 23,05$ e $6,10 \%$ e 39,34;13,50 e $11,50 \%$ quando comparados ao tratamento 1 , mostrando o efeito positivo da adição de lisina, sendo que as médias de ganho de peso do tratamento 4 no período total, no de crescimento e no de acabamento não diferiram estatísticamente do testemunho (tra tamento 1), pelo teste de Duncan, o mesmo ocorrendo com o tratamento 3 , mas somente para o período de acabamento.

As equações de regressão foram: $Y=45,66+75,30 X$, $\mathrm{Y}=23,36+49,05 \mathrm{X}$ e $\mathrm{Y}=22,21+26,25 \mathrm{X}$ respectivamente para 0 período total, período de crescimento e período de acabamento, onde $Y$ representa o ganho de peso em $\mathrm{kg}$ no período e X a percentagem da adição de lisina. Os gräficos com os valores obse $\underline{r}$ vados e calculados podem ser vistos nas FIGURAS 9, 10 e 11, re pectivamente para o período total, período de crescimento e pe ríodo de acabamento.

As maiores reduções de ganho no período de cres cimento, parecem ser devidas ao fato dos animais, nesta fase, apresentarem uma exigência maior em lisina, e com o aumento da percentagem do farelo de algodão na ração ocorreu uma diminui- 


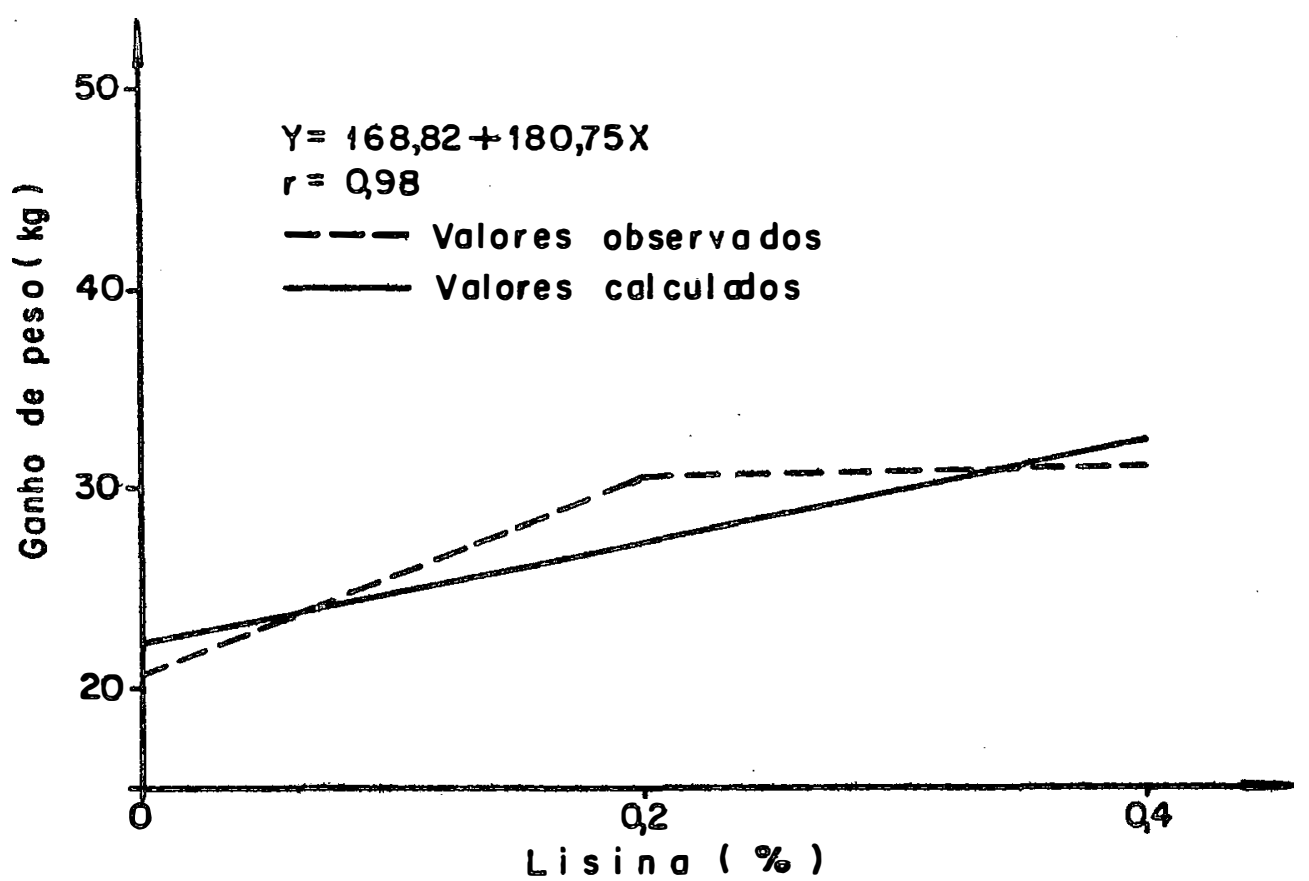

Figura 11- Efeiro dos tratomentos $(2,3 \mathrm{e} 4)$ sobre o ganho de peso durante o período de acobamento (35dias)

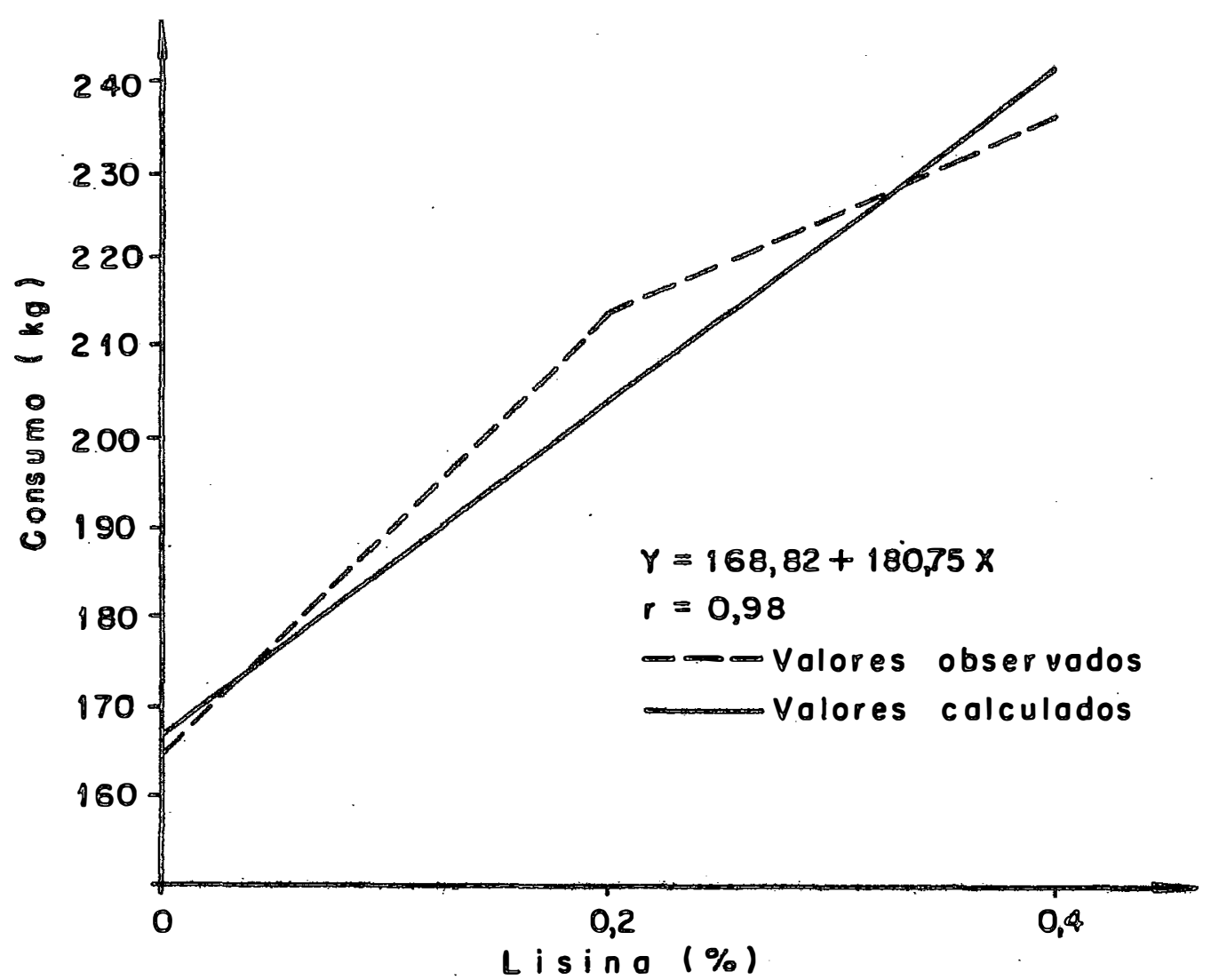

Figura 12 - Efeiso dos irotamentos $(2,3$ e 4$)$ sobre o consumo durante o periodo toial ( 91 dias) 
ção na percentagem daquele aminoãcido.

A importância da 1 isina no período de crescimen to é citada por NIELSEN et alii (1963), os quais suplementando com lisina uma ração composta por cevada e farelo de soja,obse $\underline{r}$ varam melhores respostas para o ganho de peso e conversão alimentar, durante aquele período.

No período total a adição de $0,2 \%$ de 1 isina ao tratamento 3 teve um efeito semelhante a substituição de $25 \%$ de farelo de algodão por farelo de soja. O ganho de peso no tratamento 3 foi de $17,40 \%$ menor e no tratamento 5 foi de $15,35 \%$ menor em relação ao tratamento 1. As mesmas comparações para o p ríodo de crescimento apresentaram respectivamente as percentagens de 23,05 e $18,89 \%$, sendo para o período de acabamento de 10,71 e $10,66 \%$. As diferenças entre os tratamentos 3 e 5 não foram estatisticamente significativas para o período total e de acabamento.

A adição de lisina à ração possuíndo $75 \%$ de fare 10 de algodão mais $25 \%$ de farelo de soja como fonte protéica,não apresentou efeito estatísticamente significativo, em dois períodos, sobre o ganho de peso. Entretanto esta adição no período total apesar de não significativo, mostrou tendência de melhorar os ganhos em $13,83 \%$ e $13,08 \%$, respectivamente para os trata mentos 6 e 7 , quando comparados ao tratamento 5 sem adição de lisina. As mesmas comparações para o período de crescimento apre sentaram as seguintes percentagens de aumento do ganho de peso, 18,15 e $16,44 \%$ e para o período de acabamento de 8,64 e 9,00\%. No periodo de crescimento o tratamento 5 diferiu significativamente dos tratamentos 6 e 7 .

0 menor efeito positivo da adição de lisina no período de acabamento, pode ser justificado pelo maior ajuste das rações as exigências normais dos animais neste período.

Os efeitos observados com a adição de lisina à rações tendo como fonte protéica exclusiva o farelo de algodão, estão dé acordo com os obtidos por CLAWSON et alii (1961), os. quais adicionaram $0,2 \%$ de lisina às rações para suínos e HALE e LYMAN (1970) que em dois ensaios trabalharam com níveis crescen 
tes de lisina à rações possuíndo o farelo de algodão como fonte protéica. Tanto os primeiros autores como os últimos conseguiram, um efeito positivo para o ganho de peso durante as fases de crescimento e acabamento.

Igualmente, MONCADA e MANER (1970) e WAHLSTROM e LIBAL (1974) obtiveram melhores ganhos de peso com adição de lisina, sendo que os primeiros autores trabalharam com rações tendo como fonte protéica o farelo de algodão mais o farelo de soja, e os últimos com rações contendo o farelo de soja como fonte exclusiva de proteína.

Resultados contrários foram obtidos por NOLAND (1968) que suplementou com lisina uma ração possuíndo o farelo de algodão como fonte protéica bem como por OROK et alii (1975) que também suplementaram com lisina uma ração tendo como fonte protéica uma mistura de $50 \%$ de farelo de soja e $50 \%$ de farelo de amendoim, sendo que em ambos os trabalhos os autores não en contraram qualquer efeito de suplementação com lisina sobre os ganhos de peso dos suínos em crescimento e acabamento.

\subsubsection{Consumo de ração}

As TABElAS 43,$44 ; 45,46 ; 47,48 ;$ mostram os re sultados obtidos para consumo de rações e suas análises de variância, respectivamente para o período total, período de cres cimento e período de acabamento.

Os consumos individuais por período, podem ser observados na TABELA A 12 .

Os resultados de consumo de ração no tratamento 1 não diferiram estatísticamente dos demais tratamentos conjun tamente. Entretanto quando foram analisados os dados de consumo de ração do conjunto dos tratamentos 2,3 e 4 comparados ao conjunto dos tratamentos 5, 6 e 7, foi observada uma diferença estatisticamente significativa $(P<0,05)$ tendo os animais do se gundo conjunto consumido mais ração em todos os períodos estudados. 
TABELA 43 - Consumo de Ração (kg) - Período Total (91 dias) - Ensaio II

\begin{tabular}{lcccccccc}
\hline \multirow{2}{*}{ BLOCOS } & \multicolumn{7}{c}{ TRATAMENTOS } & \multirow{2}{*}{ TOTAL } \\
\cline { 2 - 7 } & 1 & 2 & 3 & 4 & 5 & 6 & 7 & \\
\hline 1 & 213,7 & 167,3 & 236,3 & 208,5 & 195,6 & 212,9 & 218,2 & $1.452,5$ \\
2 & 237,8 & 167,3 & 208,8 & 276,9 & 256,1 & 267,0 & 244,3 & $1.658,2$ \\
3 & 235,5 & 173,3 & 238,1 & 266,2 & 234,6 & 254,1 & 228,9 & $1.630,7$ \\
4 & 233,1 & 149,9 & 171,6 & 195,4 & 147,7 & 249,2 & 232,8 & $1.406,7$ \\
\hline Total $^{*}$ & 920,1 & 657,8 & 854,8 & 947,0 & 861,0 & 983,2 & 924,2 & $6.148,1$ \\
Média $^{*}$ & $230,0^{\text {ab }}$ & $164,4^{\mathrm{C}}$ & $213,7^{\mathrm{b}}$ & $236,8^{\text {ab }}$ & $215,2^{\mathrm{b}}$ & $245,8^{\mathrm{a}}$ & $231,0^{\text {ab }}$ \\
\hline
\end{tabular}

* Letras diferentes diferem estatísticamente ao nível de 5\% pelo teste de Duncan

TABELA 44 - Anālise de Variância - Consumo de Ração - Período Total Ensaio II

\begin{tabular}{llrrc}
\hline Causa de variação & GL & \multicolumn{1}{c}{ SQ } & \multicolumn{1}{c}{ QM } & F \\
\hline$(1) \times(2,3,4,5,6,7)$ & 1 & 509,61 & 509,61 & 1,18 \\
$(2,3,4) \times,(5,6,7)$ & 1 & 3973,23 & 3973,23 & $9,17^{*}$ \\
Regressão Linear $(2,3,4)$ & 1 & 10454,58 & 10454,58 & $24,13^{* *}$ \\
Regressão Quadrätica $(2,3,4)$ & 1 & 457,63 & 457,63 & 1,06 \\
Regressão Linear $(5,6,7)$ & 1 & 499,28 & 499,28 & 1,15 \\
Regressão Quadrática $(5,6,7)$ & 1 & 1368,06 & 1368,06 & 3,16 \\
\hline Tratamentos & 6 & 17262,3850 & 2877,0642 & $6,64^{* *}$ \\
Blocos & 3 & 6798,2096 & 2266,0699 & $5,23^{*}$ \\
Resíduos & 18 & 7798,4379 & 433,2365 & \\
\hline TớrAL & 27 & 31859,0325 & & \\
\hline
\end{tabular}

Coeficiente de variação $=9,5^{\circ}$

** $(\mathrm{P}<0,01)$

* $(\mathrm{P}<0,05)$ 
TABELA 45 - Consumo de Ração (kg) - Período de Crescimento - (56 dias) Ensaio II

\begin{tabular}{lcrrrrrrr}
\hline \multirow{2}{*}{ BLOCOS } & \multicolumn{7}{c}{ TRATAMENTOS } & \multicolumn{1}{c}{ TOTAL } \\
\cline { 2 - 7 } & \multicolumn{1}{c}{1} & \multicolumn{1}{c}{3} & \multicolumn{1}{c}{4} & \multicolumn{1}{c}{5} & 6 & 7 & \\
\hline 1 & 107,1 & 75,7 & 120,2 & 118,8 & 90,4 & 118,8 & 109,0 & 740,0 \\
2 & 130,5 & 93,6 & 99,1 & 143,2 & 125,4 & 139,5 & 126,1 & 857,4 \\
3 & 116,9 & 98,8 & 125,4 & 138,7 & 113,5 & 134,4 & 114,8 & 842,5 \\
4 & 118,3 & 71,8 & 84,1 & 98,4 & 91,0 & 122,8 & 119,5 & 705,9 \\
\hline Total $^{2}$ & 472,8 & 339,9 & 428,8 & 499,1 & 420,3 & 515,5 & 469,4 & 3145,8 \\
Media $^{*}$ & $118,2^{\text {ab }}$ & $85,0^{\mathrm{c}}$ & $107,2^{\mathrm{b}}$ & $127,2^{\mathrm{a}}$ & $105,1^{\mathrm{b}}$ & $128,9^{\mathrm{a}}$ & $117,4^{\text {ab }}$ & \\
\hline
\end{tabular}

* Letras diferentes diferem estatísticamente ao nível de $5 \%$ pelo teste de Duncan

TABELA 46 - Análise de Variância - Consumo de Ração - Período de Crescimento Ensaio II

\begin{tabular}{lcrrc}
\hline Causa de variação & GL & \multicolumn{1}{c}{ SQ } & \multicolumn{1}{c}{ QM } & \multicolumn{1}{c}{$\mathrm{F}$} \\
\hline$(1) \times(2,3,4,5,6,7)$ & 1 & 159,71 & 159,71 & 1,36 \\
$(2,3,4) \times(5,6,7)$ & 1 & 786,60 & 786,60 & $6,72^{*}$ \\
Regressão Linear $(2,3,4)$ & 1 & 3168,08 & 3168,08 & $27,07^{*}$ \\
Regressão Quadrätica $(2,3,4)$ & 1 & 14,41 & 14,41 & 0,12 \\
Regressão Linear $(5,6,7)$ & 1 & 301,35 & 301,35 & 2,57 \\
Regressão Quadrätica $(5,6,7)$ & 1 & 831,90 & 831,90 & $7,11^{*}$ \\
\hline Tratamentos & 6 & 5262,07 & 877,01 & $7,49^{*}$ \\
Blocos & 3 & 2396,05 & 798,68 & $6,82^{*}$ \\
Resíduos & 18 & 2106,24 & 117,01 & \\
\hline TOTAL & 27 & 9764,37 & & \\
\hline
\end{tabular}

Coeficiente de variação $=9,6 \%$

** $(\mathrm{P}<0,01)$

* $(\mathrm{P}<0,05)$ 
TABELA 47 - Consumo de Ração (kg) - Período de Acabamento (35 dias) Ensaio II

\begin{tabular}{lccrcrrrr}
\hline \multirow{2}{*}{ BLOCOS } & \multicolumn{7}{c}{ TRATAMENTOS } & \multirow{2}{*}{ TOTAL } \\
\cline { 2 - 7 } & 1 & 2 & 3 & 4 & 5 & 6 & 7 & \\
\hline 1 & 106,6 & 91,6 & 116,1 & 89,7 & 105,2 & 94,1 & 109,2 & 712,5 \\
2 & 107,3 & 73,7 & 109,7 & 133,7 & 130,7 & 127,5 & 118,2 & 800,8 \\
3 & 118,6 & 74,5 & 112,7 & 127,5 & 121,1 & 119,7 & 114,1 & 788,2 \\
4 & 114,8 & 78,1 & 87,5 & 97,0 & 83,7 & 126,4 & 113,3 & 700,8 \\
\hline Tota1 & 447,3 & 317,9 & 426,0 & 447,9 & 440,7 & 467,7 & 454,8 & 3002,3 \\
Média & $111,8^{\text {a }}$ & $79,5^{\mathrm{b}}$ & $106,5^{\mathrm{a}}$ & $112,0^{\mathrm{a}}$ & $110,2^{\mathrm{a}}$ & $116,7^{\mathrm{a}}$ & $113,7^{\mathrm{a}}$ & \\
\hline
\end{tabular}

* Letras diferentes diferem estatísticamente ao nível de $5 \%$ pelo teste de Duncan

TABELA 48 - Análise de variância - Consumo de ração - Período de acabamentoEnsaio II

\begin{tabular}{lrrrc}
\hline Causa de variância & GL & SQ & \multicolumn{1}{c}{ QM } & \multicolumn{1}{c}{ F } \\
\hline$(1) \times(2,3,4,5,6,7)$ & 1 & 98,75 & 98,75 & 0,56 \\
$(2,3,4) \times(5,6,7)$ & 1 & 1224,07 & 1224,07 & $6,96^{*}$ \\
Regressão Linear $(2,3,4)$ & 1 & 2112,50 & 2112,50 & $12,01^{* *}$ \\
Regressão Quadrätica $(5,6,7)$ & 1 & 309,60 & 309,60 & 1,76 \\
Regressão Linear $(5,6,7)$ & 1 & 24,85 & 24,85 & 0,14 \\
Regressão Quadrática $(5,6,7)$ & 1 & 66,33 & 66,33 & 0,38 \\
\hline Tratamentos & 6 & 3836,115 & 639,35 & $3,36^{*}$ \\
Blocos & 3 & 1116,635 & 372,21 & 2,12 \\
Resíduos & 18 & 3165,582 & 175,87 & \\
\hline TOTAL & 27 & 8118,382 & & \\
\hline Coefici
\end{tabular}

Coeficiente de variação $=12,4 \%$

** $(\mathrm{P}<0,01)$

* $(\mathrm{P}<0,05)$ 


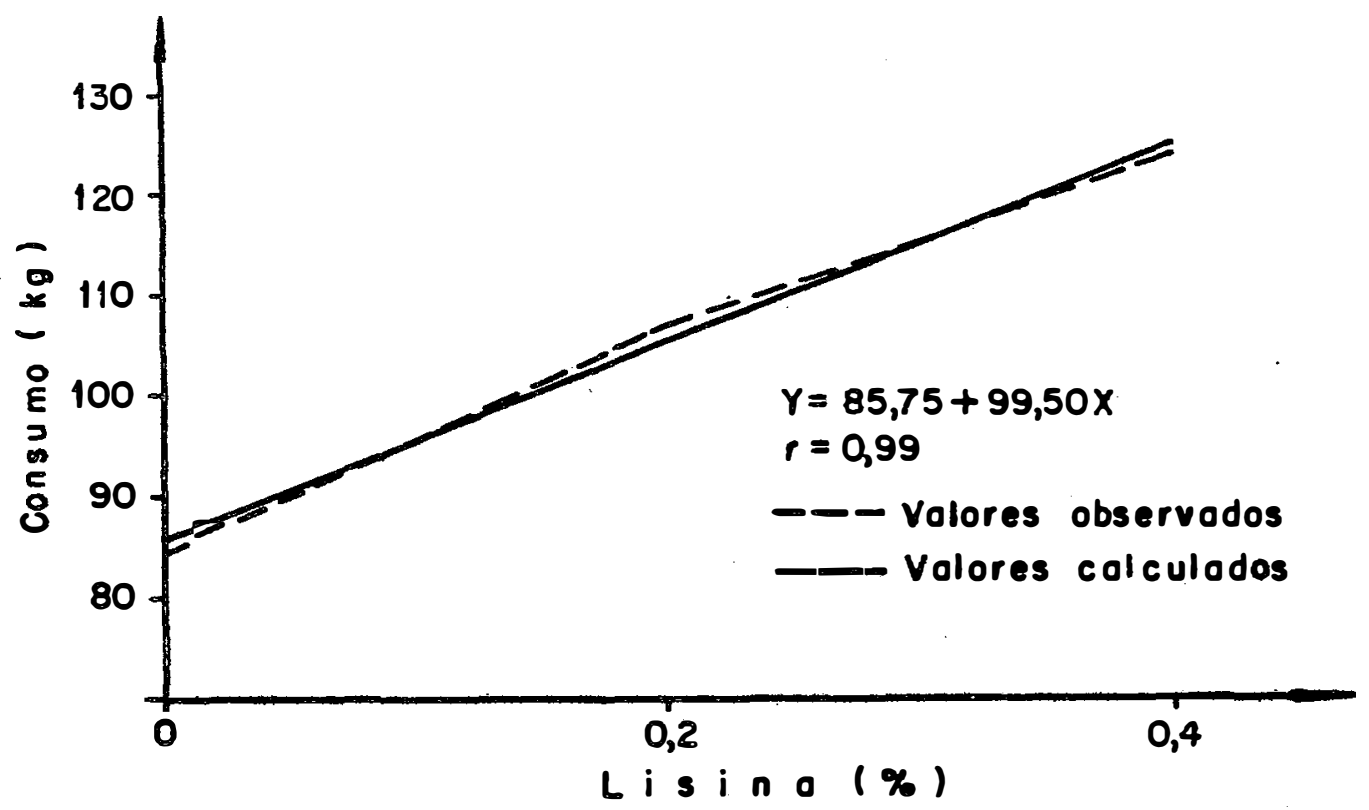

Figuro 13 - Efeito dos tratomentos $(2,3$ e 4 ) sobre o consumo duronte o fose de crescimento (56 dios)

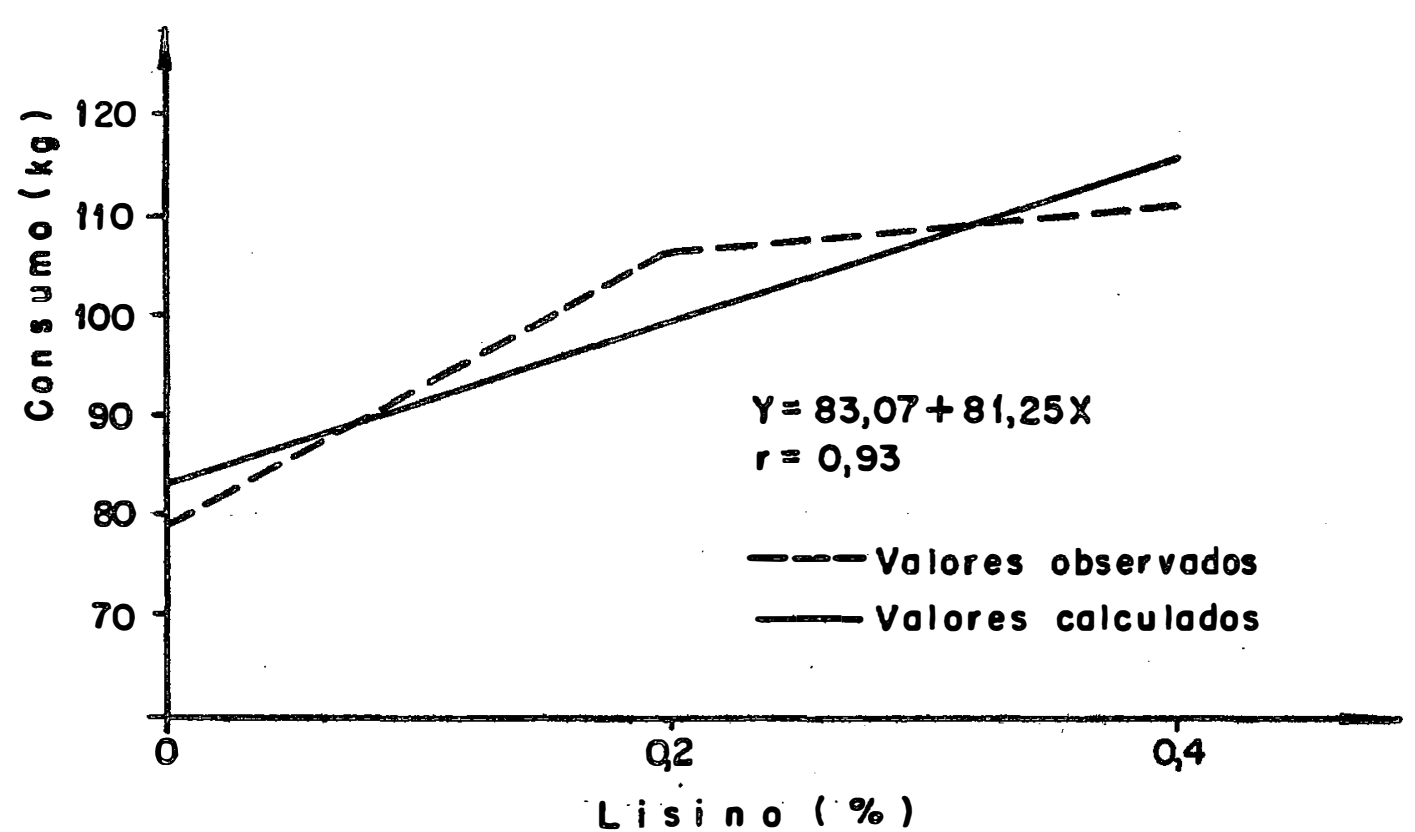

Figuro 14 - Efeito dos trotomentos $(2,3$ e 4$)$ sobre o consumo duronte o fose de ocobomento ( 35 dios) 
Estudando isoladamente o conjunto de tratamentos 2,3 e 4 foi observado que a adição de lisina teve efeito 1 inear positivo $(\mathrm{P}<0,01)$ nos três períodos estudados, sendo obti das as respectivas equações de regressão: $Y=168,82+180,75 X$, $Y=85,75+99,50 X$ e $Y=83,07+81,25 X$ onde $Y$ representa 0 consumo de ração em $\mathrm{kg}$ e $X$ a percentagem de lisina adicionada, as quais podem ser observadas as FIGURAS 12, 13 e 14 .

Resultados semelhantes aos do presente ensaio fó ram obtidos por HALE e LYMAN (1961), bem como WAHLSTROM et alii. (1971) e OROK et alii. (1975), cujos resultados mostraram um maior consumo de ração devido a adição de lisina à ração.

As equações mencionadas, bem como as curvas dos valores observados e calculados, podem ser vistas nas FIGURAS 12, 13 e 14, respectivamente, para o período total, período de crescimento e período de acabamento.

A adição de 0,2 e $0,4 \%$ de 1 isina à ração possuín do $100 \%$ de farelo de algodão como fonte protéica, aumentou o consumo de ração em 29,95 e 43,96\%; 26,15 e 46,83\%; 34,00 e $40,89 \%$ respectivamente para os períodos total, de crescimento e de acabamento, quando comparado com as rações sem adição de $\underline{s}$ se aminoácido. Foi observado no período total, que os consumos dos tratamentos 3 e 4, com adição de 0,2 e $0,4 \%$ de 1 isina respectivamente, foram estatísticamente diferentes do tratamento 2 pelo teste de Duncan, entretanto, quando comparados ao trata mento 1 , somente o tratamento 4 não diferiu significativamente, havendo o mesmo comportamento no período de crescimento, enquan to que no período de acabamento as médias dos tratamentos 3 e 4 não diferiram do tratamento 1 , mas sim do tratamento 2 como podemos observar na TABELA 47.

A adição de 0,2 e $0,4 \%$ de 1 isina nos tratamentos que possuíam como fonte protéica $75 \%$ de farelo de algodão mais 25\% de farelo de soja, teve um efeito positivo sobre o consumo para o período total e crescimento.

Em ambos períodos a adição de $0,2 \%$ de lisina (tratamento 6) aumentou significativamente $(P<0,05)$ o consumo 


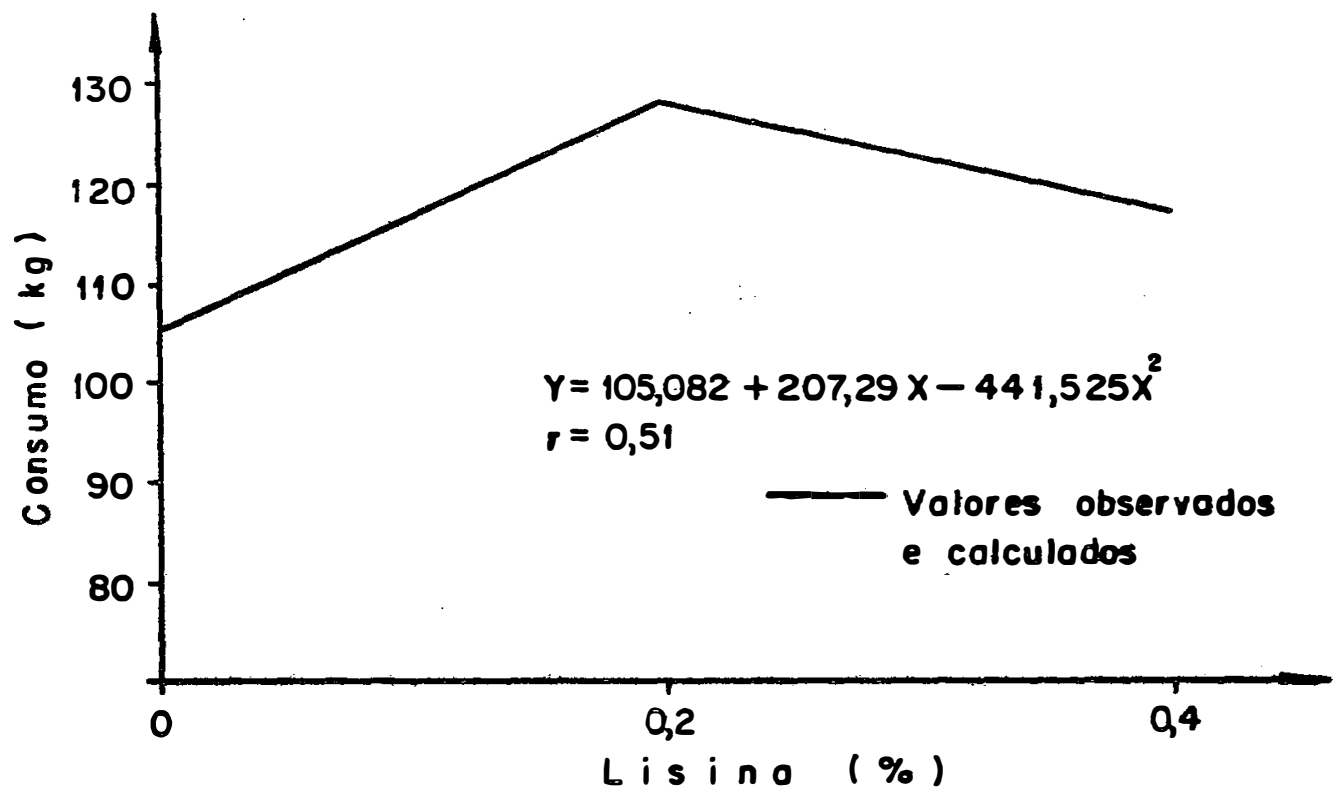

Figuro 15 - Efeito dos trotomentos $(5,6 \mathrm{e} 7)$ sobre o consumo durante-o fase de crescimento ( 56 dios).

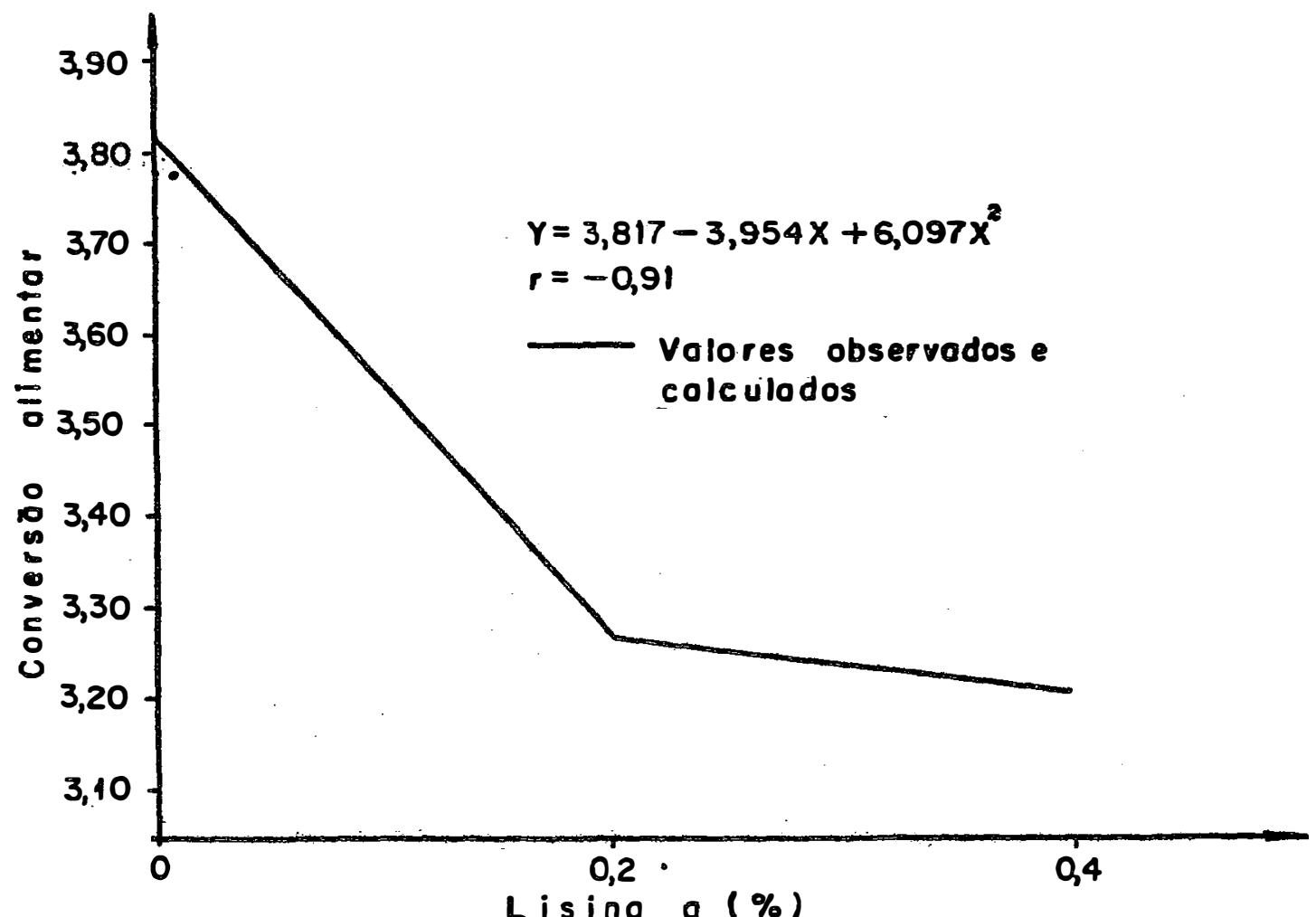

Figura 16 - Efeito dos iratomentos (2,3e 4 ) sobre a conversőo alimentar durante o período total ( 91 dias). 
quando comparado ao tratamento 5 sem adição de lisina. Já o tra tamento 7 para o qual a adição foi $0,4 \%$ de lisina o maior consu mo apresentado não diferiu significativamente do tratamento 5 apesar de também não diferir do tratamento 6 , como podemos observar nas TABELAS 43 e 45.

Nos períodos total e acabamento (TABELAS 41 e 42) nenhuma das regressões foram significativas, o que não ocorrem no período de crescimento onde houve um efeito quadrático $(P<0,05)$, (FIGURA 15).

SHARDA et alii (1975) observaram que ao fornecer uma ração com $0,9 \%$ de lisina o efeito sobre o consumo foi negativo, tendo os autores justificado o ocorrido indicando um provável desbalanceamento de aminoácido na ração, devido ao excesso de lisina, o que parece ter ocorrido com o tratamento 7 do presente ensaio.

\subsubsection{Conversão alimentar}

Nas TABELAS 49,$50 ; 51,52 ; 53,54 ;$ são apresenta dos os resultados obtidos para conversão alimentar e suas análi ses de variância, respectivamente para o período total, período de crescimento e período de acabamento.

As conversões alimentares individuais, por periodo, podem ser vistas na TABELA A 13 .

Nos três períodos, o tratamento 1 foi estatísticamente $(\mathrm{P}<0,01)$ superior ao conjunto dos demais tratamentos.

Analisando conjuntamente os dados de conversão alimentar obtidos nos tratamentos 2,3 e 4 e comparando ao conjunto dos tratamentos 5, 6 e 7 , foram observadas melhores conversões alimentares estatísticamente significativas $\quad(P<0,01)$ para os tratamentos do ûltimo conjunto, durante o período total e o período de crescimento, mas no período de acabamento 
TABELA 49 - Conversão Alimentar - Período Tota1 (91 dias) - Ensaio II

\begin{tabular}{lcccccccc}
\hline \multirow{2}{*}{ BLOCOS } & \multicolumn{9}{c}{ TRATAMENTOS } & \multirow{2}{*}{ TOTAL } \\
\cline { 2 - 8 } & 1 & 2 & 3 & 4 & 5 & 6 & 7 & \\
\hline 1 & 2,868 & 3,522 & 3,259 & 3,159 & 3,315 & 3,108 & 3,031 & 22,262 \\
2 & 2,918 & 4,235 & 3,288 & 3,440 & 3,162 & 3,256 & 3,035 & 23,334 \\
3 & 2,889 & 3,767 & 3,330 & 3,266 & 3,170 & 3,343 & 3,072 & 22,837 \\
4 & 2,969 & 3,747 & 3,207 & 2,983 & 3,265 & 3,195 & 3,083 & 22,449 \\
\hline Total & 11,644 & 15,271 & 13,084 & 12,848 & 12,912 & 12,902 & 12,221 & 90,882 \\
Media * $^{2,911^{\mathrm{a}}}$ & $3,818^{\mathrm{c}}$ & $3,271^{\mathrm{b}}$ & $3,212^{\mathrm{b}}$ & $3,228^{\mathrm{b}}$ & $3,225^{\mathrm{b}}$ & $3,055^{\mathrm{a}}$ & 3,246 \\
\hline
\end{tabular}

* Letras diferentes diferem estatísticamente ao nível de $5 \%$ pelo teste de Duncan

TABELA 50 - Análise de Variância - Conversão Alimentar - Período Total Ensaio II

\begin{tabular}{llccc}
\hline Causa de variação & GL & SQ & QM & F \\
\hline$(1) \times(2,3,4,5,6,7)$ & 1 & 0,5231 & 0,5231 & $27,24^{* *}$ \\
$(2,3,4) \times(5,6,7)$ & 1 & 0,4181 & 0,4181 & $21,78^{* *}$ \\
Regressão Linear $(2,3,4)$ & 1 & 0,7339 & 0,7339 & $38,23^{* *}$ \\
Regressão Quadrática $(2,3,4)$ & 1 & 0,1586 & 0,1586 & $8,26^{*}$ \\
Regressão Linear $(5,6,7)$ & 1 & 0,0597 & 0,0597 & 3,11 \\
Regressão Quadrática $(5,6,7)$ & 1 & 0,0187 & 0,0187 & 0,98 \\
\hline Tratamentos & 6 & 1,9121 & 0,3187 & $16,50^{* *}$ \\
Blocos & 3 & 0,0963 & 0,0321 & 1,67 \\
Resíduos & 18 & 0,3450 & 0,0192 & \\
\hline TOTAL & 27 & 2,3534 & & \\
\hline
\end{tabular}

Coeficiente de variação $=4,5^{\circ}$

** $(\mathrm{P}<0,01)$

* $(\mathrm{P}<0,05)$ 
TABELA 51 - Conversão Alimentar - Período de Crescimento (56 dias) Ensaio II

\begin{tabular}{lcccccccc}
\hline \multirow{2}{*}{ BLOCOS } & \multicolumn{7}{c}{ TRATAMENTOS } & \multicolumn{1}{c}{ TOTAL } \\
\cline { 2 - 8 } & 1 & 2 & 3 & 4 & 5 & 6 & 7 & \\
\hline 1 & 2,612 & 3,521 & 3,005 & 2,863 & 3,172 & 2,933 & 2,795 & 20,901 \\
2 & 2,691 & 4,255 & 3,249 & 3,182 & 2,787 & 3,066 & 2,712 & 21,942 \\
3 & 2,569 & 3,593 & 3,059 & 3,015 & 2,702 & 3,020 & 2,870 & 20,828 \\
4 & 2,629 & 3,682 & 3,130 & 2,696 & 2,984 & 2,924 & 2,685 & 20,730 \\
\hline Tota1 & 10,501 & 15,051 & 12,443 & 11,756 & 11,645 & 11,943 & 11,062 & 84,401 \\
Média * $^{2}$ & $2,625^{\mathrm{a}}$ & $3,763^{\mathrm{d}}$ & $3,111^{\mathrm{c}}$ & $2,939^{\mathrm{bc}}$ & $2,911^{\mathrm{bc}}$ & $2,986^{\mathrm{bc}}$ & $2,765^{\mathrm{ab}}$ & \\
\hline
\end{tabular}

* Letras diferentes diferem estatísticamente ao nível de 5\% pelo teste de Duncan

TABELA 52 - Anālise de Variância - Conversão Alimentar - Período de Crescimento - Ensaio II

\begin{tabular}{lcccc}
\hline Causa de variação & GL & SQ & QM & F \\
\hline$(1)$ x (2, 3, 4, 5, 6, 7) & 1 & 0,7064 & 0,7064 & $23,62^{* *}$ \\
$(2,3,4) \times(5,6,7)$ & 1 & 0,8817 & 0,8817 & $29,49 * *$ \\
Regressão Linear (2, 3, 4) & 1 & 1,3571 & 1,3571 & $45,39 * *$ \\
Regressão Quadrätica (2, 3, 4) 1 & 0,1538 & 0,1538 & $5,13^{*}$ \\
Regressão Linear (5, 6, 7) & 1 & 0,0425 & 0,0425 & 1,42 \\
Regressão Quadrätica (5, 6, 7) & 1 & 0,0579 & 0,0579 & 1,94 \\
\hline Tratamentos & 6 & 3,1994 & 0,5332 & $17,83^{* *}$ \\
Blocos & 3 & 0,1371 & 0,0457 & 1,53 \\
Resíduos & 18 & 0,5375 & 0,0299 & \\
TOTAL & 27 & 3,8740 & & \\
\hline
\end{tabular}

Coeficiente de variação $=5,7 \%$

** $(P<0,01)$

* $(\mathrm{P}<0,05)$ 
TABELA 53 - Conversão Alimentar - Período de Acabamento ( 35 dias) Ensaio II

\begin{tabular}{lcccccccc}
\hline \multirow{2}{*}{ BLOCOS } & \multicolumn{7}{c}{ TRATAMENTOS } & \multirow{2}{*}{ TOTAL } \\
\cline { 2 - 8 } & 1 & 2 & 3 & 4 & 5 & 6 & 7 & \\
\hline 1 & 3,182 & 3,523 & 3,572 & 3,661 & 3,449 & 3,361 & 3,309 & 24,057 \\
2 & 3,251 & 4,211 & 3,324 & 3,766 & 3,631 & 3,493 & 3,476 & 25,152 \\
3 & 3,294 & 4,027 & 3,695 & 3,591 & 3,784 & 3,800 & 3,307 & 25,498 \\
4 & 3,427 & 3,810 & 3,302 & 3,345 & 3,639 & 3,511 & 3,655 & 24,689 \\
\hline Total & 13,154 & 15,571 & 13,893 & 14,363 & 14,503 & 14,165 & 13,747 & 99,396 \\
Média* $^{*}$ & $3,288^{\mathrm{a}}$ & $3,893^{\mathrm{c}}$ & $3,473^{\mathrm{b}}$ & $3,591^{\mathrm{b}}$ & $3,626^{\mathrm{b}}$ & $3,541^{\mathrm{b}}$ & $3,437^{\text {ab }}$ \\
\hline
\end{tabular}

* Letras diferentes diferem estatísticamente ao nível de 5\% pelo teste de Duncan

TABELA 54 - Análise de Variância - Conversão Alimentar - Período de Acabamento - Ensaio II

\begin{tabular}{lcccc}
\hline Causa de variação & GL & SQ & QM & F \\
\hline$(1) \times(2,3,4,5,6,7)$ & 1 & 0,3187 & 0,3187 & $9,96^{* *}$ \\
$(2,3,4) \times(5,6,7)$ & 1 & 0,0830 & 0,0830 & 2,59 \\
Regressão Linear $(2,3,4)$ & 1 & 0,1824 & 0,1824 & $5,70^{*}$ \\
Regressão Quadrätica $(2,3,4)$ & 1 & 0,1922 & 0,1922 & $6,01^{*}$ \\
Regressão Linear $(5,6,7)$ & 1 & 0,0714 & 0,0714 & 2,23 \\
Regressão Quadrätica $(5,6,7)$ & 1 & 0,0003 & 0,0003 & 0,01 \\
\hline Tratanentos & 6 & 0,8482 & 0,1414 & $4,42^{*}$ \\
Blocos & 3 & 0,1665 & 0,0555 & 1,73 \\
Resíduos & 18 & 0,5764 & 0,0320 & \\
\hline TOTAL & 27 & 1,5911 & & \\
\hline
\end{tabular}

Coeficiente de variação $=5,0 \%$

** $(\mathrm{P}<0,01)$

* $\quad(\mathrm{P}<0,05)$ 


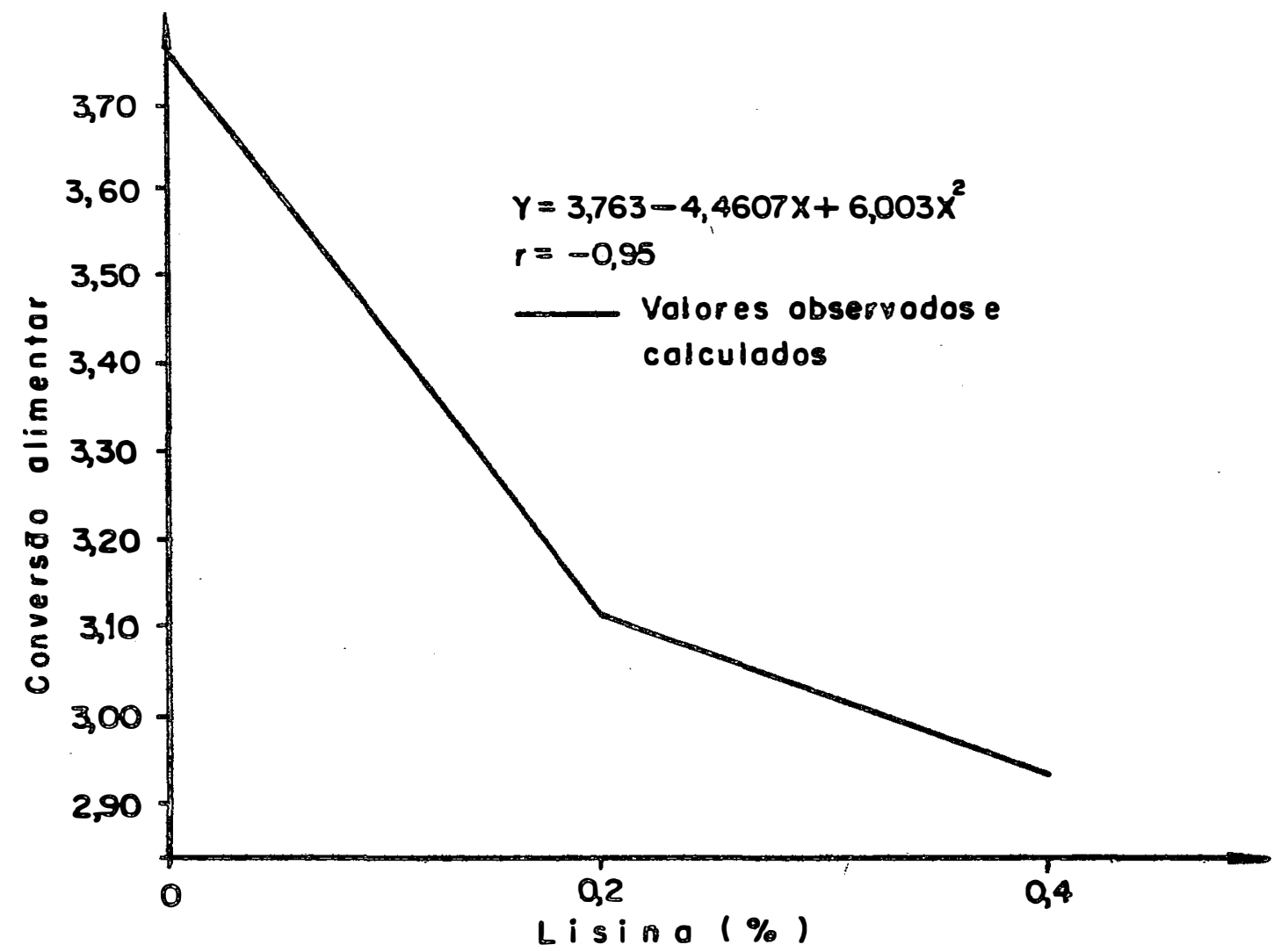

Figura 17 - Efeito dos trotomentos $(2,3$ - 4) sobre o conversōo - álimeripor durañé a pérído de crescimento(56dios)

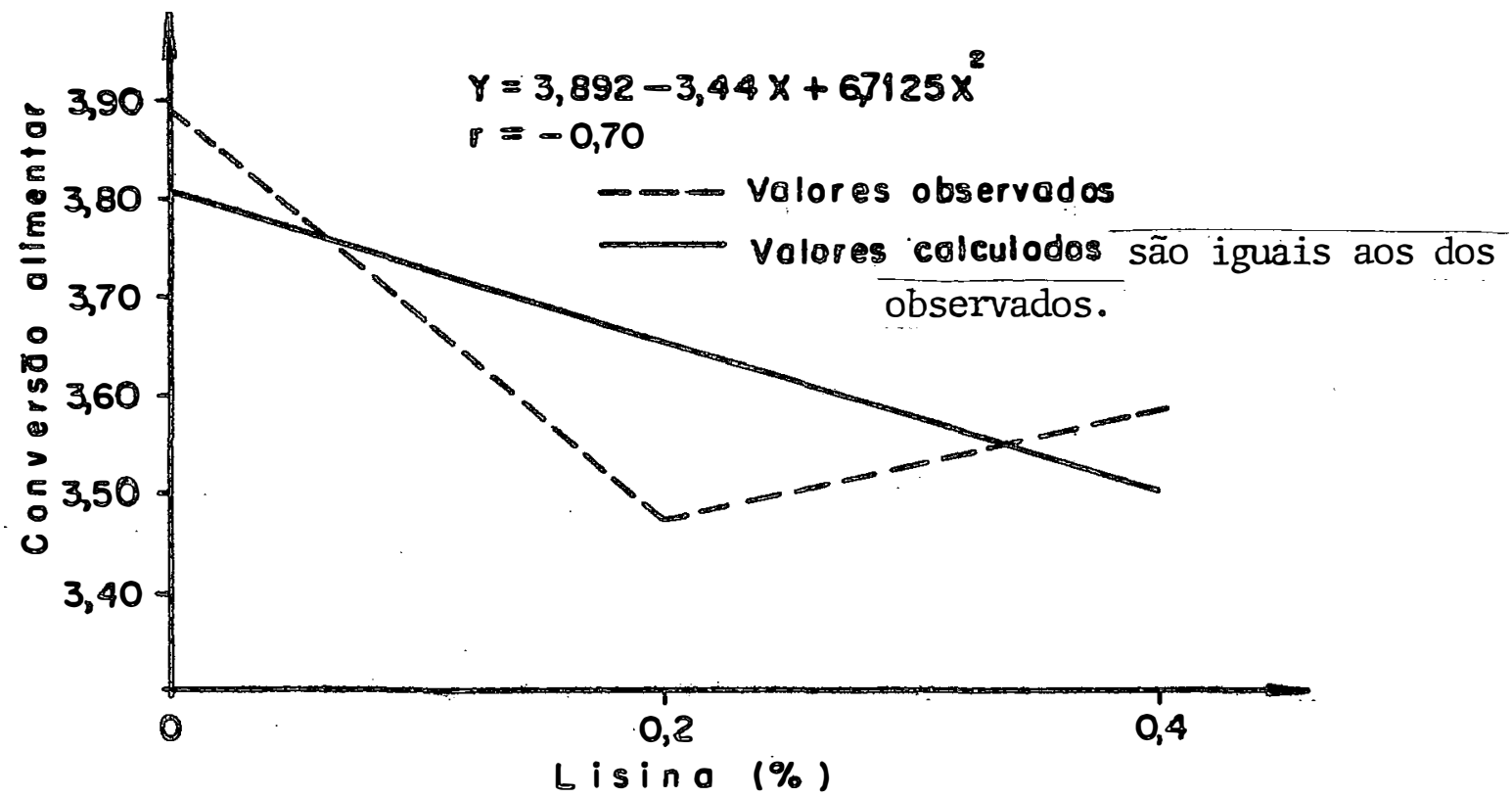

Figura 98 - Eq eî́o dos iratamentos (2,3 e 4) sobre a conversāo olimentor duranie o período de acabamento(35dias) 
não foram estatísticamente diferentes.

A análise dos dados dos tratamentos 2,3 e 4 indi cou uma melhora na conversão alimentar devida a adição de lisina. Para os três períodos os dados mostraram uma curva quadráti ca significativa $(P<0,05)$, sendo as equações as seguintes: $Y=3,817-3,954 X+6,097 X^{2}, Y=3,763-4,460 X+6,003 X^{2} \quad e$ $Y=3,892 X+6,7125 X^{2}$, respectivamente para o período total, pe ríodo de crescimento e período de acabamento. As equações de re gressão, bem como as curvas dos valores observados e calculados, podem ser vistos nas FIGURAS 16,17 e 18 .

As conversões alimentares dos tratamentos 2,3 e 4 foram respectivamente, 31,$16 ; 12,37$ e $10,34 \%$ no período total, 43,$35 ; 18,51$ e $11,96 \%$ no período de crescimento e 18,$40 ; 5,60$ e $9,20 \%$ no período de acabamento, piores do que a conversão do tratamento 1 , para os mesmos períodos. Foi observada melhor con versão alimentar nos tratamentos que receberam adição de lisina, sendo que pelo teste de Duncan os tratamentos 2,3 e 4 diferiram significativamente do tratamento $1(P<0,05)$. Comparando somente os tratamentos 2,3 e 4 , as TABELAS 49,51 e 53 mostram que os tratamentos 3 e 4 diferiram significativamente do tratamento 2 $(P<0,05)$, durante os três períodos, sendo que no período de cres cimento o tratamento 4 foi superior ao tratamento $3(P<0,05)$.

Resultados concordantes foram observados por MINER et alii. (1955), quando adicionaram $0,3 \%$ de lisina à uma ração para suínos em crescimento e acabamento, tendo o farelo de algodão como fonte protéica e obtiveram uma melhora significati va $(P<0,05)$ de $41,80^{\circ}$ em relação a testemunha sem adição de 1 isina.

Resultados semelhantes também foram obtidos por AGUIRRE et alii (1960), HALE e LYMAN (1961), bem como CLAWSON et alii (1961), sendo que os últimos autores conseguiram 32,38\% de melhora na conversão alimentar quando adicionaram $0,2 \%$ de $1 \underline{i}$ sina a uma ração contendo farelo de algodão degossipolizado, para suínos dos 14,5 aos $73,5 \mathrm{~kg}$ sendo o efeito estatísticamente significativo $(\mathrm{P}<0,01)$. 
HINTZ e HEITMAN (1967) adicionaram $0,2 \%$ de 1 is $\underline{i}$ na e conseguiram uma melhora da conversão alimentar de $8,47 \%$ em um primeiro ensaio e 7,70\% em um segundo, ambos com rações possuíndo o farelo de algodão como fonte protéica.

Outros autores que observaram efeito positivoda adição de lisina ao farelo de algodão sobre a conversão alimen tar foram NOLAND et alii. (1968) e KNABE et alii. (1975). Por ou tro lado MAIA (1969) não observou qualquer efeito positivo da adição de lisina.

Os resultados para conversão alimentar referentes a adição de 0,2 e $0,4 \%$ de 1 isina às rações possuíndo $75 \%$ de farelo de algodão mais $25 \%$ de farelo de soja como fonte protéica não apresentaram nenhuma regressão estatísticamente significativa, apesar de, no período total a adição de $0,4 \%$ do aminoácido (tratamento, 7) teve um efeito positivo sobre a conversão alimentar, diferindo estatísticamente do tratamento 5 sem lisina e do tratamento 6 com adição de $0,2 \%$ de 1 isina $(P<0,05)$. 0 tratamento 7 não diferiu estatísticamente do tratamento $1 \mathrm{em}$ ne nhum período estudado.

MAGRUDER et alii (1961) não observaram efeito da adição de lisina sobre a conversão alimentar de suínos submetidos a rações com níveis normais de proteína.

\subsubsection{Qualidade da carcaça}

Os resultados obtidos para rendimento de carcaça, espessura do toicinho, percentagem de pernil, área do olho de lombo e comprimento da carcaça, bem como suas análises de variância, podem ser vistos respectivamente nas TABELAS 55,$56 ; 57$, $58 ; 59,60 ; 61,62 ; 63,64$.

Os dados auxiliares para obtenção das características das carcaças estudadas podem ser vistos na TABELA $A_{4}$. os dados de rendimento de carcaça não apresenta- 
TABELA 55 - Rendimento de Carcaça $\left(\begin{array}{l}0 \\ 0\end{array}\right)$ - Ensaio II

\begin{tabular}{lrrrrrrrr}
\hline \multirow{2}{*}{ BLOCOS } & \multicolumn{7}{c}{ TRATAMENTOS } & \multicolumn{1}{c}{ TOTAL } \\
\cline { 2 - 7 } & \multicolumn{1}{c}{1} & \multicolumn{1}{c}{2} & \multicolumn{1}{c}{4} & \multicolumn{1}{c}{5} & \multicolumn{1}{c}{6} & \multicolumn{1}{c}{7} & \\
\hline 1 & 81,09 & 82,24 & 79,41 & 82,35 & 80,57 & 79,09 & 79,89 & 564,64 \\
2 & 80,80 & 80,94 & 93,31 & 80,82 & 82,95 & 81,30 & 79,39 & 569,51 \\
3 & 79,00 & 81,43 & 81,19 & 79,80 & 82,23 & 81,80 & 79,46 & 564,91 \\
4 & 78,09 & 81,58 & 79,12 & 79,88 & 74,93 & 81,27 & 81,87 & 556,74 \\
\hline Total & 318,98 & 326,19 & 323,03 & 322,85 & 320,68 & 323,46 & 320,61 & $2.255,80$ \\
Media & 79,74 & 81,55 & 80,76 & 80,71 & 80,17 & 80,86 & 80,15 & \\
\hline
\end{tabular}

TABELA 56 - Análise de Variância - Rendimento de Carcaça $\left(\begin{array}{l}\% \\ 0\end{array}\right)$ - Ensaio II

\begin{tabular}{lcccc}
\hline Causa de variação & GL & SQ & QM & F \\
\hline$(1) \times(2,3,4,5,6,7)$ & 1 & 3,14 & 3,14 & 0,97 \\
$(2,3,4) \times(5,6,7)$ & 1 & 2,23 & 2,23 & 0,69 \\
Regressão Linear $(2,3,4)$ & 1 & 1,39 & 1,39 & 1,39 \\
Regressão Quadrätica $(2,3,4)$ & 1 & 0,37 & 0,37 & 0,11 \\
Regressão Linear $(5,6,7)$ & 1 & 0,00 & 0,00 & 0,00 \\
Regressão Quadrätica $(5,6,7)$ & 1 & 1,32 & 1,32 & 0,41 \\
\hline Tratamentos & 6 & 8,45 & 1,41 & 0,43 \\
Blocos & 3 & 12,05 & 4,02 & 1,24 \\
Resíduos & 18 & 58,50 & 3,25 & \\
\hline TOTAL & 27 & 79,00 & & \\
\hline Coefici
\end{tabular}

Coeficiente de variação $=2,2 \%$ 
TABELA 57 - Espessura do Toicinho - (cm) - Ensaio II

\begin{tabular}{lrrrrrrrr}
\hline \multirow{2}{*}{ BLOCOS } & \multicolumn{7}{c}{ TRATAMENTOS } & \multicolumn{1}{c}{ TOTAL } \\
\cline { 2 - 7 } & \multicolumn{1}{c}{1} & \multicolumn{1}{c}{2} & \multicolumn{1}{c}{3} & \multicolumn{1}{c}{4} & \multicolumn{1}{c}{5} & 6 & 7 & \\
\hline 1 & 3,80 & 4,80 & 4,23 & 3,83 & 3,90 & 3,83 & 3,83 & 28,22 \\
2 & 4,87 & 3,03 & 3,90 & 4,50 & 4,73 & 4,13 & 3,87 & 29,02 \\
3 & 4,13 & 3,83 & 4,07 & 4,50 & 4,83 & 4,30 & 3,63 & 29,29 \\
4 & 3,77 & 3,90 & 3,20 & 3,13 & 3,00 & 4,07 & 4,10 & 25,17 \\
\hline Total & 16,57 & 15,56 & 15,40 & 15,96 & 16,46 & 16,33 & 15,43 & 111,71 \\
Média & 4,14 & 3,89 & 3,85 & 3,99 & 4,11 & 4,08 & 3,86 & \\
\hline
\end{tabular}

TABELA 58 - Análise de Variância - Espessura do Toicinho - Ensaio II

\begin{tabular}{lcccc}
\hline Causa de Variação & GL & SQ & QM & F \\
\hline$(1)$ x (2, 3, 4, 5, 6, 7) & 1 & 0,11 & 0,11 & 0,39 \\
$(2,3,4)$ x (5, 6, 7) & 1 & 0,07 & 0,07 & 0,25 \\
Regressão Linear (2, 3,4) & 1 & 0,02 & 0,02 & 0,07 \\
Regressão Quadrätica (2, 3,4) & 1 & 0,02 & 0,02 & 0,08 \\
Regressão Linear (5, 6, 7) & 1 & 0,13 & 0,13 & 0,47 \\
Regressão Quadrätica (5, 6, 7) & 1 & 0,03 & 0,03 & 0,09 \\
\hline Tratamentos & 6 & 0,38 & 0,06 & 0,22 \\
Blocos & 3 & 1,54 & 0,51 & 1,81 \\
Resíduos & 18 & 5,12 & 0,28 & \\
\hline TOTAL & 27 & 7,04 & & \\
\hline
\end{tabular}

Coeficiente de Variação $=13,4 \%$ 
TABELA 59 - Percentagem de Pernil - Ensaio II

\begin{tabular}{lcccccccc}
\hline \multirow{2}{*}{ BLOCOS } & \multicolumn{7}{c}{ TRATAMENTOS } & \multicolumn{1}{c}{ TOTAL } \\
\cline { 2 - 7 } & 1 & 2 & 3 & 4 & 5 & 6 & 7 & \\
\hline 1 & 15,95 & 14,09 & 14,60 & 14,28 & 13,98 & 15,37 & 14,61 & 102,88 \\
2 & 14,85 & 14,10 & 13,86 & 14,16 & 13,78 & 14,64 & 14,52 & 99,91 \\
3 & 15,06 & 13,60 & 13,29 & 14,68 & 14,05 & 14,17 & 15,18 & 100,03 \\
4 & 15,18 & 13,57 & 15,74 & 15,67 & 14,95 & 14,58 & 13,42 & 103,11 \\
\hline Total $^{2}$ & 61,04 & 55,36 & 57,49 & 58,79 & 56,76 & 58,76 & 57,73 & 405,93 \\
Media* $^{*}$ & $15,26^{\text {a }}$ & $13,84^{\mathrm{b}}$ & $14,37^{\text {ab }}$ & $14,69^{\text {ab }}$ & $14,19^{\text {ab }}$ & $14,69^{\text {ab }}$ & $14,43^{\text {ab }}$ & \\
\hline
\end{tabular}

* Letras diferentes diferem estatísticamente ao nível de $5 \%$ pelo teste de Duncan

TABELA 60 - Análise de Variância - Percentagem de Pernil - Ensaio II

\begin{tabular}{lcccc}
\hline Causa de Variação & GL & SQ & QM & F \\
\hline$(1) \times(2,3,4,5,6,7)$ & 1 & 2,71 & 2,71 & $6,45^{*}$ \\
$(2,3,4) \times(5,6,7)$ & 1 & 0,11 & 0,11 & 0,26 \\
Regressão Linear $(2,3,4)$ & 1 & 1,47 & 1,47 & 3,50 \\
Regressão Quadrätica $(2,3,4)$ & 1 & 0,03 & 0,03 & 0,05 \\
Regressão Linear $(5,6,7)$ & 1 & 0,12 & 0,12 & 0,26 \\
Regressão Quadrática $(5,6,7)$ & 1 & 0,38 & 0,38 & 0,84 \\
\hline Tratamentos & 6 & 4,82 & 0,12 & $2,81^{*}$ \\
Blocos & 3 & 1,31 & 0,44 & 1,05 \\
Resíduos & 18 & 7,59 & 0,42 & \\
\hline TOTAL & 27 & 326,61 & & \\
\hline
\end{tabular}

Coeficiente de Variação $=13,4 \%$

* * $(\mathrm{P}<0,01)$

* $(\mathrm{P}<0,05)$ 
ram diferenças estatísticamente significativas, sendo os resultados bem uniformes para todos os tratamentos. Resultados contrários foram encontrados por MAGRUDER et alii. (1961) que obse $\underline{r}$ varam um aumento no rendimento de carcaça com a adição de $0,1 \%$ de 1 isina, enquanto JURGENS et alii obtiveram um pior rendimento de carcaça com adição de $0,1 \%$ de 1 isina na ração.

Os resultados de rendimento de carcaça do presente ensaio são concordantes com os obtidos por MEADE et alii. (1966a), MEADE et alii (1966b) bem como BROWN et alii. que, ao suplementarem rações de acabamento com lisina em níveis crescentes, não observaram nenhum efeito sobre o rendimento de carcaça dos suínos.

Os resultados para espessura do toicinho não mostraram diferenças significativas para qualquer desdobramento das somas dos quadrados como pode ser observado na TABELA 58 estando de acordo com as observações de SEWELL e PRICE (1962), REIMER et alii (1964), MEADE et alii (1966a), MEADE et alii (1966b), HINTZ e HEITMAN (1967), BELL e VOLDING (1968), BROWN et alii. (1973) e WAHLSTROM e LIBAL (1974).

A TABELA 59 mostra os resultados para a percentagem do pernil, sendo que somente quando o tratamento 1 foi comparado com o conjunto dos demais tratamentos houve diferença es tatísticamente significativa $(P<0,05)$.

A adição de lisina às rações possuíndo $100 \%$ de fa relo de algodão como fonte protéica não teve efeito sobre a per centagem do pernil. Igualmente não houve qualquer efeito devido a adição de lisina às rações possuíndo $75 \%$ de farelo de algodão mais $25 \%$ de farelo de soja como fonte protéica.

Somente o tratamento 2 diferiu estatísticamente do tratamento 1 , quando foram comparadas as médias desses tratamen tos.

Os presentes resultados obtidos para a percentagem do pernil concordam com diversos autores como SEWELL e PRICE (1962), REIMER et alii (1964), MEADE et alii (1966a) e MEADE et alii (1966b). Do mesmo modo nenhuma diferença foi observada por 
TABELA 61 - Área do 01ho de Lombo $\left(\mathrm{cm}^{2}\right)$ - Ensaio II

\begin{tabular}{lcccccccc}
\hline \multirow{2}{*}{ BLOCOS } & \multicolumn{7}{c}{ TRATAMENTOS } & \multirow{2}{*}{ TOTAL } \\
\cline { 2 - 8 } & 1 & 2 & 3 & 4 & 5 & 6 & 7 & \\
\hline 1 & 31,0 & 25,6 & 20,1 & 22,0 & 25,2 & 28,5 & 26,6 & 188,0 \\
2 & 35,3 & 20,6 & 32,9 & 30,4 & 28,2 & 30,6 & 32,0 & 210,0 \\
3 & 31,4 & 22,2 & 31,3 & 38,2 & 26,3 & 28,4 & 29,9 & 197,7 \\
4 & 30,3 & 20,8 & 23,5 & 26,8 & 21,1 & 32,3 & 29,9 & 184,7 \\
\hline Tota1 $^{2}$ & 128,0 & 89,2 & 116,8 & 107,4 & 100,8 & 119,8 & 118,4 & 780,4 \\
Media & $32,0^{\text {a }}$ & $22,3^{\text {d }}$ & 29,2 & $26,85^{\text {bc }}$ & $25,2^{\text {cd }}$ & $29,9^{\text {ab }}$ & $29,6^{\text {ab }}$ \\
\hline
\end{tabular}

* Letras diferentes diferem estatísticamente ao nível de $5 \%$ pelo teste de Duncan

TABELA 62 - Anālise de Variância - Area do Olho de Lombo - Ensaio II

\begin{tabular}{lcccc}
\hline Causa de Variação & GL & SQ & QM & F \\
\hline$(1) \times(2,3,4,5,6,7)$ & 1 & 79,55 & 79,55 & $12,26^{* *}$ \\
$(2,3,4) \times(5,6,7)$ & 1 & 27,30 & 27,30 & $4,21^{*}$ \\
Regressão Linear (2, 3, 4) & 1 & 41,41 & 41,41 & $6,38^{*}$ \\
Regressão Quadrätica $(2,3,4)$ & 1 & 57,04 & 57,04 & $8,79^{* *}$ \\
Regressão Linear $(5,6,7)$ & 1 & 38,72 & 38,72 & $5,97^{*}$ \\
Regressão Quadrätica $(5,6,7)$ & 1 & 17,34 & 17,34 & 2,67 \\
\hline Tratamentos & 6 & 261,35714 & 43,55952 & $6,71^{* *}$ \\
Blocos & 3 & 55,33428 & 18,44476 & 2,84 \\
Resíduos & 18 & 116,80512 & 6,48921 & \\
\hline TƠTAL & 27 & 433,49714 \\
\hline
\end{tabular}

Coeficiente de Variação $=9,2 \%$

** $(\mathrm{P}<0,01)$

$*(\mathrm{P}<0,05)$ 
TABELA 63 - Comprimento da Carcaça (cm) - Ensaio II

\begin{tabular}{lcccccccc}
\hline \multirow{2}{*}{ BLOCOS } & \multicolumn{7}{c}{ TRATAMENTOS } & \multirow{2}{*}{ TOTAL } \\
\cline { 2 - 7 } & 1 & 2 & 3 & 4 & 5 & 6 & 7 & \\
\hline 1 & 99,0 & 97,5 & 95,5 & 90,3 & 93,5 & 93,3 & 92,3 & 661,40 \\
2 & 94,2 & 90,0 & 95,0 & 93,5 & 101,0 & 97,5 & 95,2 & 666,40 \\
3 & 96,5 & 98,5 & 101,5 & 98,0 & 95,5 & 95,5 & 94,5 & 680,00 \\
4 & 95,7 & 93,5 & 90,5 & 90,5 & 93,0 & 88,5 & 88,0 & 639,70 \\
\hline Tota1 & 385,4 & 379,5 & 382,5 & 372,3 & 383,0 & 374,8 & 370,0 & 2647,50 \\
Media & 96,35 & 94,87 & 95,62 & 93,07 & 93,75 & 93,70 & $92,50$. \\
\hline
\end{tabular}

TABELA 64 - Anälise de Variância - Comprimento da Carcaça - Ensaio II

\begin{tabular}{lcrrc}
\hline Causa de Variação & GL & SQ & QM & F \\
\hline (1) x $(2,3,4,5,6,7)$ & 1 & 15,06 & 15,06 & 1,75 \\
$(2,3,4) \times(5,6,7)$ & 1 & 1,76 & 1,76 & $0,20$. \\
Regressão Linear $(2,3,4)$ & 1 & 6,48 & 6,48 & 0,75 \\
Regressão Quadrätica $(5,6,7)$ & 1 & 7,26 & 7,26 & 0,84 \\
Regressão Linear $(5,6,7)$ & 1 & 21,12 & 21,12 & 2,46 \\
Regressão Quadrática $(5,6,7)$ & 1 & 0,48 & $0,48$. & 0,48 \\
\hline Tratamentos & 6 & 52,17 & 8,69 & 1,01 \\
Blocos & 3 & 120,13 & 40,04 & $4,67 *$ \\
Resíduos & 18 & 154,31 & 8,57 & \\
\hline TOTAL & 27 & 326,61 & & \\
\hline
\end{tabular}

Coeficiente de Variação $=4,5 \%$

$*(\mathrm{P}<0,05)$ 
SEERLEY et alii. (1973) com a adição de $0,1 \%$ de 1 isina.

No entanto os resultados do presente ensaio discordam daqueles apresentados por JURGENS et alii (1967) que adicionaram $0,1 \%$ de lisina a ração e obtiveram efeito positivo, estatísticamente significativo $(P<0,05)$, sobre a percentagem do pernil.

Ainda considerando a percentagem de pernil, houve um decréscimo, de 9,$30 ; 5,80$ e 3,69\% respectivamente para os tratamentos 2,3 e 4 em relação ao tratamento 1 , sendo que somente o tratamento 2 diferiu significativamente do tratamento 1 pelo teste de Duncan. A mesma comparação para os tratamentos 5,6 e 7 mostraram respectivamente um decréscimo de 7,01; 3,73 e $5,40 \%$.

Os resultadọs para área do olho de lombo são mostrados na TABELA 61 sendo que foi observada na TABELA 62 uma diferença es tatísticamente significativa entre o tratamento 1 e o conjunto dos demais tratamentos.

A área do olho de lombo foi no tratamento 2, 30,31\% menor em relação do tratamento $1(P<0,05)$, sendo que a adição de lisina nos tratamentos que possuíam $100 \%$ de farelo de algodão mostrou um efeito quadrático significativo $(\mathrm{P}<0,01)$ e a equação de regressão foi $Y=22,3002+57,626 \mathrm{X}-115,6275 \mathrm{X}^{2}$, on de $Y$ representa a área do olho de lombo em $\mathrm{cm}^{2}$ e $X$ a percentagem de adição de lisina a ração. A FIGURA 19 mostra que para o nível de $0,2 \%$ de lisina, houve, relativamente, um grande aumen to na área do olho de lombo em relação ao tratamento 2 (semadi ção de 1 isina), e que com a adição de $0,4 \%$ o efeito foi menos evidente, embora ainda fosse positivo, sendo que os tratamentos 3 e 4 diferiram significativamente $(P<0,05)$ do tratamento 2 mas não entre si.

Efeito igualmente positivo, linear e significati vo $(\mathrm{P}<0,05)$ foi observado entre os tratamentos 5,6 e 7 , sendo que os tratamentos 6 e 7 foram superiores significativamente $(P<0,05)$ ao tratamento 5 , mas não entre si. 


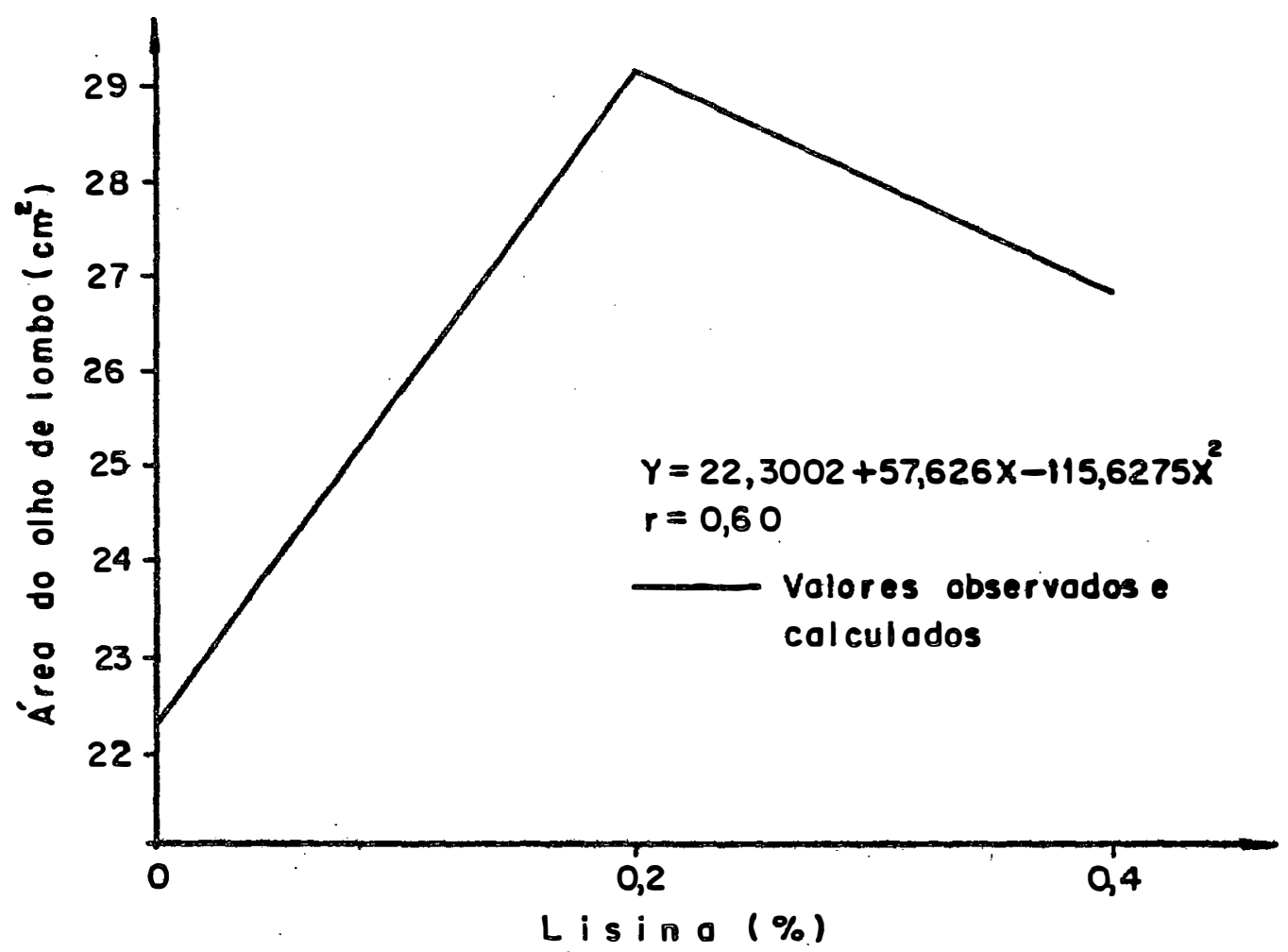

Figuro 19 - Efeito dos irotamentos (2,3e 4) sobre o óreo do olno de $10 \mathrm{mbo}$

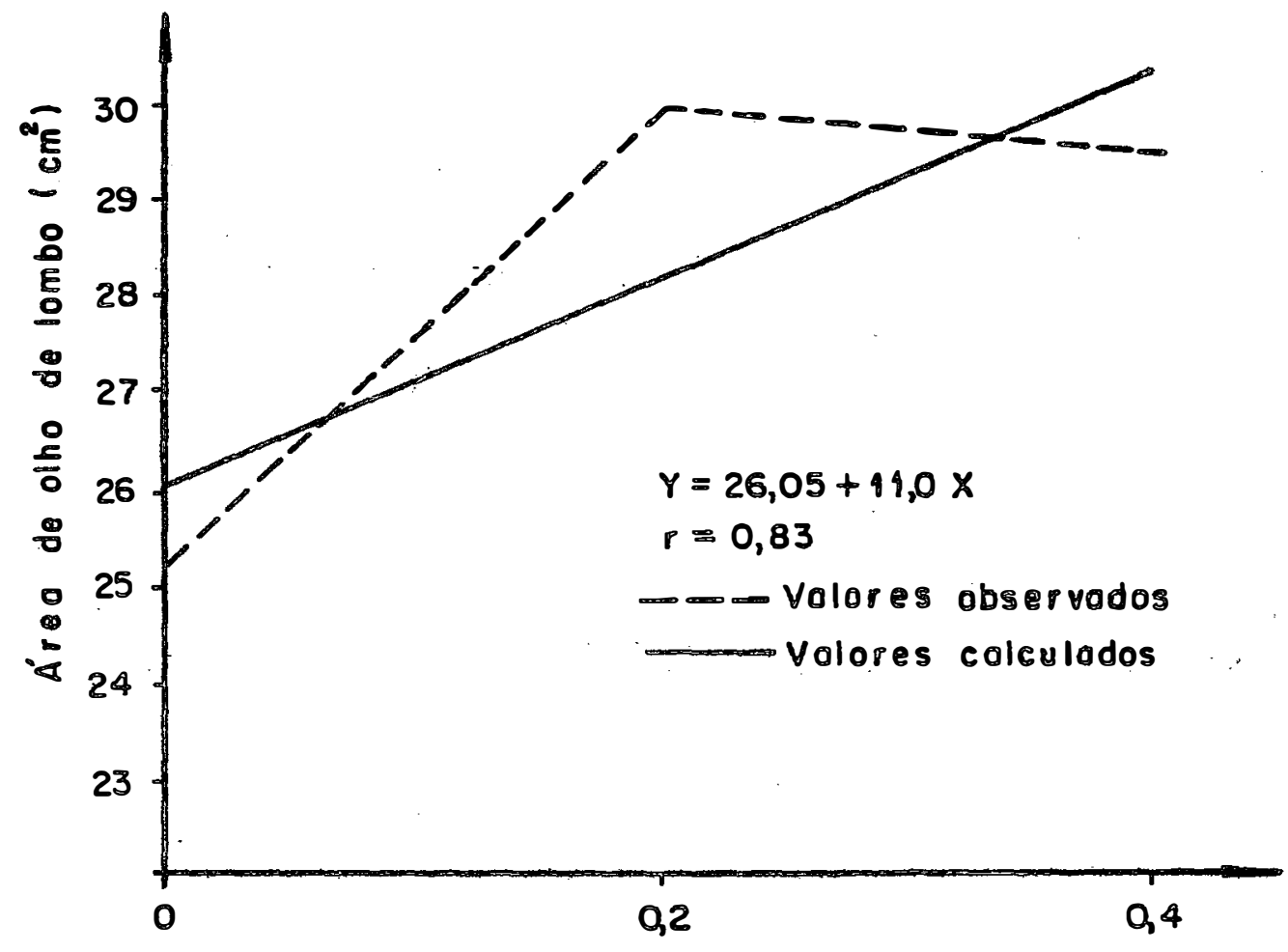

Lisino (\%)

Figura 20-Efeipo dos propomentos $(5,6 \mathrm{e})$ sobre o áreo do olho de lombo. 
Apesar do melhor balanceamento de aminoácidos nos tratamentos 5, 6 e 7 foi observado um efeito positivo da adição de lisina sobre a ärea do olho de lombo, sendo o tratamento 5 estatisticamente diferente dos tratamentos 6 e $7(P<0,05)$. Na FIGURA 20 observamos o efeito dos tratamentos 5,6 e 7 sobre a área do olho de lombo.

O presente resultado está de acordo com BROWN et alii (1973) que em seu estudo concluíram que a ärea do olho de lombo é a característica da carcaça mais sensível a uma inadequada quantidade de lisina na ração ou seja, a exigência em lisina para a máxima área do olho de lombo é maior que para as de mais características.

Concordando com o presente trabalho RODRIGUES et alii (1969) observaram um aumento de 18,58\% na área do olho de lombo devido a adição daquele aminoácido.

Do mesmo modo JURGENS et alii. (1967), BROWN et alii (1973), SEERLY et alii (1973) observaram um efeito positivo apesar de não significativo da adição de lisina sobre a área do olho de lombo.

Diversos autores não observaram nenhum efeito estatísticamente significativo da adição de lisina sobre a área do olho de lombo discordando do presente ensaio, entre eles SEWELL e PRICE (1962) MEADE et alii (1966a), MEADE et alii (1966b) bem̃ como WAHLSTROM e LIBAL (1974).

Quanto ao comprimento da carcaça não foi observa do nenhum efeito estatisticamente significativo para nenhum dos contrastes testados, concordando os presentes resultados com os observados por SEWELL e PRICE (1962), BROWN et alii (1973) e WAHLSTROM e LIBAL (1974). Houve um efeito de bloco no compri mento de carcaça justificando o delineamento utilizado.

Como no ensaio I, os animais que receberam fare1o de algodão durante o transcorrer do período experimental não apresentaram quaisquer sintomas de intoxicação por gossipol co mo aqueles descritos por SMITH (1957) e LYMAN e WIDMER (1966). 


\section{CONCLUSOES}

$$
6.1
$$

Os resultados obtidos no Ensaio I mostraram que a utilização do farelo de algodão como fonte protéica sem suplementação de lisina para suínos em crescimento e acabamento não é recomendável, em razão dos resultados negativos obtidos para ganho de peso, conversão alimentar, espessura do toicinho, porcentagem do pernil e ārea do olho de lombo.

$$
6.2 \text {. }
$$

O Ensaio I mostrou que o farelo de algodão pode constituir até $50 \%$ da fonte protéica da ração com ótimos resul tados, quando a outra metade é constituída de farelo de soja. Percentagens mais elevadas de farelo de algodão na ração causa ram piores desempenhos, principalmente na fase de crescimento.

$$
6.3 .
$$

No Ensaio II a adição de lisina a rações tendo o farelo de algodão como fonte protéica exclusiva teve um efeito positivo sobre o ganho de peso, o consumo de ração e a conversão alimentar. A área do olho de lombo aumentou com a adição de 
$0,2 \%$ de 1 isina, e a porcentagem de pernil aumentou igualmente com a adição de 0,2 e $0,4 \%$ de 1 isina.

6.4 .

A adição de lisina a rações possuíndo como fonte protéica $75 \%$ de farelo de algodão mais $25 \%$ de farelo de soja, durante o período total de ensaio, não teve efeito sobre o ganho de peso. O consumo aumentou e a conversão alimentar melhorou com a adição de $0,2 \%$, enquanto entre as características de carcaças estudadas, somente a área do olho de lombo melhorou com a adição de 0,2 e $0,4 \%$ de 1 isina.

6.5 .

Os resultados obtidos no presente trabalho permi tem indicar o farelo de algodão como alimento protéico em rações de suínos em crescimento e acabamento, sendo que o uso do farelo de algodão, como fonte exclusiva de proteína, pode ser recomendado, desde que a ração seja suplementada com $0,4 \%$ de lisina. Quando o farelo de algodão constituir $75 \%$ da fonte pro téica a ração deverá ser suplementada com $0,2 \%$ de 1 isina. 
7. SUMMARY

The use of cottonseed meal in rations for swine was studied in two feeding experiments. In the first experiment, soybean meal was substituted by increasing levels of cottonseed meal as protein source $(100: 0 ; 75: 25 ; 50: 50 ; 25: 75$; and $0: 100$, respectively). Thirty "three-cross" barrows (Yorkshire $x$ Landra ce $x$ Wessex) were alloted to the 5 treatments according to weight. The experiment lasted 91 days and the initial and final average weights were 23.57 and $91.14 \mathrm{~kg}$, respectively. Rations and water were given individualy "ad libitum". The rations had $16 \% \mathrm{CP}$ during the growing period (23.57 to $55-60 \mathrm{~kg})$ and $13 \% \mathrm{CP}$ during the finish period 55-60 to $91.14 \mathrm{~kg}$ ). At the end of the trial it was observed that increasing cottonseed meal levels resulted in a negative quadratic effect in gain of weight $(P<0.05)$ and a negative quadratic effect in feed efficiency $(P<0.05)$. The worst feed efficiency was obtained in the treatments 4 and 5 . The treatment 5 was significantly $(P<0.05)$ inferior to the others. Regression analyses did not show any significative effect of treatment on carcass dressing percentage and length, but had a negative linear effect on the backfat thickness $(P<0.05)$, percentage of ham $(P<0.01)$ and loin eye area $(P<0.01)$.

The percentage of ham in treatment 5 was significantly inferior $(\mathrm{P}<0.05)$ to the others. The treatment 4 was 
significantly inferior $(P<0.05)$ to treatment 2 but not to treatments 1 and 3 . The loin eye area in treatment 5 was signifi cantly inferior $(P<0.05)$ to the others.

In the second trial the effect of lysine of studied using the following treatments: $\mathrm{T}_{1}$ - Soybean mea1; $\mathrm{T}_{2}{ }^{-}$ Cottonseed mea1; $\mathrm{T}_{3}$ - Cottonseed meal + $0.2 \% 1 \mathrm{ysine;} \quad \mathrm{T}_{4}$ Cottonseed meal $1+0.4 \%$ lysine; $\mathrm{T}_{5}-75 \%$ cottonseed meal $+25 \%$ soybean meal; $\mathrm{T}_{6}-75 \%$ cottonseed meal $+0.2 \% 1$ ysine and $\mathrm{T}_{7}$ $75 \%$ cottonseed meal $+25 \%$ soybean meal $+0.4 \%$ lysine. The trial was conducted during 91 days and initial and final average weights were 18.75 and $87.16 \mathrm{~kg}$, respectively. The animals and your manegement were similar to the first trial. The addition of lysine resulted in a linear positive effect $(P<0.01)$ in weight gain and feed consuption in the treatments with cottonseed meal as the exclusive protein source. There was a positive quadratic $(P<0.05)$ on feed conversion. The treatment 4 was significantly superior than treatment 3 and this superior to treatment 2 in the rate of gain weight $(P<0.05)$. The feed conversion and feed consumption in treatments 3 and 4 were superior to treatment $2(\mathrm{P}<0.05)$. Treatment 6 resulted in an increase in consumption, which was statisticaly superior to treatment 5 in feed conversion $(P<0.05)$. The loin eye area had a significant linear increase $(P<0.05)$ with the addition of lysine and treatment 6 and 7 were significantly superior $(\mathrm{P}<0.05)$ to treatment 5 .

Under the conditions of these experiments the results indicate that cottonseed meal as exclusive source of protein for growing and finishing pigs must be supplemented with $0.4 \%$ of lysine. When the cottonseed meal represents $75 \%$ of the total protein source, a $0.2 \%$ lysine addition is required. 
ABCS - ASSOCIAÇÃO BRASILEIRA DE CRIADORES DE SUINOS, 1973. Método brasileiro de classificação de carcaças. Estrela. 14p. (Publicação técnica, n²).

AGUIRRE, A., H.D. WALLACE e G.E. COMBS, 1960. Effect of lysine supplementation of high-gossypol cottonseed oil meal rations for baby pigs. Journal Animal Science. Albany, 19:1246 (abs.).

AMERICAN OIL CHEMIST'S SOCIETY, 1974. Official and tentative methods of the American Oil Chemist's Society. Chicago. p.7-58.

BALIGA, B.P. e C.M. LYMAN, 1957. Preliminary report on, the nutritional significance of bound gossypol in cottonseed meat. Journal Oil Chemist's Society. Champaign, 34:21-24.

BARBOSA, C., 1969. Toxidez de gossipol em vārias espécies de animais e sua influência sobre a utilização do farelo de a1godão nas rações. Zootecnia. São Paulo, $\underline{2}(2): 39-54$.

BARRENTINE, B.F., 1966. Use of ferrous iron to inactivate gossypol in rations laying hens and swine. In: Conference on Inactivation of Gossypol with Salts, 1966. Anais. Memphis, The National Cottonseed Products Association. p.174-177. BELL, J.T. e L.M. LARSEN, 1967. High-protein cottonseed meal for growing swine. Journal Animal Science. Albany, 26:904 (abs.). 
BELL, J.M. e L.O. VOLDENG, 1968. Further observations on lysine and protein requirements of 23 to 89 kilogram pigs. Canadian Journal Animal Science. Ottawa, 48:251-261.

BLAIR, R., J.B. DENT, P.R. ENGLISH e J.R. RAEBURN, 1969. Protein, lysine and feed intake levels effects on pig growth. I- Main effects. Journal Agricultural Science. Cambridge, 72:379-400.

BRAHAM, J.E., R. BRESSANI, N.R. ESCOBAR e A. AGUIRRE, 1962. Uso de la torta de semilla de algodon en raciones balanceadas para cerdos en proceso de creciniento. Turrialba, $\underline{12}(2)$ : $75-79$.

BRAUDE, R., 1960. Preliminary experiments with DL-1ysine and DL-methionine as supplements to rations of growing pigs. In: Proceedings Pfizer European Agricultural Research Conference, Lucerne, 1960. Sandwich, Kent, Pfizer Ltd. p.1-8.

BRESSANI, R., L.G. ELIAS, J.E. BRAHAM e R. JARQUIM, 1968. Uso de recursos alimenticios centroamericanos para el fomento de la industria animal. I- Composicion quimica y contenido de gossypol de harina de torta de semilla de algodon elaboradas en el area. Turrialba, 13:391-396.

BROWN, H.W., B.G. HARMON e A.H. JENSEN, 1973. Lys ine requirements of the finishing pig for maximum carcass leanness. Journal Animal Science, Albany, $\underline{37}(5): 1159-1164$.

BUITRAGO, J.A., CORZO, M. e I. JIMENEZ P., 1970. La torta de algodon en alimentacion de cerdos. II- Comparicion de tres tortas de algodon en raciones para cerdos en crescimiento y acabado. Revista Instituto Colombiano Agropecuario, Bogotá, $\underline{5}(2): 103-106$.

BUITRAGO, J.A., I. JIMENEZ P., H.B. OBANDO, J.H. MANER e A. B. MONCADA, 1977. Utilizacion de torta (harina) de algodon en alimentacion de cerdos. Cali, ICA/CIAT. 35p. (Série ES-25). CARROL, W.E., J.L. KRIDER e F.N. ANDREWS, 1962. Swine production. 3a.ed. New York, McGraw-Hill. 433p. 
CLAWSON, A.J., F.H. SMITH, J.C. OSBORNE e E.R. BARRICK, 1961. Effect of protein source, autoclaving, and lysine supplementation on gossypol toxicity. Journal Animal Science. Albany, 20 : $547-552$.

CRAMPTON, E.W. e L. E. HARRIS, 1969. Applied animal nutrition. 2a.ed. San Francisco, W.H. Freeman. 749p.

CRESWELL, D.C., H.D. WALlACE, G.E. COMBS, A.Z. PALMER e R. L. WEST, 1975. Lysine and triptophan in diets for boars and barrows. Journal Animal Science, Albany, $\underline{40}(1): 167$ (abs.).

CUNHA T.J., H.D. WALLACE, G.E. COMBS e K.L. DURRANCE, 1974 . Swine Production in Florida, Florida, Tallahassee. $\quad 275 \mathrm{p}$. (Bulletin $n^{\circ}$ 21).

DAVEY, R.J. e L.T. FROBISH, 1975. Diet protein sequence and added lysine for G-F swine. Journal Animal Science. Albany, $\underline{41}(1): 311$ (abs.).

DAVIDSON, R.M., L.G. YOUNG e 0.0. THOMAS, 1962. Effect of lysine additions to a barley, barley-soybean meal ration for growing and fattening swine. Journal Animal Science. Albany, 21:670 (abs.) .

DYER, I.A., J.T. HARRISON, W.S. NICHOLSON JR. e A.E. CULLISON, 1952. Penicillin, lysine, methionine and fish solubles supplement a corn-degossypolized cottonseed meal ration for weanling pigs. Journal Animal Science. Albany, 11:465-473. ENSMINGER, M.E., 1970. Swine science. 4a.ed. Danville, Interstate Printers. $881 \mathrm{p}$.

FETUGA, B.L., G.M. BABATUMDE e V.A. OYENUGA, 1975. Protein levels in diets for European pigs in the tropics. 2- The effects of lysine and methionine supplementation on the protein requirement of growing pigs. Animal Production. Edinburgh, 20: $147-157$.

GERMANN, A., F.O. E.T.MERTZ e W. M.BEESON, 1958. Revaluation of 1-lysine requirement of weanling pigs. Journal Animal Science, 
A1bany, 17:52-61.

GONZALEZ, E.P. e A.A. AQUILERA, 1967. Alimentacion de cerdos en crecimiento con niveles altos de harinolina en las raciones. Tecnica Pecuaria Mexico, Mexico D.F., $\underline{2}(9): 15-18$.

HAINES, C.E., H.D. WALLACE e M. ROGER, 1957. The value of soybean oil meal, sow gossypol (degossypolysed) solvent processed cottonseed meal and various blends thereof in the ration of growing fattening swine. Journal Animal Science. Albany, $16: 12-19$.

HALE, F. e C.M. LYMAN, 1961. Lysine supplementation of sorghum grain-cottonseed meal rations for growing-fattening pigs. Journal Animal Science. Albany, 20:734-736.

HALE, F., C.M. LYMAN e H.A. SMITH, 1958. Use of cottonseed meal in swine rations. Dallas, Texas Agricultural Experiment Station. 14p. (Bulletin, n:898).

HAYS, V.W., 1968. Nutritional and management effects on performance and carcass measurements. In: TOPEL, D.G., ed. The pork industry: problems and progress. Ames, Iowa States University Press. p.67-76.

HINTZ, H.F. e H. HEITMAN JR., 1967. Amino acid and vitamin supplementation to barley-cottonseed meal diets for growingfinishing swine. Journal Animal Science. Albany, 26 :474-478.

HOLLEY, K.T., W.S. HARMS, R.W. STORHERR e W.G. STEPHEN, 1955. Cottonseed meal in swine and rabbit rations. Athens, Georgia Agricultural Experiment Station. 27p. (Mimeograph series, $n \cdot 12)$.

HUTCHINSON, H.D., A.H. JENSEN, S.W. TERRIL e D.E. BECKER, 1957. The lysine requirement of the weanling pig. Journal Animal Science. Albany, 16:558.

IVAN, M., D.J. FARRELL e T.N. EDEY, 1975. Nutritional evaluation of wheat. 3- Effects of supplementation with lysine, threonine of diets based on wheat containing $13 \%$ crude protein on the 
performance of pigs. Animal Production. Edinburgh, 20:267 276 .

JARQUIN, R., M. GONZALEZ, R. OLIVA, L.A. LAMM, L.G. ELIAS e R. BRESSANI, 1968. Estudio del uso de harina de semilla de algodón en el crecimiento y engorde de cerdos. Archivos. Latinoamericanos de Nutricion. Caracas, 18:39-63.

JURGENS, D.B., C.A. HUDMAN, A.N. ADAMS e E.R. PEO JR., 1967. Influence of a dietary supplement of lysine fed at two levels of protein on growth feed efficiency and carcass characteristics of swine. Journal Animal Science. Albany, 26 (1):323-327. KNABE, D.A., T.D. TANKSLEY JR., C.M. CATER e J.H. HESBY, 1975. Effect of lysine fiber and free gossypol in CSM-supplemented growing swine diets. Journal Animal Science. Albany, $\underline{41}(1)$ : 317 (abs.).

LARSEN, L.M. e J.T. BELL, 1967. Compensatory growth of pigs following lysine deficiency. Journal Animal Science. Albany, 26 $: 904$ (abs.).

LYMAN, C.M. e C. WIDMER, 1966. Mode of action, sites of concentration, and metabolic fate of gossypol and gossypol like compounds. In: Conference on Inactivation of Gossypol with Salts, Memphis, 1966. Anais. Memphis, The National Cottonseed Products Association. p.43-53.

LYMAN, C.M., 1966. The effect of gossypol and gossypol-1ike com pounds upon swine in the presence and absence of iron salts and/or protein of high biological value. In: Conference on Inactivation of Gossypol with Salts, Memphis, 1966. Anais. Memphis, The National Cottonseed Products Association. p.147156 .

MCWARD, G.W., D.E. BECKER, H.W. NORTON, S.W. TERRILL e A. H. JENSEN, 1959. The lysine requirement of weaning swine at two levels of dietary protein. Journal Animal Science. Albany, 19:1059. MAGRUDER, N.D., W.C. SHERMAN e W.M. REYNOLDS, 1961. Evaluation 
of supplemental lysine for practical swine rations. Journal Animal Science. Albany, 20:573-577.

MAYNARD, L.A. e J.K. LOOSLI, 1966. Nutrição Animal. Rio de Janeiro, Freitas Bastos. 549p.

MEADE, R.J., 1956. The influence of triptophan, methionine and lysine supplementation of a corn and soybean oil meal diet on nitrogen balance of growing swine. Journal Animal Science. Albany, 15:288.

MEADE, R.J., W.R. DUKELOW e R.S. GRANT, 1966a. Influence of percent oats in the diet, lysine and methionine supplemen tation and of pelleting on rate and efficiency of gain of growing pigs, and on carcass characteristics. Journal animal Science. Albany, 25:58-63.

MEADE, R.J., W.R. DUKELOW e R.S. GRANT, 1966b. Lysine and methionine additions to corn-soybean meal diets for growing swine: effects on rate and efficiency of gain and carcass characteristics. Journal Animal Science. Albany, 25:78-82.

MERTZ, E.T., D.C. SHELTON e W.M. BEESON, 1949. The amino acid requirements of swine lysine. Journal Animal Science. Alba ny, 8 : $: 524-531$.

MINER, J.J., W.B. CLOVER, P.P. NOLAND e E.L. STEPHENSON, 1955. Amino-acid supplementation of a corn-cottonseed meal diet for growing-fattening swine. Journal Animal Science. Albany, $14: 24-29$.

MONCADA, A.B. e J.H. MANER, 1970. Estudio del nivel de torta de algodón a utilizar en dietas para cerdos y neutralización de sus efectos toxicos mediante en sulfato de hierro. Revista Instituto Colombiano Agropecuario. Bogotá, $\underline{5}(2): 91-$ 102 .

NATIONAL COTTONSEED PRODUCTS ASSOCIATION, 1950 , Feeding practices. Dallas. 40p. (bulletin, n:27).

NATIONAL RESEARCH COUNCIL, 1973. Nutrient requirements_ of 
swine. 7 a.ed. Washington, NRC. 56p. (Nutrient requirements of domestic animals, $n \circ 2)$.

NIELSEN, H.E., V.W. HAYS, V.C. SPEER e D.V. CATRON, 1963. Lysine supplementation of corn and barley-base diets for growingfinishing swine. Journal Animal Science. Albany, 22:454-457. NOLAND, P.R., M. FUNDERBURG, J. ATTEBERRY e K.W. SCOTT, 1968 . Use of glandless cottonseed meal in diets for young pigs. Journal Animal Science. Albany, 27:1319-1321.

OBANDO, H., J. BUITRAGO, A. MONCADA e I. JIMENEZ, 1975. Empleo de torta de algodón para cerdas en gestación y lactancia. Asociación Latinoamericana de Producción Animal. Memoria. Mé xico, DF, 10:7-18.

OROK, E.J., J.P. BOWLAND e C.W.BRIGGS, 1975. Rapseed, peanut and soybean meals as protein supplements with or without added lysine: biological performance and carcass characteristics of pigs and rats. Canadian Journal Animal Science. Otawa, 55: $135-146$.

OSTROWSKI, H., M. PIATEK e K. PIERZCHALA, 1969. Partial and total replacement of soya oil meal by cottonseed oil meal in complete feeds for fattening pigs. Roczniki Nauk RolniczychB, 91:247-261 apud Nutrition Abs. Review, $40(3): 6328,1970$.

PHELPS, R.A., 1966. Increasing the amount and performance of cottonseed protein concentrates in nonruminant rations. In: Conference on Inactivation of Gossypol with Salts, Memphis, 1966. Anais. Memphis, The National Cottonseed Products Association. p.5-9.

PIMENTEL GOMES, F., 1976. Curso de estatística experimental. 6a. ed. São Paulo, Nobel. 430p.

POND, W.G. e J.H. MANER, 1974. Swine production in temperate and tropical environments. San Francisco, W.H. Freeman.646p. REIMER, D., R.J.MEADE e R.S. GRANT, 1964. Barley rations for swine. III- Lysine and methionine supplementation: effects on 
rate and efficiency of gain, and on carcass characteristics. Journal Animal Science. Albany, 23:404-408.

RERAT, A., 1972. Protein nutrition, and metabolism in the growing pig. Nutrition Abs. Review. Aberdeen, 42(1):13-39.

RODRIGUES, A.J., 1972. Utilização do farelo de algodão em substituição total e parcial ao farelo de soja na alimentação de suínos em crescimento e acabamento. São Paulo, FMVZ/USP. 87p. (Tese de Doutoramento).

RODRIGUES, A.J., M.A.C. ALMEIDA, F. BACCARI. M.BECKER e F.P. LI MA, 1969. Adição de lisina e metionina, em ração para suínos, com duas fontes de cálcio e fósforo. Boletim de Indústria Animal. São Paulo, 26:107-118.

SEERLEY, R.W., C.E. MEEKS, H.C. Mc CAMPBELL e R.D. SCARTH, 1973. Effects of feeding lysine in solution to growing pigs and rats. Journal Animal Science. Albany, 37:(1):91-94.

SEWELL, R.F., B.C. KEEN e J.L. CARMON, 1957. The value of various blends of soybean oil meal, peanut oil meal, and degossypolized cottonseed oil meal as protein supplements in swine rations. Journal Animal Science. Albany, 16:357-363.

SEWELL, R.F. e D.E. PRICE, 1962. Lysine supplementation on swine finishing rations. Journal Animal Science. Albany, 21:378 (abs.) .

SHARDA, D.P., D.C. MAHAN e R.F. WILSON, 1976. Limiting amino acids in low-protein corn-soybean meal diets for growingfinishing swine. Journal Animal Science. Albany, 42 (5):11751181 .

SHELTON, D.C., W.M. BEESON e E.T. MERTZ, 1951. Quantitative 1lysine requirement of weanling pig. Archives of Biochemistry. New York, 30:1-5.

SMITH, H.A., 1957. The pathology of gossypol poisoning. American Journal of Pathology. Boston, 33:353-365. 
SMITH, F.H. e A.J. CLAWSON, 1965. Effect of diet on accumulation of gossypol in the organs of swine. Journal of Nutrition, Bethesda, 87:317-321.

SOLDEVILA, M. e R.J. MEADE, 1964. Barley rations for swine. IIThe influence of 1-1ysine and DL-methionine supplementation of barley-soybean meal diets upon rate and efficiency of gain and upon nitrogen retention of growing swine. Journal Anima1 Science. Albany, 23:397-403.

STEVENSON, J.W., C.A. CAMBELL e C.M. KINEAID, 1965. Methods of reducing cottonseed meal toxicity for swine. Journal Anima1 Science. Albany, 24:290.

STOCKLAND, W.L., R.J. MEADE e J.W. NORDSTROM, 1971. 1ysine, methio nine and tryptophan supplementation of a corn meat and bone meal diet for growing swine. Journal Animal Science. Albany, $\underline{32}(2): 262-267$.

TANKSLEY JR., T.D., 1970. Use of cottonseed meal in swine rations. Feedstuffs. Minneapolis, 42(16):22-23.

VIANA, S.P., J.P. CARVALHO, J.J.B. FARIA e J.B.O. SANTOS, 1976. Emprego de farelo de algodão em rações para suínos. In: Reunião Anual da Sociedade Brasileira de Zootecnia, 13a. Sa1vador. Anais. Viçosa, SBA, 1976. p.180.

WAHLSTROM, R.C. e G.W. LIBAL, 1974. Gain feed efficiency and carcass characteristics of swine fed supplemental lysine and methionine in corn soybean meal diets during the growing and finishing periods. Journal Animal Science. Albany, $\underline{38}(6)$ :12611265 .

WAHLSTROM, R.C., A.R. TAYLOR e R.W. SEERLEY, 1971. Effects of lysine in the drinking water of growing swine. Journa1. Anima1 Science. Albany, 30:368-373.

WALLACE, H.D., T.J. CUNHA e G.E. COMBS, 1955. Low-gossypol cottonseed meal as a source of protein for swine. Gainesville, F1orida Agrâcultura1 Experiment Station, 26p. (Bulletin, $\mathrm{n}^{\circ}$ $566)$. 
108.

9. APENDICE 
109.

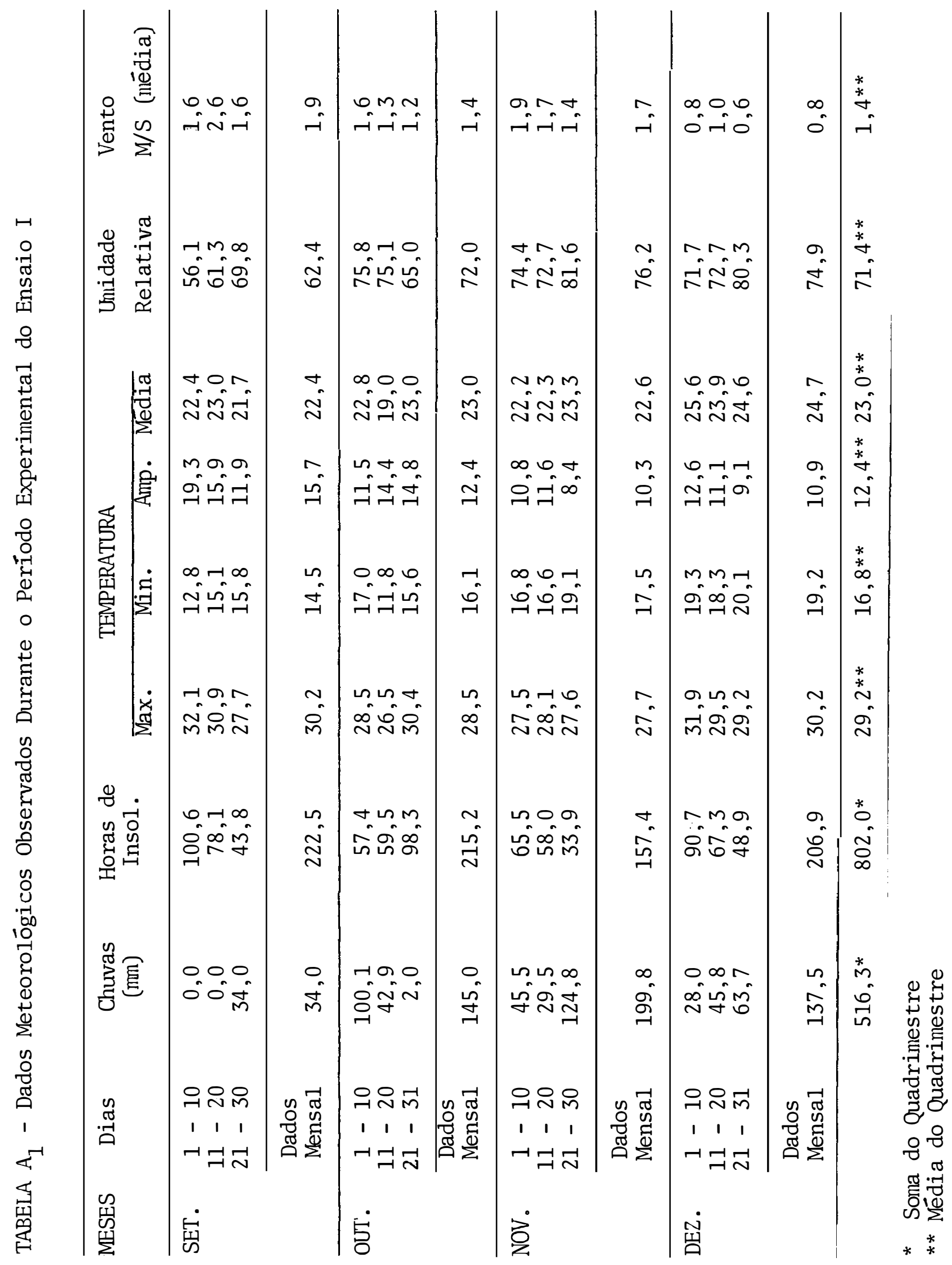




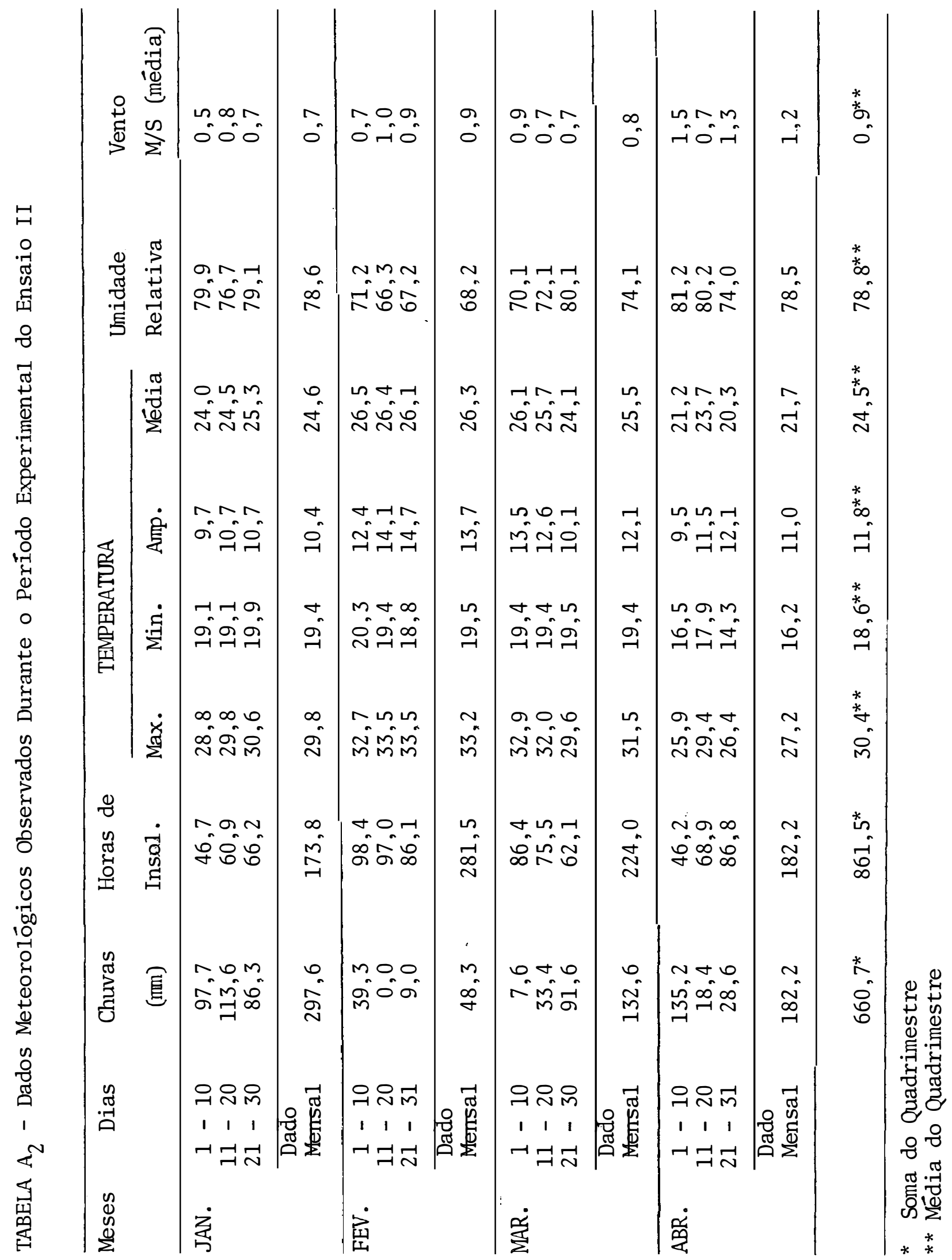




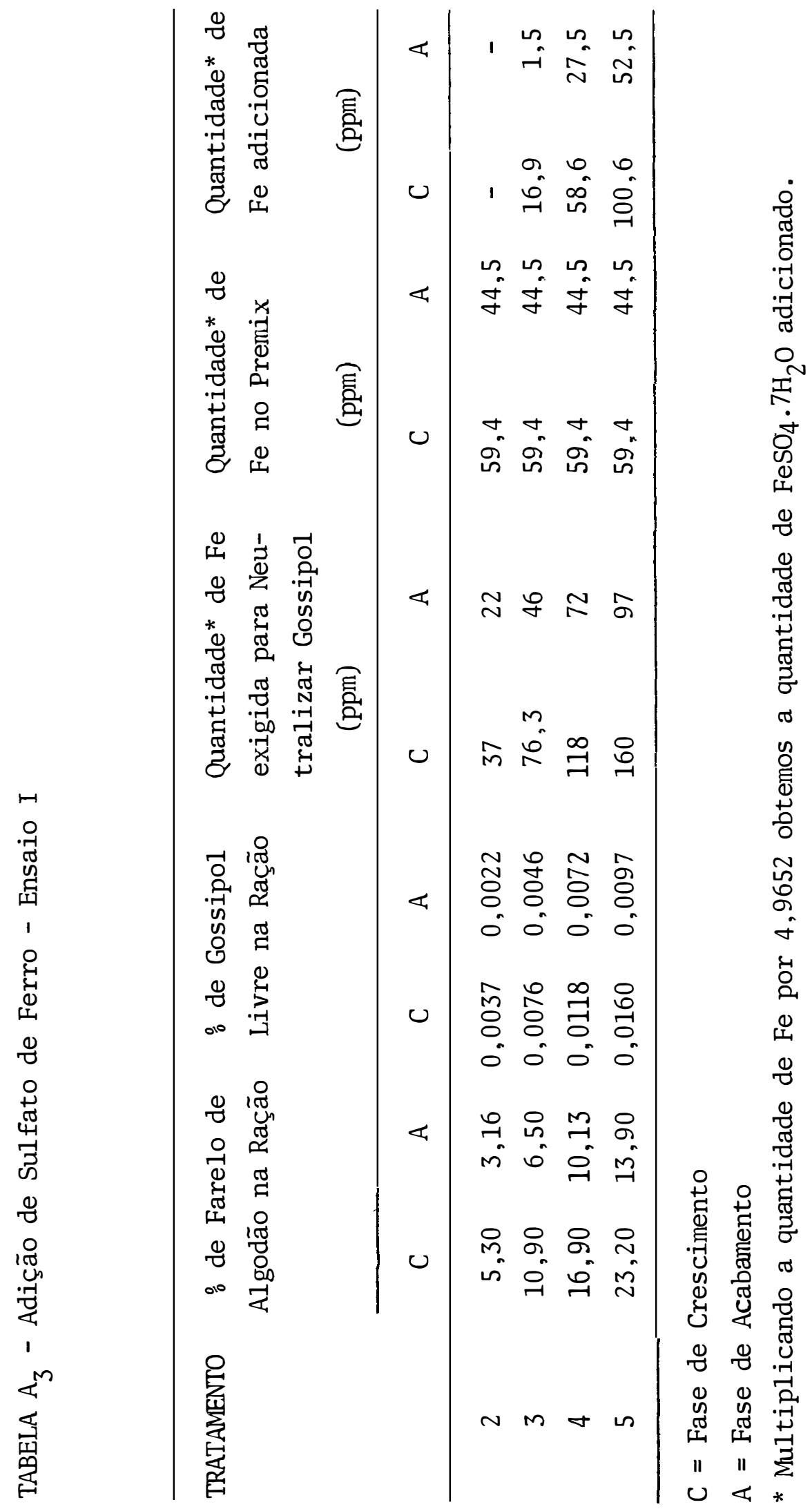


112.

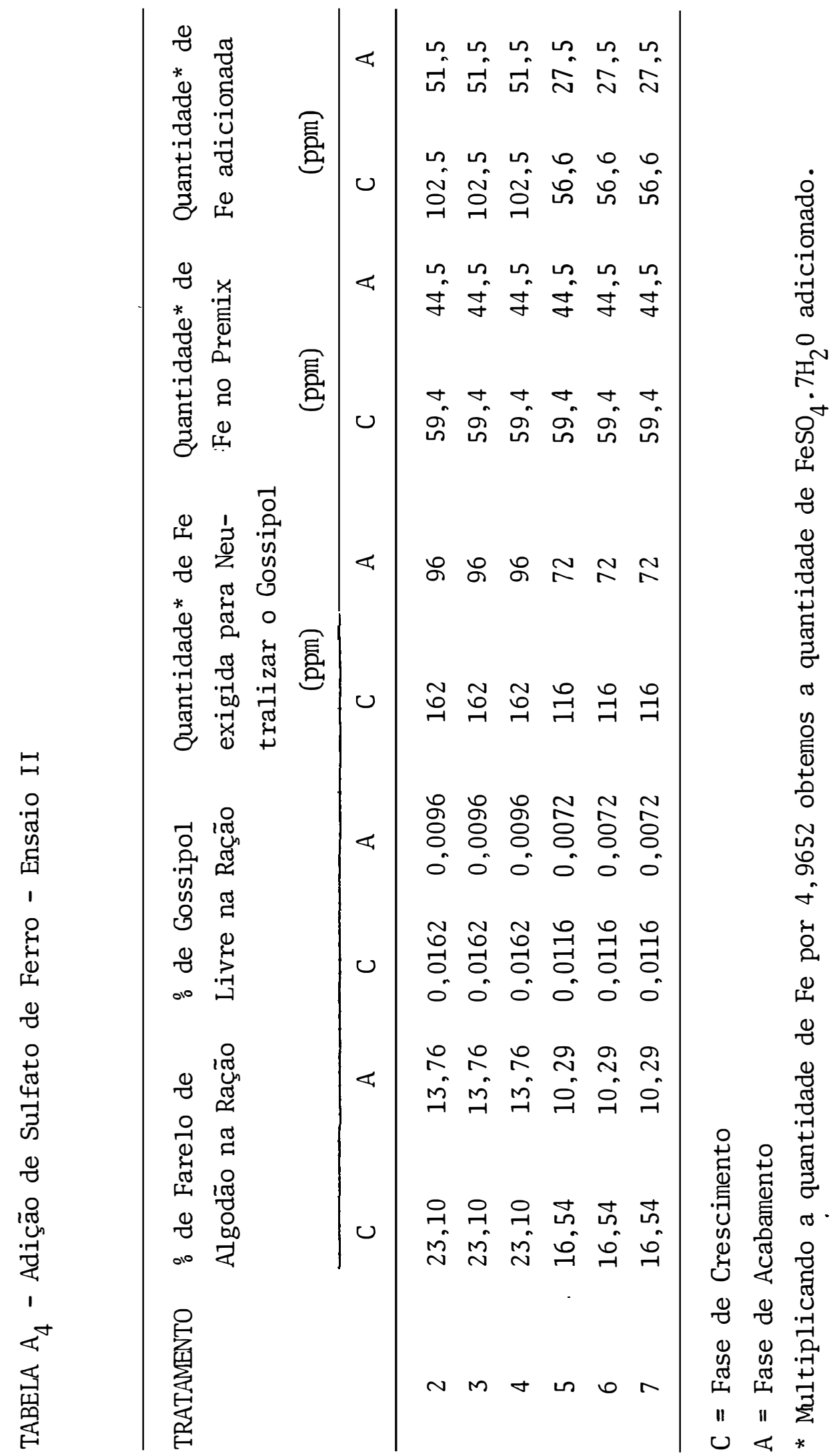


113 .

TABELA $A_{5}$ - Pesos Individuais dos Animais $(\mathrm{kg})$ Durante o Período Experimental Ensaio I

\begin{tabular}{|c|c|c|c|c|c|c|c|c|c|}
\hline TRAT . & BLOCO & $16 / 9$ & $30 / 9$ & $14 / 10$ & $28 / 10$ & $11 / 11$ & $25 / 11$ & $9 / 12$ & $16 / 12$ \\
\hline \multirow[t]{2}{*}{1} & $\begin{array}{l}1 \\
2 \\
3 \\
4 \\
5 \\
6 \\
\end{array}$ & $\begin{array}{l}26,0 \\
25,0 \\
24,0 \\
24,0 \\
24,5 \\
20,0 \\
\end{array}$ & $\begin{array}{l}38,0 \\
34,5 \\
34,0 \\
35,0 \\
37,5 \\
29,5 \\
\end{array}$ & $\begin{array}{l}50,0 \\
46,0 \\
46,5 \\
46,5 \\
51,5 \\
40,5 \\
\end{array}$ & $\begin{array}{l}60,0 \\
57,0 \\
56,5 \\
58,0 \\
65,0 \\
52,5 \\
\end{array}$ & $\begin{array}{l}72,5 \\
65,5 \\
62,5 \\
69,0 \\
80,0 \\
63,0 \\
\end{array}$ & $\begin{array}{l}83,0 \\
76,0 \\
72,5 \\
77,0 \\
90,5 \\
73,0 \\
\end{array}$ & $\begin{array}{r}96,0 \\
86,0 \\
81,0 \\
88,0 \\
105,0 \\
81,0 \\
\end{array}$ & $\begin{array}{r}102,5 \\
92,5 \\
86,0 \\
92,5 \\
110,0 \\
87,0 \\
\end{array}$ \\
\hline & $\begin{array}{l}\text { Total } \\
\text { Média } \\
\end{array}$ & $\begin{array}{r}143,5 \\
23,92 \\
\end{array}$ & $\begin{array}{c}208,5 \\
34,75 \\
\end{array}$ & $\begin{array}{r}281,0 \\
46,84 \\
\end{array}$ & $\begin{array}{r}349,0 \\
58,7 \\
\end{array}$ & $\begin{array}{r}412,5 \\
68,75 \\
\end{array}$ & $\begin{array}{r}474,0 \\
79,0 \\
\end{array}$ & $\begin{array}{r}537,0 \\
89,50 \\
\end{array}$ & $\begin{array}{r}570,5 \\
95,09 \\
\end{array}$ \\
\hline 2 & $\begin{array}{c}1 \\
2 \\
3 \\
4 \\
5 \\
6 \\
\text { Tota1 } \\
\text { Média } \\
\end{array}$ & $\begin{array}{c}28,0 \\
26,0 \\
23,0 \\
23,0 \\
20,0 \\
20,0 \\
140,5 \\
23,42 \\
\end{array}$ & $\begin{array}{c}38,0 \\
36,5 \\
34,0 \\
33,0 \\
30,0 \\
30,5 \\
202,0 \\
33,67 \\
\end{array}$ & $\begin{array}{c}50,5 \\
48,5 \\
45,0 \\
44,5 \\
40,5 \\
42,0 \\
271,0 \\
45,17 \\
\end{array}$ & $\begin{array}{c}60,0 \\
60,5 \\
56,5 \\
55,0 \\
51,5 \\
52,0 \\
335,5 \\
55,92 \\
\end{array}$ & $\begin{array}{c}71,0 \\
71,0 \\
68,5 \\
67,0 \\
62,5 \\
62,5 \\
402,5 \\
67,68 \\
\end{array}$ & $\begin{array}{r}84,5 \\
82,0 \\
79,0 \\
75,0 \\
72,0 \\
72,5 \\
465,0 \\
77,5 \\
\end{array}$ & $\begin{array}{c}95,5 \\
95,0 \\
90,0 \\
85,0 \\
83,5 \\
81,5 \\
530,0 \\
88,42 \\
\end{array}$ & $\begin{array}{r}100,0 \\
98,0 \\
96,5 \\
85,0 \\
88,5 \\
85,0 \\
554,0 \\
92,34 \\
\end{array}$ \\
\hline \multirow[t]{2}{*}{3} & $\begin{array}{l}1 \\
2 \\
3 \\
4 \\
5 \\
6 \\
\end{array}$ & $\begin{array}{l}27,0 \\
24,0 \\
23,5 \\
23,5 \\
22,5 \\
22,5 \\
\end{array}$ & $\begin{array}{l}29,0 \\
34,0 \\
32,0 \\
33,0 \\
32,5 \\
32,5\end{array}$ & $\begin{array}{l}52,5 \\
47,0 \\
40,0 \\
43,5 \\
45,0 \\
46,5 \\
\end{array}$ & $\begin{array}{l}67,0 \\
59,0 \\
50,0 \\
53,0 \\
54,0 \\
57,0 \\
\end{array}$ & $\begin{array}{l}77,5 \\
72,0 \\
60,0 \\
65,0 \\
66,0 \\
67,0 \\
\end{array}$ & $\begin{array}{l}85,0 \\
84,0 \\
69,0 \\
75,0 \\
77,0 \\
77,5 \\
\end{array}$ & $\begin{array}{r}100,0 \\
95,0 \\
78,5 \\
84,5 \\
89,0 \\
89,0 \\
\end{array}$ & $\begin{array}{r}106,0 \\
102,0 \\
82,0 \\
89,0 \\
95,5 \\
95,0 \\
\end{array}$ \\
\hline & $\begin{array}{l}\text { Total } \\
\text { Média } \\
\end{array}$ & $\begin{array}{r}143,0 \\
23,83 \\
\end{array}$ & $\begin{array}{r}203,0 \\
33,83 \\
\end{array}$ & $\begin{array}{r}274,50 \\
45,75 \\
\end{array}$ & $\begin{array}{r}340,0 \\
56,67 \\
\end{array}$ & $\begin{array}{r}407,5 \\
67,92 \\
\end{array}$ & $\begin{array}{r}467,5 \\
77,92 \\
\end{array}$ & $\begin{array}{r}536,0 \\
89,33 \\
\end{array}$ & $\begin{array}{c}569,5 \\
94,92 \\
\end{array}$ \\
\hline \multirow[t]{2}{*}{4} & $\begin{array}{l}1 \\
2 \\
3 \\
4 \\
5 \\
6 \\
\end{array}$ & $\begin{array}{l}28,0 \\
24,5 \\
23,5 \\
22,5 \\
21,5 \\
20,5 \\
\end{array}$ & $\begin{array}{l}38,0 \\
32,5 \\
31,0 \\
31,0 \\
28,5 \\
30,0 \\
\end{array}$ & $\begin{array}{l}51,5 \\
42,0 \\
40,0 \\
42,0 \\
37,5 \\
39,0 \\
\end{array}$ & $\begin{array}{l}65,0 \\
52,5 \\
48,0 \\
55,0 \\
45,0 \\
50,0 \\
\end{array}$ & $\begin{array}{l}76,5 \\
65,0 \\
56,0 \\
68,0 \\
55,0 \\
59,0 \\
\end{array}$ & $\begin{array}{l}92,0 \\
75,0 \\
62,0 \\
78,5 \\
63,5 \\
69,5 \\
\end{array}$ & $\begin{array}{r}105,5 \\
85,5 \\
71,0 \\
90,5 \\
73,0 \\
73,5 \\
\end{array}$ & $\begin{array}{r}110,0 \\
89,5 \\
73,0 \\
96,5 \\
77,5 \\
79,5 \\
\end{array}$ \\
\hline & $\begin{array}{l}\text { Total } \\
\text { Média } \\
\end{array}$ & $\begin{array}{r}140,5 \\
23,42 \\
\end{array}$ & $\begin{array}{r}191,0 \\
31,83 \\
\end{array}$ & $\begin{array}{r}252,0 \\
42,00 \\
\end{array}$ & $\begin{array}{r}315,5 \\
52,58 \\
\end{array}$ & $\begin{array}{r}379,5 \\
63,25 \\
\end{array}$ & $\begin{array}{r}440,5 \\
73,42 \\
\end{array}$ & $\begin{array}{r}499,0 \\
83,17 \\
\end{array}$ & $\begin{array}{r}526,0 \\
87,67 \\
\end{array}$ \\
\hline 5 & $\begin{array}{l}1 \\
2 \\
3 \\
4 \\
5 \\
6 \\
\end{array}$ & $\begin{array}{l}27,5 \\
24,0 \\
23,5 \\
22,0 \\
22,0 \\
20,5 \\
\end{array}$ & $\begin{array}{l}33,0 \\
30,0 \\
30,0 \\
30,0 \\
30,0 \\
30,0 \\
\end{array}$ & $\begin{array}{l}43,5 \\
37,0 \\
40,0 \\
40,0 \\
40,0 \\
41,0 \\
\end{array}$ & $\begin{array}{l}54,0 \\
46,0 \\
49,5 \\
51,0 \\
51,5 \\
53,0 \\
\end{array}$ & $\begin{array}{l}64,0 \\
56,5 \\
57,5 \\
63,0 \\
63,0 \\
67,0 \\
\end{array}$ & $\begin{array}{l}73,0 \\
66,5 \\
65,0 \\
72,0 \\
71,5 \\
80,0 \\
\end{array}$ & $\begin{array}{l}84,0 \\
78,5 \\
73,5 \\
83,5 \\
82,5 \\
89,0 \\
\end{array}$ & $\begin{array}{l}86,0 \\
83,5 \\
75,5 \\
87,0 \\
88,0 \\
94,0 \\
\end{array}$ \\
\hline & $\begin{array}{l}\text { Total } \\
\text { Média }\end{array}$ & $\begin{array}{r}139,5 \\
23,25 \\
\end{array}$ & $\begin{array}{r}183,0 \\
30,50 \\
\end{array}$ & $\begin{array}{c}241,5 \\
40,25 \\
\end{array}$ & $\begin{array}{r}305,0 \\
50,83 \\
\end{array}$ & $\begin{array}{r}371,0 \\
61,83\end{array}$ & $\begin{array}{r}428,0 \\
71,34 \\
\end{array}$ & $\begin{array}{c}491,5 \\
81,92 \\
\end{array}$ & $\begin{array}{r}514,0 \\
85,67 \\
\end{array}$ \\
\hline
\end{tabular}


114 .

TABELA A 6 - Ganho de Peso Individual (kg) por Período de 14 Dias - Ensaio I

\begin{tabular}{|c|c|c|c|c|c|c|c|c|}
\hline TRAT. & BLOCO & $0-14$ & $14-28$ & $28-42$ & $42-56$ & $56-70$ & $70-84$ & $84-91 *$ \\
\hline \multirow[t]{2}{*}{1} & $\begin{array}{l}1 \\
2 \\
3 \\
4 \\
5 \\
6 \\
\end{array}$ & $\begin{array}{r}12,0 \\
9,5 \\
10,0 \\
11,0 \\
13,0 \\
9,5 \\
\end{array}$ & $\begin{array}{l}12,0 \\
11,5 \\
12,5 \\
11,5 \\
14,0 \\
11,0\end{array}$ & $\begin{array}{l}10,0 \\
11,0 \\
10,0 \\
11,5 \\
13,5 \\
12,0 \\
\end{array}$ & $\begin{array}{r}12,5 \\
8,5 \\
6,0 \\
11,0 \\
15,0 \\
10,5 \\
\end{array}$ & $\begin{array}{l}10,5 \\
10,5 \\
10,0 \\
10,0 \\
10,5 \\
10,0 \\
\end{array}$ & $\begin{array}{r}13,0 \\
10,0 \\
8,5 \\
9,0 \\
14,5 \\
8,0 \\
\end{array}$ & $\begin{array}{l}6,5 \\
6,5 \\
5,0 \\
4,5 \\
5,0 \\
6,0 \\
\end{array}$ \\
\hline & $\begin{array}{l}\text { Media } \\
\mathrm{kg} / \mathrm{dia}\end{array}$ & $\begin{array}{c}10,83 \\
0,774 \\
\end{array}$ & $\begin{array}{c}12,09 \\
0,864 \\
\end{array}$ & $\begin{array}{r}11,33 \\
0,809 \\
\end{array}$ & $\begin{array}{c}10,58 \\
0,756 \\
\end{array}$ & $\begin{array}{c}10,25 \\
0,732 \\
\end{array}$ & $\begin{array}{c}10,50 \\
2 \quad 0,750 \\
\end{array}$ & $\begin{array}{l}5,58 \\
0,798 \\
\end{array}$ \\
\hline \multirow[t]{2}{*}{2} & $\begin{array}{l}1 \\
2 \\
3 \\
4 \\
5 \\
6 \\
\end{array}$ & $\begin{array}{l}10,0 \\
10,5 \\
11,0 \\
10,0 \\
10,0 \\
10,0\end{array}$ & $\begin{array}{l}12,5 \\
12,0 \\
11,0 \\
11,5 \\
10,5 \\
11,5\end{array}$ & $\begin{array}{r}9,5 \\
12,0 \\
11,5 \\
10,5 \\
11,0 \\
10,0 \\
\end{array}$ & $\begin{array}{l}11,0 \\
10,5 \\
12,0 \\
12,0 \\
11,0 \\
10,5\end{array}$ & $\begin{array}{r}13,5 \\
11,0 \\
10,5 \\
8,0 \\
9,5 \\
10,0 \\
\end{array}$ & $\begin{array}{r}11,0 \\
13,0 \\
11,0 \\
10,0 \\
11,5 \\
9,0 \\
\end{array}$ & $\begin{array}{l}4,5 \\
3,0 \\
6,5 \\
0,0 \\
5,0 \\
4,5 \\
\end{array}$ \\
\hline & $\begin{array}{l}\text { Média } \\
\mathrm{kg} / \mathrm{dia}\end{array}$ & $\begin{array}{c}10,25 \\
0,732 \\
\end{array}$ & $\begin{array}{c}11,50 \\
0,821 \\
\end{array}$ & $\begin{array}{r}10,75 \\
0,768 \\
\end{array}$ & $\begin{array}{c}11,17 \\
0,798 \\
\end{array}$ & $\begin{array}{c}10,42 \\
0,744 \\
\end{array}$ & $\begin{array}{c}10,92 \\
4 \quad 0,780 \\
\end{array}$ & $\begin{array}{l}3,92 \\
0,560 \\
\end{array}$ \\
\hline \multirow[t]{2}{*}{3} & $\begin{array}{l}1 \\
2 \\
3 \\
4 \\
5 \\
6 \\
\end{array}$ & $\begin{array}{r}12,0 \\
10,0 \\
8,5 \\
9,5 \\
10,0 \\
10,0 \\
\end{array}$ & $\begin{array}{r}13,5 \\
13,0 \\
8,0 \\
10,5 \\
12,5 \\
14,0 \\
\end{array}$ & $\begin{array}{r}14,5 \\
12,0 \\
10,0 \\
9,5 \\
9,0 \\
10,5 \\
\end{array}$ & $\begin{array}{l}10,5 \\
13,0 \\
10,0 \\
12,0 \\
12,0 \\
10,0\end{array}$ & $\begin{array}{r}7,5 \\
12,0 \\
9,0 \\
10,0 \\
11,0 \\
10,5 \\
\end{array}$ & $\begin{array}{r}15,0 \\
11,0 \\
9,5 \\
9,5 \\
12,0 \\
11,5 \\
\end{array}$ & $\begin{array}{l}6,0 \\
7,0 \\
3,5 \\
4,5 \\
6,5 \\
6,0 \\
\end{array}$ \\
\hline & $\begin{array}{l}\text { Média } \\
\text { kg/dia }\end{array}$ & $\begin{array}{c}10,0 \\
0,714 \\
\end{array}$ & $\begin{array}{r}11,92 \\
0,851 \\
\end{array}$ & $\begin{array}{c}10,92 \\
0,780 \\
\end{array}$ & $\begin{array}{c}11,25 \\
0,804 \\
\end{array}$ & $\begin{array}{c}10,00 \\
0,714 \\
\end{array}$ & $\begin{array}{c}11,42 \\
+\quad 0,815 \\
\end{array}$ & $\begin{array}{l}5,58 \\
0,798 \\
\end{array}$ \\
\hline \multirow[t]{2}{*}{4} & $\begin{array}{l}1 \\
2 \\
3 \\
4 \\
5 \\
6 \\
\end{array}$ & $\begin{array}{r}10,0 \\
8,0 \\
7,5 \\
8,5 \\
7,0 \\
9,5 \\
\end{array}$ & $\begin{array}{r}13,5 \\
9,5 \\
9,0 \\
11,0 \\
9,0 \\
9,0 \\
\end{array}$ & $\begin{array}{r}13,5 \\
10,5 \\
8,0 \\
13,0 \\
7,5 \\
11,0 \\
\end{array}$ & $\begin{array}{r}11,5 \\
12,5 \\
8,0 \\
13,0 \\
10,0 \\
9,0 \\
\end{array}$ & $\begin{array}{r}15,5 \\
10,0 \\
6,0 \\
10,5 \\
8,5 \\
10,5 \\
\end{array}$ & $\begin{array}{r}13,5 \\
10,5 \\
9,0 \\
12,0 \\
9,5 \\
4,0 \\
\end{array}$ & $\begin{array}{l}4,5 \\
4,0 \\
2,0 \\
6,0 \\
4,5 \\
6,0 \\
\end{array}$ \\
\hline & $\begin{array}{l}\text { Média } \\
\text { kg/dia }\end{array}$ & $\begin{array}{l}8,58 \\
0,613 \\
\end{array}$ & $\begin{array}{c}10,17 \\
0,726 \\
\end{array}$ & $\begin{array}{c}10,58 \\
0,756 \\
\end{array}$ & $\begin{array}{c}10,67 \\
0,762 \\
\end{array}$ & $\begin{array}{c}10,17 \\
0,726 \\
\end{array}$ & $\begin{array}{ll} & 9,75 \\
5 & 0,696 \\
\end{array}$ & $\begin{array}{l}4,5 \\
0,643 \\
\end{array}$ \\
\hline \multirow[t]{2}{*}{5} & $\begin{array}{l}1 \\
2 \\
3 \\
4 \\
5 \\
6 \\
\end{array}$ & $\begin{array}{l}5,5 \\
6,0 \\
6,5 \\
8,0 \\
8,0 \\
9,5 \\
\end{array}$ & $\begin{array}{r}10,5 \\
7,0 \\
10,0 \\
10,0 \\
10,0 \\
11,0 \\
\end{array}$ & $\begin{array}{r}10,5 \\
9,0 \\
9,5 \\
11,0 \\
11,5 \\
12,0 \\
\end{array}$ & $\begin{array}{r}10,0 \\
10,5 \\
8,0 \\
12,0 \\
11,5 \\
14,0 \\
\end{array}$ & $\begin{array}{r}9,0 \\
10,0 \\
7,5 \\
9,0 \\
8,5 \\
13,0 \\
\end{array}$ & $\begin{array}{r}11,0 \\
12,0 \\
8,5 \\
11,5 \\
11,0 \\
9,5 \\
\end{array}$ & $\begin{array}{l}2,0 \\
5,0 \\
2,0 \\
3,5 \\
5,5 \\
4,5 \\
\end{array}$ \\
\hline & $\begin{array}{l}\text { Média } \\
\mathrm{kg} / \mathrm{dia}\end{array}$ & $\begin{array}{l}7,25 \\
0,518 \\
\end{array}$ & $\begin{array}{l}9,75 \\
0,696 \\
\end{array}$ & $\begin{array}{c}10,58 \\
0,756 \\
\end{array}$ & $\begin{array}{c}11,0 \\
0,786 \\
\end{array}$ & $\begin{array}{l}9,5 \\
0,678 \\
\end{array}$ & $\begin{array}{cc} & 10,58 \\
8 & 0,756 \\
\end{array}$ & $\begin{array}{l}3,75 \\
0,536 \\
\end{array}$ \\
\hline
\end{tabular}

* Período de 7 dias. 
TABELA $A_{7}$ - Consuno Individual (kg) por Período de 14 Dias - Ensaio I

\begin{tabular}{|c|c|c|c|c|c|c|c|c|}
\hline TRAT. & BLOCO & $0-14$ & $14-28$ & $28-42$ & $42-56$ & $56-70$ & $70-84$ & $84-91$ \\
\hline \multirow[t]{2}{*}{1} & $\begin{array}{l}1 \\
2 \\
3 \\
4 \\
5 \\
6\end{array}$ & $\begin{array}{l}31,1 \\
24,0 \\
24,3 \\
25,3 \\
29,8 \\
23,0\end{array}$ & $\begin{array}{l}34,8 \\
26,4 \\
34,0 \\
32,5 \\
38,5 \\
37,3\end{array}$ & $\begin{array}{l}34,2 \\
29,6 \\
32,2 \\
32,2 \\
42,4 \\
34,5\end{array}$ & $\begin{array}{l}41,6 \\
33,0 \\
26,0 \\
35,8 \\
48,4 \\
37,4\end{array}$ & $\begin{array}{l}44,3 \\
34,7 \\
43,9 \\
37,7 \\
49,8 \\
36,1\end{array}$ & $\begin{array}{l}46,8 \\
37,7 \\
39,8 \\
36,3 \\
46,5 \\
35,4\end{array}$ & $\begin{array}{l}22,0 \\
16,9 \\
18,7 \\
17,3 \\
23,8 \\
19,4\end{array}$ \\
\hline & $\begin{array}{l}\text { Média } \\
\text { kg/dia }\end{array}$ & $\begin{array}{r}26,23 \\
1,874 \\
\end{array}$ & $\begin{array}{r}33,92 \\
2,424 \\
\end{array}$ & $\begin{array}{r}34,18 \\
2,442 \\
\end{array}$ & $\begin{array}{r}37,03 \\
2,645 \\
\end{array}$ & $\begin{array}{r}41,08 \\
2,934 \\
\end{array}$ & $\begin{array}{r}40,42 \\
2,887 \\
\end{array}$ & $\begin{array}{r}19,68 \\
2,811 \\
\end{array}$ \\
\hline \multirow[t]{2}{*}{2} & $\begin{array}{l}1 \\
2 \\
3 \\
4 \\
5 \\
6\end{array}$ & $\begin{array}{l}87,4 \\
29,7 \\
30,1 \\
24,8 \\
23,5 \\
24,5 \\
\end{array}$ & $\begin{array}{l}30,9 \\
34,7 \\
36,8 \\
33,5 \\
31,4 \\
29,8 \\
\end{array}$ & $\begin{array}{l}31,4 \\
35,8 \\
35,6 \\
33,9 \\
33,7 \\
34,4 \\
\end{array}$ & $\begin{array}{l}38,8 \\
39,6 \\
41,1 \\
45,3 \\
36,2 \\
36,3 \\
\end{array}$ & $\begin{array}{l}41,9 \\
41,4 \\
43,0 \\
37,4 \\
37,3 \\
41,1 \\
\end{array}$ & $\begin{array}{l}42,9 \\
42,8 \\
45,3 \\
36,5 \\
40,7 \\
41,1 \\
\end{array}$ & $\begin{array}{r}22,4 \\
17,8 \\
19,8 \\
7,4 \\
17,9 \\
19,8 \\
\end{array}$ \\
\hline & $\begin{array}{l}\text { Média } \\
\text { kg/dia }\end{array}$ & $\begin{array}{r}26,67 \\
1,905 \\
\end{array}$ & $\begin{array}{r}32,85 \\
2,346 \\
\end{array}$ & $\begin{array}{r}34,13 \\
2,438 \\
\end{array}$ & $\begin{array}{r}39,55 \\
2,825 \\
\end{array}$ & $\begin{array}{r}40,35 \\
2,882 \\
\end{array}$ & $\begin{array}{r}41,55 \\
2,968 \\
\end{array}$ & $\begin{array}{r}17,52 \\
2,504 \\
\end{array}$ \\
\hline \multirow[t]{2}{*}{3} & $\begin{array}{l}1 \\
2 \\
3 \\
4 \\
5 \\
6 \\
\end{array}$ & $\begin{array}{l}32,6 \\
30,6 \\
23,6 \\
25,0 \\
27,5 \\
27,9 \\
\end{array}$ & $\begin{array}{l}39,8 \\
34,7 \\
19,0 \\
32,3 \\
32,5 \\
34,9 \\
\end{array}$ & $\begin{array}{l}44,8 \\
37,3 \\
31,5 \\
32,2 \\
33,0 \\
37,2 \\
\end{array}$ & $\begin{array}{l}43,7 \\
45,0 \\
35,4 \\
35,8 \\
38,0 \\
36,5 \\
\end{array}$ & $\begin{array}{l}40,0 \\
46,1 \\
37,4 \\
40,3 \\
40,1 \\
37,8 \\
\end{array}$ & $\begin{array}{l}42,0 \\
42,1 \\
36,3 \\
38,4 \\
41,4 \\
43,2 \\
\end{array}$ & $\begin{array}{l}21,6 \\
20,5 \\
17,7 \\
17,4 \\
21,4 \\
19,7 \\
\end{array}$ \\
\hline & $\begin{array}{l}\text { Média } \\
\text { kg/dia }\end{array}$ & $\begin{array}{r}27,87 \\
1,990 \\
\end{array}$ & $\begin{array}{r}32,20 \\
2,300 \\
\end{array}$ & $\begin{array}{r}36,00 \\
2,571 \\
\end{array}$ & $\begin{array}{r}39,07 \\
2,790 \\
\end{array}$ & $\begin{array}{r}40,28 \\
2,877 \\
\end{array}$ & $\begin{array}{r}40,57 \\
2,898 \\
\end{array}$ & $\begin{array}{r}19,72 \\
2,817 \\
\end{array}$ \\
\hline \multirow[t]{2}{*}{4} & $\begin{array}{l}1 \\
2 \\
3 \\
4 \\
5 \\
6 \\
\end{array}$ & $\begin{array}{l}33,0 \\
28,8 \\
25,9 \\
25,9 \\
19,0 \\
23,4 \\
\end{array}$ & $\begin{array}{l}42,9 \\
34,6 \\
32,4 \\
27,4 \\
28,7 \\
26,2 \\
\end{array}$ & $\begin{array}{l}44,7 \\
38,0 \\
28,0 \\
39,2 \\
29,6 \\
32,8 \\
\end{array}$ & $\begin{array}{l}44,0 \\
43,8 \\
29,3 \\
46,3 \\
33,0 \\
35,8 \\
\end{array}$ & $\begin{array}{l}54,0 \\
41,4 \\
31,0 \\
31,6 \\
37,6 \\
37,4 \\
\end{array}$ & $\begin{array}{l}51,3 \\
39,8 \\
32,3 \\
42,7 \\
37,8 \\
26,5 \\
\end{array}$ & $\begin{array}{l}22,6 \\
19,1 \\
13,5 \\
23,9 \\
17,0 \\
17,3 \\
\end{array}$ \\
\hline & $\begin{array}{l}\text { Media } \\
\text { kg/dia }\end{array}$ & $\begin{array}{l}26,0 \\
1,857 \\
\end{array}$ & $\begin{array}{r}32,03 \\
2,288 \\
\end{array}$ & $\begin{array}{r}35,38 \\
2,527 \\
\end{array}$ & $\begin{array}{r}38,70 \\
2,764 \\
\end{array}$ & $\begin{array}{r}38,83 \\
2,774 \\
\end{array}$ & $\begin{array}{r}38,40 \\
2,743 \\
\end{array}$ & $\begin{array}{r}18,90 \\
2,700 \\
\end{array}$ \\
\hline \multirow[t]{2}{*}{5} & $\begin{array}{l}1 \\
2 \\
3 \\
4 \\
5 \\
6 \\
\end{array}$ & $\begin{array}{l}20,5 \\
16,6 \\
22,1 \\
23,8 \\
24,4 \\
26,0 \\
\end{array}$ & $\begin{array}{l}33,6 \\
23,1 \\
29,0 \\
32,3 \\
33,0 \\
34,7 \\
\end{array}$ & $\begin{array}{l}35,3 \\
30,8 \\
34,3 \\
38,4 \\
37,7 \\
43,7 \\
\end{array}$ & $\begin{array}{l}37,9 \\
42,9 \\
36,4 \\
44,6 \\
40,7 \\
48,2 \\
\end{array}$ & $\begin{array}{l}34,9 \\
44,5 \\
39,0 \\
42,5 \\
38,9 \\
49,5 \\
\end{array}$ & $\begin{array}{l}41,8 \\
48,8 \\
40,5 \\
41,7 \\
41,5 \\
45,4 \\
\end{array}$ & $\begin{array}{l}16,0 \\
16,8 \\
14,8 \\
19,4 \\
20,9 \\
22,4 \\
\end{array}$ \\
\hline & $\begin{array}{l}\text { Média } \\
\text { kg/dia }\end{array}$ & $\begin{array}{r}22,20 \\
1,588 \\
\end{array}$ & $\begin{array}{c}30,95 \\
2,211 \\
\end{array}$ & $\begin{array}{r}36,68 \\
2,620 \\
\end{array}$ & $\begin{array}{r}41,48 \\
2,984 \\
\end{array}$ & $\begin{array}{r}41,55 \\
2,968 \\
\end{array}$ & $\begin{array}{r}43,28 \\
3,092 \\
\end{array}$ & $\begin{array}{r}18,38 \\
2,626 \\
\end{array}$ \\
\hline
\end{tabular}


TABELA $\mathrm{A}_{8}$ - Conversão-Alimentar Individual por Período de 14 Dias - Ensaio I

\begin{tabular}{|c|c|c|c|c|c|c|c|c|}
\hline TRAT. & BLOCO & $0-14$ & $14-28$ & $28-42$ & $42-56$ & $56-70$ & $70-84$ & $84-91$ * \\
\hline \multirow[t]{2}{*}{1} & $\begin{array}{l}1 \\
2 \\
3 \\
4 \\
5 \\
6 \\
\end{array}$ & $\begin{array}{l}2,59 \\
2,53 \\
2,43 \\
2,30 \\
2,29 \\
2,42 \\
\end{array}$ & $\begin{array}{l}2,90 \\
2,29 \\
2,72 \\
2,83 \\
2,75 \\
3,39 \\
\end{array}$ & $\begin{array}{l}3,42 \\
3,69 \\
3,22 \\
2,80 \\
3,14 \\
2,87 \\
\end{array}$ & $\begin{array}{l}3,33 \\
3,88 \\
4,33 \\
3,25 \\
3,23 \\
3,56 \\
\end{array}$ & $\begin{array}{l}4,22 \\
3,30 \\
4,39 \\
3,77 \\
4,74 \\
3,61 \\
\end{array}$ & $\begin{array}{l}3,60 \\
3,77 \\
4,68 \\
4,03 \\
3,21 \\
4,42 \\
\end{array}$ & $\begin{array}{l}3,84 \\
2,60 \\
3,74 \\
3,84 \\
4,76 \\
3,23 \\
\end{array}$ \\
\hline & Média & 2,43 & 2,81 & 3,02 & 3,60 & 4,01 & 3,95 & 3,67 \\
\hline \multirow[t]{2}{*}{2} & $\begin{array}{l}1 \\
2 \\
3 \\
4 \\
5 \\
6 \\
\end{array}$ & $\begin{array}{l}2,74 \\
2,83 \\
2,74 \\
2,48 \\
2,35 \\
2,45\end{array}$ & $\begin{array}{l}2,47 \\
2,89 \\
3,34 \\
2,91 \\
2,99 \\
2,59\end{array}$ & $\begin{array}{l}3,30 \\
2,98 \\
3,09 \\
3,23 \\
3,06 \\
3,44\end{array}$ & $\begin{array}{l}3,53 \\
3,77 \\
3,42 \\
3,77 \\
3,29 \\
3,46\end{array}$ & $\begin{array}{l}3,10 \\
3,76 \\
4,09 \\
4,67 \\
3,93 \\
4,11\end{array}$ & $\begin{array}{l}3,90 \\
3,29 \\
4,12 \\
3,65 \\
3,54 \\
4,57\end{array}$ & $\begin{array}{l}4,98 \\
5,93 \\
3,05 \\
7,40 \\
3,58 \\
4,40\end{array}$ \\
\hline & Média & 2,60 & 2,87 & 3,19 & 3,54 & 3,94 & 3,84 & 4,89 \\
\hline \multirow[t]{2}{*}{3} & $\begin{array}{l}1 \\
2 \\
3 \\
4 \\
5 \\
6\end{array}$ & $\begin{array}{l}2,72 \\
3,06 \\
2,78 \\
2,63 \\
2,75 \\
2,79 \\
\end{array}$ & $\begin{array}{l}2,94 \\
2,67 \\
2,37 \\
3,08 \\
2,60 \\
2,49 \\
\end{array}$ & $\begin{array}{l}3,09 \\
3,11 \\
3,15 \\
3,39 \\
3,67 \\
3,54\end{array}$ & $\begin{array}{l}4,16 \\
3,46 \\
3,54 \\
2,98 \\
3,17 \\
3,65\end{array}$ & $\begin{array}{l}5,33 \\
3,84 \\
4,15 \\
4,03 \\
3,64 \\
3,60\end{array}$ & $\begin{array}{l}2,80 \\
3,83 \\
3,82 \\
4,04 \\
3,45 \\
3,76\end{array}$ & $\begin{array}{l}3,60 \\
2,93 \\
5,06 \\
3,87 \\
3,29 \\
3,28 \\
\end{array}$ \\
\hline & Média & 2,79 & 2,69 & 3,32 & 3,49 & 4,10 & 3,62 & 3,67 \\
\hline \multirow[t]{2}{*}{4} & $\begin{array}{l}1 \\
2 \\
3 \\
4 \\
5 \\
6\end{array}$ & $\begin{array}{l}3,30 \\
3,60 \\
3,05 \\
3,05 \\
2,71 \\
2,46\end{array}$ & $\begin{array}{l}3,18 \\
3,64 \\
3,60 \\
2,49 \\
3,19 \\
2,91\end{array}$ & $\begin{array}{l}3,31 \\
3,62 \\
3,50 \\
3,01 \\
3,95 \\
2,98\end{array}$ & $\begin{array}{l}3,83 \\
3,50 \\
3,66 \\
3,56 \\
3,30 \\
3,98\end{array}$ & $\begin{array}{l}3,48 \\
4,14 \\
5,17 \\
3,01 \\
4,42 \\
3,56\end{array}$ & $\begin{array}{l}3,80 \\
3,79 \\
3,59 \\
3,56 \\
3,98 \\
6,62\end{array}$ & $\begin{array}{l}5,02 \\
4,77 \\
6,75 \\
3,98 \\
3,78 \\
2,88\end{array}$ \\
\hline & Média & 3,03 & 3,17 & 3,39 & 3,64 & 3,96 & 4,22 & 4,53 \\
\hline \multirow[t]{2}{*}{5} & $\begin{array}{l}1 \\
2 \\
3 \\
4 \\
5 \\
6\end{array}$ & $\begin{array}{l}3,73 \\
2,77 \\
3,40 \\
2,97 \\
3,05 \\
2,74\end{array}$ & $\begin{array}{l}3,20 \\
3,30 \\
2,90 \\
3,23 \\
3,30 \\
3,15\end{array}$ & $\begin{array}{l}3,36 \\
3,42 \\
3,61 \\
3,49 \\
3,28 \\
3,63\end{array}$ & $\begin{array}{l}3,79 \\
4,08 \\
4,55 \\
3,72 \\
3,54 \\
3,44\end{array}$ & $\begin{array}{l}3,87 \\
4,45 \\
5,20 \\
4,72 \\
4,58 \\
3,81\end{array}$ & $\begin{array}{l}3,80 \\
4,07 \\
4,76 \\
3,63 \\
3,77 \\
4,78\end{array}$ & $\begin{array}{l}8,00 \\
3,36 \\
7,40 \\
5,54 \\
3,80 \\
4,98\end{array}$ \\
\hline & Média & 3,11 & 3,18 & 3,47 & 3,85 & 4,44 & 4,13 & 5,51 \\
\hline
\end{tabular}

* Período de 7 dias. 


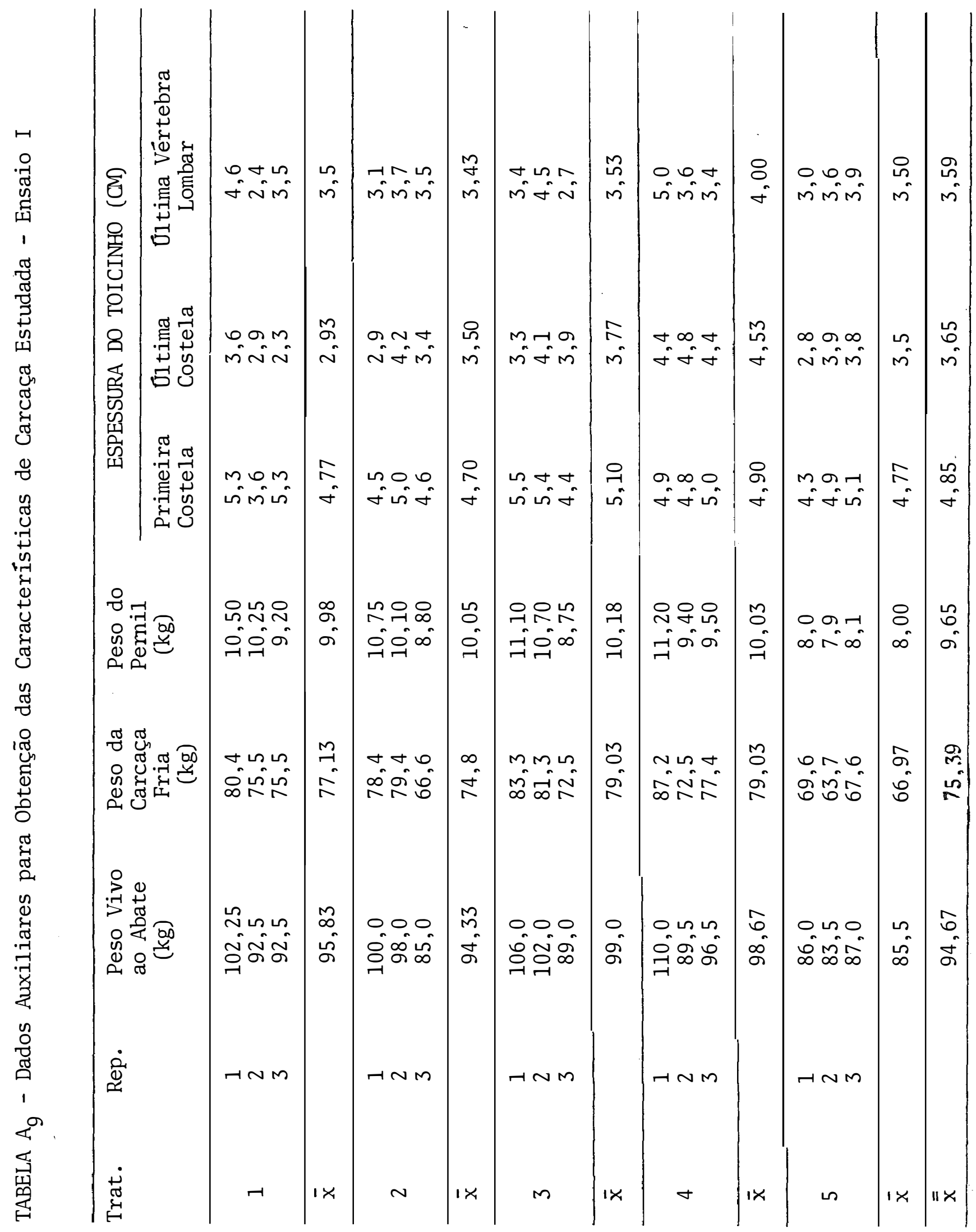


118 .

TABEIA A $A_{10}$ - Ganho de Peso Individual (kg) por Período de 14 dias Ensaio II

\begin{tabular}{|c|c|c|c|c|c|c|c|c|}
\hline TRAT. & BLOCO & $0-14$ & $14-28$ & $28-42$ & $42-56$ & $56-70$ & $70-84$ & $84-91$ * \\
\hline \multirow[t]{2}{*}{1} & $\begin{array}{l}1 \\
2 \\
3 \\
4 \\
\end{array}$ & $\begin{array}{r}7,5 \\
10,0 \\
10,0 \\
10,0 \\
\end{array}$ & $\begin{array}{l}10,0 \\
11,0 \\
10,5 \\
10,5 \\
\end{array}$ & $\begin{array}{l}10,5 \\
13,5 \\
12,5 \\
12,5 \\
\end{array}$ & $\begin{array}{l}13,0 \\
14,0 \\
12,5 \\
12,0 \\
\end{array}$ & $\begin{array}{l}13,0 \\
12,0 \\
14,0 \\
12,5 \\
\end{array}$ & $\begin{array}{l}13,0 \\
13,5 \\
14,5 \\
14,5 \\
\end{array}$ & $\begin{array}{l}7,5 \\
8,0 \\
7,5 \\
6,5 \\
\end{array}$ \\
\hline & $\begin{array}{l}\text { Média } \\
\text { kg/dia }\end{array}$ & $\begin{array}{l}9,35 \\
0,668 \\
\end{array}$ & $\begin{array}{r}10,50 \\
0,750 \\
\end{array}$ & $\begin{array}{r}12,25 \\
0,875 \\
\end{array}$ & $\begin{array}{r}12,87 \\
0,920 \\
\end{array}$ & $\begin{array}{r}12,87 \\
0,920 \\
\end{array}$ & $\begin{array}{r}13,87 \\
0,991 \\
\end{array}$ & $\begin{array}{l}7,37 \\
1,05 \\
\end{array}$ \\
\hline \multirow[t]{2}{*}{2} & $\begin{array}{l}1 \\
2 \\
3 \\
4 \\
\end{array}$ & $\begin{array}{l}3,0 \\
5,0 \\
6,5 \\
3,5 \\
\end{array}$ & $\begin{array}{l}4,0 \\
6,0 \\
6,0 \\
3,5 \\
\end{array}$ & $\begin{array}{l}6,0 \\
5,5 \\
7,5 \\
6,5 \\
\end{array}$ & $\begin{array}{l}8,5 \\
5,5 \\
7,5 \\
6,0 \\
\end{array}$ & $\begin{array}{l}8,5 \\
7,0 \\
7,0 \\
7,5 \\
\end{array}$ & $\begin{array}{r}11,0 \\
7,5 \\
8,5 \\
9,0 \\
\end{array}$ & $\begin{array}{l}6,5 \\
3,0 \\
3,0 \\
4,0 \\
\end{array}$ \\
\hline & $\begin{array}{l}\text { Média } \\
\text { kg/dia }\end{array}$ & $\begin{array}{l}4,50 \\
0,321 \\
\end{array}$ & $\begin{array}{l}4,87 \\
0,384 \\
\end{array}$ & $\begin{array}{l}6,37 \\
0,455 \\
\end{array}$ & $\begin{array}{l}6,87 \\
0,491 \\
\end{array}$ & $\begin{array}{l}7,50 \\
0,536 \\
\end{array}$ & $\begin{array}{l}9,00 \\
0,643 \\
\end{array}$ & $\begin{array}{l}4,12 \\
0,589 \\
\end{array}$ \\
\hline \multirow[t]{2}{*}{3} & $\begin{array}{l}1 \\
2 \\
3 \\
4 \\
\end{array}$ & $\begin{array}{l}8,5 \\
6,0 \\
8,0 \\
4,5 \\
\end{array}$ & $\begin{array}{l}7,5 \\
6,5 \\
9,0 \\
7,0 \\
\end{array}$ & $\begin{array}{r}12,0 \\
11,0 \\
11,0 \\
7,0 \\
\end{array}$ & $\begin{array}{r}12,0 \\
7,0 \\
13,0 \\
8,5 \\
\end{array}$ & $\begin{array}{r}12,0 \\
11,5 \\
11,5 \\
8,5 \\
\end{array}$ & $\begin{array}{l}13,5 \\
14,0 \\
14,0 \\
12,0 \\
\end{array}$ & $\begin{array}{l}7,0 \\
7,5 \\
5,0 \\
6,0 \\
\end{array}$ \\
\hline & $\begin{array}{l}\text { Média } \\
\text { kg/dia }\end{array}$ & $\begin{array}{l}6,75 \\
0,482 \\
\end{array}$ & $\begin{array}{l}9,25 \\
0,660 \\
\end{array}$ & $\begin{array}{c}10,25 \\
0,732 \\
\end{array}$ & $\begin{array}{r}10,12 \\
0,723 \\
\end{array}$ & $\begin{array}{r}10,87 \\
0,777 \\
\end{array}$ & $\begin{array}{r}13,37 \\
0,955 \\
\end{array}$ & $\begin{array}{l}6,37 \\
0,911 \\
\end{array}$ \\
\hline 4 & $\begin{array}{l}1 \\
2 \\
3 \\
4 \\
\end{array}$ & $\begin{array}{l}9,5 \\
9,5 \\
9,5 \\
7,0 \\
\end{array}$ & $\begin{array}{r}10,5 \\
10,0 \\
11,5 \\
9,5 \\
\end{array}$ & $\begin{array}{r}11,5 \\
12,5 \\
13,5 \\
8,5 \\
\end{array}$ & $\begin{array}{l}10,0 \\
13,0 \\
11,5 \\
11,5 \\
\end{array}$ & $\begin{array}{r}9,5 \\
15,0 \\
16,0 \\
10,5 \\
\end{array}$ & $\begin{array}{l}10,0 \\
14,0 \\
12,5 \\
12,5 \\
\end{array}$ & $\begin{array}{l}5,0 \\
6,5 \\
7,0 \\
6,0 \\
\end{array}$ \\
\hline$\cdot$ & $\begin{array}{l}\text { Média } \\
\mathrm{kg} / \text { dia }\end{array}$ & $\begin{array}{l}8,87 \\
0,663 \\
\end{array}$ & $\begin{array}{r}10,37 \\
0,741 \\
\end{array}$ & $\begin{array}{r}11,50 \\
0,821 \\
\end{array}$ & $\begin{array}{r}11,50 \\
0,821 \\
\end{array}$ & $\begin{array}{c}12,75 \\
0,911 \\
\end{array}$ & $\begin{array}{r}12,25 \\
0,875 \\
\end{array}$ & $\begin{array}{l}6,12 \\
0,875 \\
\end{array}$ \\
\hline \multirow[t]{2}{*}{5} & $\begin{array}{l}1 \\
2 \\
3 \\
4 \\
\end{array}$ & $\begin{array}{l}5,0 \\
8,0 \\
8,0 \\
6,0 \\
\end{array}$ & $\begin{array}{r}6,0 \\
11,5 \\
9,5 \\
7,0 \\
\end{array}$ & $\begin{array}{r}7,5 \\
11,5 \\
12,0 \\
6,5 \\
\end{array}$ & $\begin{array}{l}10,0 \\
14,0 \\
12,5 \\
11,0 \\
\end{array}$ & $\begin{array}{r}11,5 \\
14,5 \\
12,5 \\
8,5 \\
\end{array}$ & $\begin{array}{l}11,5 \\
15,0 \\
15,0 \\
10,0 \\
\end{array}$ & $\begin{array}{l}7,5 \\
6,5 \\
4,5 \\
4,5 \\
\end{array}$ \\
\hline & $\begin{array}{l}\text { Média } \\
\text { kg/dia }\end{array}$ & $\begin{array}{l}6,75 \\
0,482 \\
\end{array}$ & $\begin{array}{l}8,50 \\
0,601 \\
\end{array}$ & $\begin{array}{l}9,37 \\
0,670 \\
\end{array}$ & $\begin{array}{r}11,87 \\
0,848 \\
\end{array}$ & $\begin{array}{r}12,87 \\
0,839 \\
\end{array}$ & $\begin{array}{r}12,87 \\
0,920 \\
\end{array}$ & $\begin{array}{l}5,75 \\
0,821 \\
\end{array}$ \\
\hline \multirow[t]{2}{*}{6} & $\begin{array}{r}1 \\
2 \\
3 \\
4 \\
\end{array}$ & $\begin{array}{r}7,5 \\
10,0 \\
9,0 \\
6,5 \\
\end{array}$ & $\begin{array}{l}10,5 \\
11,5 \\
11,5 \\
11,5 \\
\end{array}$ & $\begin{array}{l}11,0 \\
12,5 \\
12,0 \\
11,0 \\
\end{array}$ & $\begin{array}{l}11,5 \\
11,5 \\
12,0 \\
13,0 \\
\end{array}$ & $\begin{array}{l}12,0 \\
17,5 \\
13,0 \\
14,5 \\
\end{array}$ & $\begin{array}{l}11,0 \\
14,5 \\
13,0 \\
14,5 \\
\end{array}$ & $\begin{array}{l}5,0 \\
4,5 \\
5,5 \\
3,0 \\
\end{array}$ \\
\hline & $\begin{array}{l}\text { Média } \\
\text { kg/dia }\end{array}$ & $\begin{array}{l}8,25 \\
0,589 \\
\end{array}$ & $\begin{array}{r}11,25 \\
0,803 \\
\end{array}$ & $\begin{array}{r}11,62 \\
0,830 \\
\end{array}$ & $\begin{array}{r}12,00 \\
0,857 \\
\end{array}$ & $\begin{array}{r}14,25 \\
1,018 \\
\end{array}$ & $\begin{array}{r}13,25 \\
0,946 \\
\end{array}$ & $\begin{array}{l}3,5 \\
0,786 \\
\end{array}$ \\
\hline 7 & $\begin{array}{r}1 \\
2 \\
3 \\
4 \\
\end{array}$ & $\begin{array}{r}10,0 \\
11,0 \\
8,5 \\
8,5 \\
\end{array}$ & $\begin{array}{r}9,5 \\
12,5 \\
4,5 \\
12,0 \\
\end{array}$ & $\begin{array}{l}11,5 \\
11,0 \\
13,0 \\
12,5 \\
\end{array}$ & $\begin{array}{r}8,0 \\
12,0 \\
14,0 \\
11,5 \\
\end{array}$ & $\begin{array}{l}14,0 \\
14,5 \\
13,0 \\
12,0 \\
\end{array}$ & $\begin{array}{l}13,0 \\
13,0 \\
16,0 \\
13,5 \\
\end{array}$ & $\begin{array}{l}6,0 \\
6,5 \\
5,5 \\
5,5 \\
\end{array}$ \\
\hline & $\begin{array}{l}\text { Média } \\
\text { kg/dia }\end{array}$ & $\begin{array}{l}9,50 \\
0,678 \\
\end{array}$ & $\begin{array}{l}9,62 \\
0,678 \\
\end{array}$ & $\begin{array}{r}12,00 \\
0,857 \\
\end{array}$ & $\begin{array}{r}11,37 \\
0,312 \\
\end{array}$ & $\begin{array}{r}13,37 \\
0,955 \\
\end{array}$ & $\begin{array}{r}13,87 \\
0,991 \\
\end{array}$ & $\begin{array}{l}5,87 \\
0,831 \\
\end{array}$ \\
\hline
\end{tabular}

* Período de 7 dias. 
119.

TABELA $A_{11}$ - Pesos Individuais dos Animais $(\mathrm{kg})$ Durante o Período Experimental - Ensaio II

\begin{tabular}{|c|c|c|c|c|c|c|c|c|c|}
\hline TRAT. & BLOCO & $27 / 1$ & $10 / 2$ & $24 / 2$ & $10 / 3$ & $24 / 3$ & $7 / 4$ & $21 / 4$ & $28 / 4$ \\
\hline 1 & $\begin{array}{l}1 \\
2 \\
3 \\
4 \\
\end{array}$ & $\begin{array}{l}19,5 \\
20,0 \\
19,0 \\
16,5 \\
\end{array}$ & $\begin{array}{l}27,0 \\
30,0 \\
29,0 \\
26,5 \\
\end{array}$ & $\begin{array}{l}37,0 \\
41,0 \\
39,5 \\
37,0 \\
\end{array}$ & $\begin{array}{l}47,5 \\
54,5 \\
52,0 \\
49,5 \\
\end{array}$ & $\begin{array}{l}60,5 \\
68,5 \\
64,5 \\
61,5 \\
\end{array}$ & $\begin{array}{l}73,5 \\
80,5 \\
78,5 \\
74,0 \\
\end{array}$ & $\begin{array}{l}86,5 \\
94,0 \\
93,0 \\
88,5 \\
\end{array}$ & $\begin{array}{r}94,0 \\
102,0 \\
100,5 \\
95,0 \\
\end{array}$ \\
\hline & $\begin{array}{l}\text { Total } \\
\text { Média }\end{array}$ & $\begin{array}{l}75,00 \\
18,75 \\
\end{array}$ & $\begin{array}{r}112,50 \\
28,12 \\
\end{array}$ & $\begin{array}{r}154,50 \\
38,62 \\
\end{array}$ & $\begin{array}{r}203,50 \\
50,87 \\
\end{array}$ & $\begin{array}{r}255,00 \\
63,75 \\
\end{array}$ & $\begin{array}{r}306,50 \\
76,62 \\
\end{array}$ & $\begin{array}{r}362,00 \\
90,50\end{array}$ & $\begin{array}{r}391,50 \\
97,87\end{array}$ \\
\hline 2 & $\begin{array}{l}1 \\
2 \\
3 \\
4 \\
\end{array}$ & $\begin{array}{l}20,0 \\
19,5 \\
19,0 \\
16,5 \\
\end{array}$ & $\begin{array}{l}23,0 \\
24,5 \\
25,5 \\
20,0 \\
\end{array}$ & $\begin{array}{l}27,0 \\
30,5 \\
31,5 \\
23,5 \\
\end{array}$ & $\begin{array}{l}33,0 \\
36,0 \\
39,0 \\
30,0 \\
\end{array}$ & $\begin{array}{l}41,5 \\
41,5 \\
46,5 \\
36,0 \\
\end{array}$ & $\begin{array}{l}50,0 \\
48,5 \\
53,5 \\
43,5 \\
\end{array}$ & $\begin{array}{l}61,0 \\
55,0 \\
62,0 \\
52,5 \\
\end{array}$ & $\begin{array}{l}67,5 \\
58,0 \\
65,0 \\
56,5 \\
\end{array}$ \\
\hline & $\begin{array}{l}\text { Total } \\
\text { Média }\end{array}$ & $\begin{array}{l}75,00 \\
18,75 \\
\end{array}$ & $\begin{array}{l}93,00 \\
23,25 \\
\end{array}$ & $\begin{array}{r}112,50 \\
28,12 \\
\end{array}$ & $\begin{array}{r}138,00 \\
34,50 \\
\end{array}$ & $\begin{array}{r}165,50 \\
41,37 \\
\end{array}$ & $\begin{array}{r}195,50 \\
48,87 \\
\end{array}$ & $\begin{array}{r}230,50 \\
57,62 \\
\end{array}$ & $\begin{array}{r}247,00 \\
61,75 \\
\end{array}$ \\
\hline 3 & $\begin{array}{l}1 \\
2 \\
3 \\
4 \\
\end{array}$ & $\begin{array}{l}21,0 \\
19,0 \\
18,0 \\
17,0 \\
\end{array}$ & $\begin{array}{l}29,5 \\
25,0 \\
26,0 \\
21,5 \\
\end{array}$ & $\begin{array}{l}37,0 \\
31,5 \\
35,0 \\
28,5 \\
\end{array}$ & $\begin{array}{l}49,0 \\
42,5 \\
46,0 \\
35,5 \\
\end{array}$ & $\begin{array}{l}61,0 \\
49,5 \\
59,0 \\
44,0 \\
\end{array}$ & $\begin{array}{l}73,0 \\
61,0 \\
70,5 \\
53,5 \\
\end{array}$ & $\begin{array}{l}86,5 \\
75,0 \\
84,5 \\
64,5 \\
\end{array}$ & $\begin{array}{l}93,5 \\
82,5 \\
89,5 \\
70,5 \\
\end{array}$ \\
\hline & $\begin{array}{l}\text { Total } \\
\text { Média }\end{array}$ & $\begin{array}{l}75,00 \\
18,75 \\
\end{array}$ & $\begin{array}{r}102,00 \\
25,50 \\
\end{array}$ & $\begin{array}{r}132,00 \\
33,00 \\
\end{array}$ & $\begin{array}{r}173,00 \\
43,25 \\
\end{array}$ & $\begin{array}{r}213,50 \\
53,37 \\
\end{array}$ & $\begin{array}{r}258,00 \\
64,50 \\
\end{array}$ & $\begin{array}{r}310,50 \\
77,62 \\
\end{array}$ & $\begin{array}{r}336,00 \\
84,00 \\
\end{array}$ \\
\hline 4 & $\begin{array}{l}1 \\
2 \\
3 \\
4 \\
\end{array}$ & $\begin{array}{l}20,0 \\
19,5 \\
18,5 \\
16,5 \\
\end{array}$ & $\begin{array}{l}29,5 \\
29,0 \\
28,0 \\
23,5 \\
\end{array}$ & $\begin{array}{l}40,0 \\
39,0 \\
39,5 \\
33,0 \\
\end{array}$ & $\begin{array}{l}51,5 \\
51,5 \\
53,0 \\
41,5 \\
\end{array}$ & $\begin{array}{l}61,5 \\
64,5 \\
64,5 \\
53,0 \\
\end{array}$ & $\begin{array}{l}71,0 \\
79,5 \\
80,5 \\
63,5 \\
\end{array}$ & $\begin{array}{l}81,0 \\
93,5 \\
93,0 \\
76,0 \\
\end{array}$ & $\begin{array}{r}86,0 \\
100,0 \\
100,0 \\
82,0 \\
\end{array}$ \\
\hline & $\begin{array}{l}\text { Total } \\
\text { Média }\end{array}$ & $\begin{array}{l}74,50 \\
18,63 \\
\end{array}$ & $\begin{array}{r}110,00 \\
27,50 \\
\end{array}$ & $\begin{array}{r}151,50 \\
37,87 \\
\end{array}$ & $\begin{array}{r}197,50 \\
49,37 \\
\end{array}$ & $\begin{array}{r}243,50 \\
60,87 \\
\end{array}$ & $\begin{array}{r}294,50 \\
73,62 \\
\end{array}$ & $\begin{array}{r}343,50 \\
85,87 \\
\end{array}$ & $\begin{array}{r}368,00 \\
92,00 \\
\end{array}$ \\
\hline 5 & $\begin{array}{l}1 \\
2 \\
3 \\
4 \\
\end{array}$ & $\begin{array}{l}19,0 \\
20,0 \\
18,5 \\
16,5 \\
\end{array}$ & $\begin{array}{l}24,0 \\
28,0 \\
26,5 \\
22,5 \\
\end{array}$ & $\begin{array}{l}30,0 \\
39,5 \\
36,0 \\
29,5 \\
\end{array}$ & $\begin{array}{l}37,5 \\
51,0 \\
48,0 \\
36,0 \\
\end{array}$ & $\begin{array}{l}47,5 \\
65,0 \\
60,5 \\
45,0 \\
\end{array}$ & $\begin{array}{l}59,0 \\
79,5 \\
73,0 \\
53,5 \\
\end{array}$ & $\begin{array}{l}70,5 \\
94,5 \\
88,0 \\
63,5 \\
\end{array}$ & $\begin{array}{r}78,0 \\
101,0 \\
92,5 \\
68,0 \\
\end{array}$ \\
\hline & $\begin{array}{l}\text { Total } \\
\text { Média }\end{array}$ & $\begin{array}{l}74,00 \\
18,50 \\
\end{array}$ & $\begin{array}{r}101,00 \\
25,25 \\
\end{array}$ & $\begin{array}{r}135,00 \\
33,75 \\
\end{array}$ & $\begin{array}{r}172,50 \\
43,12 \\
\end{array}$ & $\begin{array}{r}218,00 \\
54,50 \\
\end{array}$ & $\begin{array}{r}265,00 \\
66,25 \\
\end{array}$ & $\begin{array}{r}316,50 \\
79,12 \\
\end{array}$ & $\begin{array}{r}339,50 \\
84,87 \\
\end{array}$ \\
\hline 6 & $\begin{array}{l}1 \\
2 \\
3 \\
4 \\
\end{array}$ & $\begin{array}{l}20,0 \\
19,0 \\
20,0 \\
18,0 \\
\end{array}$ & $\begin{array}{l}27,5 \\
29,0 \\
29,0 \\
24,5 \\
\end{array}$ & $\begin{array}{l}38,0 \\
40,5 \\
40,5 \\
36,0 \\
\end{array}$ & $\begin{array}{l}49,0 . \\
53,0 \\
52,5 \\
47,0 \\
\end{array}$ & $\begin{array}{l}60,5 \\
64,5 \\
64,5 \\
60,0 \\
\end{array}$ & $\begin{array}{l}72,5 \\
82,0 \\
77,5 \\
74,5 \\
\end{array}$ & $\begin{array}{l}83,5 \\
96,5 \\
90,5 \\
89,0 \\
\end{array}$ & $\begin{array}{r}88,5 \\
101,0 \\
96,0 \\
96,0 \\
\end{array}$ \\
\hline & $\begin{array}{l}\text { Total } \\
\text { Média }\end{array}$ & $\begin{array}{l}77,00 \\
19,25 \\
\end{array}$ & $\begin{array}{r}110,00 \\
27,50 \\
\end{array}$ & $\begin{array}{r}155,00 \\
38,75 \\
\end{array}$ & $\begin{array}{r}201,50 \\
50,37 \\
\end{array}$ & $\begin{array}{r}249,50 \\
62,37 \\
\end{array}$ & $\begin{array}{r}306,50 \\
76,62 \\
\end{array}$ & $\begin{array}{r}359,50 \\
89,87 \\
\end{array}$ & $\begin{array}{r}381,50 \\
95,37 \\
\end{array}$ \\
\hline 7 & $\begin{array}{l}1 \\
2 \\
3 \\
4 \\
\end{array}$ & $\begin{array}{l}21,0 \\
19,0 \\
18,0 \\
16,5 \\
\end{array}$ & $\begin{array}{l}31,0 \\
30,0 \\
26,5 \\
25,0 \\
\end{array}$ & $\begin{array}{l}40,5 \\
42,5 \\
31,0 \\
37,0 \\
\end{array}$ & $\begin{array}{l}52,0 \\
53,5 \\
44,0 \\
49,5 \\
\end{array}$ & $\begin{array}{l}60,0 \\
65,5 \\
58,0 \\
61,0 \\
\end{array}$ & $\begin{array}{l}74,0 \\
80,0 \\
71,0 \\
73,0 \\
\end{array}$ & $\begin{array}{l}87,0 \\
93,0 \\
87,0 \\
86,5 \\
\end{array}$ & $\begin{array}{l}93,0 \\
99,5 \\
92,5 \\
92,0 \\
\end{array}$ \\
\hline & $\begin{array}{l}\text { Total } \\
\text { Média }\end{array}$ & $\begin{array}{l}74,50 \\
18,63\end{array}$ & $\begin{array}{r}112,50 \\
28,12\end{array}$ & $\begin{array}{r}151,00 \\
37,75\end{array}$ & $\begin{array}{r}199,00 \\
49,75\end{array}$ & $\begin{array}{r}244,50 \\
61,12\end{array}$ & $\begin{array}{r}298,00 \\
74,50\end{array}$ & $\begin{array}{r}353,50 \\
88,37\end{array}$ & $\begin{array}{r}377,00 \\
94,25\end{array}$ \\
\hline
\end{tabular}


TABELA $A_{12}$ - Consumo Individual $(\mathrm{kg})$ por Período de 14 dias - Ensaio II

\begin{tabular}{|c|c|c|c|c|c|c|c|c|}
\hline TRAT. & BLOCO & $0-14$ & $14-28$ & $28-42$ & $42-56$ & $56-70$ & $70-84$ & $84-91$ * \\
\hline \multirow[t]{2}{*}{1} & $\begin{array}{l}1 \\
2 \\
3 \\
4 \\
\end{array}$ & $\begin{array}{l}18,9 \\
23,7 \\
21,0 \\
21,9 \\
\end{array}$ & $\begin{array}{l}25,0 \\
30,0 \\
27,2 \\
28,2 \\
\end{array}$ & $\begin{array}{l}27,7 \\
34,3 \\
32,9 \\
31,8 \\
\end{array}$ & $\begin{array}{l}35,5 \\
42,5 \\
35,8 \\
36,4 \\
\end{array}$ & $\begin{array}{l}41,2 \\
40,8 \\
46,3 \\
44,4 \\
\end{array}$ & $\begin{array}{l}43,1 \\
43,6 \\
48,1 \\
46,8 \\
\end{array}$ & $\begin{array}{l}22,3 \\
22,9 \\
24,2 \\
23,6 \\
\end{array}$ \\
\hline & $\begin{array}{l}\text { Média } \\
\text { kg/dia }\end{array}$ & $\begin{array}{r}21,37 \\
1,526 \\
\end{array}$ & $\begin{array}{r}27,60 \\
1,971 \\
\end{array}$ & $\begin{array}{r}31,67 \\
2,260 \\
\end{array}$ & $\begin{array}{r}37,55 \\
2,682 \\
\end{array}$ & $\begin{array}{r}43,17 \\
3,084 \\
\end{array}$ & $\begin{array}{r}45,40 \\
3,243 \\
\end{array}$ & $\begin{array}{r}23,25 \\
3,321 \\
\end{array}$ \\
\hline \multirow[t]{2}{*}{2} & $\begin{array}{l}1 \\
2 \\
3 \\
4 \\
\end{array}$ & $\begin{array}{l}13,2 \\
19,8 \\
18,9 \\
14,0 \\
\end{array}$ & $\begin{array}{l}15,2 \\
22,4 \\
22,6 \\
15,0 \\
\end{array}$ & $\begin{array}{l}18,4 \\
21,4 \\
25,9 \\
17,7 \\
\end{array}$ & $\begin{array}{l}25,4 \\
30,0 \\
31,4 \\
25,1 \\
\end{array}$ & $\begin{array}{l}31,4 \\
30,0 \\
29,8 \\
29,0 \\
\end{array}$ & $\begin{array}{l}38,8 \\
29,7 \\
31,4 \\
34,3 \\
\end{array}$ & $\begin{array}{l}21,4 \\
14,0 \\
13,3 \\
14,8 \\
\end{array}$ \\
\hline & $\begin{array}{l}\text { Média } \\
\text { kg/dia }\end{array}$ & $\begin{array}{r}16,47 \\
1,176 \\
\end{array}$ & $\begin{array}{r}18,80 \\
1,343 \\
\end{array}$ & $\begin{array}{r}20,97 \\
1,498 \\
\end{array}$ & $\begin{array}{r}28,72 \\
2,052 \\
\end{array}$ & $\begin{array}{r}30,05 \\
2,146 \\
\end{array}$ & $\begin{array}{r}33,50 \\
2,396 \\
\end{array}$ & $\begin{array}{r}15,87 \\
2,268 \\
\end{array}$ \\
\hline \multirow[t]{2}{*}{3} & $\begin{array}{l}1 \\
2 \\
3 \\
4 \\
\end{array}$ & $\begin{array}{l}20,5 \\
19,9 \\
21,8 \\
14,4 \\
\end{array}$ & $\begin{array}{l}25,6 \\
22,0 \\
30,9 \\
20,5 \\
\end{array}$ & $\begin{array}{l}32,5 \\
28,9 \\
32,7 \\
21,8 \\
\end{array}$ & $\begin{array}{l}41,6 \\
29,2 \\
40,0 \\
27,4 \\
\end{array}$ & $\begin{array}{l}45,0 \\
39,0 \\
44,7 \\
31,9 \\
\end{array}$ & $\begin{array}{l}49,0 \\
48,0 \\
47,0 \\
36,4 \\
\end{array}$ & $\begin{array}{l}22,1 \\
22,7 \\
21,0 \\
19,2 \\
\end{array}$ \\
\hline & $\begin{array}{l}\text { Média } \\
\text { kg/dia }\end{array}$ & $\begin{array}{r}18,92 \\
1,351 \\
\end{array}$ & $\begin{array}{r}24,75 \\
1,768 \\
\end{array}$ & $\begin{array}{r}28,97 \\
2,070 \\
\end{array}$ & $\begin{array}{r}34,55 \\
2,468 \\
\end{array}$ & $\begin{array}{r}40,15 \\
2,868 \\
\end{array}$ & $\begin{array}{r}45,10 \\
3,221 \\
\end{array}$ & $\begin{array}{r}21,25 \\
3,036 \\
\end{array}$ \\
\hline \multirow[t]{2}{*}{4} & $\begin{array}{l}1 \\
2 \\
3 \\
4 \\
\end{array}$ & $\begin{array}{l}22,0 \\
25,0 \\
24,0 \\
16,7 \\
\end{array}$ & $\begin{array}{l}29,9 \\
32,6 \\
33,9 \\
25,1 \\
\end{array}$ & $\begin{array}{l}31,6 \\
37,6 \\
38,6 \\
25,0 \\
\end{array}$ & $\begin{array}{l}35,3 \\
48,0 \\
42,2 \\
31,6 \\
\end{array}$ & $\begin{array}{l}35,8 \\
54,4 \\
50,0 \\
36,0 \\
\end{array}$ & $\begin{array}{l}35,4 \\
53,8 \\
51,4 \\
41,4 \\
\end{array}$ & $\begin{array}{l}18,5 \\
25,5 \\
26,1 \\
19,6\end{array}$ \\
\hline & $\begin{array}{l}\text { Média } \\
\text { kg/dia }\end{array}$ & $\begin{array}{r}21,92 \\
1,566 \\
\end{array}$ & $\begin{array}{r}30,37 \\
2,170 \\
\end{array}$ & $\begin{array}{r}33,20 \\
2,371 \\
\end{array}$ & $\begin{array}{r}39,27 \\
2,805 \\
\end{array}$ & $\begin{array}{r}44,05 \\
3,146 \\
\end{array}$ & $\begin{array}{r}40,50 \\
3,250 \\
\end{array}$ & $\begin{array}{r}22,42 \\
3,204 \\
\end{array}$ \\
\hline \multirow[t]{2}{*}{5} & $\begin{array}{l}1 \\
2 \\
3 \\
4 \\
\end{array}$ & $\begin{array}{l}13,8 \\
21,3 \\
19,2 \\
16,5 \\
\end{array}$ & $\begin{array}{l}26,0 \\
32,2 \\
29,0 \\
22,1 \\
\end{array}$ & $\begin{array}{l}19,3 \\
38,0 \\
33,2 \\
22,4 \\
\end{array}$ & $\begin{array}{l}31,3 \\
33,9 \\
32,1 \\
30,0 \\
\end{array}$ & $\begin{array}{l}38,5 \\
52,0 \\
48,4 \\
31,4 \\
\end{array}$ & $\begin{array}{l}44,3 \\
52,8 \\
48,2 \\
34,2 \\
\end{array}$ & $\begin{array}{l}22,4 \\
25,9 \\
24,5 \\
18,1 \\
\end{array}$ \\
\hline & $\begin{array}{l}\text { Média } \\
\text { kg/dia }\end{array}$ & $\begin{array}{r}17,70 \\
1,264 \\
\end{array}$ & $\begin{array}{r}27,32 \\
1,952 \\
\end{array}$ & $\begin{array}{r}27,47 \\
1,962 \\
\end{array}$ & $\begin{array}{r}31,80 \\
2,273 \\
\end{array}$ & $\begin{array}{r}42,57 \\
3,041 \\
\end{array}$ & $\begin{array}{r}44,87 \\
3,205 \\
\end{array}$ & $\begin{array}{r}22,72 \\
3,246 \\
\end{array}$ \\
\hline \multirow[t]{2}{*}{6} & $\begin{array}{l}1 \\
2 \\
3 \\
4 \\
\end{array}$ & $\begin{array}{l}18,5 \\
24,1 \\
22,4 \\
18,4 \\
\end{array}$ & $\begin{array}{l}25,8 \\
33,9 \\
33,5 \\
29,4 \\
\end{array}$ & $\begin{array}{l}29,5 \\
38,5 \\
36,8 \\
35,3 \\
\end{array}$ & $\begin{array}{l}45,0 \\
43,0 \\
41,7 \\
39,7 \\
\end{array}$ & $\begin{array}{l}37,8 \\
52,0 \\
46,6 \\
48,6 \\
\end{array}$ & $\begin{array}{l}37,0 \\
51,7 \\
48,4 \\
53,0 \\
\end{array}$ & $\begin{array}{l}19,3 \\
23,8 \\
24,7 \\
24,8 \\
\end{array}$ \\
\hline & $\begin{array}{l}\text { Média } \\
\text { kg/dia }\end{array}$ & $\begin{array}{r}20,85 \\
1,489 \\
\end{array}$ & $\begin{array}{r}30,65 \\
2,189 \\
\end{array}$ & $\begin{array}{r}35,02 \\
2,501 \\
\end{array}$ & $\begin{array}{r}42,35 \\
3,025 \\
\end{array}$ & $\begin{array}{r}46,25 \\
3,303 \\
\end{array}$ & $\begin{array}{r}47,52 \\
3,395 \\
\end{array}$ & $\begin{array}{r}23,15 \\
3,307 \\
\end{array}$ \\
\hline \multirow[t]{2}{*}{7} & $\begin{array}{l}1 \\
2 \\
3 \\
4 \\
\end{array}$ & $\begin{array}{l}20,0 \\
24,9 \\
21,8 \\
19,0 \\
\end{array}$ & $\begin{array}{l}28,6 \\
29,3 \\
20,8 \\
28,6 \\
\end{array}$ & $\begin{array}{l}29,4 \\
31,9 \\
33,2 \\
32,9 \\
\end{array}$ & $\begin{array}{l}31,0 \\
40,0 \\
39,0 \\
39,0 \\
\end{array}$ & $\begin{array}{l}42,4 \\
46,6 \\
45,0 \\
44,5 \\
\end{array}$ & $\begin{array}{l}45,0 \\
47,4 \\
47,6 \\
46,4 \\
\end{array}$ & $\begin{array}{l}21,8 \\
24,2 \\
21,5 \\
22,4 \\
\end{array}$ \\
\hline & $\begin{array}{l}\text { Média } \\
\text { kg/dia }\end{array}$ & $\begin{array}{r}21,42 \\
1,530 \\
\end{array}$ & $\begin{array}{r}26,82 \\
1,916 \\
\end{array}$ & $\begin{array}{r}31,85 \\
2,275 \\
\end{array}$ & $\begin{array}{r}37,25 \\
2,669 \\
\end{array}$ & $\begin{array}{c}44,62 \\
3,187 \\
\end{array}$ & $\begin{array}{r}46,60 \\
3,328 \\
\end{array}$ & $\begin{array}{r}22,47 \\
3,580 \\
\end{array}$ \\
\hline
\end{tabular}

* Período de 7 dias. 
TABELA $A_{13}$ - Conversão Alimentar Individual por Período de 14 dias Ensaio II

\begin{tabular}{|c|c|c|c|c|c|c|c|c|}
\hline TRAT. & BLOCO & $0-14$ & $14-28$ & $28-42$ & $42-56$ & $56-70$ & $70-84$ & $84-91$ * \\
\hline \multirow[t]{2}{*}{1} & $\begin{array}{l}1 \\
2 \\
3 \\
4 \\
\end{array}$ & $\begin{array}{l}2,52 \\
2,37 \\
2,10 \\
2,19 \\
\end{array}$ & $\begin{array}{l}2,50 \\
2,73 \\
2,59 \\
2,68 \\
\end{array}$ & $\begin{array}{l}2,64 \\
2,54 \\
2,63 \\
2,54 \\
\end{array}$ & $\begin{array}{l}2,73 \\
3,03 \\
2,86 \\
3,03 \\
\end{array}$ & $\begin{array}{l}3,17 \\
3,40 \\
3,31 \\
3,55\end{array}$ & $\begin{array}{l}3,31 \\
3,22 \\
3,32 \\
3,23 \\
\end{array}$ & $\begin{array}{l}2,97 \\
2,86 \\
3,23 \\
3,63 \\
\end{array}$ \\
\hline & Média & 2,29 & 2,62 & 2,59 & 2,91 & 3,36 & 3,27 & 3,17 \\
\hline \multirow[t]{2}{*}{2} & $\begin{array}{l}1 \\
2 \\
3 \\
4 \\
\end{array}$ & $\begin{array}{l}4,40 \\
3,96 \\
2,91 \\
4,00 \\
\end{array}$ & $\begin{array}{l}3,80 \\
3,73 \\
3,77 \\
4,28 \\
\end{array}$ & $\begin{array}{l}3,15 \\
3,89 \\
3,45 \\
2,69 \\
\end{array}$ & $\begin{array}{l}3,34 \\
5,45 \\
4,17 \\
4,18 \\
\end{array}$ & $\begin{array}{l}3,69 \\
4,28 \\
4,26 \\
3,87 \\
\end{array}$ & $\begin{array}{l}3,53 \\
3,96 \\
3,69 \\
3,81 \\
\end{array}$ & $\begin{array}{l}3,29 \\
4,67 \\
4,43 \\
3,70 \\
\end{array}$ \\
\hline & Média & 3,82 & 3,90 & 3,30 & 4,29 & 4,02 & 3,75 & 4,02 \\
\hline \multirow[t]{2}{*}{3} & $\begin{array}{l}1 \\
2 \\
3 \\
4 \\
\end{array}$ & $\begin{array}{l}2,41 \\
3,17 \\
2,72 \\
3,20 \\
\end{array}$ & $\begin{array}{l}3,41 \\
3,38 \\
3,43 \\
2,93 \\
\end{array}$ & $\begin{array}{l}2,70 \\
2,63 \\
2,97 \\
3,11 \\
\end{array}$ & $\begin{array}{l}3,47 \\
4,17 \\
3,08 \\
3,22 \\
\end{array}$ & $\begin{array}{l}3,75 \\
3,39 \\
3,89 \\
3,75 \\
\end{array}$ & $\begin{array}{l}3,63 \\
3,43 \\
3,36 \\
3,03\end{array}$ & $\begin{array}{l}3,16 \\
3,03 \\
4,20 \\
3,20 \\
\end{array}$ \\
\hline & Média & 2,87 & 3,29 & 2,85 & 3,48 & 3,69 & 3,62 & 3,40 \\
\hline \multirow[t]{2}{*}{4} & $\begin{array}{l}1 \\
2 \\
3 \\
4\end{array}$ & $\begin{array}{l}2,31 \\
2,63 \\
2,53 \\
2,38\end{array}$ & $\begin{array}{l}2,85 \\
3,26 \\
2,94 \\
2,64\end{array}$ & $\begin{array}{l}2,75 \\
3,00 \\
2,86 \\
2,94\end{array}$ & $\begin{array}{l}3,53 \\
3,69 \\
3,67 \\
2,75\end{array}$ & $\begin{array}{l}3,77 \\
3,63 \\
3,12 \\
3,43\end{array}$ & $\begin{array}{l}3,54 \\
3,84 \\
4,11 \\
3,31\end{array}$ & $\begin{array}{l}3,70 \\
3,92 \\
3,73 \\
3,27\end{array}$ \\
\hline & Média & 2,46 & 2,92 & 2,89 & 3,41 & 3,49 & 3,70 & 3,65 \\
\hline \multirow[t]{2}{*}{5} & $\begin{array}{l}1 \\
2 \\
3 \\
4\end{array}$ & $\begin{array}{l}2,76 \\
2,66 \\
2,40 \\
2,75\end{array}$ & $\begin{array}{l}4,33 \\
2,80 \\
3,05 \\
3,16\end{array}$ & $\begin{array}{l}2,57 \\
3,30 \\
2,77 \\
3,45\end{array}$ & $\begin{array}{l}3,13 \\
2,42 \\
2,57 \\
2,73\end{array}$ & $\begin{array}{l}3,35 \\
3,57 \\
3,87 \\
3,69\end{array}$ & $\begin{array}{l}3,85 \\
3,52 \\
3,21 \\
3,42\end{array}$ & $\begin{array}{l}2,97 \\
3,98 \\
5,44 \\
4,02\end{array}$ \\
\hline & Média & 2,64 & 3,33 & 3,02 & 2,71 & 3,62 & 3,50 & 4,11 \\
\hline \multirow[t]{2}{*}{6} & $\begin{array}{l}1 \\
2 \\
3 \\
4\end{array}$ & $\begin{array}{l}2,47 \\
2,41 \\
2,49 \\
2,83\end{array}$ & $\begin{array}{l}2,45 \\
2,95 \\
2,91 \\
2,56\end{array}$ & $\begin{array}{l}2,68 \\
3,08 \\
3,06 \\
3,21\end{array}$ & $\begin{array}{l}3,91 \\
3,74 \\
3,47 \\
3,05\end{array}$ & $\begin{array}{l}3,15 \\
2,97 \\
3,58 \\
3,35\end{array}$ & $\begin{array}{l}3,36 \\
3,56 \\
3,72 \\
3,65\end{array}$ & $\begin{array}{l}3,86 \\
5,29 \\
4,49 \\
3,54\end{array}$ \\
\hline & Média & 2,55 & 2,72 & 3,01 & 3,54 & 3,26 & 3,58 & 4,29 \\
\hline \multirow[t]{2}{*}{7} & $\begin{array}{l}1 \\
2 \\
3 \\
4 \\
\end{array}$ & $\begin{array}{l}2,00 \\
2,26 \\
2,56 \\
2,23 \\
\end{array}$ & $\begin{array}{l}3,01 \\
2,34 \\
4,62 \\
2,38\end{array}$ & $\begin{array}{l}2,56 \\
2,90 \\
2,55 \\
2,63 \\
\end{array}$ & $\begin{array}{l}3,87 \\
3,33 \\
2,78 \\
3,39 \\
\end{array}$ & $\begin{array}{l}3,03 \\
3,21 \\
3,46 \\
3,71 \\
\end{array}$ & $\begin{array}{l}3,46 \\
3,65 \\
2,97 \\
3,44 \\
\end{array}$ & $\begin{array}{l}3,63 \\
3,72 \\
3,91 \\
4,07 \\
\end{array}$ \\
\hline & Média & 2,26 & 3,09 & 2,66 & 3,35 & 3,35 & 3,38 & 3,83 \\
\hline
\end{tabular}

* Período de 7 dias. 


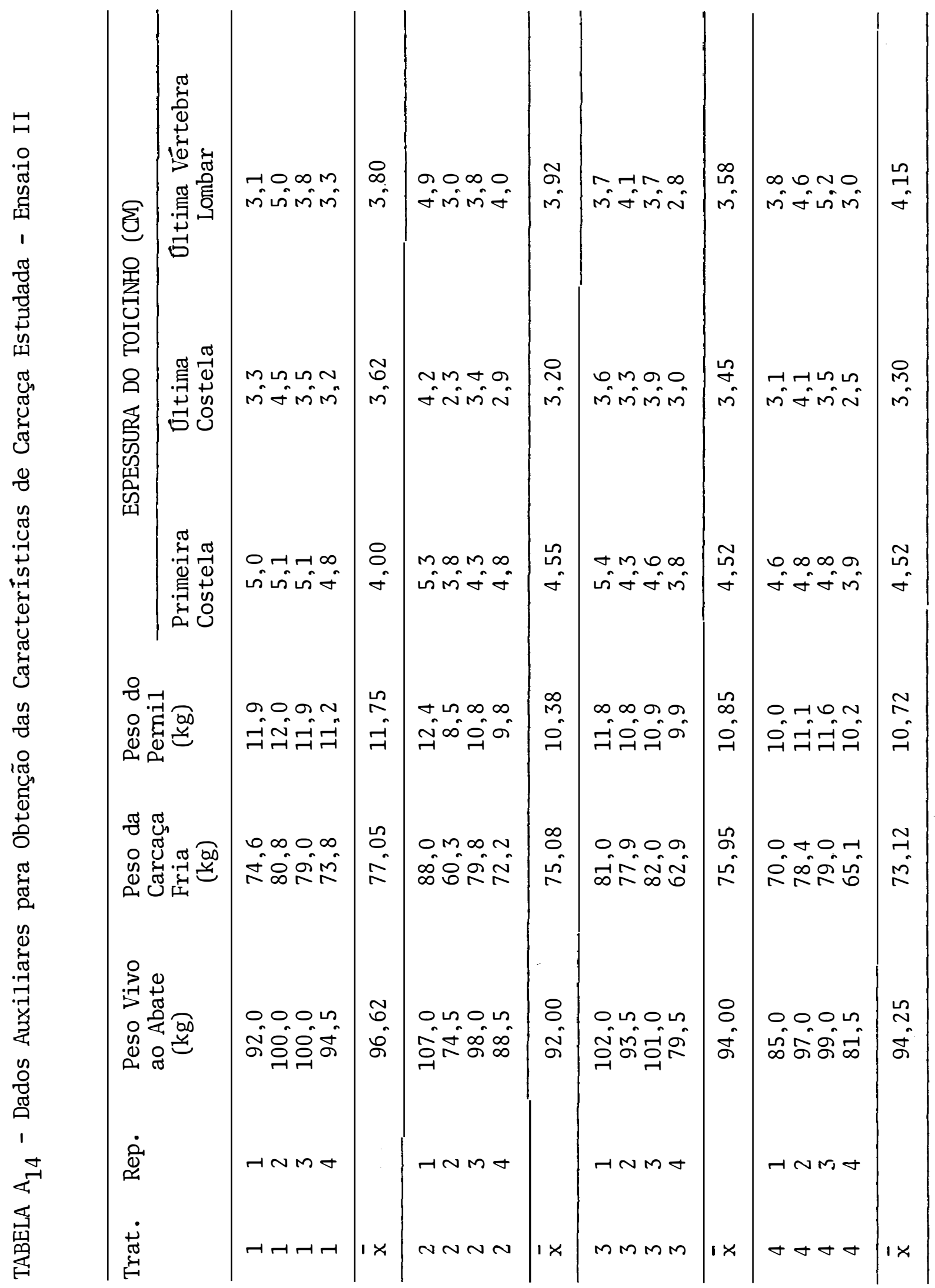




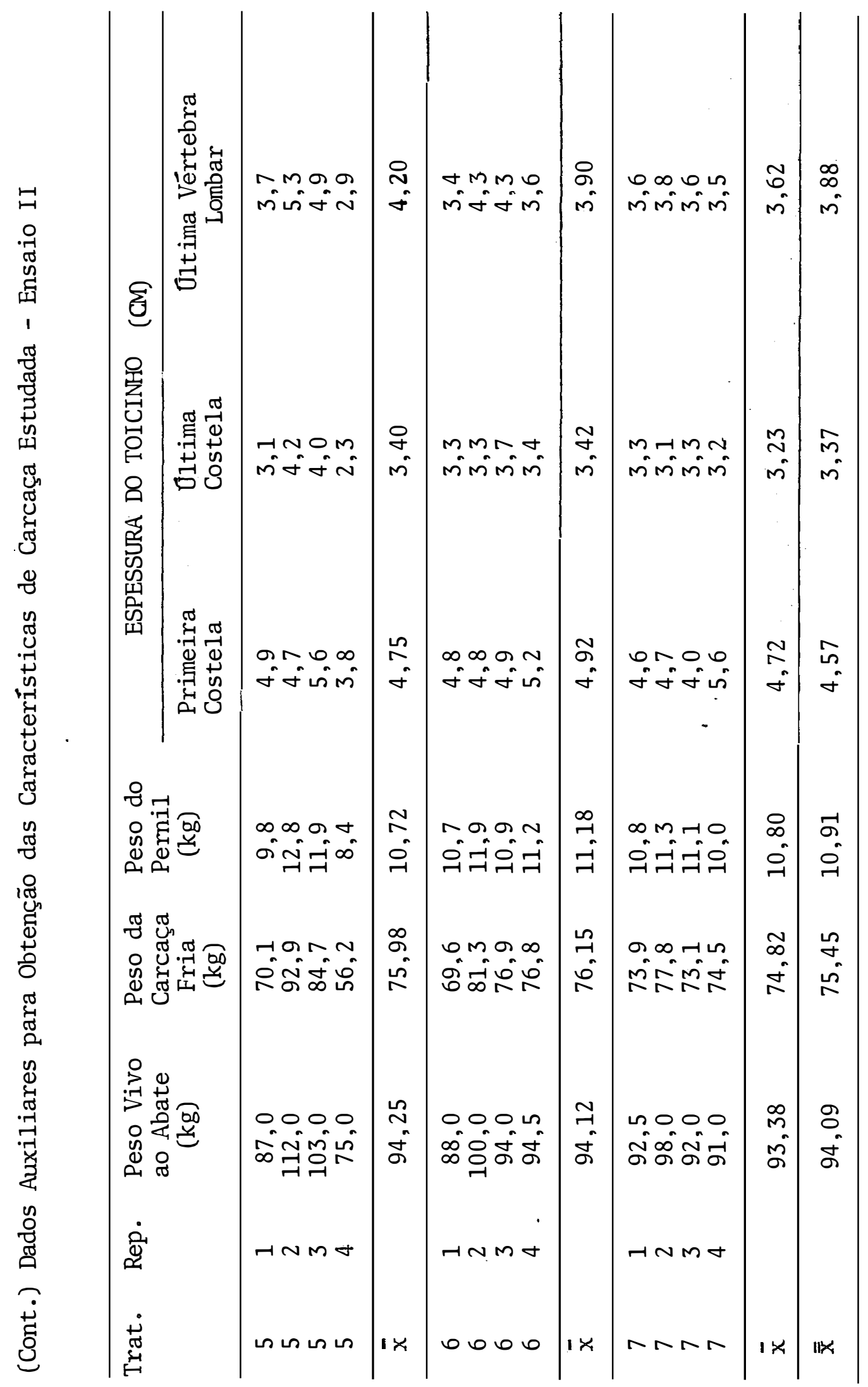

